Ruling the

Referendum? vut

European Integration Challenged by Direst Democracy

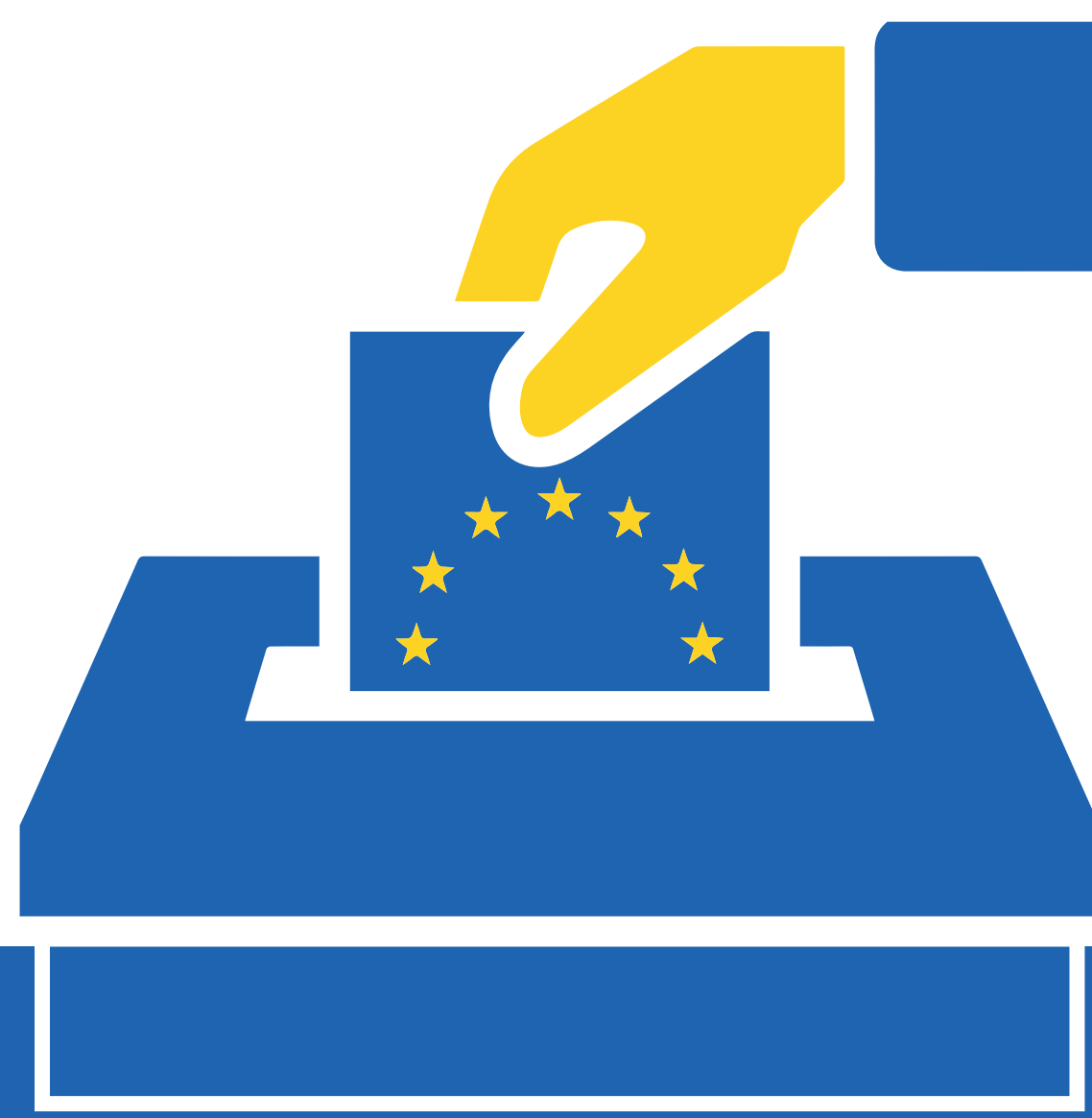

Joost van den Akker 



\section{Ruling the Referendum?}

European Integration Challenged by Direct Democracy 


\section{Graduation Committee}

Chair

Secretary

Supervisor

Co-supervisors

Members

Referent
Prof. Dr. T.A.J. Toonen, University of Twente

Prof. Dr. T.A.J. Toonen, University of Twente

Prof. Dr. C.W.A.M. Aarts, University of Twente

Dr. H. van der Kolk, University of Twente

Dr. H.J.L.M. van de Luijtgaarden, Zuyd University of Applied Sciences

Prof. Dr. S.A.H. Denters, University of Twente

Prof. Mr. Dr. M.A. Heldeweg, University of Twente

Prof. Dr. F. Hendriks, Tilburg University

Prof. Dr. B. Vis, Utrecht University

Dr. M. Rosema, University of Twente

\footnotetext{
$\widehat{N \mathcal{W}} \mid \begin{aligned} & \begin{array}{l}\text { Netherlands Organisation } \\ \text { for Scientific Research }\end{array} \\ & \text { for }\end{aligned}$
}

This research was supported by the Netherlands Organisation for Scientific Research (NWO) under project number: 023.005 .098

Cover design and print by Ipskamp Printing, Enschede

Manuscript edited by Russ Kent, Zuyd University of Applied Sciences

ISBN

$978-90-365-4579-2$

DOI

$10.3990 / 1.9789036545792$

(c) Joost van den Akker, 2018

All rights reserved. No part of this book or (online) appendices may be reproduced or transmitted, in any form or by any means, electronic or mechanical, including photocopying, microfilming, and recording, or by any information storage or retrieval system, without the prior written consent by the author. 


\title{
RULING THE REFERENDUM?
}

\section{EUROPEAN INTEGRATION CHALLENGED BY DIRECT DEMOCRACY}

\author{
DISSERTATION
}

\author{
to obtain \\ the degree of doctor at the University of Twente, \\ on the authority of the rector magnificus \\ prof. dr. T.T.M. Palstra,
}

on account of the decision of the graduation committee,

to be publicly defended

on Wednesday 4 July 2018 at 12.45 hrs

by

\author{
Joost Pieter van den Akker \\ born on 6 October 1984 \\ in Rotterdam, the Netherlands
}


This dissertation has been approved by

Prof. Dr. C.W.A.M. Aarts, University of Twente

Dr. H. van der Kolk, University of Twente

Dr. H.J.L.M. van de Luijtgaarden, Zuyd University of Applied Sciences 


\section{Acknowledgements}

Writing a dissertation is a search for yourself. As in Franz Schubert's song Der Wegweiser', the researcher avoids roads which other travelers used to go, but searches out the hidden pathways. Sometimes through snowy mountain tops, sometimes traveling a street from which no one ever returned. You do not know when and where to end. Which desire drives the researcher into the wilderness, wandering ever further without rest? Probably to find out the truth in a world of humans, nature and science. Science also reflects the truth of its time. The last years at the University of Twente comprise a period in which the nationwide referendum has been introduced in the Netherlands and is -almost- withdrawn.

After having graduated from Maastricht University, I was grasped by the challenge to do more fundamental research. Even before his research group Law on Europe was officially established within Zuyd University of Applied Sciences, Eric van de Luijtgaarden invited me to take part in research discussions, to brainstorm about a suitable topic and to look for a potential supervisor. After some time, governmental action in EU-related referendums turned out to be the niche topic. In May 2012, Kees Aarts and Henk van der Kolk entrusted me to start as one of their PhD researchers at the University of Twente. During our first acquaintance, Kees envisaged that my subject of EU-related referendums would gain significance. He was right: the referendum became highly topical over the last five years. I had barely started my PhD research in autumn 2012, when in January 2013 former British Prime Minister David Cameron announced that the United Kingdom would hold an 'in or out' referendum on EU membership before the end 2017. The rest is history, still history in the making. How will Great Britain be able to rule the referendum outcome?

I am most grateful to Kees, Henk and Eric for their outstanding guidance, always warm advice, and steady, patient and confident support during almost six years of supervision. Despite the distance to Enschede (or even Groningen), it was possible to arrange lengthy and well-prepared meetings, regularly after which I returned to Maastricht, always energized and with a lot of homework. Kees has been extremely stimulating in composing this thesis as is now, by suggesting how to build up the level of research and writing and to design the different theoretical frameworks into one coherent monograph. Henk has been very helpful in learning me the skills of well-structured and tight academic writing, modelling of causal inferences and very constructive and critical feedback on tables and figures. I have very much appreciated our intense discussions on draft chapters and papers.

Eric enriched the discussions with the legal perspectives of this thesis. Though to count on Eric's enduring support how to maintain the balance between jobs in Twente and Limburg and between public and private life was at least as valuable. In this respect, Eric has been a true mentor. Fortunately, my research activities were not spatially limited to Twente, but also embedded in the meetings of his research group. I would like to sincerely thank the members 
for their feedback and thinking along.

When I wondered how to proceed after one year of collecting data and presenting my first conference papers, Kees suggested to explore the set-theoretic method of Qualitative Comparative Analysis (OCA). The world of OCA proved to be a research journey in itself. I would like to thank Benoît Rihoux, Carsten O. Schneider, Eva Thomann and Joachim Blatter for their very useful methodological trainings, valuable feedback and academic discussions during several conference workshops, ECPR summer and winter schools and joint sessions. It turned out during the ECPR summer school in Ljubljana in 2014 on OCA, that PhD fellow Koen van der Krieken and I were both studying referendums, while applying this same method. Ever since then we have taken the opportunity to meet occasionally, to exchange views and to explore the latest state of OCA affairs. Thanks a lot for the engaging discussions and friendship on the referendum issue. Furthermore I want to acknowledge some other colleagues of the evolving referendum research community for their valuable comments and discussions during several occasions: Martin Rosema, Ramses Wessel, Frank Hendriks, Kristof Jacobs and Charlotte Wagenaar.

The bright and spacious atmosphere at the UT campus provided a stable and comfortable research climate in which I immediately felt at home to study for several days. Particularly I thank Annette van der Tuuk, Manon Jannink-van het Reve and Seeta Autar for their very warm assistance to find my way on the campus, their practical support, and pleasant talks over lunch and coffee breaks. Despite being able to be there only once every few weeks, the colleagues at the Public Administration department gave me the opportunity to become part of the research community. A special word of thanks to the (former) PhD fellows Kira Killermann, Ann-Kristin Kölln and Wouter Jans for the fine and decent exchange of views and feedback, particularly at informal occasions. I very much enjoyed participating in the academic IoG lunch meetings, the NIG conferences, PhD training courses and the social events. It was very much worth it driving 250 kilometres to Enschede. In the meantime I have encountered road works (Baustellen) along the entire $A_{31}$ between Bottrop and Gronau (fortunately still without paying PKW-Maut).

I am very thankful to Lies de Regt and Jeanette Oostijen (as head of the European Studies department and as dean of the Faculty of International Business and Communication in Maastricht), who stimulated and supported me to explore my research ambitions and capabilities. In this respect, I am very grateful for the financial support from Zuyd University of Applied Sciences, and for the research grant from the Netherlands Organisation for Scientific Research, which was awarded by former Minister of Education, Culture and Science, Jet Bussemaker in 2015. Many thanks indeed to Russ Kent for editing the manuscript and Ipskamp Printing for the layout and printing of the book. I also thank my dear colleagues in Limburg, at the European Studies department and the students, for their interest in my research project and for their understanding for the time that it consumed.

Intensive research and writing require relaxation every now and then, time to spend with 
close friends and relatives, and a healthy condition. I have enjoyed it very much to be able to continue making music with friends of the University Orchestra Maastricht. From last year onwards, rowing at or running along the Meuse in the early morning definitely turned out to be the ultimate start of the day. Thanks to my rowing mates of the Maastrichtsche Watersport club for the nice trainings and talks afterwards.

Finally, I would like to express my warmest and deepest gratitude to my parents and to my paranymphs: my sister Sophie van den Akker and my dear friend Floor Vermeulen. I could always count on your advice and warm encouraging and practical support, which are invaluable and indispensable in order to successfully complete this dissertation.

Maastricht, June 2018 Joost van den Akker 


\section{Contents}

List of Tables 13

List of Figures $\quad 15$

$\begin{array}{ll}\text { 1. Introduction } & 17\end{array}$

1.1 Specifying the research question 18

$\begin{array}{ll}1.2 & \text { The population of cases } \\ & 19\end{array}$

1.3 Argument and outline of the book 23

1.4 Scope and limitations 26

2. Representative Government, Referendums and the EU 29

2.1 Referendums and democratic theory 29

2.2 The emergence of referendums in European democracies 32

2.2.1 Empowerment of (authoritarian) rule 32

$\begin{array}{ll}\text { 2.2.2 Independence } & 33\end{array}$

2.2.3 Direct citizen participation $\quad 34$

2.2.4 Transfer of sovereignty to the EU 35

2.3 The institutional context 36

$\begin{array}{ll}\text { 2.3.1 Mandatory referendums } & 37\end{array}$

2.3.2 Optional referendums 38

2.3.3 Legal impact of the result: consultative or binding 39

2.4 The political context 39

2.4.1 Partisan calculus: politically motivated to call 40

2.4.2 Appropriateness: politically compelled to call 42

2.4.3 Offensive or defensive pledges? 43

$\begin{array}{ll}2.4 .4 & \text { Conclusion }\end{array} 44$ 
2.5 Voting behaviour in EU-related referendums 44

2.5.1 Issue voting and EU attitudes $\quad 45$

2.5.2 Elite cues 46

2.5.3 Evaluating the government 48

$\begin{array}{ll}2.5 .4 & \text { Conclusion }\end{array}$

$\begin{array}{lll}2.6 & \text { Conclusion } & 49\end{array}$

3. When are EU-related referendums held?

3.1 The legal contexts of referendums 53

3.2 Mandatory referendum regimes 54

3.3 Optional referendum regimes 59

$\begin{array}{ll}\text { 3.3.1 Options governments have } & 59\end{array}$

3.3.2 Options parliaments have 59

$\begin{array}{lll}3.3 .3 & \text { Options citizens have } & 60\end{array}$

3.4 The practice of EU-related referendums 61

3.4.1 Mandatory EU referendums $\quad 63$

$\begin{array}{ll}\text { 3.4.2 Optional EU referendums } & 65\end{array}$

3.5 Referendums that never occurred $\quad 71$

$\begin{array}{lll}\text { 3.5.1 } & \text { Referendum avoidance } & 72\end{array}$

$\begin{array}{ll}\text { 3.5.2 Anti-referendum advises } & 73\end{array}$

$\begin{array}{lll}\text { 3.5.3 Anti-referendum rulings } & 73\end{array}$

$\begin{array}{lll}3.6 & \text { Conclusion } & 74\end{array}$

$\begin{array}{ll}\text { 4. When do governments win EU-related referendums? } & 77\end{array}$

4.1 What may contribute to government victory? $\quad 77$

4.1.1 Issue voting and EU attitudes $\quad 78$

$\begin{array}{lll}\text { 4.1.2 } & \text { Elite consensus } & 78\end{array}$ 
4.1.3 Evaluating the government: incumbent support and recent elections

$\begin{array}{ll}\text { 4.1.4 Offensive referendum strategies } & 80\end{array}$

4.1.5 Economic circumstances and net redistribution gains 81

4.1.6 Types of EU referendums 83

4.1.7 Combinations of factors 83

$\begin{array}{lll}4.2 & \text { Data and methods } & 84\end{array}$

$\begin{array}{ll}\text { 4.2.1 } & \text { Operationalisation } \\ & 85\end{array}$

$\begin{array}{lll}\text { 4.2.2 } & \text { Bivariate analysis } & 86\end{array}$

4.2.3 Method: fuzzy-set Qualitative Comparative Analysis 89

$\begin{array}{lll}4.3 & \text { Results } & 90\end{array}$

$\begin{array}{lll}4.3 .1 & \text { Sufficient conditions } & 91\end{array}$

$\begin{array}{lll}\text { 4.3.2 Necessary conditions } & 95\end{array}$

$\begin{array}{lll}\text { 4.3.3 } & \text { Defeated referendums } & 97\end{array}$

$\begin{array}{lll}4.4 & \text { Theory evaluation } & 99\end{array}$

$\begin{array}{lll}4.5 & \text { Conclusion } & 100\end{array}$

$\begin{array}{ll}\text { 5. Why are some cases deviant? } & 105\end{array}$

$\begin{array}{lll}5.1 & \text { Comparative Process Tracing } & 105\end{array}$

$\begin{array}{lll}5.2 & \text { Types of cases in post-OCA analysis } & 106\end{array}$

$\begin{array}{lll}\text { 5.2.1 Typical cases } & 106\end{array}$

$\begin{array}{ll}\text { 5.2.2 Deviant cases of consistency in degree } & 107\end{array}$

$\begin{array}{ll}\text { 5.2.3 Deviant cases of consistency in kind } & 107\end{array}$

$\begin{array}{lll}\text { 5.2.4 Deviant cases for coverage } & 107\end{array}$

$\begin{array}{lll}\text { 5.2.5 Irrelevant cases } & 108\end{array}$

$\begin{array}{lll}5.3 & \text { Tracing types of cases } & 108\end{array}$

$\begin{array}{lll}\text { 5.3.1 Typical cases } & 111\end{array}$ 
5.3.2 Deviant cases coverage

$\begin{array}{lll}5.4 & \text { Deviant case analysis } & 114\end{array}$

$\begin{array}{lll}\text { 5.4.1 Ireland 2009: economic recovery } & 114\end{array}$

5.4.2 Denmark 2014 and Denmark 2000: loss of sovereignty 116

$\begin{array}{lll}5.5 & \text { Conclusion } & 117\end{array}$

6. How do governments deal with inconvenient EU referendum outcomes?

6.1 Design: how preferences and constraints shape strategies 123

6.1.1 What can governments do after defeat? 123

6.1.2 What make governments do what they did? 124

6.2 Accepting the result: 'the people have spoken' 127

$\begin{array}{ll}\text { 6.2.1 } & \text { Adaptation after failed membership } \\ & 127\end{array}$

6.2.2 Renegotiation after the failed Constitutional Treaty 130

6.2.3 Status quo after a 'No' to the Euro 133

6.3 Interpreting the result: No means what? $\quad 135$

$\begin{array}{lll}\text { 6.3.1 UK 2016: 'Brexit means Brexit'? } & 135\end{array}$

6.3.2 The Swiss, Danish and Dutch referendums 2014-2016 137

6.4 Circumventing the result: railroading to a Yes? 141

6.4.1 Partial defection: a domestic problem 142

6.4.2 A domestic solution? 143

6.5 Neglecting the result: 'it does not matter after all' $\quad 148$

$\begin{array}{lll}\text { 6.6 Overview of the analysis } & 148\end{array}$

$\begin{array}{lll}6.7 & \text { Conclusion } & 150\end{array}$

$\begin{array}{ll}\text { 7. Conclusion and discussion } & 155\end{array}$

7.1 EU-related referendums in historical perspective $\quad 156$

$\begin{array}{lll}7.2 & \text { Calling referendums } & 156\end{array}$ 
$\begin{array}{lll}7 \cdot 3 & \text { Winning referendums } & 158\end{array}$

7.4 Dealing with inconvenient referendum results $\quad 160$

$\begin{array}{llr}7.5 & \text { Implications } & 162\end{array}$

$\begin{array}{lll}7.6 & \text { Limitations and future research } & 164\end{array}$

$\begin{array}{ll}\text { References } & 165\end{array}$

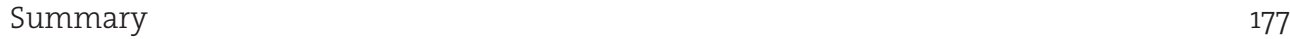

$\begin{array}{ll}\text { Samenvatting } & 183\end{array}$

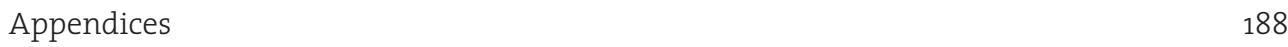

$\begin{array}{ll}\text { Appendix Ch. 3: Constitutional and legal provisions } & 188\end{array}$

$\begin{array}{ll}\text { Appendix Ch. 4: Supplementary tables } & 209\end{array}$

Appendix Ch. 5: Uniquely typical cases 223

$\begin{array}{ll}\text { Biography } & 225\end{array}$ 


\section{List of Tables}

Table 1.1

Table 3.1

Table 3.2

Table 3.3

Table 4.1

Table 4.2

Table 4.3

Table 4.4

Table 5.1

Table 5.2

Table 5.3

Table 5.4

Table 6.1

Table 6.2
Referendums on European integration 1972-2016

21

Potential of EU-related referendums in European democracies

Practice of EU-related referendums in European democracies

Overriding reasons per actor to trigger EU-related referendums (specified per case)

Measurement and calibration of conditions

Sufficiency analyses for successful referendum outcomes 'OUT'

Sufficiency analyses for unsuccessful referendum outcomes 'out'

Types of cases classified by the conditions and the outcome in fuzzy sets

Types of cases in Membership, Treaty and Policy referendums

Deviant cases coverage

Membership scores of cases in the same truth table row as the deviant cases coverage

Defeated referendums on European integration 1972-2016

Constraints at the domestic and European level of defeated

57

58

62

85

87

97

114
Bivariate analysis of government victory referendums

Raw data

209

Fuzzy data

212

214

215

217

219

Table A4.6 Simplifying assumptions for analysis of successful referendum outcomes 'OUT' 
Table A4.7 Simplifying assumptions for analysis of unsuccessful referendum 220 outcomes 'out'

Table A4.8 Analysis of necessity for successful outcome 'OUT' and unsuccessful outcome 'out'

Table A5.1 Uniquely typical cases: Membership referendums

Table A5.2 Uniquely typical cases: Treaty referendums 223

Table A5.3 Uniquely typical cases: Policy referendums 


\section{List of Figures}

Figure 1.1 EU-related referendum outcomes 1972-2016 20

Figure 2.1 Nationwide referendum institutions in Europe 1790-2017 $\quad 31$

Figure 2.2 Actors to trigger EU-related referendums 37

Figure $3.1 \quad$ Overriding reasons per actor to trigger EU-related referendums 62

Figure $3.2 \quad$ Practice of mandatory EU referendums in countries providing for $\quad 64$ them

Figure 3.3 Practice of optional EU referendums in countries providing for $\quad 67$ them

Figure 4.1 Conditions and propositions contributing to government $\quad 84$ victory

Figure 4.2 Sufficiency analyses for successful referendum outcomes 93

Figure 4.3 Offensive referendum strategy as a necessary condition for $\quad 96$

Figure 6.1 Government strategies dealing with inconvenient referendum $\quad 126$ outcomes

Figure S.1 Map of EU-related referendums 1972-2016, indicating type and 182 number 



\section{Introduction}

Referendums on European integration play a prominent role in the decision-making processes in current European democracies. European integration started as an elite-driven top-down process in the 1950 s without direct citizen participation. Jean Monnet "thought it wrong to consult the peoples of Europe about the structure of a Community of which they had no practical experience" (Monnet 1978: 367). EU-related referendums, however, have become increasingly important, especially over the last 45 years.

The expanding European integration process has increasingly faced concerns on the legitimacy of supranationalised decision-making among member states. The widening and deepening of the European Communities (EC) and later the European Union (EU) comprised far-reaching decisions on membership of the community and on subsequent treaty changes. To meet these concerns at the national level, the desire for direct democratic tools to legitimise these transfers has increased accordingly. The idea was that if citizens, constituting the highest sovereign authority of the state, directly expressed their support for the issue it would be better legitimised compared to representative decision-making. It is argued that a popular majority outweighs the political majority in parliament, also because it is detached of partisan considerations (Auer 2016: 402). Referendums ${ }^{1}$ have been frequently held in Europe since the $20^{\text {th }}$ century, including more and more issues on European matters. The expansion of EU-decision making has been accompanied by the extended legal possibilities across many European states to enable referendums on EU-related issues. The enlargement rounds of the European Communities started in an era in which direct citizen participation in the democratic decision-making process became an imminent issue on the political agenda.

Moreover, the expanding body of EU-legislation triggered member states to hold referendums more frequently to legitimise these European laws according to their constitutional and legal regimes. Particularly on constitutional issues related to a transfer of sovereignty, the changing tides and norms of democratic legitimation of this integration process in combination with a growing disenchantment of citizens with the EU resulted in an increasing demand for and use of referendums. "Referendums on European integration issues are amongst the most common in the Western world and the EU and its treaties, currency, policies, and membership are among the most voted on issues in the world" (Schuck and De Vreese 2015: 151-152). More than 60 referendums have been held since the 1970s, of which more than three-quarters since the establishment of the EU by the Maastricht Treaty in 1992. Where referendums on EC or EU membership were organized throughout, referendums on specific policy issues were held more recently and more frequently over the last 25 years. Hence, the extended referendum possibilities and EU decision making make referendums related to the EU an important subject to investigate.

Despite their increasing prominence, these referendums have hardly been studied with regard to the question why governments sometimes win or lose them. The role that 
governments play in this decision-making process has received comparatively little attention within the increasing amount of research on EU-related referendums. Consequently, the study of governmental actors in EU-related referendums is still underdeveloped. Researchers have hardly developed predictive models which forecast the winners, and opinion polls have not always been able to correctly predict the outcome. This suggests that alternative methods should be explored to find out which side wins the referendum and why (Ovortrup 2018b).

The central position that governments have in decision-making in EU issues, makes that they are held responsible and accountable for the success or failure of the EU's decisions at referendums. If the government's desired EU policies are not expressly supported by its citizens, the government is expected to (re)act. Governments pursue the objective of winning votes during the referendum and the next elections. Until a decade ago, governments used to win these referendums and could use these outcomes in order to consolidate their position. However, particularly since 2014, the Brussels establishment and national governments have faced a serious backlash, as British, Danish, Dutch, and Swiss majorities dismissed their government's EU policy. The recent popular rejections prominently demonstrate the turn from permissive consensus to constraining dissensus on the EU (Hooghe and Marks 2009).

\subsection{Specifying the research question}

This study assesses the puzzle why governments win or lose EU-related referendums. The Spanish referendum on the EU's Constitutional Treaty resulted in a victory for the government, while the subsequent French and Dutch votes on the issue resulted in a devastating defeat. How was this possible? What overarching factors can be identified? By finding out when governments win or defeat these referendums, policy-makers can better anticipate the course of future direct democratic decision-making processes.

So far, EU-related referendum studies have mainly dealt with the motives behind the voter's rational choice to support, oppose or abstain the issue at stake (Albi 2005, Closa 2013, De Vreese and Semetko 2004, Franklin et al. 1995, Hobolt 2009, Hollander 2016, Jenssen et al. 1998, Massüger and Kuoni 2011, Mendez et al. 2014, Ovortrup 2016). However, this literature has not particularly looked at the role of governments. Most importantly it is not known yet why governments sometimes win or lose these referendums. What importance can for instance be attributed to the state of the economy, or the degree of elite consensus on the issue? Moreover, it is not clear if, how and why national governments in the EU (in their respective constitutional contexts) have initiated such referendums (or not). For instance, were politically mediating motives the overriding factor or did domino effects between countries play a dominant role? Finally, it has hardly been researched how governments coped with (particularly inconvenient) referendum outcomes. What happens if a country suddenly seems unable to ratify a comprehensive multilateral treaty or if a country is not to become or remain an EU member state? Therefore, the main research question this study aims to answer is 
Under which conditions do governments win EU-related referendums?

This main question is accompanied by two related questions: why do EU-related referendums take place and, how do governments deal with inconvenient referendum outcomes? In order to answer these questions, it is first necessary to provide an overview and analysis in which countries EU-related referendums can be held, have been held, on what issues, and for which reasons they were triggered. This includes unravelling the various forms and procedures and analysing how referendums are institutionalised. It also requires discussing the scope of EU-related referendums and how these fit in representative democracy. Next to this conceptualisation, it also necessitates a theoretical framework that explains why and how governments win or lose referendums, and how they cope with the inconvenient outcomes.

\subsection{The population of cases}

This study focuses on national referendums in European democratic states which are directly related to the integration process of the European Union. EU-related referendums are defined as 'official popular votes or plebiscites on a particular aspect of European integration in a nation state' (Wimmel 2014: 35). . This definition sets the scope of EU-related referendums, which form the units of analysis in this study. Hence nationwide referendums directly related to the European integration process fall within this scope. Three types of EU-related referendums are distinguished: membership referendums, treaty referendums and policy referendums (Hobolt 2009, Mendez et al. 2014). Membership referendums concern the accession to, application for or withdrawal from the EU or the EEA. Treaty referendums deal with the ratification of multilateral comprehensive EU treaties. The scope of this category is confined, as e.g. bilateral agreements between the EU and a state are considered issue specific policy referendums (and not treaty referendums). ${ }^{3}$ Also popular votes on the participation in the Euro or the Schengen area classify as policy referendums. This typology is relevant for this study because the referendum type distinguishes the nature of the question that is at stake. It will be assessed further on whether the type of referendum matters in relation to the factors contributing to a successful referendum outcome for the government.

The study uses an original dataset comprising all EU-related referendums in European democratic countries between 1972 and 2016, the period between the first and at the time of writing last EU-related referendums. Therefore, also referendums in non-EU member states are are included, such as in Liechtenstein, Norway and Switzerland. Although many referendums in Europe are indirectly linked to the European Union, this study does not include referendums on (subsequent) national implementation measures deriving from EU regulations, decisions or directives; or referendums on national issues with potential impact on the EU's integration process. For instance, the 2014 Scottish independence referendum is not directly related to EU policy but could have (had) huge consequences for the Scottish, and British relationship with the EU.

Table 1 presents an overview of the 61 referendums across 28 countries. In 46 
referendums the government won; while it lost the 15 other cases. In recent years it has been commonly assumed that voters reject referendum proposals on EU issues. However, in 42 of the won cases, the successful outcome for the government also reflects a pro-EU outcome. Voting margins in favour of the EU range from 94 percent in case of Slovakia's accession referendum in 2003 to 98 percent against the EU in case of Hungary's referendum on the resettlement of migrants in 2016 (which turned out to be invalid due to the low turnout). The four other cases which the government won were in fact a vote against the EU.4

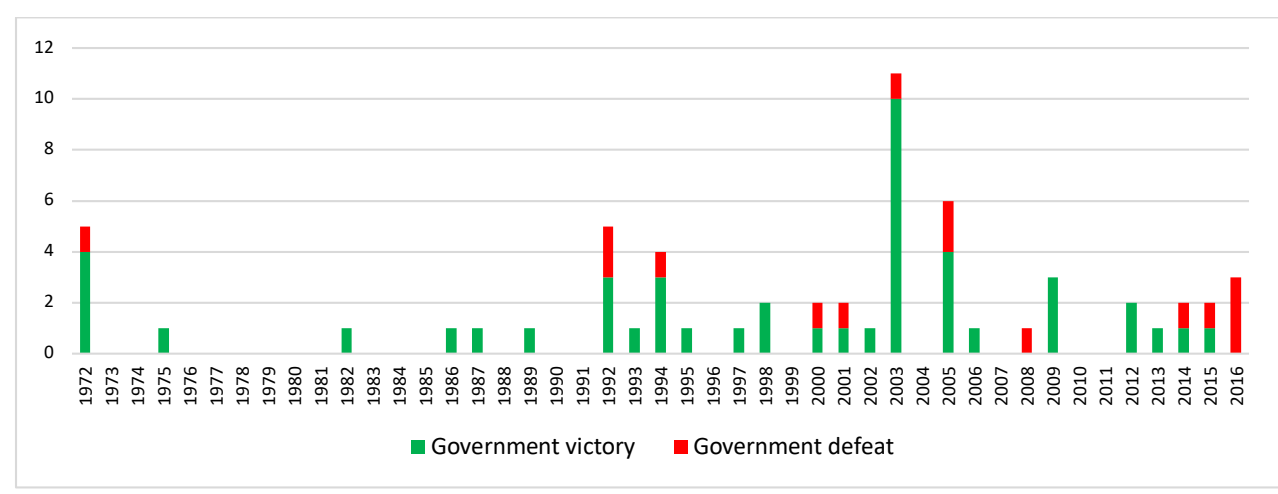

Figure 1.1. EU-related referendum outcomes 1972-2016 ( $\mathrm{n}=61)$.

As one can observe in Figure 1.1, EU-related referendums have taken place since 1972 but only quite frequently from 1992 onwards, when the debate on the Maastricht Treaty marked the end of the 'permissive consensus' on Europe (cf. Eichenberg and Dalton 2007). The support for the government in these referendums has declined over time. The turn into a 'constraining dissensus' on European integration after 1992 became clearly apparent in the 2000s, when the government lost more referendums (11 out of 37; 30\%), compared to the referendums in the $20^{\text {th }}$ century ( 4 out of $24 ; 16 \%$ ). "From the 1990 on onwards, particularly after the signing of the Maastricht Treaty (1992), Europe dramatically increased its supranational powers, in economic as well as non-economic policy areas" (Van Elsas and Van der Brug 2015: 195). Consequently, the debates shifted accordingly to sovereignty issues on monetary, foreign and migration policy. Did these sovereignty issues change the nature of EU-related referendums? On the one hand, probably some issues were more contested than those before. On the other hand, both before and after 1992, all EU-related referendums dealt with membership, treaty and policy issues. So, it seems that the context of these referendums did not change substantially after 1992 compared to the preceding decades.

As the southern European countries Greece, Portugal and Spain became democracies in the 1980s, and the Central and Eastern European Countries in the 1990s, the relevant legislation and referendums in these countries has been considered only during the democratic eras. Hence the time and scope of this study are defined by (the potential of) referendums on EU matters from 1972 onwards in Western Europe and from 1989 onwards in 
Central and Eastern European states.

Instead of doing some case studies, analysing the full population of cases allows better to unravel the mechanism between the conditions and the outcome. This study follows an inductive approach by doing a comparative, historical-institutional-legal analysis of these cases in order to unfold causal cross-country patterns to success for the government. As the full population of cases is discussed, there is no need to apply statistical methods. There are neither grand theories or clear expectations to test based on previous research, which allow for a deductive approach. Conceived as a comparative study, it explores socio-economic and political conditions of variation across European democratic countries and examines the government's success.

Table 1.1. Referendums on European integration 1972-2016.

\begin{tabular}{|c|c|c|c|c|c|c|c|}
\hline Year & Country & Case & Subject & Type & $\begin{array}{l}\text { Turn- } \\
\text { out }\end{array}$ & Yes & $\begin{array}{l}\text { Govern- } \\
\text { ment win } \\
\text { defeat }\end{array}$ \\
\hline 1972 & Denmark & DEN1972 & EC Membership & $\begin{array}{l}\text { Member- } \\
\text { ship }\end{array}$ & 90.4 & 63.4 & Win \\
\hline 1972 & Ireland & IRL1972 & EC Membership & $\begin{array}{l}\text { Member- } \\
\text { ship }\end{array}$ & 70.3 & 83.1 & Win \\
\hline 1972 & Norway & NOR1972 & EC Membership & $\begin{array}{l}\text { Member- } \\
\text { ship }\end{array}$ & 79.2 & 46.5 & Defeat \\
\hline 1972 & France & FRA1972 & Enlargement of EC & Policy & 60.2 & 68.3 & Win \\
\hline 1972 & Switzerland & SWI1972 & EC-EFTA Treaty & Policy & 52 & 72.5 & Win \\
\hline 1975 & Great Britain & GBR1975 & EC Membership & $\begin{array}{l}\text { Member- } \\
\text { ship }\end{array}$ & 64.5 & 67.2 & Win \\
\hline 1982 & Greenland & GRE1982 & EC Membership & $\begin{array}{l}\text { Member- } \\
\text { ship }\end{array}$ & 74.9 & 53 & Win \\
\hline 1986 & Denmark & DEN1986 & $\begin{array}{l}\text { Single European } \\
\text { Act }\end{array}$ & Treaty & 75.4 & 56.2 & Win \\
\hline 1987 & Ireland & IRL1987 & $\begin{array}{l}\text { Single European } \\
\text { Act }\end{array}$ & Treaty & 43.9 & 69.9 & Win \\
\hline 1989 & Italy & ITA1989 & $\begin{array}{l}\text { Future European } \\
\text { Constitution }\end{array}$ & Policy & 81 & 88.1 & Win \\
\hline 1992 & Liechtenstein & LIE1992 & EEA Accession & $\begin{array}{l}\text { Member- } \\
\text { ship }\end{array}$ & 87 & 55.8 & Win \\
\hline 1992 & Switzerland & SWI1992 & EEA Accession & $\begin{array}{l}\text { Member- } \\
\text { ship }\end{array}$ & 78 & 49.7 & Defeat \\
\hline 1992 & Denmark & DEN1992 & Maastricht Treaty & Treaty & 83.1 & $49 \cdot 3$ & Defeat \\
\hline 1992 & France & FRA1992 & Maastricht Treaty & Treaty & 69.8 & 51.1 & Win \\
\hline 1992 & Ireland & IRL1992 & Maastricht Treaty & Treaty & $57 \cdot 3$ & 69.1 & Win \\
\hline 1993 & Denmark & DEN1993 & Maastricht Treaty & Treaty & 86.5 & 56.7 & Win \\
\hline
\end{tabular}




\begin{tabular}{|c|c|c|c|c|c|c|c|}
\hline 1994 & Austria & AUS1994 & EU Membership & $\begin{array}{l}\text { Member- } \\
\text { ship }\end{array}$ & 82.3 & 66.6 & Win \\
\hline 1994 & Finland & FIN1994 & EU Membership & $\begin{array}{l}\text { Member- } \\
\text { ship }\end{array}$ & 70.8 & 56.9 & Win \\
\hline 1994 & Norway & NOR1994 & EU Membership & $\begin{array}{l}\text { Member- } \\
\text { ship }\end{array}$ & 89 & 47.7 & Defeat \\
\hline 1994 & Sweden & SWE1994 & EU Membership & $\begin{array}{l}\text { Member- } \\
\text { ship }\end{array}$ & 83.3 & 52.3 & Win \\
\hline 1995 & Liechtenstein & LIE1995 & EEA Accession & $\begin{array}{l}\text { Member- } \\
\text { ship }\end{array}$ & 82 & 55.9 & Win \\
\hline 1997 & Switzerland & SWI1997 & EU Candidature & $\begin{array}{l}\text { Member- } \\
\text { ship }\end{array}$ & 35 & 25.9 & Win \\
\hline 1998 & Denmark & DEN1998 & $\begin{array}{l}\text { Treaty of } \\
\text { Amsterdam }\end{array}$ & Treaty & 76 & 55.1 & Win \\
\hline 1998 & Ireland & IRL1998 & $\begin{array}{l}\text { Treaty of Amster- } \\
\text { dam }\end{array}$ & Treaty & 56 & 61.7 & Win \\
\hline 2000 & Denmark & DEN2OOO & EMU Membership & Policy & 88 & 46.9 & Defeat \\
\hline 2000 & Switzerland & SWI2000 & $\begin{array}{l}\text { Bilateral agree- } \\
\text { ments with EU }\end{array}$ & Policy & 48 & 67.2 & Win \\
\hline 2001 & Switzerland & SWI2OO1 & EU Candidature & $\begin{array}{l}\text { Member- } \\
\text { ship }\end{array}$ & 55 & 23.2 & Win \\
\hline 2001 & Ireland & IRL2OO1 & Nice Treaty & Treaty & 35 & 46.1 & Defeat \\
\hline 2002 & Ireland & IRL2OO2 & Nice Treaty & Treaty & 49 & 62.9 & Win \\
\hline 2003 & $\begin{array}{l}\text { Czech } \\
\text { Republic }\end{array}$ & CZE2OO3 & EU Membership & $\begin{array}{l}\text { Member- } \\
\text { ship }\end{array}$ & 55 & $77 \cdot 3$ & Win \\
\hline 2003 & Estonia & EST2OO3 & EU Membership & $\begin{array}{l}\text { Member- } \\
\text { ship }\end{array}$ & 64 & 66.8 & Win \\
\hline 2003 & Hungary & HUN2OO3 & EU Membership & $\begin{array}{l}\text { Member- } \\
\text { ship }\end{array}$ & 46 & 83.7 & Win \\
\hline 2003 & Latvia & LAT2003 & EU Membership & $\begin{array}{l}\text { Member- } \\
\text { ship }\end{array}$ & 73 & 67 & Win \\
\hline 2003 & Lithuania & LIT2003 & EU Membership & $\begin{array}{l}\text { Member- } \\
\text { ship }\end{array}$ & 63 & 91.1 & Win \\
\hline 2003 & Malta & MAL2OO3 & EU Membership & $\begin{array}{l}\text { Member- } \\
\text { ship }\end{array}$ & 91 & 53.6 & Win \\
\hline 2003 & Poland & POL2OO3 & EU Membership & $\begin{array}{l}\text { Member- } \\
\text { ship }\end{array}$ & 59 & $77 \cdot 5$ & Win \\
\hline 2003 & Romania & $\mathrm{ROM} 2003$ & EU Membership & $\begin{array}{l}\text { Member- } \\
\text { ship }\end{array}$ & 56 & 89.4 & Win \\
\hline 2003 & Slovakia & $\mathrm{SLK} 2 \mathrm{OO} 3$ & EU Membership & $\begin{array}{l}\text { Member- } \\
\text { ship }\end{array}$ & 52 & 92.5 & Win \\
\hline 2003 & Slovenia & $\mathrm{SLO} 2 \mathrm{OO} 3$ & EU Membership & $\begin{array}{l}\text { Member- } \\
\text { ship }\end{array}$ & 60 & 89.6 & Win \\
\hline 2003 & Sweden & SWE2OO3 & EMU Membership & Policy & 83 & 42 & Defeat \\
\hline 2005 & France & FRA2005 & $\begin{array}{l}\text { Constitutional } \\
\text { Treaty }\end{array}$ & Treaty & 69 & $45 \cdot 3$ & Defeat \\
\hline
\end{tabular}




\begin{tabular}{|c|c|c|c|c|c|c|c|}
\hline 2005 & Luxembourg & LUX2005 & $\begin{array}{l}\text { Constitutional } \\
\text { Treaty }\end{array}$ & Treaty & 89 & 56.5 & Win \\
\hline 2005 & Netherlands & NET2OO5 & $\begin{array}{l}\text { Constitutional } \\
\text { Treaty }\end{array}$ & Treaty & 63 & 38.2 & Defeat \\
\hline 2005 & Spain & SPA2005 & $\begin{array}{l}\text { Constitutional } \\
\text { Treaty }\end{array}$ & Treaty & 42 & 76.7 & Win \\
\hline 2005 & Switzerland & SWI2005a & $\begin{array}{l}\text { Schengen agree- } \\
\text { ment and Dublin II }\end{array}$ & Policy & 56 & 54.6 & Win \\
\hline 2005 & Switzerland & SWI2005b & $\begin{array}{l}\text { Free movement of } \\
\text { persons CEECs }\end{array}$ & Policy & 54.5 & 56 & Win \\
\hline 2006 & Switzerland & SWI2006 & $\begin{array}{l}\text { Cooperation with } \\
\text { CEECs }\end{array}$ & Policy & 45 & 53.4 & Win \\
\hline 2008 & Ireland & IRL2008 & Treaty of Lisbon & Treaty & 53 & 46.6 & Defeat \\
\hline 2009 & Ireland & IRL2009 & Treaty of Lisbon & Treaty & 59 & 67 & Win \\
\hline 2009 & Switzerland & SWI2009a & $\begin{array}{l}\text { Free movement of } \\
\text { persons } B G+R O\end{array}$ & Policy & 51.4 & 59.6 & Win \\
\hline 2009 & Switzerland & SWI20ogb & $\begin{array}{l}\text { Biometric pass- } \\
\text { ports Schengen }\end{array}$ & Policy & 38.8 & 50.1 & Win \\
\hline 2012 & Croatia & $\mathrm{CRO}_{2012}$ & EU Membership & $\begin{array}{l}\text { Member- } \\
\text { ship }\end{array}$ & 43.5 & 66.7 & Win \\
\hline 2012 & Ireland & IRL2O12 & $\begin{array}{l}\text { Treaty on SCG of } \\
\text { EMU }\end{array}$ & Policy & 40 & 60 & Win \\
\hline 2013 & San Marino & SMR2O13 & EU Candidature & $\begin{array}{l}\text { Member- } \\
\text { ship }\end{array}$ & 43.4 & 50.3 & Win \\
\hline 2014 & Switzerland & SWI2O14 & $\begin{array}{l}\text { 'Against mass } \\
\text { migration' }\end{array}$ & Policy & 56.6 & 49.7 & Defeat \\
\hline 2014 & Denmark & DEN2O14 & EU Patent Court & Policy & 55.9 & 62.5 & Win \\
\hline 2015 & Greece & GRC2O15 & $\begin{array}{l}\text { Draft Euro rescue } \\
\text { reform package }\end{array}$ & Policy & 62.5 & 38.7 & Win \\
\hline 2015 & Denmark & DEN2O15 & $\begin{array}{l}\text { Opt-in JHA, } \\
\text { Europol }\end{array}$ & Policy & 72 & 46.9 & Defeat \\
\hline 2016 & Great Britain & GBR2O16 & EU Membership & $\begin{array}{l}\text { Member- } \\
\text { ship }\end{array}$ & 72.1 & 48.1 & Defeat \\
\hline 2016 & Netherlands & NET2O16 & $\begin{array}{l}\text { EU-Ukraine } \\
\text { association treaty }\end{array}$ & Policy & 32.3 & 38.5 & Defeat \\
\hline 2016 & Hungary & HUN2O16 & $\begin{array}{l}\text { Resettlement } \\
\text { migrant quota }\end{array}$ & Policy & $40.4^{* *}$ & 98.3 & Defeat \\
\hline
\end{tabular}

*Officially invalid outcomes: Despite approved, the quorum in favour* or the turnout quorum** was not reached.

\subsection{Argument and outline of the book}

Answering the question of when governments win EU-related referendums requires several steps. The study flows from embedding the referendum in representative democracy, the 
procedural and institutional settings of the referendums in European countries, to the analysis of the actual EU-related referendums themselves. Moreover, in order to assess the impact of the outcome of the referendum, it is also crucial to find out how governments act if they lose referendums. The last part of the study is therefore dedicated to the impact of the governments' failed referendum outcome.

Chapter 2 starts by outlining the position of referendums in representative democracies. Although direct and representative democracy are mostly opposed to each other in theoretical debates, in fact the interaction between referendums and representative democracy has been acknowledged (Setälä and Schiller 2009: 4). Institutional actors do and have to consider both forms of democracy, particularly on questions related to statehood and independence. Those are questions the European integration process heavily touches upon. Especially in relation to the EU, referendums are considered as legitimizing instruments capable of restoring the citizen's control over and trust in EU-decision-making. This 'crisis discourse' of legitimacy problems has become the raison d'être of a 'renaissance' of referendum literature in recent decades (Hollander 2016). In addition to this normative point of view, an overview of institutional classifications of referendums is given in order to sketch what options governments have. From these options follows the discussion why referendums are called: because of structural legal requirements, or for reasons of appropriateness? Or, are they called by political elites to consolidate their interests, or by citizens to challenge those elites' interests (Hollander 2016: 14)? Finally, the chapter addresses the empirical literature explaining individual voting behaviour in referendums. It discusses the effects of issue voting, elite cues and second-order voting in order to find out to what extent these individual level factors matter for the outcome of the referendum at the aggregate level.

After this classification and embedding of referendums in representative democracy, Chapter 3 maps in which European countries EU-related referendums have taken place, on what issues, and who triggered them. This answers the question how domestic institutional structures constrain or enable government use of referendums. First, the legal framework of referendum legislation across European democracies in the context of EU matters between 1970 and 2016 is analysed, unfolding the potential for EU-related referendums across Europe. A 'referendum trigger model' shows who can initiate referendums, distinguishing between constitutionally mandatory and optional triggers.

Second, an inventory is made of which mandatory and optional referendums have been held and why. It could be that referendums are triggered by constitutional amendment, or that they are legally required due to a missing parliamentary majority. Alternatively the vote could have been triggered by governments to reinforce their power, to circumvent an opposing parliamentary majority, to underline the importance of the issue, and to resolve rifts within the government or within the governing parties (Closa 2007, Mendez et al. 2014).

Also, parliaments could trigger referendums for reasons of appropriateness or for mediating motives. Finally, citizens can trigger a referendum on EU issues to either set the agenda or to recall a decision already taken by political elites. (cf.Shu 2008: 423). 
After having described where referendums could take place and why, Chapter 4 addresses the issue under which conditions governments win EU-related referendums. Based on a comparative framework that includes the 61 referendums, an integrative theoretical explanation is explored for successful and failed referendum outcomes. These patterns are to be inferred by the method and technique of fuzzy-set Qualitative Comparative Analysis (OCA) (Ragin 2008, Schneider and Wagemann 2012). This method allows for the comparison of many cases and looks for combinations of conditions causing the outcome. It looks whether the referendum issue was e.g. supported by the opposition, and what the aggregate economic conditions were at the time of the referendum. The analyses yield explanations for these different outcomes, further drawing on the threefold typology of EU membership, treaty, and policy referendums. As these types of referendums mark a different context of the issue at stake, it is expected that the identified conditions work out differently if mediated by the type of referendum. The governments' success in EU-related referendums will be explained by the combination of political and socio-economic conditions, and by the type of referendums. The chapter also provides a brief analysis for defeated referendums, i.e. the unsuccessful, negated outcome.

Chapter 5 unravels deviant cases which were not explained by the solution patterns of Chapter 4. This chapter applies Comparative Process Tracing to find out why some cases are deviant and whether alternative causal mechanisms were at play compared to those found in the initial analysis. There are three deviant cases which concern the second Irish referendum on the Lisbon Treaty in 2009, the Danish referendum on the EU Patent Court in 2014, which both ended in government victory; and the Danish referendum on joining the Euro in 2000 which ended in government defeat.

Finally, Chapter 6 explores the consequences of the vote and addresses the question how governments cope with inconvenient referendum outcomes. It addresses 15 defeated cases in which the government lost the referendum and what strategies they deployed afterwards. Are governments willing to accept defeat? Is the lost case a partial defection of the ratification process of a treaty, does it mean total failure for the whole process, or does it imply a potential to opt-out by an EU member state? Although it seems that each overruled government had to invent its way out, a comparison of these 15 inconvenient referendum outcomes reveals that four main strategies have been followed. First, governments may accept the outcome by retaining the status quo, necessarily by negotiating an opt-out from further integration. A second strategy is to interpret the vote in new policies, shaped by (inter) national compromises in the spirit of the popular result. One could strike a similar deal by which a second referendum is consciously avoided. A third way is to circumvent the initial outcome by a second referendum. A fourth strategy is to neglect the outcome completely. The chapter also analyses the reasons behind the choice for each strategy to legitimise the referendum outcome.

The Conclusion summarises the key findings, attempts to generalise the results across the several chapters and suggests prospects for future research. What follows is a discussion of the contributions made in this study. The chapter also discusses the implications 
of the findings in the framework of the debate on referendums and the democratic decision-making process in the EU: It addresses questions about the use of referendums in the European integration process, what the current referendum means for the future development of the EU, and finally what future there is for EU-related referendums. Are there more referendums expected, or will some recent negative referendum experiences rather discourage governments to engage in direct democratic decision-making?

\subsection{Scope and limitations}

The study is positioned in the political science literature on referendums and European integration, but also includes some elements of comparative constitutional law on referendum provisions. It locates the EU-related referendum in historical perspective of referendums in Europe since the French revolution of 1789 and provides the main reasons when and why referendums were introduced in European states. Building on this historical perspective, the study developed a model to explain the current potential and practice of EU-related referendums in European democracies. The most prominent contribution lies in explaining at the aggregate level why governments win or lose EU-related referendums. The empirical fuzzy-set Qualitative Comparative Analyses using an original dataset provide a novel perspective in the referendum literature that allows for the discovery of new insights based on its focus on the interaction and combination of conditions. As the original dataset comprises the complete population of EU-related referendums from 1972 until 2016, it is argued that despite of the inductive nature of this study, the results will provide guidance to governments' success in future EU-related referendums in comparable circumstances. In this way, this study aims to contribute to the theoretical, empirical, methodological and societal debate on referendums. This study improves our understanding EU-related referendums are held, under which conditions governments win or lose them of why, and how governments cope with the outcome. In this way it uniquely contributes to the development of government strategies for future cases knowing which circumstances have to be considered when an EUrelated referendum is held. If it can be explained under which circumstances governments win or lose, this may influence the course and timing of future referendums during policymaking and ratification processes on European integration.

The scope of this study is limited in three respects. First, the (dis)advantages of the referendum instrument as such vis-à-vis representative democracy are not discussed, because this has already been done extensively by others (e.g. Butler and Ranney 1994). The focus of this study is not on whether the referendum is a good or bad form of democracy, but on the way it is used on EU-related matters. Hence, the existence of the referendum as direct decision-making mechanism is taken for granted. Second, as the study takes the nationwide referendum and its aggregate outcome as a unit of analysis, individual voting behaviour is not analysed as such. A third limitation is that the inclusion of all EU-related referendums does not leave room for in-depth case studies on all referendums, although some case studies are done in the Chapters 5 and 6 . Instead, by incorporating all cases the study provides a 
unique overview of the functioning of referendums in ruling the European Union.

\section{Notes}

1. Butler and Ranney argue for the use of referendums (not referenda), referring to the Oxford English Dictionary: 'Referendums is logically preferable as a plural form meaning ballots on one issue (as a Latin gerund referendum has no plural). The Latin plural gerundive referenda, meaning 'things to be referred,' necessarily connotes a plurality of issues' (Butler and Ranney 1994: 1)

2. A popular vote can be triggered by citizens or political actors, while a plebiscite can only be triggered by political actors.

3. The ratification of the Fiscal Compact in Ireland, the EC-EFTA Treaty in Switzerland or several bilateral agreements between Switzerland and the EU are considered Policy referendums.

4. The four outcomes in line the government but against the EU are the Swiss $(1997,2001)$ and Sammarinese (2013) popular initiatives on membership, and the Greek (2015) referendum on the draft bailout and austerity package proposed by the EU troika. All 15 cases lost by the government also reflect an anti-EU outcome.

5. The Appendix provides replication data for the fuzzy-set analyses of the empirical chapters as well as an encyclopaedic overview of all relevant data per referendum. 



\section{Representative Government, Referendums and the EU}

A referendum is a political instrument in which a proposed or taken decision on a public issue is put for approval to a mass vote. By referendums, citizens take direct control over law making and influencing the political decision-making process, by partially circumventing representative bodies (Butler and Ranney 1994, Eder 2010, Kobach 1993). Referendums can take different shapes and forms, depending on who controls the initiation of the referendum (political actors or citizens) and on what kind of issues is voted:e.g. constitutional amendments, the (recall of) legislation or even politicians, or citizens' popular initiatives or vetoes.

Understanding how and why EU-related referendums are held, under what circumstances governments win them and how governments deal with inconvenient outcomes, first requires insight in the position of referendums in representative democracies, in the existing classifications and triggers of referendums among European countries, and in the impact of campaign dynamics and voting behaviour on the outcome. This chapter reviews the literature on representation, referendums and the EU in order to find out why referendums exist and what is known about them. It discusses the referendum within the ideal form of democracy, its position towards representative democracy, and its different institutional classifications. Furthermore, the reasons why referendums are called are analysed, as well as the underlying explanations for individual voting behaviour in referendums.

\subsection{Referendums and democratic theory}

The strict classical notion of democracy means that the people governs directly. In such a democracy, laws, rules and regulations need legitimacy in order to be accepted by those who are obliged to follow them (Auer 2016: 402). Rousseau's 'direct democracy school' argues that "the only truly democratic way to make decisions on matters of public policy is by the full, direct, and unmediated participation of all citizens" (Butler and Ranney 1994: $12,14)$. The higher end that democracy seeks according to this notion is the full development of each citizen's full human potential. This can only be realised by the direct and full participation in public affairs, not by simply delegating civic powers to representatives. Direct democracy expresses the genuine will of the people and the primary source of political legitimacy (Batory 2018: 257). Rousseau considered direct democratic means of law making as legitimate, because equal and free citizens had -voluntarily- agreed upon those laws in their legal community: the 'Social Contract' between the citizens. Rousseau preferred direct democracy over representative democracy. Actually, he did not consider representative government to be democratic at all, because after elections, the citizens' will would be shaped by the representatives. Rousseau argued that the transfer of sovereignty from the people to their representatives should not take place. Sovereignty should stay among the people. The referendum would provide a perfect means to make laws which express this enlightened, objective 'genuine' 
general will (volonté générale) based on unmediated majority rule of citizens. This majority rule would bring about this indivisible general will - the common good of society - by balancing out the biases of the fragmented will of all individuals, and in this way enlighten the popular will (Setälä 1999: 36, 43). Despite the direct democratic ideal, in its purest form, direct democracy does not exist as stand-alone governing model and is currently not seriously considered as alternative for representative democracy (Gallagher and Uleri 1996: 243). Over the last two centuries representative democracy has been the norm (Qvortrup 2013: 12). Modern democracies are founded on representative systems, mainly because citizens do not have the capacities and time to decide on each issue directly. Nevertheless, sometimes referendums are held and have been introduced within the countries' institutional systems as Figure 2.1 shows.

In current conceptualizations of democratic theory, referendums and representative democracy are mostly regarded as incompatible. Referendums are sometimes posed as a 'threat' to democracy because they would frustrate representative decision-making processes (Mendez et al. 2014). Indeed, referendums allow voters to express positions that go against their party correcting the will of the representatives. But referendums are not a substitute for representative democracy (Qvortrup 2013: 8). The referendum phenomenon can rather be considered as an complementary set of decisional mechanisms that interacts with decisionmaking processes of representative government (Gallagher and Uleri 1996, Lijphart 1999). Particularly in the $20^{\text {th }}$ century, referendums have been introduced as additional means to representative democracy in order to increase individual public participation in the policymaking process and citizen's initiatives. The ideal of the unmediated participation of citizens encouraged the introduction of the referendum within representative systems, transferring the decisions usually made by politicians to the voters themselves (Bjørklund 1982: 240). So, the referendum limits the ability of the elected representatives to exercise their power. As such the referendum "may serve both as a sword in the hands of a majority that seeks to push through or legitimize a particular policy initiative and as a shield that makes it more difficult to pass legislation" (Setälä and Schiller 2009: 81).

Referendums proved to be an additional check and balance on the representatives' choices, particularly on issues organizing the institutional framework of the state when crucial questions on (a transfer of) sovereignty of the state appear in the light of international cooperation. This makes the referendum more than a simple reproduction of the balance of forces in parliament (Papadopoulos 2001). Institutional players have to and do consider both forms of direct and representative democracy, especially on questions related to statehood, inalienability of sovereignty and independence, or even endeavour to apply these to their strategic benefit (Hug 2009). The European integration process is the prime and most recent example of such international cooperation by which international and transposed domestic legislation has to be accommodated by suitable democratic decision-making on constituent foundations in order to legitimize the decisions taken (Lenowitz 2015). Hence, it is not surprising that referendums appear in the context of the European integration process. 


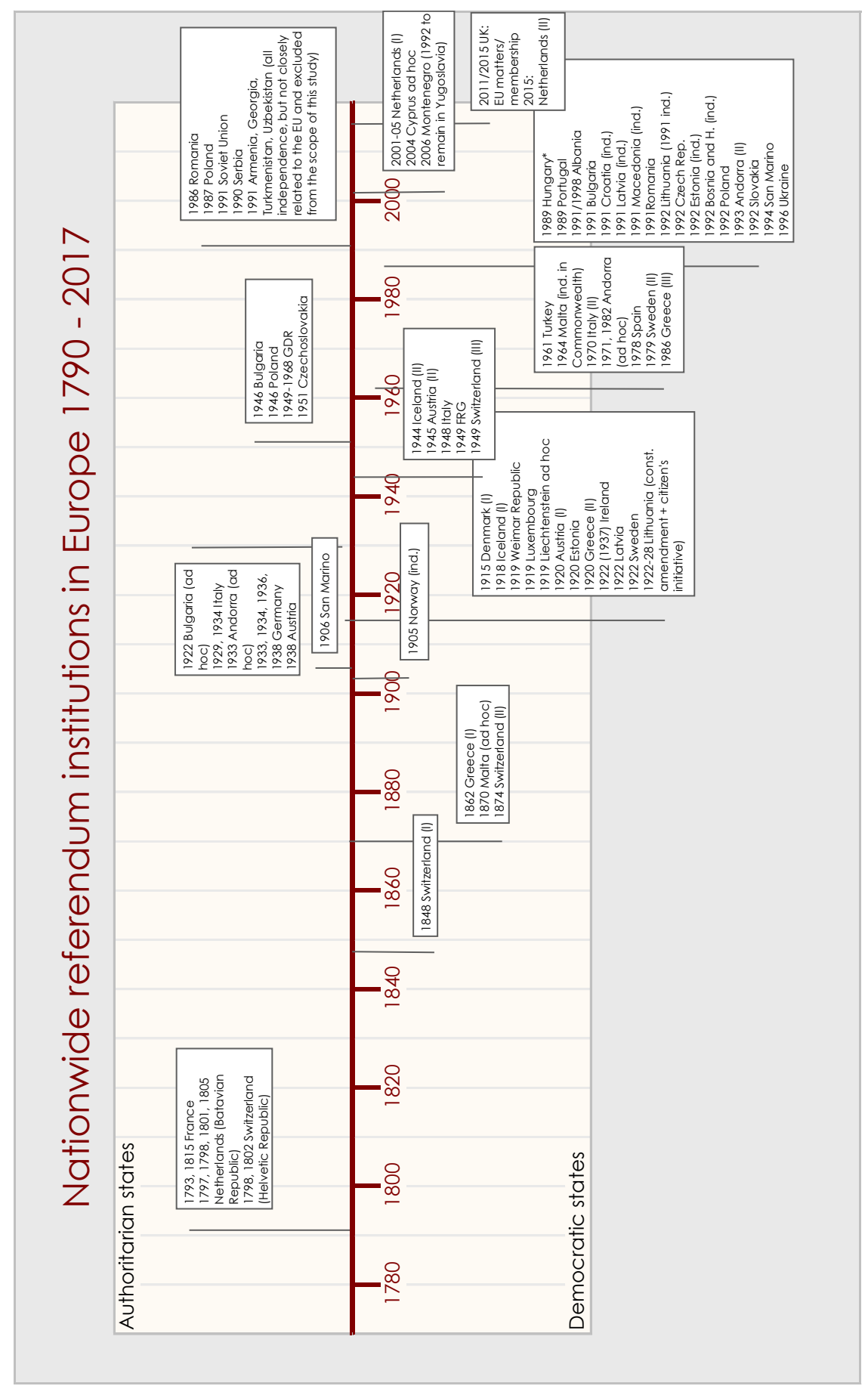

Figure 2.1. Nationwide referendum institutions in Europe 1790-2017. 


\subsection{The emergence of referendums in European democracies}

Why have referendums been introduced in European representative democracies? Besides the Swiss direct democratic practices in Alpine communities, the nation-wide referendum only appeared in European political systems after the French revolution of 1789. Figure 2.1 provides an overview of the introduction of referendums in Europe since the French revolution. In the timeline a distinction has been made between referendums in democratic countries and those under authoritarian rule. It indicates the year that the referendum was provided for by (ad hoc) law, or the moment that the country witnessed its first referendum experience, e.g. on the question whether it should become independent. Looking over the last two centuries, four main driving factors can be distinguished for the messy emergence of referendums: 1) the empowerment of (authoritarian) rule; 2) the quest for independence; 3) the demand for more direct citizen participation; and 4) the evolution of and increasing transfer of sovereignty to the European Union.

\subsubsection{Empowerment of (authoritarian) rule}

The first introduction of referendums was inspired by the developments of the French revolution. During the Napoleonic periods, referendums of imperfect democratic decisionmaking took place as they were characterized by authoritarian mobilization and fraud. It provided popular legitimacy to strengthen dictatorship. In the Napoleonic era the French authorities held some controlled plebiscites inspired by the treatises of Rousseau (see section 2.1). The second constitution, drafted during the brief Jacobin Republic (1792-1794) introduced both direct universal suffrage and the popular initiative on constitutional and legislative issues. The first French referendum was held on this constitution and this instituted the legitimacy of the constitutional referendum (Bogdanor 1994: 48). Shortly thereafter, two other French constitutions were approved by referendums. At the turn to the $19^{\text {th }}$ century, other authoritarian referendums were held in Switzerland and in the Batavian Republic to legitimise its new draft constitution. Some decades later, the French constitutional referendum of 1870 took place in a more balanced context when the previous authoritarian regimes of Emperor Napoleon III were liberalised. Nevertheless, the then Third and Fourth Republic remained hostile to the referendum instrument because the will of the people was identified with Parliament, and so it was abolished. Only after the Second World War, both the end of the Third Republic and the approval of new constitutions in 1945 and 1946 were legitimized by referendums with free and universal suffrage. The new constitution of the Gaullist Fifth Republic of 1958 contained permanent provisions for holding referendums, not only on constitutional amendments but also on ordinary legislation. The constitution itself was approved by referendum (Morel 1996: 67-73). In this Fifth Republic the referendum was supposed to legitimize strong leadership. President De Gaulle used the referendum as regular instrument, as a plebiscitary weapon to strengthen his legitimacy by the electorate. At least every three and a half years, De Gaulle appealed to the people either through a referendum or through a presidential election. Moreover, De Gaulle made clear that a rejection of his proposal 
by referendum would mean his resignation. During De Gaulle's rule, the referendum may be seen as the equivalent of the vote of confidence under a parliamentary system (Bogdanor 1994: 57).

After the unification process of Italy in the 1860s, the only two nationwide popular votes that took place were undemocratically promoted by the fascist regime in 1929 and 1934 in order to visualize the apparent popular consensus in favour of the authoritarian regime (Gallagher and Uleri 1996: 106). Also countries in Central and Eastern Europe employed referendums during the interbellum to legitimize their mainly authoritarian regimes. Due to the similar oppressive plebiscites of the Nazi regime during the 1930s, the new West-German Basic Law of 1949 purposely dropped the Weimar referendum instrument, however. Additionally, Greek and Spanish juntas held authoritarian plebiscites during their regimes. The legacies of dictatorship in Greece, Portugal and Spain which lasted until the 1970s also explain why referendums played a limited role, despite being provided for in their constitutions (see Chapter 3), when they transformed into democracies.

\subsubsection{Independence}

Many countries founded after the First World War included the referendum in their new constitutions. Norway declared itself independent from Sweden by referendum already in 1905. In the wake of the First World War, eight (sub-national) referendums were held to determine the borders in Europe, such as Nord Schleswig (Pelinka and Greiderer 1996: 22). The same occurred after the end of the Cold War when the collapse of communism gave rise to another wave of independence referendums. The first free referendums in Eastern Europe since the Second World War took place in Poland in 1987 and in Hungary in 1989, which constituted a defeat for the communist authorities. They were the "last-ditch attempts of putatively reformist but increasingly overwhelmed Communist elites to bulwark their failing defences by calling in the plebiscitary armies" (Brady and Kaplan 1994: 183). Another bulwarking attempt on the reform of the USSR was launched by Soviet leader Gorbachev in March 1991 as 'All-Union referendum', but it marked the beginning of its end. Despite Gorbachev winning, the vote opened the floodgates for more referendums. Lithuania, Estonia, Latvia, Georgia and Armenia proposed independence referendums instead in the wake of the collapse of communism in the USSR, and refused to set up referendum commissions for the All-Union referendum. Estonia, Latvia and Lithuania even held these independence referendums before the All-Union referendum took place, followed by Armenia, Azerbaijan, Georgia, Kirghizia, Turkmenistan, Uzbekistan and Ukraine later in 1991. The overwhelming support for the independence referendum in Ukraine in December 1991 determined the fate of the Soviet Union. Also in former Yugoslavia, referendums preceded independence proclamations in Slovenia, Croatia, Macedonia and Bosnia Hercegovina. The Bosnian Serbs voted for an independent Serbian state within Bosnia, while Montenegro voted to remain with Serbia. Montenegro would hold another, successful, independence 
referendum in 2006. All these votes marked the stages of the splintering of Yugoslavia, followed by a war which was only to be concluded by the Dayton Peace Agreements. The referendums were used by 'provincial' elites and leaders of minorities to serve the divisive interest of nationalism, and contributed to the dissolution of Yugoslavia (Brady and Kaplan 1994: 175-209). Hand in hand with the emergence of these new democratic states, provisions for referendums were increasingly being added to their new constitutions after the end of the Cold War. Without exception, the new constitutions of Central and Eastern European countries have introduced referendums (Hug and Tsebelis 2002: 465, Ovortrup 2005: 1).

\subsubsection{Direct citizen participation}

Several times during the last two hundred years, the demand for more direct citizen participation fostered the introduction of referendums in countries' political systems. In the $19^{\text {th }}$ century initially only in a few states such as Switzerland, in which 57 of 68 nationwide referendums took place up to 1900. With the foundation of the Swiss Confederation, the 1848 Swiss Constitution provided for the obligatory referendum for any constitutional amendment or popular initiative for a total revision. Other decision-making procedures relied on representative democratic mechanisms. This changed with the introduction of the optional legislative referendum in 1874, and the initiative for partial constitutional revision by referendumin1891.Theoptional referendum ontheratificationoftreaties was introducedin1921. . During the $2 \mathrm{O}^{\text {th }}$ century the referendum was used in many more countries, most frequently in Switzerland, Denmark, France, Ireland and Italy.

The emergence of new European states after the First World War fostered the introduction of the referendum, such as the Weimar Republic (1919), Austria (1920), Ireland and Sweden (1922) (Bogdanor 1994: 92). Many of the new democratic constitutions, such as the one of the Austrian republic, were inspired by the Weimar constitution of 1919 and reflected the general political mood in Europe after 1918 favouring national self-determination with the citizens as constituting the highest sovereign of the state. Ireland provided for the referendum after its independence, although its current referendum provisions were only introduced by the new constitution of 1937. These provisions were approved by the first Irish plebiscite, while at the same time this referendum abolished the provision for the initiative. So in the end the provisions as introduced in 1922 were never applied (Gallagher and Uleri 1996: 86-88).

Denmark introduced the mandatory referendum for constitutional amendments in its constitutions of 1915 and 1920 and the optional referendum in 1953. In Sweden the consultative referendum was inserted in the constitution of 1922, inspired by comparable demands for more democracy after the First World War. The first Swedish referendum was in 1922 on the issue of the prohibition of alcoholic beverages. Another clause on binding referendums on constitutional amendments was introduced by the constitution of 1974 (Ruin 1996: 171-5). In Italy the post-war constitution of 1946 provided for the abrogative referendum 
as popular appeal against parliament in exceptional circumstances (Bogdanor 1994: 612). Despite these referendum provisions, however, it took until 1970 before the relevant implementing legislation was passed. The political class was unaware that the abrogative referendum would prove to be used that frequently (Bogdanor 1994: 88-9). More than 60 referendums have been held since then in Italy. However, the turnout requirement meant that more than half of it was declared void (Marxer and Pállinger 2009: 44-45).

The 1968 revolts in the Western world sought more participatory individualism, independent from a political party's cue or from the virtue of social class or religion. The referendum functioned as alternative participatory mechanism, when citizens became dissatisfied about the perceived malfunctioning of the political system and the way they were represented (Qvortrup 2018a: 22). Hence, the (worldwide) use of referendums has increased since the 1960s. Mechanisms for direct democracy "have become increasingly central in worldwide efforts to legitimize political change within democratic systems" (Ruth et al. 2017: 1-2). Their increased importance is also the result of the popular demand for politicians to become more responsive and accountable to the interests of citizens.

This development was paralleled in countries where the referendum is used as part of the regular machinery of government. In polities such as Switzerland and Italy, in which voters can launch popular initiatives or vetoes, those bodies and policies are strongly affected by (the threat of) referendums (Butler and Ranney 1994: 258). In Switzerland, this threat of a popular initiative is often sufficient to cause compromises and broad consensus among the elected representatives (Kobach 1994: 151). Compromises may have the effect of convincing a larger number of voters. Sometimes a counterproposal is offered against a popular initiative. The incidental or structural character of the referendum instrument has an impact on the policies and institutions of states.

Even in some countries where it was not part of this regular machinery, the referendum has been introduced on an ad hoc basis. In the UK and Scandinavian democracies, referendums are only held when elected bodies call them. For instance in Finland, in 1987 an act was passed how such ad hoc referendums should be regulated. Earlier referendums had been held on ad hoc legislation in the 1930s and 1990s based on parliamentary guidelines (Suksi 1996: 52-55). Also in Norway, the Netherlands and the United Kingdom, ad hoc referendum laws were passed. The Norwegian separation from Sweden, and approval of the monarchy in 1905 were legitimised by such ad hoc referendums. Notably, the first nationwide referendums in the Netherlands and in the UK took place on EU-related issues.

\subsubsection{Transfer of sovereignty to the EU}

The emergence of supranational organisations such as the European Union contributed to the rise of referendums related to a transfer of sovereignty. With the increasing contestation and supranationalisation of European integration particularly since the 1990s, referendums on EU matters became more frequently legally required and desired instruments to legitimize 
this integration process, not instead, but in addition to representative support, to supplement representative government. For instance, the Danish constitution of 1953 introduced a mandatory referendum on delegation of Danish sovereignty to international authorities if a bill on this issue does not obtain a 5/6 majority in the Folketing (Svensson 1996). This rule proved a hurdle to be taken when Danish EC accession was at stake in the 1970s. The policy process of transferring sovereign powers of member states to the EU demands a continuous consideration by institutional players, whose decisions should be legitimized by representative or direct democratic mechanisms; or a combination of these. This demonstrates that currently politicians coping with these issues are in a permanent balancing act between representative democracy and referendums, within their country's constitutional system.

\subsection{The institutional context}

Not all referendums look the same. The literature on referendums includes several classifications in what ways political institutions allow or oblige citizens a direct say on policy issues (Gallagher and Uleri 1996, Hug 2002, Hug and Tsebelis 2002, Mendez et al. 2014, Morel 2007, Tridimas 2007). The institutional context of each referendum forms structural constraints with which the political actors have to cope when they (have to) use the referendum. Who or what decides to hold an EU-related referendum or not? When is the initiation of the vote within or beyond control of the government? In order to answer this question one can classify the opportunities and constraints of the referendum instruments and the actors who (want to) use it.

Before classifying the kinds of referendums, it first makes sense to distinguish between the referendum and the citizen's initiative to put an issue on the political agenda. The main difference between the referendum and the citizens' initiative is that the former implies a public vote on the issue at stake, while the latter only obliges the political representatives to deliberate on the issue without necessarily having a public vote on it. The citizens' initiative also differs from the popular initiative, in the sense that the popular initiative classifies as a referendum including a public vote on the issue, while the citizens' initiative does not include such a vote.

Within the classification of referendums, the first distinction to be made is between mandatory and optional referendums. This distinction can be framed in a model, defining different categories who may trigger the process of the referendum, inspired by the veto player theory model of Hug and Tsebelis (cf. 2002: 477). Figure 2.2 shows that EU-related referendums are possible in two ways: either it is mandatory, or it is optional. If mandatory, the referendum is required by law. If optional, it can be triggered by the government, the parliament or the citizens. A referendum is not possible if referendums have been excluded in principle as such, or if the issue concerned is excluded from referendums either by law or by (precedent) judgements of (constitutional) courts. 


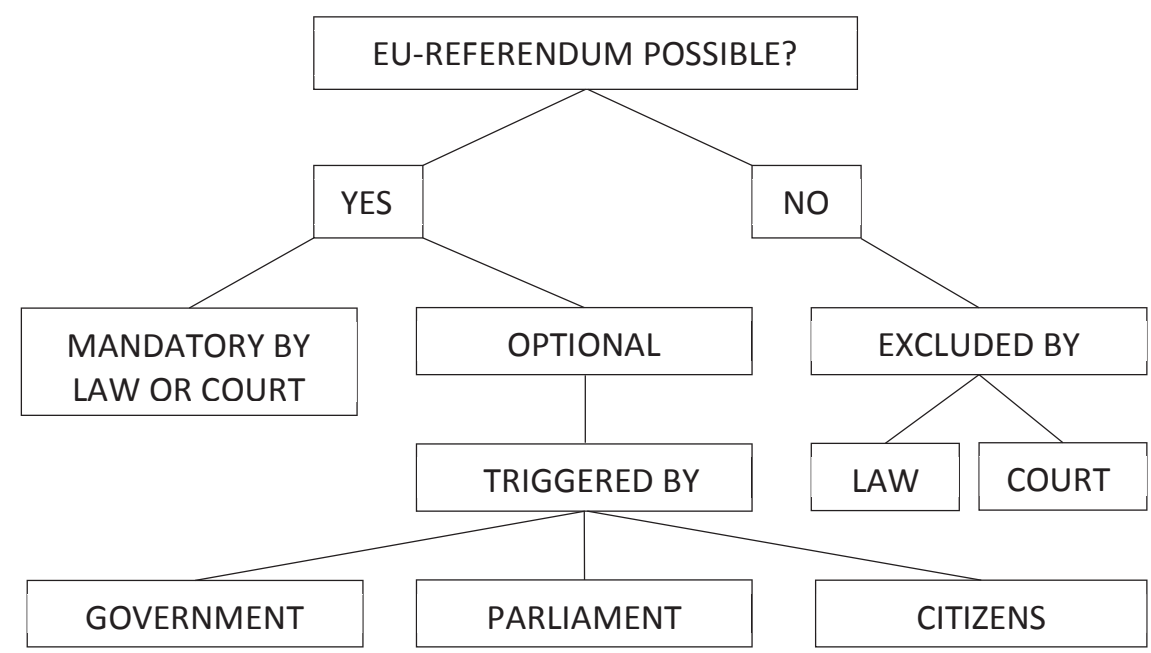

Figure 2.2. Actors and reasons to trigger EU-related referendums.

\subsubsection{Mandatory referendums}

When a referendum is mandatory, the decision to hold a referendum is generally taken out of the hands of the politicians. Mandatory referendums imply that governments or other actors do not decide about (not) having a referendum. It is required by law to hold one. Some constitutions require referendums on changes of the constitutions themselves. Other constitutions include provisions to hold mandatory referendums on other specific issues. In some countries for instance, constitutional amendments enabling the accession to an international organization, including a transfer of competences, require approval by a referendum. In addition, constitutions sometimes provide for referendums when international treaties are to be concluded which include such a transfer of competences (Albi 2005). Regarding EU-related issues, a mandatory referendum deals with either a transfer of powers, joining an international organisation or an amendment of the constitution. In this way, the referendum is an enabler to transfer sovereignty to a supranational organisation.

Sometimes it is up to political forces to decide whether a referendum is mandatory. In Denmark, for example, the Ministry of Justice decides whether an envisaged treaty implies a transfer of sovereign powers. If then the treaty is not passed by the required five-sixth parliamentary majority, a so-called 'legislative referendum' is constitutionally required. In Austria, political elites considered that its EU accession constituted a total revision of the constitution paving the way for a mandatory referendum (Mendez et al. 2014: 74). A referendum can also become legally mandatory due to a judicial ruling. ${ }^{5}$ For instance, a judicial ruling on the Irish parliamentary ratification of the Single European Act in 1987 triggered the referendum on the act. So three distinct scenarios have been identified when a referendum is mandatory: first, when the constitution so requires. Second, when the legislature fails to 
reach the required (super) majority for ratifying a treaty, thus triggering a constitutionally mandatory referendum. Third, where a Court decides that a referendum is constitutionally required.

\subsubsection{Optional referendums}

Optional referendums are not prescribed by law or by courts, but are triggered by the government, the parliament, or the citizens. In contrast to the mandatory referendum, the optional referendum implies that there is an actor (promoter) who begins the procedure for obtaining a popular vote on a determined 'object' or 'decision'. Gallagher and Uleri came to a fourfold typology of optional (un)controlled referendums and initiatives:

1. decision-promoting referendum (called by the government),

2. decision-controlling referendum (called by the parliament),

3. decision-promoting initiative (popular initiative), and

4. decision-controlling initiative (popular veto) (Gallagher and Uleri 1996: 6-11).

Who controls the initiative indicates the intended effect of the vote: decision-promoting or decision-controlling (Morel 2007: 1044). Referendums called by governments are considered a 'controlled' referendum when it is solely sponsored on the initiative of the government. If so provided by law, the government could call a referendum by decree, or draft a bill which is to be adopted by parliament. Government-controlled referendums are intended to produce results that favour the government's authority, while uncontrolled ones are launched to bring about changes that the government resists. In case it is triggered by parliament and outside the government's control, it is considered an 'uncontrolled' referendum. If not already provided by law by which MPs could call a referendum, also parliament has the possibility to change or draft new (ad hoc) laws. If triggered by citizens, the referendum can take the form of a popular initiative or popular veto (not to be confused with the citizens' initiative as discussed at the beginning of section 2.3). A popular initiative means that a certain number of citizens put a new, own issue to the vote. This is a decision-promoting initiative. A popular veto means that a certain number of citizens may ask a referendum on an issue on which government and parliament have already decided. By such a decision-controlling initiative a decision just taken is put to a rejecting vote, or an implemented decision is put to an abrogative vote.

Within the classification of optional referendums, one can also distinguish between the moments a referendum can be triggered, depending on the legal provisions of the decision-making trajectory. It can be triggered before the executive or legislative takes the official decision (ex ante); when the decision is taken by the executive or legislative but not yet implemented (within a limited period); when the decision is taken and in force (ex post, abrogative, popular veto); or independent of representative decision-making, by means of a popular initiative. 


\subsubsection{Legal impact of the result: consultative or binding}

Two outcome-oriented distinctions can be made how the referendum result should be dealt with. Referendum outcomes can be consultative or binding, and the result can be either valid or invalid. This determines the value formally assigned to the outcome of the vote (Gallagher and Uleri 1996: 7). Consultative referendums can be called by the government or the parliament, or by the citizens in the form of popular initiatives. Consultative means that the political actors are not bound by its outcome. If the outcome is binding though, the political actors have to accept, respect and implement the outcome. "However, most de jure advisory votes have been considered de facto as binding ones, whereas binding votes sometimes still allow scope for parliamentary manoeuvring" (Gallagher and Uleri 1996: 7). While it is politically difficult to ignore an advisory referendum, a binding outcome which lacks legitimacy (e.g. due to a very low turnout) may be challenged by a new referendum in the following years. When they cannot be enforced for a durable period, the 'binding referendums' are quite fragile (Morel 2018b: 32).

A second distinction impacting on the legal effect of the referendum is the validity of the result. This validity is determined by two potential parameters: the turnout quorum and the approval quorum. The turnout quorum means that a minimum part of the electorate has to participate in the referendum by casting a valid vote. This minimum part often constitutes a percentage of the current electorate or is related to the participation in the most recent election. The approval quorum contains a minimum number of valid votes which either approve (or reject) the issue at stake. It may take the form of a minimum percentage of the electorate voting in favour, or constituting a super majority of the voters who actually voted. If this approval quorum is not met, the referendum outcome is invalid. As a consequence, the political actors are not bound by the result of referendums whose turnout or approval quorum is not met.

These classifications of the status of the result are relevant for this study in two ways. First, the consultative or binding nature of the referendum determines the freedom of manoeuvre for political actors how to deal with the result, particularly if the outcome is inconvenient for the government (as is discussed in Chapter 6). Second, the validity thresholds may either serve as an opportunity or as a constraint for these political actors. If for instance the government wants to maintain the status quo in case of a not so salient popular initiative, it could not just campaign against the initiative, but also try to keep the campaign at such a low profiled level, that the required turnout or approval quorum is not met. Otherwise, if the government itself aims for a change of the status quo and requires a valid referendum outcome, these quorums may pose serious hurdles to achieve this.

\subsection{The political context}

Why would political actors or citizens call optional referendums? It can be argued that due to their unpredictable outcomes, referendums are difficult devices for governments. Therefore, 
governments might be expected to stay away from such a device particularly because referendums bear the risk of a vote against the government's preferences (Closa 2007). At the very least referendums seem to be a high-risk strategy for the ratification of EU initiatives. As LeDuc notes: "More often than not, the outcome is a defeat for political elites who became convinced that it would not be a difficult matter to persuade voters to support proposals that seemed perfectly reasonable to them and that appeared to enjoy broad support across many diverse groups" (LeDuc 2009: 139). At critical junctures in the 1990s, governments in e.g. Norway, Denmark and Sweden were left with parliamentary majorities pursuing closer European integration, but proceeding with a context of the electorates expressing a preference against this. As a consequence of these referendum outcomes, Sweden is not in the EMU, Denmark opted out of EMU and reserved its right to limit participation in Justice and Home Affairs, Defence and EU Citizenship. Norway has rejected membership twice but nevertheless participates in the internal market and takes part in e.g. Schengen more closely than Denmark. According to Setälä and Schiller, "many No votes in government-initiated referendums also indicate the limits of governmental control, and the government's capacity to manipulate referendum campaigns" (Setälä and Schiller 2009: 78, 216).

The unpredictability and undesirability for the government of some outcomes raises the question why governments do hold referendums. The argument that EU issues are too exotic to fit easily within traditional structures of representative party politics, does not sufficiently answer the question why so many member states opted for referendums. What are elite's motives behind calling referendums and when are elites in an advantageous position to hold them, despite these unpredictable and unwanted outcomes? Three overriding reasons for holding EU-related referendums have been distinguished: constitutionality, partisan calculus, and appropriateness (Mendez et al. 2014), based on previous studies by Morel (2001) ${ }^{6}$ and Bjфrklund7 (1982: 247-49). Constitutionality means that there is a legal requirement to hold the referendum. Partisan calculus and appropriateness imply that political actors voluntarily opt for the referendum, in order to maximize party or government power or to meet legitimacy concerns. As the reason of constitutionality overlaps with the category of mandatory referendums, only the reasons of partisan calculus and appropriateness will be discussed here.

\subsubsection{Partisan calculus: politically motivated to call}

Why do political actors trigger referendums just for political gains? Governing parties would be reluctant to call a referendum as they have little to gain from an outcome that supports and much to lose from one that counters their position (Dür and Mateo 2011). ${ }^{8}$ Sometimes maximising party or government power is the overriding motivating factor. On the one hand at the European level, Hug and König argued that European integration is a two-level game by which governments may, by announcing a referendum, use a constrained domestic ratification procedure as a tool to increase their bargaining power at the European level and to gain concessions (Hug and König 2002). Hurdles raised by domestic ratification procedures 
may affect the bargaining outcome (Hobolt 2006: 160). Ratification by referendum seems to be a credible obstacle which governments can employ. The reliance on a tied-hands strategy due to the necessities of a ratification by referendum, might have an advantage in interstate negotiations as long as the domestic voters are more demanding than the government itself and as long as the other, European, side is willing to give in (Schneider 2018:422). The timing of launching a referendum matters in this respect: when the referendum is optional and called before the end of the negotiations, it is considered an additional ratification hurdle. If called after the conclusion of negotiations, it is less expected to affect the bargaining outcome. This constraint appears even more surprising when it is not relying on a specific constitutional foundation, for instance when the constitution allows for referendums on unspecified 'issues of national importance' (Hug and Schulz 2005: 6). This implies that after exhausting their bargaining value, the commitment to a referendum forces government to call (and win) it. On the other hand, at the national level the referendum can be considered as an instrument as an alternative rational calculation to deal with domestic partisan and electoral struggles (Closa 2013: 80). At this national level, there are several partisan motives for governments to pledge for referendums.

First, governments or political parties may use them as a tactical weapon to strengthen their power and undermine their political opponents. They are very keen about the result of those referendums that they have initiated (Morel 2007: 1050). This powerreinforcing argument is mainly framed in government terms, but Oppermann locates referendum demands also as a strong political weapon in the armoury of many Eurosceptic parties. They may not only seek to stop or change the policy objectives of the mainstream parties, but also be drawn into the public limelight and bestow on them a disproportional standing compared to their marginal role in the parliamentary arena (Oppermann 2012: 219). Parties that expect electoral gains support a referendum, and those that expect electoral losses oppose a referendum.

Second, referendums are a mechanism to secure the policy objectives in the absence of a parliamentary (super)majority by circumventing parliamentary opposing 'veto players'. This is a clearly policy seeking objective in which the government is aware of the lack of large elite support which makes parliamentary ratification uncertain. Governments take the risk of a treaty referendum in order to avoid a defeat in the vote in parliament, preventing the opposition of succeeding at any rate (Finke and König 2009: 358-9). Hence, governments and parliamentary majorities look for compensatory, extra-parliamentary, gains when calling referendums. It is rather unlikely that they would call referendums that carry a high risk of undermining representative democracy, if there is a suitable parliamentary majority (Setälä and Schiller 2009: 214).

Third, referendums may serve to mediate or depoliticise internal divisions of or between political parties along anti- and pro-European lines. Particularly when elections were approaching, governments seek to depoliticise the issue from the campaigns, especially when they could set the referendum (or election) date. The closer the next election, the more intense party competition and the more likely second-order voting would take place at the referendum (Finke and König 2009: 351). In that case pro-European mainstream parties would 
be willing to meet the referendum demands of Eurosceptic parties and call a referendum "in order to evade battles over European integration in the arenas of inter- and intra-party politics" (Morel 2007: 1047). Eurosceptic demands and pressures were a driving force behind government decisions to promise and hold EU referendums that were not constitutionally required, in order to neutralise the interparty political effects of those demands. It is a defensive strategy to avoid the political costs of increasing party political contestation on European integration. This makes referendums also a tool of depoliticisation. By announcing a referendum, the government hoped to remove it from the political or electoral agenda, reducing its vulnerability to Eurosceptic parties. Mediation or depoliticisation devices therefore do not have as primary aim the victory of the government's standpoint, although it ought to be a very important aim as well (Morel 2007: 1054). Depoliticisation is not about eliminating the 'political' from decision-making processes per se - it could rather sudden politicize the salience of an issue (cf. Atikcan 2013: 126) - but rather about distancing the governing majority from these processes. "Referendums can be a way of legitimizing a political decision that might otherwise be a source of continuing conflict" (LeDuc 2009: 140). An issue which causes inter-party divisions, "may not be possible to resolve through parliamentary politics and is therefore likely to drive the leader of the governing party to call a referendum" (Tridimas 2010: 132). It relieves governments of the responsibility of deciding on the contentious issue themselves and of defending their decision in the arenas of interparty electoral competition and intra-party politics, by expanding the European issue into the arena of mass politics. Intra-party rifts are defused 9 because a referendum allows different opinions within one party to coexist (Oppermann 2012: 217-20). However, instead of relief or depoliticisation, EU referendums may also provide Eurosceptics a forum to make their case. EU referendum demands tend to be highly popular among Eurosceptic parties. In this way the referendum carries the risk of mobilising Euroscepticism, which may be particularly harmful if it escalates intraparty divisions. This in turn makes governments more reluctant to commit to EU referendums (Oppermann 2018: 245).

\subsubsection{Appropriateness: politically compelled to call}

The reason of appropriateness is operating when legitimacy concerns are the dominating factor. It is influenced by cognitive frames and norms of what is right, by which the European political arena nurtured discourses for EU-related referendums, given similar developments in other member states. First, the reason of appropriateness has explanatory power if rather normative arguments in favour or against direct democracy instruments on matters of constitutional or national importance apply, and no tactical or electoral advantage may be derived from calling the referendum. ${ }^{10}$ It is characterised by domestic political pressure exercised on governing elites, which makes the referendum unavoidable and de facto obligatory. After careful calculation, the consequences of not calling a referendum would be unacceptable for the government: it may be "exposed to strong criticism and suffer negative political fallout" (Morel 2007: 1056). 
A second reason of appropriateness is the 'precedent': if an issue was decided by referendum in the past, the same occurs when the same issue reappears. Politically it may be too costly for the incumbent to deny holding a referendum for instance when it risks losing the next election (Tridimas 2010: 131). In such cases, governments (or parliaments) do not hold the referendum due to constitutional imperative or partisan calculations, but due to considerable political pressure from citizens, or due to lock-in effects of earlier referendums on a similar issue.

A third reason of appropriateness applies when a precedent is set in other countries, also referred to as the domino referendum. Oppermann suggests that referendum commitments in one country may bring about transnational normative spillover in other countries, reinforcing the pressure on governing majorities to grant EU referendums and stimulate a self-reinforcing dynamic of plebiscitary politics in European integration. The logic of appropriateness may affect the standards of what counts as an appropriate process of European policy decision-making at home. Denying a referendum on an issue may, benchmarked against other countries, be considered inappropriate (Oppermann 2012: 217, 222). ${ }^{11}$ Whereas de facto politically obligatory referendums are motivated by precedent factors, in domino referendums the extraterritorial factors are decisive. As Closa points out, this logic is also influenced by imitation processes of constitutional borrowing, reflecting domino effects of pledging referendums from one country to another. The interconnection of national ratification processes - on the same issue and time- means that the choice for referendums may affect other member states. This creates a kind of path dependency or 'institutional determination', not just in countries in which referendums are rare, but also in countries which repeatedly held EU treaty referendums such as Denmark and Ireland (Closa 2007: 131525, Closa 2013: 74-77). The 1970s membership referendums in Denmark and Norway provided a precedent for the referendums in the 1990s in Norway, Sweden and Finland, while these 1990's referendums provided a model for the CEECs' accession referendums in 2004.

\subsubsection{Offensive or defensive pledges?}

The government's position to pledge (or to be confronted with) EU-related referendums can be regarded in in an offensive or defensive mode. Oppermann (2013b) argues that governments pledge offensive referendums in order to realize potential political gains, to improve on the status quo and proactively pursue their agenda. Governments commit to referendums to reinforce their public prestige aiming for acclamatory consent and to weaken the opposition. It may enlarge the electoral appeal of a party or politician (Morel 2007: 1047). Hence, governments hold offensive EU referendums to bolster their domestic support when the EU is popular and the next national elections are far away (Prosser 2016). Second, at the European level governments may initiate referendums to endorse the European integration process or to stop it. Alternatively, governments pledge defensive referendums in order to avoid potential political losses facing elections or policy objectives at the European level, particularly when the $\mathrm{EU}$ is unpopular and elections are close. They employ referendum commitments to prevent a 
worsening of the status quo. This depoliticisation pledge insulates the EU matters from interparty and intra-party competition. It could circumvent an opposing parliamentary majority or intra-party rifts. 'This rationale should be particularly powerful if the European issue in question meets with low public support and if elections are imminent' (Oppermann 2013b: 688-9). A depoliticisation strategy does not always make a victory certain as miscalculations can and do occur. Moreover, if governments use the referendum tool to avoid a controversial decision, the 'referendum may not produce a victory but it will provide a government with an excuse for failure' (Tierney 2012: 125). Then the government is not seeking success, but its own survival.

\subsubsection{Conclusion}

To sum up, apart from the constitutionally required or triggered referendums, the literature has identified partisan reasons for pledging EU-related referendums. Partisan calculus can be the driving motive for pledging referendums in four instances. First, governments use referendums as a tactical weapon to strengthen their power vis-à-vis political opponents. Second, referendums are an alternative mechanism for securing ratification and circumventing opposing parliamentary majorities. If citizens or MPs trigger a referendum, from their perspective this may also have a policy seeking (or blocking) motive. If the number of required signatures or MPs is relatively low in combination with a contested policy proposal, a referendum could relatively easily be triggered. Third, referendums may resolve cross-cutting intraparty, or intra-government rifts (e.g. along anti and pro-European lines). In this way the referendum serves as mediating device by which internal divisions can be masked. Fourth, it serves as depoliticising device when the contested issue can be isolated from the political debate and upcoming elections.

The logic of appropriateness applies when political actors deem the referendum necessary or unavoidable because of external political pressure (domino effect), domestic precedents or simply consider the issue of such national importance that not having a referendum would be inappropriate. Obviously, governments may have multiple, both offensive and defensive, motives for pledging referendums. These reasons of triggering referendums are a relevant factor to investigate, because it sheds light on the position the government has taken before the vote.

\subsection{Voting behaviour in EU-related referendums}

In the context of the question when governments win EU-related referendums it is also necessary to understand how voters behave in referendums. Although analysing voting behaviour suggests a view from the voter's perspective, the purpose of this section is to look what individual-level factors could mean on the aggregate level. Three interpretations appear in the literature based on which voters make their choice. First, citizens vote according to their 
preferences and evaluation of the information at their disposal. Second, if voters do not have attitudes and information on the issue, voters use heuristics: elite cues and rationalisation of the issue not based on previous attitudes. Third, citizens can express their (dis)satisfaction with the national government (Font and Rodríguez 2009: 169-70, 180).

\subsubsection{Issue voting and EU attitudes}

Do voters really know what they vote upon? One of the most common criticisms of direct democracy is related to the lack of voter competence on the issue at stake (Hobolt 2007b). Voter competence concerns the ability of individuals to accomplish their specific task - in this case make a rational choice in a referendum. Such rational choice may simply imply one that is based on (whatever) reasons. It holds that the average citizen is unable to decide how beneficial the agreement in question is, leading to a reliance on party cues and government evaluation (Batory 2018: 257). Hobolt defines a competent choice of the voter as:
"[A] competent choice is related to the accomplishment of a specific task and should thus be based on preferences pertaining to that task...A competent vote in referendums can thus be defined as one that is based on preferences specific to the issue on the ballot and that would be the same if full information were available" (Hobolt 2007b: 156).

Although doubts about the wisdom of the public opinion have been voiced over time, research on voter competence shows that the public is well able to make a rational choice, albeit on different levels of information and referencing parameters. Trechsel and Kriesi argue that the voter's knowledge of the issues at stake is the most powerful variable in explaining turnout. When people are exposed to more information during a campaign, they are less likely to abstain. The more profound the knowledge, the greater the probability of voting. High-intensity campaigns both activate issue preferences and result in more issue voting. Moreover the voter's perception of the impact of the issue matters, in general or on his daily life. Campaigns play a vital role in this information process:

"The campaign constitutes the decisive period concerning the question when and how voters inform themselves, make up their minds and finally decide how to vote. A majority of deliberation takes place in the run-up to voting day, stimulating active exchange of information between political elites and the voters, as well as among the voters themselves" (Trechsel and Kriesi 1996: 196 ff.).

Voters are open to influence by campaigners who offer more information or better explanations of the ways in which government activities affect them. They learn about the referendum through the campaign and media coverage and adjust their preferences accordingly, enabling them to form 'enlightened' preferences'. A more vigorous campaign produces a vote merely based on substantive issues (Garry et al. 2005: 215). 
Related to issue voting is the value attributed to positive general heuristic attitudes towards the EU. This means that in case the government favours a referendum proposal implying more European integration, the larger the positive attitude in a country is, and the larger the number of Yes votes will be (Wagschal 2007: 61). Hobolt and Brouard, however, challenged this conventional view of a single scale from anti- to pro-European attitudes, because these attitudes also become intertwined with traditional domestic concerns. The general attitude of the EU may be positive, but voters may distance themselves from certain aspects (Hobolt and Brouard 2011: 319). Likewise, Marsh found in his comparison of Irish EU referendums that the difference in EU support did not differ significantly between the won and lost referendums, even when the issue was salient and turnout was high (Marsh 2015: 175). Knowledge about the EU does not guarantee a positive vote, but implies that voters are more likely to rely on their own convictions and are less likely to follow the recommendations of national elites (Hobolt 2009: 107). In fact, the relative importance of EU attitudes is mediated by the intensity of the campaign. The impact of individual attitudes is stronger among those exposed to campaigns, and the greatest in referendums with the most intense campaigns. Hence, political awareness mediates the relative impact of EU attitudes on voting behaviour (Hobolt 2005: 90-1). "Higher levels of campaign exposure have a positive effect on the likelihood of voting Yes in an EU referendum regardless of a person's attitudes towards the EU. For people who are neither strongly pro- nor anti-European, the amount of campaign information received can make the difference between a Yes and a No vote" (Hobolt 2007a: 106).

\subsubsection{Elite cues}

If voters do not have previous attitudes, do not rely on information at their disposal, or do not have sufficient information on the issue, the question remains whether their decisions in referendums reflect elite cues..$^{12}$ Indeed, a campaign is never just about 'informing' voters. Fundamentally, it is about winning. Governments have a strong interest in the victory of their position at almost every referendum (Morel 2007: 1054). As Steenbergen et al. note, party elites can no longer safely assume that their supporters will follow their lead in referendums. Instead, it provides strong incentives for parties to align their policy stances with the positions of their constituents (Steenbergen et al. 2007: 19). While there may (not) be some neutral sources of information available to voters over the course of a campaign, much of the information they will receive comes (in)directly from campaign actors who have a stake in the outcome (cf. LeDuc 2009: 142). The use of elite cues is particularly important among more informed voters, as a certain level of information is needed to be aware of elite cues. "Voters take their cues from these and other campaign sources, as well as from individuals, groups and organizations which they identify" (LeDuc 2002: 145). It seems that elite cues are stronger if there is a larger degree of elite consensus among politicians on the issue.

Voters do not only rely on information from elites, they also rely on their party preferences. Partisan cues become more important when the advertising campaign is weak. 
However, if voters have a very limited knowledge of party politics, these party endorsements may be potentially misleading, since the EU dimension does not constitute an integrated part of the main political dimensions (Hobolt 2007b: 168, 176). European integration issues are often difficult issues to explain to voters. Hence by following a familiar party cue, the voter may be distracted if the party's stance on the issue is unfamiliar to him. "International treaties are often technical texts, which implies that summarizing and framing the issue is a key component of the campaign" (De Vreese 2007: 4). Schuck's study of referendum campaign dynamics even finds that certain positive news framing by the incumbent could mobilize the opposing side instead. The more positive news favouring the issue, the more opposing voters were ready to vote against: the revered mobilization effect (Schuck 2009).

The novelty and saliency of the topic are important parameters during the campaign to determine whether the vote is merely based on issue voting or elite cues. Campaigns can make a difference if voters have limited information at their disposal on the issue (Popkin 1991: 70). "The impact of the campaign environment is likely to be even greater in referendums where people are asked to decide on often unfamiliar topics where elite cues (partisanship) are less informative" (Hobolt 2007a: 85). In this respect, LeDuc classifies three types of referendum campaigns: opinion formation, uphill struggle, and opinion reversal. First, opinion formation refers to the campaign where voters cannot generally be expected to have well-formed opinions on an issue that has not previously been subject of any broad public debate in e.g. elections.

"Some referendums fitting such a profile are those that involve multiple issues, complex international treaties, or large packages of constitutional provisions. Constitutional referendums often display this pattern, with elite driven projects being decisively rejected once the voters had learned enough about them" (LeDuc 2007: 30).

A new, undiscussed issue, or an issue in which parties take unpredicted stances, is likely to produce greater campaign volatility. Voters will need more time to form opinions and are often influenced directly by the discourse of the campaign. In the absence of strong predispositions, information becomes more critical. Hence, opinion formation campaigns are more receptive for elite cues to be followed. Elites take strong positions at the beginning of the campaign, while during the campaign, opinions begin to form (LeDuc 2009: 143, 2007: 29-35). Second, an uphill struggle campaign implies that opinion is much firmer and less subject to rapid change because voters have strong elite cues based on partisanship or ideology and are receptive to arguments from familiar and trusted political leaders. Cleavage or ideological issues in which parties take well-known positions, hold the least potential for opinion change over the course of a short campaign. Much attention is paid to undecided voters (LeDuc 2002: 158-60). Third, opinion reversal takes place when the campaign on a reasonably well-known issue takes on a new direction during the campaign. Often this occurs when opposition groups are successful in 'changing the subject' or raising doubts about the issue. Opinion reversal campaigns show that certain predispositions of voters and pre-existing elite cues are less likely to be followed, and issue voting becomes more dominant. 
The existing literature, however, does not clarify how much campaign information matters for winning the referendum: if both the Yes and No sides are waging serious campaigns, the information they generate is likely to have a cancelling-out effect on each other's side. The strongest campaign effects are expected when there exists asymmetry of information between the two campaigns, either because of biased reporting or because one campaign was run better than the other (Holbrook 1996: 16-18).

\subsubsection{Evaluating the government}

Scholars disagree on the impact of informative campaigns on the outcome. It may also be that voters determine their vote on the performance of the incumbent government. These second-order considerations contrast with the argument that voters choose on the issue itself. "Voters compare their policy preferences with the policies of the incumbent party and then render a decision based on how satisfied they were with the performance of the party" (Holbrook 1996: 8). The second-order thesis has been formulated by Franklin: "Referenda conducted in the context of national party politics, with the government of the day urging ratification of a treaty they have themselves negotiated, will inevitably be contaminated by popular feelings about the government" (Franklin et al. 1995: 102). As Morel argues, the fact that 'the policy submitted is originated at the government or supported by it induces voters to deal with the government rather than with the issue'. It embodies an implicit question of confidence in which governments could be hit by the 'punishment trap' irrespective of the issue at stake, particularly if a government has been long in office and rests on only a small parliamentary majority (Morel 2007: 1055).

The influence of policy factors such as immigration and the state of the economy enhance this second-order voting behaviour. Ensuring a Yes vote in a referendum, "any government calling a referendum must be very popular to compensate for the negative impact of economic pessimism and anti-immigration sentiments in order to see its proposal endorsed by Europe's citizens" (De Vreese and Boomgaarden 2007: 199-200).13 "Evaluations of the economy have also been found to play an important role in referendum voting, although indirectly by driving support for the government" (De Vreese and Semetko 2004: 165). This is underlined by the finding that "government endorsements have a stronger effect on the opinions of people who support the government than on those who do not" (Hobolt 2009: 117). However, in countries where European integration has remained low-salient and parties have avoided competition, party endorsements may not provide reliable cues for voters and voters' competence levels will be lower.

Connected to second-order voting is the timing of the referendum vis-à-vis the electoral cycle. Although Szczerbiak and Taggart contest the association of the referendum outcome with the number of years the government has been in office, Qvortrup claims that new governments are more likely to win a referendum on an EU matter because it often enjoys a 'honeymoon period' (Qvortrup 2016, Szczerbiak and Taggart 2004). Alternatively "governments that have been in office for a long time tend to lose EU referendums" (Qvortrup 
2016: 65). Timing vis-à-vis elections matters. The time since the last elections provides a significant explanation to the referendum outcome. The longer the period, the more likely a failed outcome is (Wagschal 2007: 65). As LeDuc states:

"The chances of an unpopular prime minister late in a government's term winning such a referendum are undoubtedly smaller than if the campaign is led by more credible or popular figures in a more positive setting... Second-order effects can easily doom a referendum vote in a volatile setting, even if opinion on the underlying issue is favourable" (LeDuc 2007: 41-2).

When the EU is unpopular and elections are close, governments hold defensive referendums just before the election to avoid being punished by voters for pursuing an unpopular EU policy. Alternatively, governments hold offensive EU referendums to bolster their domestic support when the EU is popular and the next national elections are far away (Prosser 2016). In this way, governments are purposely triggering second-order effects in referendums.

\subsubsection{Conclusion}

Based on the discussion of the existing literature on individual voting behaviour, it can be concluded that aspects of issue voting, elite cues and second-order voting could be relevant at the aggregate level. For this study the position of elite cues and the support for the incumbent are considered more relevant than the EU attitudes of individual voters, because this study looks for explanations for the referendum outcome at the aggregate level as well. Individual EU attitudes are mediated by the intensity of the campaign: if the campaign is intense this mediates the impact of the underlying EU attitudes on the aggregate outcome of the vote.

\subsection{Conclusion}

This chapter reviewed the existing literature on representation, referendums and the EU in order to find out where referendums come from and what their place is in the political systems of European states. Why can and do EU-related referendums take place, why do governments win these referendums and how do governments cope with the outcome? Regarding the first question, this chapter has shown that the introduction of the referendum can be seen in as a reaction to revolutionary periods and the aspire for more direct citizen participation. Referendums have been introduced in European countries over the last two centuries for mainly four reasons. First, regimes used referendums to empower their authoritarian rule. Second, referendums were used to express the quest for independence of a new country, as was most recently illustrated in Scotland (2014) and Catalonia (2017). Third, referendums were introduced in response to demands for more direct citizen participation. This occurred shortly after the end of the First World War and after the 1968 movements for more democratisation. 
Finally, the European integration process itself proved an incentive for referendums, in order to legitimise the evolving transfer of sovereignty from the national to the European level and to respond to citizens' demands to decrease the perceived democratic deficit of the EU.

Second, the discussed classifications made clear who or what can trigger EUrelated referendums, and what the status of the result means for the outcome of the vote. These classifications form the basis of Chapter 3 in order to find out in which countries EUrelated referendum can be held and are actually triggered. Some referendums are triggered automatically (because required), some by political actors in power (optional top-down), and some call for prior collection of citizen signatures (optional bottom-up) (cf. Ruth et al. 2017: 1). This enables to map the structural constraints in which referendums (have to) take place across Europe. These structural constraints are important in this study, because they determine the institutional framework in which EU-related referendums have been held and to what degree these referendums form hurdle for the negotiation and ratification of international agreements, as will be assessed in the following chapters. From these classifications one can conclude that referendums can potentially be triggered at several moments in the decision-making process by four different 'actors'. In the strategic context of the EU decision-making process, it is of prime importance to know who (or what) may trigger the referendum. The constitution or comparable acts could trigger a mandatory referendum, while the government, the parliament, or citizens could trigger an optional referendum. In Chapter 3 is analysed what the current mandatory and potential triggers of EU-related referendums are in democratic European states. This will show in which countries EU-related referendums are possible, in which countries these were actually held and whether the government did win or not.

Third, apart from mandatory referendums, two overriding arguments for pledging referendums are distinguished: partisan calculus (empowerment, policy seeking, mediation or depoliticisation), and appropriateness (domestic pressure, precedents or domino effect). These arguments will be taken up in Chapter 4 as a tool to find out whether governments found themselves in an offensive or rather defensive referendum mode. Is it for the government a favourable or rather difficult institutional context to hold, win, or rather prevent the referendum?

Fourth, on the basis of individual voter analyses it has been argued that some elements of issue voting, elite cues and second-order voting provide useful insights on the circumstances under which governments may win such a referendum. First concerning issue voting, voters who have more information can better connect their judgments and their vote, so that substantive considerations become more crucial in their vote. Second, elite cues may be relevant at the aggregate level if there is a lack of elite consensus. In case of elite polarisation, the elite cues will play a more dominant role and enhance the saliency of the campaign. Party recommendations appeared to be less important for those who had more information and for those who are less influenced by party stances, while at the same time party cues can matter only if citizens have enough information about these parties. Third, the second-order effects could play a role in two ways. The popularity of the government 
among individual voters on election day may be reflected in the support for the government on the referendum issue in parliament: do at least the incumbent parties endorse the issue? Moreover, the government which is enjoying its honeymoon seems to enjoy larger popular support for its policies compared to a government that has long been in office. Hence, the shorter the referendum takes place after the elections, the more chances the government has to win it.

Apart from the general literature on referendums reviewed so far, the next chapters reconstruct empirically which potential for EU-related referendums exists across European democracies, which referendums were held and why, and under what conditions governments could win them. As hardly any literature exists on the question how to deal with the referendum outcome, this topic is to be extensively explored in Chapter 6 of this study.

\section{Notes}

1. The Social Contract, trans. Charles Frankel (New York: Hafner, 1947), Bk. III, chap. 15, p. 85, quoted by Butler and Ranney (1978: 31):

2. Sovereignty cannot be represented for the same reason that it cannot be alienated; its essence is the general will, and that will must speak for itself, or it does not exist; it is either itself or not itself; there is no intermediate possibility. The deputies of the people, therefore, are not and cannot be their representatives; they can only be their commissioners, and as such are not qualified to conclude anything definitely. No act of theirs can be a law, unless it has been ratified by the people in person; and without that ratification nothing is a law.

3. "The English people believes itself to be free; it is gravely mistaken; it is free only during the election of Members of Parliament; as soon as the Members are elected, the people is enslaved; it is nothing." (Rousseau 1762: Bk. III, Ch. 15: 141)

4. The referendums in Nazi Germany took place in 1933 to leave the League of Nations, in 1934 to approve Hitler as Reichskanzler, in 1936 to approve the Reichstag selected by the Nazis, and in 1938 on the Anschluss of Austria (Ovortrup 2018a: 20).

5. From 1918 until 1986 seventeen nationwide referendums took place in Eastern Europe. The seven controlled 'referendums' under Communist rule between 1946 and 1986 had ostensibly high approval margins.

6. This provision was still in force at the time the first Swiss EU-related referendum would take place in 1972 on the ratification of the EC-EFTA Agreement. In 1977 the rules on treaty referendums were spelled out clearly. "Any agreement involving a collective security organization or a supranational community is treated as a constitutional amendment and must win a double majority in an obligatory referendum. All other treaty arrangements are subject to a referendum if one is demanded by 50,000 voters. Only a popular majority is required" (Kobach 1994: 105).

7. A parliamentary initiative can sometimes even enforce a referendum if supported by a minority. 
8. Morel (2001) has presented four reasons why governments decide to initiate referendums. First, governments may want to consolidate their power by calling a referendum that they feel relatively certain will pass. Second, referendums may be used to resolve internal divisions within the governing party or coalition of parties. Third, referendums may be used to pass treaties that would not otherwise be ratified. Finally, referendums may be 'de facto' obligatory even when they are not constitutionally required.

9. Bjфrklund (1982) distinguished three main reasons for calling referendums, which would all classify under Mendez' logic of partisan calculus: minority weapon (i.e. policy seeking by opposition), mediation, and lightning rod (i.e. depoliticisation).

10. "A government party may find it beneficial to call a referendum if it is reasonably certain of being victorious (...) Nevertheless, sometimes electoral competition can push government parties toward embracing a referendum, even if they are uncertain about victory (...) In the presence of substantial opposition to a European treaty, avoiding a referendum would hurt the electoral prospects of government parties since they would be open to attack on this issue by the opposition in an election campaign. Under this condition, losing a referendum may be less bad for the government's electoral prospects than steering clear of one" (Dür and Mateo 2011: 473).

11. In 2004 the French Socialist Party held an internal referendum on the Constitutional Treaty in order to decide which position to adopt vis-à-vis the forthcoming referendum. The result of 58 percent in favour and 42 percent against did not prevent defenders of the 'No' side from actively campaigning. Some analyses even suggest that this intra-party rift was a principal cause of the French 'No' (Closa 2013: 55).

12. Particularly the announced referendums on the Constitutional Treaty seem to have stimulated a discourse towards constitutional procedures for ratification, linking the Treaty to referendums. Governments in Spain, France, Portugal, Poland, Luxembourg and a Dutch parliamentary majority appealed to the argument that the Treaty represented a qualitative change in the European integration process which required direct legitimation by its citizens.

13. Spillover effects should be strongest ' when debates in different countries take place around the same time and deal with similar issues, as often happens in the cases of accession or treaty referendums'. In contrast the spillovers should be much weaker when referendums are constitutionally required and routinely part of the country's European policy making process (Oppermann 2012: 223).

14. One should be cautious of taking elite cues as a one-way street in which voters follow the elite. It might also be the case that vote-seeking, opposing parts of the elite position themselves on different sides of the debate and, in that way, follow the divided public opinion.

15. Most of the time, these popular sentiments are based on formal documents and statements, which are filtered and interpreted by the media, making the press as least as important. 


\section{When are EU-related referendums held?}

This chapter aims to find out why and how EU-related referendums actually take place. Answering this question requires discussing the preconditions constraining the role of governments, what options these governments had in determining the underlying content of EU-related referendums, whether this changed over time, and which choices they made within their national institutional contexts. To answer the main question why and where EU-related referendums (could) have taken place, one first needs to address for each country the question whether it is possible or even required to hold a referendum and under what conditions. A subsequent question is which referendums are enabled even when no legal framework is providing for them. A first taxonomy presents the legal possibilities for triggering EU-related referendums across European democratic countries. A second taxonomy outlines where and on what issues EU-related referendums actually took place and why these were triggered. Third, it is analysed why some envisaged or desired referendums did not occur eventually.

\subsection{The legal contexts of referendums}

In order to understand the role of political actors in referendums, it first has to be figured out what institutional structures constrain this role. The country-specific conditions can change the structure of the decision-making process over time and influence the choice of the ratification instrument (cf. Finke and König 2009: 344). The country-specific legal context has to be connected to the country's relative concepts of law at a given time, embedded in a certain cultural, historical, political-societal and geographical space. These qualities of the legal system shape the genuine legal character of the state, for instance whether it is democratic or authoritarian. All states may have formal and substantive referendum laws, but comparing these on a legal equal footing is only of relative significance. Each law has to be regarded in the normative spirit of the time and space in which it was created (cf. Elzinga 1988), which may differ completely between neighbouring country in the same era. In the dynamic, non-deterministic spirit of its time and space, referendums can be triggered on the level of formal law and (or) substantive law. On the level of formal law, referendum rules are enacted by an institution, e.g. the government, the parliament or jointly. It may prescribe different procedural forms: in what circumstances referendums are mandatory or optional, and in what circumstances the result is consultative or binding. It could be that a referendum is only triggered if a formal transfer of sovereignty is at stake or if the subject falls within the parliament's competences. On the level of substantive law, referendum rules may not just have been provided formally by an act or constitution, but also on substance the (normative desirability for a) referendum provision can be considered as an act, acting as a new source of constitutional law. For instance, referendums on the independence of a new state were not provided by act (the state did not exist yet and the old existing state was 
not legitimising these referendums) but were nevertheless considered as having legitimate force. An EU-related example at the level of substantive law is the ad hoc decision by the regional parliament of Greenland to organise a referendum whether or not to leave the EC, despite the lack of a legal referendum provision. Both the regional Greenlandic and national Danish political actors considered the referendum outcome as a legitimate source to prepare for Greenland's exit from the EC by 1985 (see section 3.3.2).

As has been discussed in Chapter 2, referendums in European countries can have a mandatory or optional character. Mandatory referendums deal with a with change of the constitution or concern a so-called 'transfer of powers' clause. The most pronounced subjects of mandatory referendums related to the EU are constitutional amendments, treaty ratification or a transfer of powers to international organisations. The referendum is mandatory by the constitution or required by law, e.g. when the necessary parliamentary majority is not reached. Optional referendums are driven by political motives. Referendums are generally pledged in order to fulfil other political objectives: strengthening rather than challenging representative decision-making (Hollander 2016). Here the argument of partisan calculus (empowerment, policy seeking, mediation and depoliticisation) or appropriateness (peer pressure, precedent or domino effect) could apply. Also citizens can trigger referendums for policy seeking reasons (to propose, stop or change an envisaged policy). These arguments are not mutually exclusive, however.

In the next section a comparison is drawn between mandatory, optional, and excluded referendums per country. The legal provisions per country are provided in the Appendix (IDEA 2016, Direct Democracy Navigator 2016). Table 3.1 shows which countries provide for mandatory and optional EU-related referendums and Table 3.2 shows when these were held. For each country is indicated per column under what conditions EU referendums are mandatory, or when they are optional. In the latter instance, it indicates which actor (government, parliament or citizens) can trigger the vote (or not), on what issues and under what conditions.

Referendums took place in 28 of the 43 countries that this study investigated. Although the relationship of third countries with the EU can be considered less intensive compared to the relationship of member states, all countries have certain ties with the EU (by means of trade agreements or stabilisation and association agreements). Therefore, there is no reason to exclude these non-member states from the analysis. Counties which are ruled by non-democratic regimes such as Belarus and Moldova have been excluded, however.

\subsection{Mandatory referendum regimes}

Twenty-three of Europe's 43 democratic countries provide for mandatory referendums on matters which (might) relate to the European integration process. In the next sections a categorisation is made first concerning mandatory referendums on constitutional amendments, followed by mandatory referendums on a transfer of powers and joining 
international organisations.

Constitutional amendments. Within the 19 countries providing for mandatory referendums on constitutional amendments, one can distinguish between any constitutional amendment, a revision of fundamental articles (including a transfer of powers) and a total revision. In Germany, the Basic Law only provides for a national referendum on a new constitution or Ländergliederung (restructuring the German regional borders). Austria has a comparable system which demands a referendum on a total constitutional revision. The constitutions of sixteen other countries may only be amended by referendum, albeit under different conditions. In contrast, Bulgaria, Hungary, The Netherlands and Portugal explicitly exclude referendums on constitutional amendments.

Treaty ratification, transfer of powers and joining international organisations. Eleven countries must hold a referendum when a transfer of sovereign powers to international authorities is pursued (see the second column of Table 3.2). This is the case in Denmark (if a five-sixth parliamentary majority is not met), in Latvia (in questions on EU membership), in Lithuania and in Switzerland. Furthermore, it has become legal practice in Ireland as its constitution has been adapted to EU treaty modifications since 1986. In Hungary, the overriding importance of EU accession was 'rewarded' with a binding referendum, specifically provided for in the Constitution for this purpose in December 2002 and swiftly repealed afterwards.

The constitutions of some countries of former Yugoslavia (Macedonia, Croatia) and former Czechoslovakia (Slovakia) contain phrases on the association or dissociation from a union or community with other states, which could be used as legal base for their referendums on (future) EU accession. For Slovakia, however, this provision was intended to be applied with regard to the relations within former Czechoslovakia and could hence not serve as a legal basis for calling a popular vote on its EU accession. Therefore, the Slovak Constitution was amended in 2001 by adding a paragraph specifying that the Slovak Republic could transfer the exercise of a part of its powers to the European Union. Such an accession treaty was valid with just the approval of the National Council. In France, since 2008 in principle referendums should be held on treaties pertaining to the accession of any new state to the EU. It was not applied yet to Croatian accession, but is expected to be held on any new enlargement. Since the 2011 European Union Act has come into force and as long as it is an EU member, the United Kingdom must hold referendums on issues involving any EU treaty and a lot of other detailed cases, such as introduction of Euro or Schengen border controls. This Act was the result of a fifteen-year-power struggle for an EU referendum in Britain on the course of the integration process. It was a kind of referendum lock to which only the government had the key (Closa 2013: 78). Justifying this referendum lock, the government argued that it was aimed at decentralising power to the British people on the big decisions on the direction of the EU (Gifford and Wellings 2018: 269). Despite the government's -discretionary- referendum commitment, due to the UK's tradition of parliamentary sovereignty, it is not clear whether the outcome of this kind of mandatory referendums will be binding. 
There are no legal provisions on other EU-related issues of national importance which could trigger a mandatory referendum. Hence, Table 3.1/3.2 does not contain a column of mandatory referendums on these issues of national importance. 


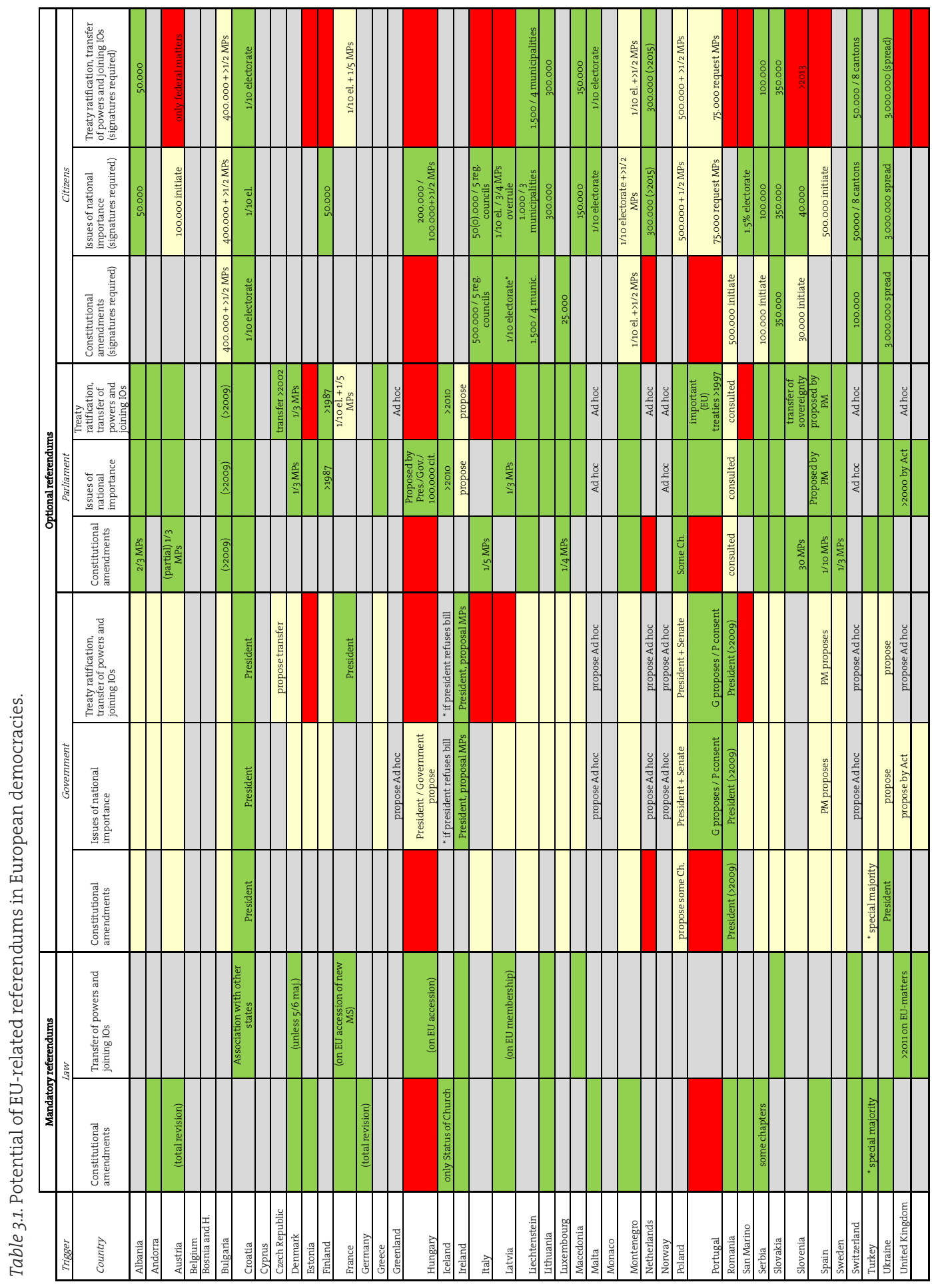




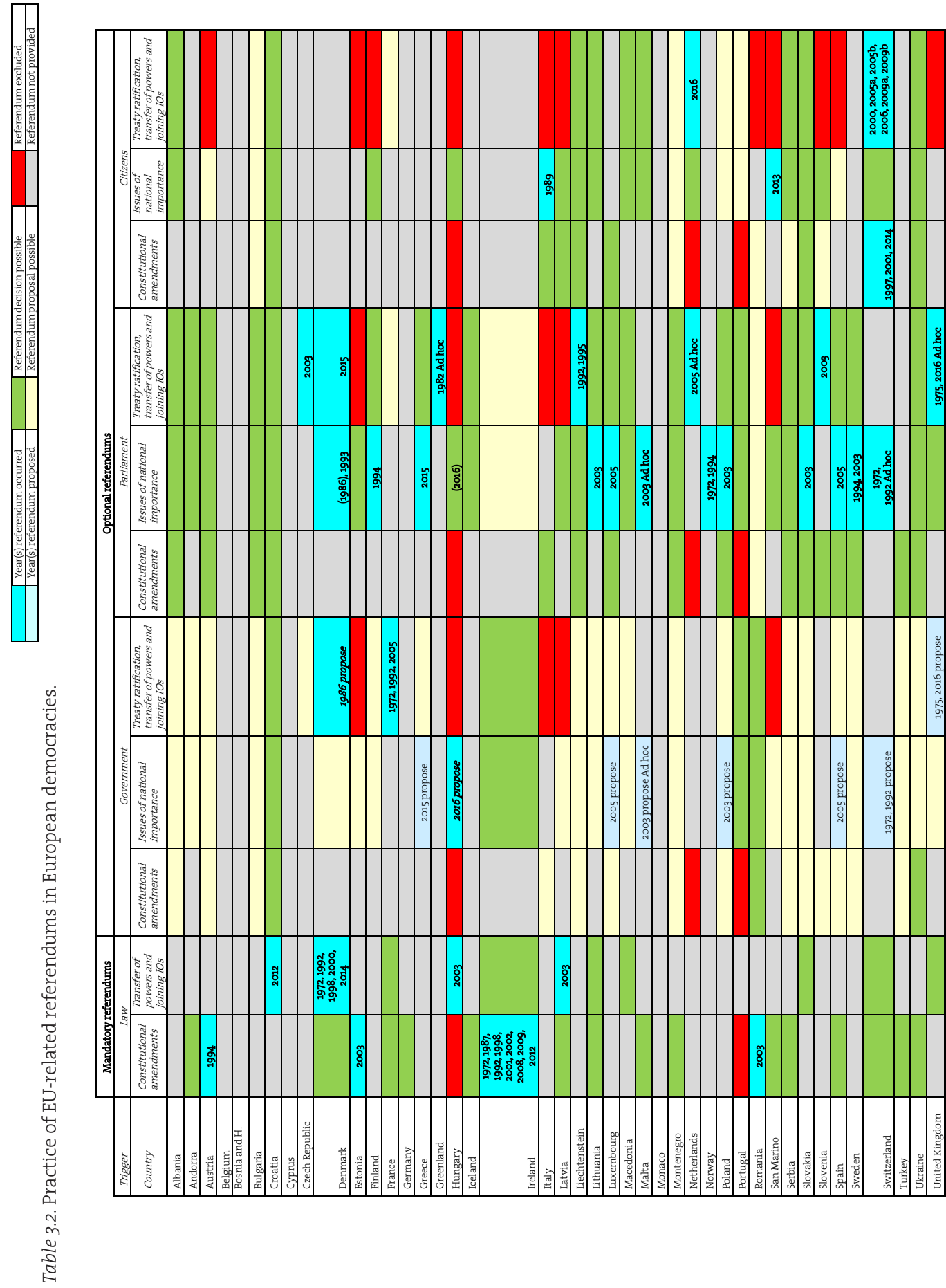




\subsection{Optional referendum regimes}

In 36 of the 43 countries studied it is possible to hold referendums on EU-related matters. These referendums can be triggered by governments, parliaments and citizens; or they are mandatory as discussed in the previous section.

\subsubsection{Options governments have}

In three countries executives have the opportunity to call a referendum on constitutional amendments. In Croatia, Romania and Ukraine the President may trigger these, whereas in Montenegro, the government may formally propose this to parliament. In Turkey the president may submit the amendment to a referendum only if, after reconsideration, the Grand National Assembly readopts the amendment without any changes. Hungary, the Netherlands and Portugal explicitly exclude optional referendums on constitutional amendments.

Referendums on issues of national importance can be triggered by the presidents of Croatia, Portugal, and Romania irrespective of parliamentary consent. In Ireland, though, parliament can request the president to decline to sign a bill 'of such national importance' that the will of the people ought to be ascertained first. Hence, the president can only trigger a vote after parliament has urged to do so. In 30 other states ${ }^{14}$ the government may (or has to) propose referendums to the parliament, but is always dependent upon its assent. Though, in Spain such a plebiscite has to be proposed by the prime minister and successively has to be approved by parliament in order to trigger it.

If not explicitly excluded by law, these issues of national importance also cover the category of 'treaty ratification, transfer of powers to and joining international organisations'. In Croatia, Ireland, Portugal and Romania, the president can trigger such a referendum. In France, the President may (on recommendation of the government or a motion of the two houses of parliament), put government bills relating to international treaties to a referendum if they would affect the functioning of public institutions. In Latvia, the provision allows the president to suspend a bill for two months, during which it can be referred to the people if sufficient signatures are gathered (Closa 2013: 71).

\subsubsection{Options parliaments have}

Compared to the options that governments have, parliaments have more opportunities to call for referendums on constitutional amendments. This is the case in 16 countries. In six of these, a minority of MPs is sufficient to trigger the vote, ${ }^{15}$ whereas in Albania only a twothirds majority suffices. In Poland, parliament may only invoke a referendum related to some constitutional chapters. Issues of national importance are the most common possibility for 
parliaments to trigger EU-related referendums. This is regulated as such in 26 countries (see Table 3.1). In Ireland the parliament may only propose such a referendum to the president and in Romania the president has to consult the parliament before he takes a decision. In Spain in contrast, the parliament is dependent on the prime minister's proposal to call a referendum. In Denmark and Latvia, a minority of one-third of the MPs suffices to call the referendum. In the United Kingdom, parliament must pass a specific act in each instance, based on its 2000 framework act for referendums. In Belgium, Bosnia and Hercegovina, Cyprus, Monaco and Portugal (until 1989) there is no constitutional or legal basis for a referendum, which could be regarded as ruling out a referendum. A binding referendum has been deemed unconstitutional by the Belgian Council of State in several cases (Raad van State 2004). In Cyprus the only referendum so far -in 2004 on the Annan Plan to resolve the Cyprus disputewas just triggered by parliament without a legal base (Mendez et al. 2014: 123).

The options parliaments have for referendums on treaty ratification, a transfer of powers and joining international organisations are largely covered by the options they have on referendums on issues of national importance. This applies to 23 countries. Ad hoc laws to enable these votes have been made in Malta, the Netherlands, Norway and Switzerland. Slovenia though permits parliament only to call a referendum on (special) treaties concerning a transfer of sovereignty. Votes on (ordinary) treaty ratifications are excluded. Where there is no such provision, referendums have not been permanently introduced or are quite exceptional (Council of Europe 2013: 232). In contrast, Estonia, Hungary, Italy, Latvia, and San Marino explicitly exclude treaty ratification from referendums. Apart from this, the Czech constitution insists that the ratification of a treaty, by which certain national powers are transferred to an international organisation or institution, requires the consent of parliament, unless a Constitutional Act regulates that such ratification requires the approval obtained in a referendum. This provision was especially designed for a referendum on Czech accession to the EU. The act stated that parliament's normal powers of decision and treaty ratification on accession were to be replaced by a referendum. Accordingly it has not been possible to organise national referendums on other subjects. ${ }^{16}$

\subsubsection{Options citizens have}

Comparing the possibilities for popular initiatives shows that in eight countries citizens can initiate referendums on constitutional amendments. The number of signatures required is $10 \%$ of the electorate in Croatia and Latvia, whereas in six other countries it is a fixed number of signatures. ${ }^{17}$ In Latvia, constitutional amendments are optional on certain articles, if requested so by one-tenth of the electorate and if those amendments are not adopted accordingly by parliament. Four other countries require the consent of the parliament or the president. In Bulgaria and Montenegro a parliamentary majority is required, whereas in Romania, Serbia, and Slovenia collecting enough signatures suffices to initiate a popular vote. The final decision remains with the President (calling a mandatory referendum in Romania) and the parliament (Serbia, Slovenia), respectively. 
Eighteen countries provide for popular initiatives on issues of national importance. In all cases, this requires just a minimum number of signatures to be collected within their respective time limits. In Italy, San Marino, Liechtenstein and Switzerland also a number of sub-national councils may call such a referendum. Furthermore 500,000 voters or five Italian Regional Councils may request to (partly) repeal a law (excluding treaty ratification) by referendum. The same applies to San Marino, albeit with 1.5\% of the electorate or five municipal councils. In Liechtenstein, the parliament, 1,000 citizens or three municipalities can trigger a referendum on a law passed by parliament. In contrast, $10 \%$ of the Latvian electorate can trigger a referendum unless this is overruled by three-quarters of the MPs. Popular initiatives in Bulgaria, Montenegro, Poland and Portugal also demand a parliamentary majority. Between 1989 and 1997 Portugal had excluded treaty referendums, but now permits popular initiatives on such issues by which parliament must give its consent. 75,000 signatures (requesting the MPs to hold a referendum, after preventive judiciary review of constitutionality and legality) permit the president to take a discretionary decision with respect to the holding of a referendum (Gouveia 2011: 78). Portuguese referendums on international agreements though are possible only on such important issues that concern the national interest.

In 14 countries the referendum rules on issues of national importance also apply to popular initiatives on treaty ratification, transfer of powers and joining international organisations. Liechtenstein and France have some additional hurdles. In Liechtenstein 1500 signatures (instead of 1000) or the support 4 municipalities (instead of 3 ) is needed, and in France, one-tenth of the electorate has to be supported by at least one-fifth of the National Assembly. Nevertheless, it is striking to note that five countries (Austria, Romania, Spain, the UK and Slovenia) explicitly exclude popular initiatives on international treaties, whilst they allow for referendums on these issues if decided so by parliament or government. ${ }^{18}$ In Austria popular initiatives are limited to federal matters, and in Finland to 'issues the parliament has the power to address'. Romania and Spain exclude popular initiatives on international matters. The United Kingdom excludes popular initiatives by stating that a referendum may only be called by an Act of Parliament.

\subsection{The practice of EU-related referendums}

The 61 EU-related referendums that actually took place were called for very different reasons. As Figure 3.1 shows, most referendums were constitutionally required. This means that the negotiating government is aware of the fact that pursuing its policy objective requires a (binding) referendum. The second most frequent trigger is when citizens initiate a referendum in order to seek to change the (envisaged) policy. Governments both held referendums for reasons of empowerment or of appropriateness, while parliaments (or at least some political parties) also triggered referendums for mediating reasons. Figure 3.1 also shows that parliaments did opt more often for referendums for reasons of appropriateness than governments did, although often governments proposed parliaments to organise these. Citizens have triggered referendums always for policy-seeking motives, aiming to either 
promote a new initiative, or to reverse a proposal which has been adopted by political actors. A detailed overview of the overriding reasons of the practice of EU-related referendums is provided in Table 3.3.

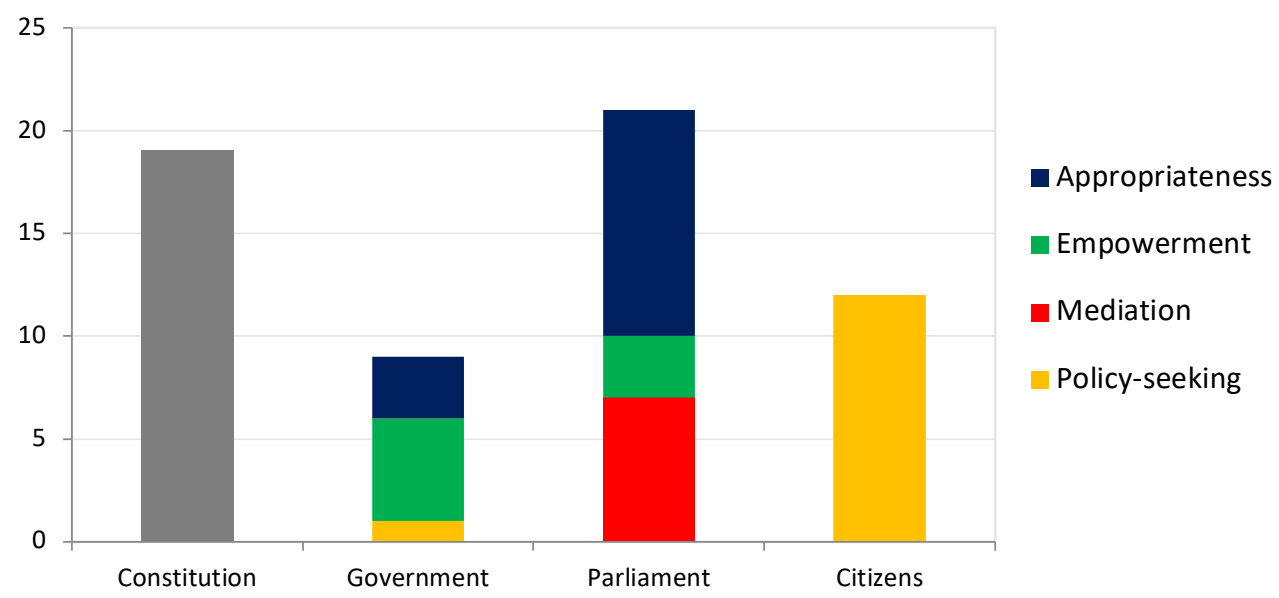

Figure 3.1. Overriding reasons per actor to trigger EU-related referendums $(\mathrm{n}=61)$.

Table 3.3. Overriding reasons per actor to trigger EU-related referendums (specified per case).

\begin{tabular}{|c|c|c|c|c|}
\hline Reason & Constitution & Government & Parliament & Citizens \\
\hline Mandatory & $\begin{array}{l}\text { AUS1994, CRO2O12, } \\
\text { DEN1972, DEN1992, } \\
\text { DEN1998, DEN2000, } \\
\text { DEN2014, EST2003, } \\
\text { IRL1972, IRL1987, } \\
\text { IRL1992, IRL1998, } \\
\text { IRL2O01, IRL2002, } \\
\text { IRL2008, IRL2009, } \\
\text { IRL2O12, LAT2003, } \\
\text { ROM2003 }\end{array}$ & & & \\
\hline Appropriateness & & $\begin{array}{l}\text { LUX2005*, } \\
\text { SPA2005*, } \\
\text { POL2003* }\end{array}$ & $\begin{array}{l}\text { CZE2OO3 }^{* * *}, \\
\text { DEN1993, } \\
\text { HUN2OO3***, } \\
\text { LIE1992, LIE1995, } \\
\text { LIT2OO3, } \\
\text { NET2005, } \\
\text { SLK2003, } \\
\text { SLO2003, } \\
\text { SWI1972, } \\
\text { SWI1992 }\end{array}$ & \\
\hline
\end{tabular}




\begin{tabular}{|c|c|c|c|}
\hline Empowerment & $\begin{array}{l}\text { FRA1972, } \\
\text { FRA1992, } \\
\text { FRA2005, } \\
\text { GRC2015*, } \\
\text { HUN2O16* }\end{array}$ & $\begin{array}{l}\text { DEN2015, } \\
\text { GRE1982, } \\
\text { MAL2OO3 }\end{array}$ & \\
\hline Mediation & & $\begin{array}{l}\text { FIN1994, } \\
\text { GBR1975*, } \\
\text { GBR2016*, } \\
\text { NOR1972*, } \\
\text { NOR1994**, } \\
\text { SWE1994, } \\
\text { SWE2003 }\end{array}$ & \\
\hline Policy-seeking & DEN1986* & & $\begin{array}{l}\text { ITA1989, } \\
\text { NET2016, } \\
\text { SMR2013, } \\
\text { SWI1997, } \\
\text { SWI2000, } \\
\text { SWI2001, } \\
\text { SWI2005a, } \\
\text { SWI2005b, } \\
\text { SWI2006, } \\
\text { SWI2009a, } \\
\text { SWI2009b, } \\
\text { SWI2014 }\end{array}$ \\
\hline
\end{tabular}

* government proposed, parliament triggered

${ }^{* *}$ also de facto obligatory (appropriateness)

${ }^{* * *}$ especially designed constitutional amendments; hence de facto parliament enabled to trigger these 'mandatory' referendums

\subsubsection{Mandatory EU referendums}

Of the 22 countries providing for mandatory referendums on EU issues, so far eight countries were required to hold them. All eight countries required referendums on their prospective EU membership (either because of constitutional amendment or because of joining an international organization). Figure 3.2 shows that most of these mandatory referendums took place in Ireland (9) and Denmark (5). Why is this the case for these two countries? The country-specific circumstances can shed some light on this: in Ireland these dealt with the incorporation of the EU issue by constitutional amendments which required a referendum; while in Denmark that these EU issues required a five-sixth parliamentary majority that was not obtained. 


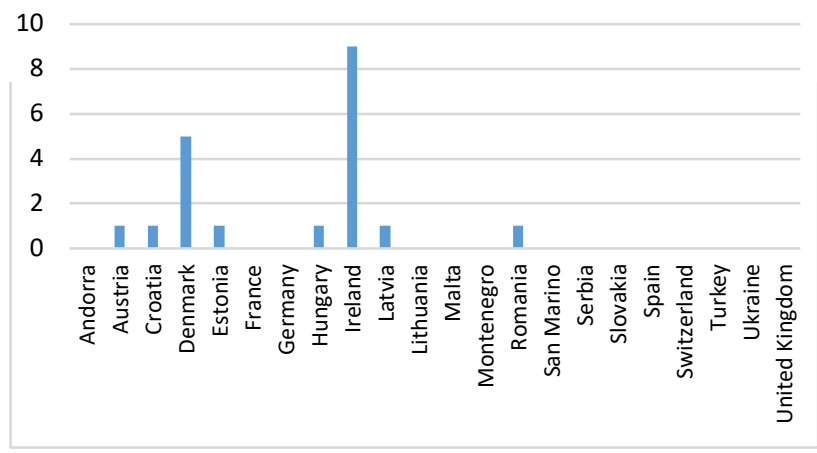

Figure 3.2. Practice of mandatory EU referendums in countries providing for them.

Constitutional amendment. Ireland created its referendum tradition mostly due to a Supreme Court judgment in the Crotty v. An Taoiseach case in 1987. The Irish government had agreed in 1986 to the adoption of the Single European Act (SEA) on the assumption that this would not require a referendum but could be secured by a vote in the Dáil (lower house). The anti-integration campaigner Raymond Crotty challenged this assumption successfully at the Supreme Court: it ruled that a referendum was required when the essential scope and objectives of the EC were extended. According to the Court, this was the case because the SEA contained a transfer of sovereignty to an international organisation, particularly regarding the clause about European Political Cooperation. Ever since then the ratification of the revised EU treaties was considered to require a constitutional amendment and therefore automatically an obligatory and binding referendum. The Supreme Court did not assess though whether these subsequent treaties had already been covered by existing constitutional provisions (Massüger and Kuoni 2011: 147). It set a precedent for new EU treaties that ratification of the SEA would not be compatible with the Constitution as it stood. Hence, also the Maastricht and Amsterdam Treaties were subject to referendums initiated by 'international imperative'. These secured a safe popular majority until the process got stuck at Nice and Lisbon, on which the Irish citizens voted twice after a first rejection.

Missing the required parliamentary majority. In Denmark the reasons for the referendums were less sequential. Normally the basic condition for evading a referendum (on treaty ratification) which entails a transfer of powers is by obtaining a five-sixth majority of all members of the Folketing. On the one hand, the referendums on EC accession, on the Amsterdam Treaty and on EMU accession were constitutionally triggered because this required five-sixth parliamentary majority was not reached. On the other hand, the referendum on the Maastricht Treaty considered such a considerable transfer of competences that the $\oint_{20}$ of the Danish Constitution required a referendum. Despite of the large parliamentary majority in favour of the Maastricht Treaty, the Danish voters rejected it by a narrow majority of $50.3 \%$. In contrast to the first Maastricht referendum in 1992, in 1993 a five-sixth majority was obtained. However, as a result of the 'National Compromise' (see section 6.4.2), all parties agreed that a 
second referendum was necessary anyway and hence it was triggered by parliament instead. Part of the National Compromise of 1992 was that a decision whether to join the Economic and Monetary Union would be taken later on. In September 2000, the Folketing adopted the bill empowering Denmark's accession to the Euro, but it did not obtain the required five-sixth majority. Therefore, a referendum was mandatory (Massüger and Kuoni 2011: 152). The vote resulted in a rejection by $53.1 \%$. Denmark opted-out from EMU.

\subsubsection{Optional EU referendums}

Triggered by governments. As discussed in section 2.3.2, governments have several motives to trigger optional referendums: to reinforce their power, to circumvent an opposing parliamentary majority, to resolve rifts within the government or governing parties, or to underline the importance of the issue, as a reason of appropriateness.

Empowerment. The French government has used the referendum mechanism to reinforce its power several times: on the 1973 round of EC enlargement, on the 1992 Maastricht Treaty and on the 2005 Constitutional Treaty (CT). In all three cases, it was a matter of presidential prestige to acquire popular confirmation of the government's policy. French President Mitterrand's decision to hold a referendum on the Maastricht Treaty was based on his reckoning that it would undermine his political opponents. In 2002 Mitterrand's successor President Chirac also promised a referendum on the CT but then postponed the final call until he had no alternative after a British referendum had been announced. The transnational repercussions of the British call meant that there was no way back. Also the Greek 2015 'bailout' referendum was triggered by Prime Minister Tsipras for powerreinforcing reasons: not in order to obtain a majority, but rather to block a draft agreement between the EU Finance Ministers, the European Commission and the IMF. The Greek government used it as an instrument to secure its survival in parliament and to retain political credibility with the Greek people. In the same way, Hungarian Prime Minister Orbán tried to strengthen his opposition against the 2015 Council of the EU's decision on the quota of migrant resettlement. The legality of a referendum on this decision was disputed because it dealt with an 'obligation arising from an international agreement' which are excluded from referendums under Hungarian law. However, the question was framed such that it asked the citizens' opinion whether the EU should be empowered to resettle migrants in Hungary 'even without the approval of the National assembly'. Despite huge government propaganda and an overwhelming 98 percent voting support for Orbán's view, the turnout quorum of 50 percent was not reached. The pro-EU centre left parties had called for a boycott of the vote, indeed arguing that it was only there to support Orbán's partisan goals, and were successfully supported by a group of activists that called to the people to spoil their ballots in protest (Batory 2018: 265). Consequently, the outcome was invalid.

Policy-seeking. As the Danish government initially could not secure a parliamentary majority on the Single European Act in 1986, it proposed a referendum instead of calling 
a general election. The coalition parties promised that they would vote according to the referendum result (Hug and Sciarini 2000: 14). Also in 2005 the Danish government had no other choice than opting for a referendum on the Constitutional Treaty because the necessary five-sixth parliamentary majority was not met (Laursen 2009). In addition, the Czech and Polish governments pledged for a plebiscite on the CT because they were not sure that the required parliamentary majority was reached (Oppermann 2013a: 75). In the Czech Republic, the government coalition led by Social Democrats faced strong opposition from the Civic Democrats, the Communist Party and most notably President Klaus who refused to sign the treaty. In Poland, also the Law and Justice party and the League of Polish Families parties demanded a referendum. In both countries, however, the support rates for the CT dropped that dramatically that a positive outcome would have been questionable, if the referendums were held.

Mediation. Internal pressures within the governing parties had caused the British membership referendums in 1975 and in 2016. In 2004 they also forced British prime minister Tony Blair to announce a referendum on the CT, giving in to the Eurosceptics in his Labour Party (Closa 2007: 1318-21). Blair prevented that the issue would divide the Labour Party from adversely affecting the EP elections of 2004 and the general elections of 2005. Moreover, Blair neutralised the opposition which had been demanding a referendum referring to other countries which had already committed to do so, and expected constraints in the House of Lords without the call for a referendum being attached to the proposal. Back in 1975 the UK's membership referendum had been the result of Labour's return to government with Prime Minister Wilson. The Labour manifesto committed the new Labour government to a referendum on whether Britain should stay in the Common Market on renegotiated terms, or leave the EC (Gay and Miller 2013). In 1971 after some Labour MPs had supported the EC membership Bill in parliament and consequently the Labour Party failed to defeat it, the Labour leadership pressed for a referendum. In order to prevent a party split, Wilson even allowed individual ministers opposed to EC membership to speak out against the government during the campaign (Gifford and Wellings 2018: 270). For a long time the British government could shield itself against the demand to hold another referendum on EU membership. The 2016 'Brexit' referendum was promised by Conservative Prime Minister Cameron in 2013 (after strong calls by over 100 Eurosceptic Conservative MPs and a growing UK Independence Party which threatened Conservative backbenchers in their marginal seats). The question of EU membership was immediately tabled as an Act of Parliament by the British government after Cameron was re-elected in 2015 . In effect, Cameron's commitment can be viewed as the culmination of a Eurosceptic referendum campaign that had been under way since the cumbersome ratification of the Maastricht Treaty in Britain. Margaret Thatcher, who had been ousted from as Prime Minister by the Conservative leadership contest in 1990 on her European leadership, argued during the Commons debate that anyone who 'does not consider a referendum necessary must explain how the voice of the people shall be heard'. After the Danish 'No' Thatcher's successor John Major had to defend parliamentary sovereignty against opposing Labour calls for a referendum. The several campaigns for a referendum in 1992-1993 rested on considerable 
cross-party support, ranging from Eurosceptic Conservatives, Labour prominent Tony Benn to Liberal Democrat leader Paddy Ashdown (Batory 2018: 273). Like Wilson in 1975, Cameron gave his cabinet members a free vote on Brexit instead of asking for collective support of the Remain case.

Appropriateness. Due to the 'overriding importance' of the issue in 1972 the Swiss government proposed the Swiss parliament to hold a referendum on the EC-EFTA Treaty and it did the same in 1992 on the envisaged accession to the European Economic Area (EEA). About 2005, the governments of the countries which planned to hold a referendum on the Constitutional Treaty appealed to the different nature of the CT compared to previous stages in the European integration process. The governments in Spain, France, Portugal, Poland, the Netherlands and Luxembourg reasoned that it required direct legitimation and great popular support. The same argument had been used by the Polish and Maltese governments concerning their accession referendums in 2003.

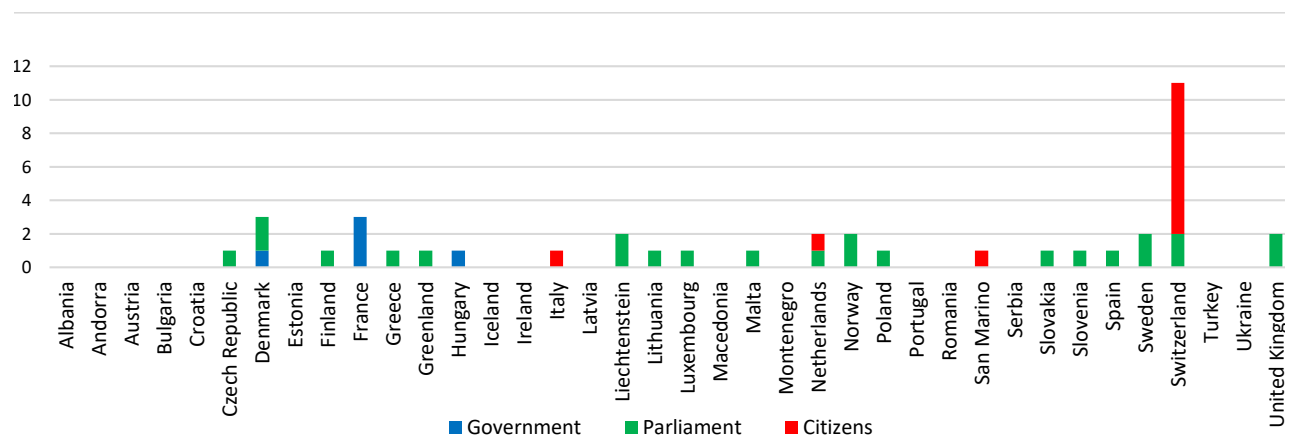

Figure 3.3. Practice of optional EU referendums in democratic countries providing for them (per actor).

Figure 3.3 illustrates the number of optional referendums per country and by which actor they were triggered. It shows that only the French president and the Danish and Hungarian governments utilised their executive power of calling a referendum (apart from the times that governments proposed referendums to parliament). An explanation for this limited number could be that governments avoid referendums if these would bring more constraints to the ratification process compared to the parliamentary procedure. Governments prefer parliamentary ratification whenever this strategy maximises their probability for saving the treaty gains. Many Central and Eastern European governments reasoned this way when facing the ratification of the Constitutional Treaty, the Lisbon Treaty and the Fiscal Compact. These governments neither used the referendum as a threat during these treaty negotiations. This was due to domestic constraints on the instrument itself: a combination of high turnout and approval quorums, a sceptic public opinion and long-lasting legal requirements to repeat invalid referendums.

Triggered by the parliament. Besides the constitutional obligations and the deliberate choice of governments to call for popular votes, also national parliaments have 
many initiated EU-referendums, even when these were not strictly necessary.

Mediation. A first motive for political parties for calling referendums is to masque their internal political division on an issue. The British and Scandinavian parliaments exemplify this argument. Both British referendums on EC/EU membership marked (high) internal divisions within the governing parties as well. The Norwegian parliament twice decided for a referendum on EC or EU accession, in 1972 and 1994, respectively. The referendums were chosen in order to convince the required three-quarters parliamentary majority, which was uncertain both times. The timing was deliberately chosen by parliament in order to maximize chances for approval. But in both cases, the ruling Labour Party was marked by internal divisions. A majority of the Norwegians rejected EU membership. Political division also triggered the Finnish EU accession referendum in 1994. For the incumbent Centre Party, a referendum was the only possible method to decide on the issue given that a clear majority of its supporters opposed entering the EU. Only the incumbent Conservatives had an unambiguously positive attitude towards EU membership and could count on most of their supporters. The Finnish constitution specifies that each optional referendum must be provided for by an act of parliament, which can hold a referendum on any issue. Such an act enabled the referendum on Finnish EU accession in 1994 (Gallagher and Uleri 1996: 53).

The two Swedish referendums on EU membership (1994) and joining the Euro (2003) had to cope with intra-party rifts as well. Already in 1990, the Social Democratic government had unexpectedly announced to apply for membership. This move was endorsed by three bourgeois opposition parties (Conservatives, People's Party and Centre Party), but the Left and Environmental Party immediately spoke out against membership and requested a referendum, as well as Conservative leader Carl Bildt. Two problems emerged: the internal (social-democratic) party division and the fact that the conclusion of the accession negotiations coincided with the general election of autumn 1993, which made the outcome highly uncertain. A compromise was reached that the consultative referendum would take place six weeks after the elections on the proposal 'Yes or No to membership based on the agreement reached in Brussels' (Gallagher and Uleri 1996: 171). In this way, the necessary revision of the Swedish constitution was not put to a (semi-mandatory) direct vote but circumvented by a double election. Soon after Sweden entered the European Union, the issue whether Sweden would join the single currency became a hot potato for the government. The decision to decouple Swedish EU and EMU membership made another referendum likely but far from certain. Sweden has had neither a political need for referendums on treaty reform, nor a constitutional requirement. So referendums were not deemed necessary for ratification of the Amsterdam and Nice treaties. However, at an extraordinary party congress in 2000, the Social Democratic leadership was forced into granting a referendum in order to secure an EMU-positive congress resolution. This was supported by all parties except the conservative Moderates (Sitter, 2009, p.90). In 2002 the parliamentary parties agreed to hold the referendum in 2003. Despite wide parliamentary support, the Swedes rejected the proposal to join EMU. The opposition could easily exploit the symbolic role of the national currency (see also section 6.3.3). 
Appropriateness. A second reason that parliaments often opt for referendums, is to underline the (national) importance of the issue. Therefore, it is not surprising that most of these referendums dealt with membership issues, such as the accession referendums of Liechtenstein to the EEA (in 1992 and 1995) or of the five CEECs in 2003 (the Czech Republic, Poland, Slovenia, Slovakia and Lithuania). "[A]ll the referendums except Malta's were inherently likely to be symbolic demonstrations of the united will of citizens emancipated from communist rule and determined to return to the Europe of which they felt they should always have been part" (Henderson 2004: 659). This stipulates that the referendums in the CEECs were triggered by a pro-forma argument that it was appropriate to hold them. To enable EU accession, Slovenia included a new article in its constitution according to which parliament may call for a referendum on a transfer of sovereignty to international organisations or defensive alliances (i.e. to the EU and NATO).

In Greenland, Malta, the Netherlands, Norway and Switzerland, ad hoc laws have been adopted to provide for referendums on issues of national importance. As discussed above, in Norway EC/EU membership referendums took place on (ad hoc) parliamentary decisions, without being mentioned in the Constitution or in a separate law. In Greenland (after it had gained autonomy from Denmark in 1979), the 'independent' regional parliament called for a referendum in 1982 in order to bolster its wish of leaving the EC, albeit without a clear legal base (Massüger and Kuoni 2011: 135). So the referendum in Greenland to leave the EC was held by means of an ad hoc parliamentary decision. In the Danish 1972 accession referendum, an overwhelming Greenlandic majority had voted against EC membership. Greenland was the first country to leave the Community by 1985 (and until the envisaged British departure from the EU the only one). Its exit was motivated by the wish to protect Greenland's fishing industry and to minimise the outside interference from Denmark and the EEC (Schneider 2018: 420).

For reasons of appropriateness, some parliaments also took recourse to referendums on treaty ratification. As a consequence of the narrow Danish No on the Maastricht Treaty in 1992, the Danish political parties constituted the so-called 'National Compromise' demanding Danish exemptions on the issues of a common European foreign policy and common defence, a common currency, and supranational decision-making on Justice and Home Affairs and Union citizenship. The Danish government's demands were accepted during the Edinburgh European Council (Petersen 1998: 10-11) and would be approved by means of a second referendum (which was itself part of the compromise and as such de facto obligatory; see also section 6.5.2). This despite the fact that reaching the National Compromise implied that the constitutionally required five-sixth majority was already secured. In May 1993 the Danish people agreed on the Maastricht Treaty by a second referendum. Because of the Danish optout on Justice and Home Affairs, the Folketing committed the new (minority) government in 2015 that it should organise a referendum on an opt-in on a reform of these issues and Europol. Like they did in 2000 by rejecting EMU-membership, the Danes maintained their opt-out. In the Netherlands, the parliamentary desire to have a referendum on the Constitutional Treaty had to be enabled by a special law. Although the Christian Democratic-Liberal government 
did not support the parliamentary initiative for a referendum on the Constitutional Treaty, it would implement it and respect its outcome. Despite of the consultative nature, in practice a consensus progressively emerged amongst almost all the main political parties that the result would be respected. After a fierce campaign, the Dutch electorate massively rejected the treaty by 63 percent (Harmsen 2005: 1-3). As a result, the official treaty was taken off the parliamentary agenda.

Triggered by the citizens. Optional referendums in the form of popular initiatives and popular vetoes are an almost exclusively Swiss phenomenon. Nine out of twelve of these referendums took place in Switzerland. One reason for this frequency is that the threshold for popular initiatives is relatively low (50,000 signatures vis-à-vis the relatively modest Swiss population). Secondly, Europe is a contested policy area, where referendums can express citizens' constraining dissensus on European integration. A third explanation could be that Switzerland does not exclude international issues from a popular vote.

Three Swiss popular initiatives dealt with the relationship between Switzerland and the EU. Whereas the 1997 initiative contained a proposal that the Ständerat (Senate), instead of the Bundesrat (Government) should decide about the opening of EU accession negotiations, the 2001 initiative proposed Swiss participation in the European integration process, strived for EU membership and forced the immediate start of accession negotiations. Both initiatives where dismissed by the Swiss government and rejected by the Swiss people. In contrast, the 2014 popular initiative on 'mass migration' aiming at downscaling the Swiss-EU bilateral agreements on free movement rights, obtained a slight popular majority, despite the broad rejection of the initiative at political and mainstream societal level (see section 6.4.2).

The six Swiss popular vetoes dealt with one treaty (bilateral agreements between the EU and Switzerland) and several policy issues. These latter issues varied from accession to the Schengen area (2005) and subsequent introduction of biometric passports (2009), to extending free movement rights to citizens of acceded CEECs (2005 and 2009), and cooperation with countries in Eastern Europe (2006)v. Interestingly, all these 'popular vetoes' failed because a majority of the voters supported the Swiss government.

Besides the Swiss votes, an Italian popular initiative of 114,000 signatures called for a consultative guideline-referendum on conferring a mandate on the European Parliament to create a European Constitution (Erne 2004). The Italian parliament, willing to support the initiative, adopted an ad hoc constitutional law to enable the organisation of this referendum at the same day of the European Parliament's elections. A great majority of Italians answered 'Yes'.

The 2013 referendum of San Marino is somewhat complex. When a popular initiative was launched calling for the start of accession negotiations, the government did not react enthusiastically. The initiators won the referendum by 50.1\%. However, the result was invalid because the approval quorum was not reached due to a low turnout of only 32 percent. Consequently, the government could continue its policy of closer cooperation with the EU, 
without the prospect of accession.

In 2015, also the Netherlands enabled popular initiatives on bills, including international treaties. As a consequence, a non-binding, referendum was triggered in 2016 on the in 2014 signed Association Agreement between the EU and Ukraine. Over the summer of 2015, the private initiative GeenPeil mobilised about 400,000 citizens to support the final referendum request on the contested relationship between the EU and Ukraine. The turnout threshold of $30 \%$ was just met: $32 \%$ of the electorate showed up of which $61 \%$ voted against the agreement. After some skilful negotiation in Brussels and domestically, the Dutch government mastered to adopt an additional Declaration within the European Council, after which the Dutch parliament was eventually willing to ratify the agreement. However, at the time of writing, there is a bill pending in parliament to repeal the Advisory Referendum Act (see section 6.4.2).

\subsection{Referendums that never occurred}

After unfolding which EU-related referendums took place and why these were triggered, it is also worthwhile to look at referendum cases that never made it to the voting booths. It shows that the discussion on referendums is embedded in a broader context than in just the countries that organised referendums. The first reason for this is that there was insufficient parliamentary support because the government was backed by a unified front in parliament to block attempts triggering a vote. The second reason was that the government found institutional bodies on its side that a referendum on the EU-issue was not necessary or not allowed, for instance because it was excluded by the national (constitutional) court. Instead of triggering referendums, those in power often try to use defensive mechanisms as a form of risk management to cope with the uncertainty caused by referendums. Avoiding referendums is hence a preventive strategy (Papadopoulos 2001: 37). Each argument is unfolded as follows.

\subsubsection{Referendum avoidance}

There were serious calls for referendums ratifying the 1992 Maastricht Treaty in many member states, albeit mostly from opposition quarters. In Belgium and Germany these calls lacked parliamentary support, in other countries the opposition was also too weak. While the Amsterdam Treaty had been subject to a Danish referendum due to a transfer of sovereignty and the missing 5/6 parliamentary majority, it was argued that the Nice Treaty did not include such a transfer of Danish sovereignty. Hence, a referendum could be avoided. The Folketing adopted the Nice Treaty by 98 to 14 votes. Besides the four referendums on the Constitutional Treaty in Spain, France, the Netherlands and Luxembourg, eight other countries announced and prepared referendums on the CT: Belgium, Denmark, the Czech Republic, Finland, Ireland, Portugal, Poland and the UK. Though, apart from Ireland, domestic ratification provisions for treaty reforms did not require these popular votes. The Belgian government had originally 
announced a referendum but finally followed parliamentary ratification. Similarly, Finland also announced a referendum but finally followed parliamentary ratification, when the Justice Minister mooted the possibility of a consultative referendum. The Constitutional Law Committee, however, did not consider this necessary and all three governing parties, along with the main opposition party spoke out against. (Finke and König 2009: 350). However After the French and Dutch 'No', the remaining planned referendums on the CT were shelved.

Avoiding new referendums became the leitmotiv for the position of some governments, despite calls from opposition parties for a referendum on any alternative treaty (Closa 2007: 1317-27). Ireland was the only country to hold a mandatory referendum on the Lisbon Treaty, the alternative of the Constitutional Treaty. How did so many countries manage to avoid new referendums, given the similarity between the Lisbon Treaty and the Constitutional Treaty? Oppermann argued that three factors were crucial for avoiding the referendum conundrum: collusion between governments, domestic political changes, and governing strategies of depoliticisation (Oppermann 2013a: 77-85). Given the fact that no institutional changes took place, the reasons for (not) holding referendums on the CT were mainly actor-based. The Spanish and Luxembourg governments argued that since their voters already had endorsed the CT and the Lisbon Treaty was considered similar in most significant respects, a second vote on the same treaty was considered unnecessary and uncontested. France and the Netherlands found themselves in the opposite position as their voters had rejected the Constitutional Treaty. Hence the French and Dutch governments argued that the Lisbon Treaty was too modest and sufficiently different from the CT, which justified not to hold another referendum. The new French president Sarkozy ignored calls for a referendum. Also Poland, the Czech Republic, the Netherlands and the UK faced new governments which could easier get away with their preference for parliamentary ratification. The decisions of the Czech and Polish governments not to hold referendums on the Lisbon Treaty were uncontested. In Portugal, given the broad pro-Lisbon treaty consensus between mainstream parties and in society, the referendum demanded by some opposition parties was blocked in parliament. Also large member states explicitly put pressure on the Portuguese executive not to endorse a vote (Oppermann 2018: 251). Similarly, the UK departed from its preceding referendum commitment to the Constitutional Treaty, on grounds that the Lisbon Treaty lacked the constitutional dimension possessed by its predecessor. Nevertheless, the government had to resist strong pressure for a referendum led by the Conservative party, Eurosceptic newspapers and some Labour MPs (Oppermann 2013a: 75-6). When gaining office in 2010 Prime Minister Cameron accepted the Lisbon Treaty, arguing that the only alternative under EU law was to withdraw from the EU. This triggered Eurosceptic Conservatives to campaign for a referendum whether the UK should leave the EU (Rose 2018: 15). In the meantime also the saliency of the issue had decreased.

Some other referendums, unrelated to European treaty ratification, were avoided as well. In Bulgaria and Iceland political support lacked in parliament for holding membership referendums. Since the Icelandic government has de facto suspended the accession negotiations in 2013, a referendum in the near future is out of the question. In Norway, an 
attempt to hold a referendum on the EEA agreement was blocked in parliament, which was ratified by the required parliamentary majority instead. In 2011 Greek prime minister Papandreou proposed a referendum on the ' $50 \%$ haircut conditions' to rescue the country from its sovereign debt crisis. He quickly reneged his promise after huge international and domestic pressure and was forced to resign. In some CEECs Eurosceptic voices demanded a referendum on the introduction of the Euro. In Latvia, which adopted the Euro in 2014 without a referendum, only a handful MPs called for one. In the Czech Republic, the government resisted pushes for a referendum by opponents of the Euro, while in Poland the government reluctantly accepted to hold a popular vote, which can be considered as part of a delaying tactic (Batory 2018: 264). Both countries are not expected to introduce the single currency soon.

\subsubsection{Anti-referendum advises}

By means of 'judicial depoliticisation' the government invoked legal advice of institutional bodies supporting its stance against referendums. It is remarkable that in Denmark the Ministry of Justice has extraordinary discretionary powers in its analysis determining whether a treaty change involves a transfer of sovereignty or not. In Belgium, Sweden and the Netherlands, the semi-executive Council of State could play a prominent role. In the Netherlands, the Lisbon Treaty was considered a regular reform treaty, like the preceding Treaties of Maastricht, Amsterdam and Nice. Although some parties called for a referendum in 2007, a parliamentary majority finally decided that a consultative referendum on the Treaty was not necessary, after the Council of State advised that there is no legal need for a referendum because the new treaty did not include 'constitutional' elements (Oppermann 2018: 252).

Like in the Dutch case, also the Swedish Law Council concluded that there were no constitutional obstacles against parliamentary ratification of the Lisbon Treaty under the transfer of powers clause. Legally, the Danish concerns on sovereignty issues were probably the most difficult to overcome without a referendum. The government's pre-emptive strategy requested that nine issues from the original CT be removed. Eventually these concerns were sufficiently accommodated during the negotiations to enable the Ministry of Justice to conclude that the Lisbon Treaty did not amount to a transfer of sovereignty requiring a referendum (Closa 2013: 77). In this way the negotiations strengthened the British, Danish, Dutch and French governments' positions against the referendum demands.

\subsubsection{Anti-referendum rulings}

It is important to take note of the growing amount of litigation on membership and treaty referendums. Although the unconstitutional ratification of the SEA was (successfully) challenged in Ireland, in other cases judicial recourse did not secure a referendum (or just 
prescribed procedurally more rigorous referendums: in Denmark, Estonia and Latvia on accession and in Denmark on the Maastricht Treaty). Other referendum calls were dismissed in court, such as initially in Estonia and Latvia on the question of membership (Albi 2005: 158). Portugal had a constitutional bar on treaty ratification referendums until in the $1990 \mathrm{~s}$ a constitutional amendment enabling these referendums entered into force. However at the time of the ratification of the 1997 Amsterdam Treaty, the Constitutional Court's approval for the amendment was unforthcoming. Hence at that time, the 'old' constitution was still in force and the referendum could not be held. Moreover, the proposed referendum question was judged to be too vague by the Constitutional Court (Hug 2002).

In Austria, the Constitutional Treaty gave rise to controversy on the need of a total constitutional revision and an accompanying referendum. However, this challenge was rejected by the Constitutional Court on standing grounds (Mendez et al. 2014: 38,48). The Lisbon Treaty was challenged in the Czech Republic, Denmark, Germany, Latvia and the UK (Closa 2013). In Germany, also the ESM and Fiscal Compact were challenged for not holding a referendum on the issue (Mendez et al. 2014: 68). This shows that the demand for referendums on EU matters goes beyond the existing cases and even spreads across countries which have not provided for them by law (e.g. Germany).

In the UK a legal challenge on the parliamentary decision not to hold a referendum on the Lisbon Treaty was rejected by the High Court, after which the government could conclude the ratification process in 2008 (Mendez et al. 2014: 55-63). Other constitutional challenges in Austria, Estonia and Latvia and Greece for failing to use the referendum instrument on the ratification of the Lisbon Treaty and the ESM Treaty were rejected by national courts or missed sufficient parliamentary support. In 2015 the Greek Council of State dismissed a case brought by the Greek opposition parties claiming that the referendum called by the Greek parliament on the EMU bailout package was invalid because 'issues of national importance' ought not to include public finances.

\subsection{Conclusion}

This chapter researched which referendums were held on European integration. The findings reveal that the regulations in 37 countries (out of 43) currently provide for potential referendums on European integration. Six countries do not regulate national referendums (Belgium, Bosnia and Hercegovina, Greenland, Cyprus, Monaco and Norway). This does not necessarily mean that referendums are not possible in those countries. Greenland and Norway organised EU-related referendums based on ad hoc legislation. In Central and Eastern European countries constitutions were amended to either require membership referendums (Hungary), or to provide for it (Czech Republic, Poland, Slovenia, and Slovakia). 19 countries require a referendum in case of constitutional amendments, while 11 (partly the same) countries require referendums on any (future) transfer of powers to or on the membership of international organisations such as the EU. In Denmark this obligation is lifted if five-sixth of 
parliament approves the transfer of powers.

The variety among optional referendums on EU issues is much larger. Particularly parliaments have many opportunities to organize referendums on matters related to the EU. In five countries the government can enforce a referendum autonomously. In other countries the government can propose to parliament to organise a referendum on issues of national importance.

To a lesser extent citizens can enforce popular initiatives. It is remarkable though that six countries which provide for referendums called by their parliaments, at the same time prohibit popular initiatives on EU-related issues. As 11 out of 22 countries do not explicitly exclude popular initiatives (i.e. referendums called by citizens) on treaty ratification, the practice of these popular initiatives on treaties has been mainly limited to Switzerland. The threat for a referendum pushes the Swiss political establishment to reach broadly supported compromises, which can withstand a popular veto. Even countries with a rich referendum history like Denmark and Ireland do not provide for popular initiatives on EU matters. Moreover, the number of to be collected signatures is rather high in general (sometimes 10 percent of the electorate or even more).

The 61 EU-related referendums were mandatory, or triggered by the government, by the parliament or by popular initiatives. This number of 61 referendums seems considerable, but compared to the legal opportunities that parliaments and citizens have, this is a modest number over the last 45 years. A first reason for this are the limited possibilities for popular initiatives on EU matters. A second reason is that governments or parliaments were not pushed to hold referendums, because they could secure their policy objectives through representative democratic mechanisms. A third reason is that governments considered some suggested referendums as a risk. Nevertheless, also EU-related referendums could be expected in the 15 countries which did not hold these referendums yet, for instance when candidate countries such as Macedonia, Montenegro and Serbia intensify their integration into the EU and need to legitimise this integration by direct democratic approval.

\section{Appendix: Constitutional and legal provisions}

\section{Notes}

1. Laws in Albania, Andorra, Bulgaria, Greece, Hungary, Montenegro, Poland, Slovakia and Spain explicitly envisage a role for the government. In Austria, Czech Republic, Denmark, Estonia, Finland, Greenland, Iceland, Latvia, Liechtenstein, Lithuania, Luxembourg, Macedonia, Malta, the Netherlands, Norway, San Marino, Serbia, Sweden, Switzerland, Ukraine and the UK, the government may ask parliament to pass such (ad hoc) referendum legislation.

2. The minority of MPs who can trigger a referendum is in: Austria 1/3; Italy 1/5; Luxembourg 1/4; Slovenia 1/3; Spain 1/10; Sweden 1/3.

3. Some countries prohibit referendums with the purpose of discharging them from certain treaty obligations (e.g. Denmark and The Netherlands). 
4. 500,000 or 5 regional councils are necessary in Italy to enforce a popular vote, 1500 or 4 municipalities in Liechtenstein, 25,000 in Luxembourg, 350,000 in Slovakia, 100,000 in Switzerland and 3,000,000 in Ukraine spread at least 100,000 among two-thirds of the regions. In Italy, however, the referendum shall not take place when the constitutional amendment is adopted by a two-thirds majority after the second reading in parliament.

5. Andorra, the Czech Republic, Denmark, Greece, Iceland, Ireland and Luxembourg implicitly exclude popular initiatives by only regulating plebiscites.

6. In Denmark, Ireland, Austria, Estonia, Hungary, Latvia, Romania and Croatia. In Austria, a referendum due to a total revision of the constitution was deemed necessary for its EU accession in 1994 (Mendez et al. 2014: 47). Although referendums are not required on matters such as EU accession according to the Estonian Constitution, constitutional amendments had to be introduced to accommodate EU membership. Indirectly, a referendum was thus constitutionally required.

7. By passing this threshold for the subsequent Treaties of Nice and Lisbon, ratification could take place without a referendum.

8. Oppermann (2018: 247) mentions as key example the UK government's commitments in 1975 on EC Membership, in 1996 and 1997 on joining the single currency, in 2004 on the Constitutional Treaty, in 2010 on the 'referendum lock' by the European Union Act and in 2013 on EU membership (leading to the 2016 Brexit vote).

9. So far parliaments never voluntarily opted for an EU-related referendum in order to amend the constitution.

10. Membership referendums in five other CEECs were constitutionally required: Estonia, Hungary, Latvia, Romania and Croatia.

11. The question read "Do you agree with the continued participation of Portugal at the construction of the European Union in the context of the Amsterdam Treaty?" The clause enabling a referendum included 'issues of relevant national interest which might be subject of an international agreement'.

12. Whereas 16 countries give parliaments the opportunity to call votes on constitutional amendments, 26 countries can do so on issues of national importance. In 22 instances these issues of national importance may also include treaty ratification, a transfer of powers to or joining international organisations. Popular initiatives can be enforced in eight countries on constitutional amendments, in 18 countries on issues on national importance and in 10 countries on treaty ratification. 


\section{When do governments win EU-related referendums?}

In the EU's institutional machinery the national government is a central actor in the negotiation and decision-making process. As one of the key stakeholders in a successful outcome, governments want to win EU-related referendums. The ratio of successful referendums demonstrates that governments are quite able to do so: less than a quarter of all EU-related referendums ended in defeats. Despite the dominant role governments play in the course of the European integration process, despite all their political power, communicative and financial means, governments do not always convince the necessary majority of voters in referendums. What causes that governments win, but also sometimes lose such referendums? This has not been studied yet as only a couple of authors have researched the government's victory or defeat of these referendums (Hobolt and Riseborough 2005, Wagschal 2007, Closa 2013). Consequently, this chapter will address when governments win EU-related referendums. It looks for the combinations of conditions contributing to government victory, and also addresses the configurations contributing to government defeat (cf. Mello 2014: 1). Since this puzzle is based on all 61 identified cases between 1972 and 2016, it is too small to be solved by statistical tests. The number of cases is too limited to work with a model with multiple variables. Therefore, it is worthwhile to look for an alternative approach which also takes into account combinations of factors. This justifies the application of a method such as qualitative comparative analysis. The next sections will explore potential conditions for government victory and outline the explanatory model. Then the research design and methods are exposed, after which the results are presented.

\subsection{What may contribute to government victory?}

Factors contributing to the successful outcome can be found in studies focussing on the individual level of referendum-voting behaviour (explaining yes-votes), and at the aggregate state level of referendums (explaining successful outcomes). Previous research suggests that the popularity of the government and the state of the economy are important factors that impact on the referendum outcome (Ovortrup 2018b). One approach suggests that the referendum is an expression of issue voting and underlying EU attitudes. A second approach argues that elite cues drive the referendum vote, while a third perspective argues that the vote is driven is based on 'second-order' considerations such as government satisfaction and the evaluation of the economy. These approaches may give an indication of important factors influencing victory or defeat of the government. As De Vreese and Semetko noted, in studies of national referendums on European issues, special emphasis has been put on government approval and issue-related opinions (De Vreese and Semetko 2004: 18). For this study it only makes sense to analyse factors affecting individual voting behaviour inasmuch these same factors also play a substantial role at the aggregate level. For instance, where at the individual level unemployment could affect this individual's vote, at the aggregate level unemployment 
may just have a substantial effect if the number of unemployed has been rising dramatically at the time of the referendum. The next paragraphs will address the potential impact of issue voting and EU attitudes, elite cues, referendum strategies, economic factors, and the types of EU-related referendums.

\subsubsection{Issue voting and EU attitudes}

A first factor concerning issue voting is whether a rather positive attitude towards the EU leads to a pro-European referendum outcome (which is mostly in line with the government's point of view). It is argued that the more positive this attitude in a country is, the larger the number of Yes votes favouring the EU integration issue will be (Wagschal 2007: 61). However, this conventional view of the mechanism of anti- versus pro-European attitudes is disputed, because these attitudes also become intertwined with traditional domestic concerns towards the policy and they are mediated by the intensity of the campaign (Hobolt and Brouard 2011: 319). The impact of individual EU attitudes was stronger among those exposed to campaigns, and the greatest in referendums with the most intense campaigns (Hobolt 2005: 90-1). This implies that the impact of EU attitudes on the individual referendum is dependent on the voter's preferences and exposure and intensity of the campaign. This individual level approach makes it difficult to take EU attitudes as explanatory factor at the aggregate level.

\subsubsection{Elite consensus}

Votersevaluatein severalways what political elitesaredoing.Onewayisthat voters relyoncuesof politicians, partisan positions and campaigns of the political elites they elected. Elite consensus is considered an important factor, measured as parliamentary support for the issue at stake. Even if triggered by a popular initiative to challenge the elite, voters may still rely on party positions. Vospernik found a correlation of 83.6 percent between the result that was expected based on party recommendations and the actual outcome. 83.2 percent of all referendums with elite consensus had the main governing party on the winning side (Vospernik 2018a: 438-9). Distinctive is the size of coalitions either in favour or against the issue. The likelihood of governmental defeat is lower if there is elite consensus on the issue, based on parties' ideological preferences. Thus, the government is more likely to win if it is backed by the main opposition party. Citizens follow elite's recommendations the more uniform these elites present themselves to the voters (Kriesi 2006). In referendums with (a large degree of) elite unanimity, the proposal was backed by a majority of voters in more than 80 percent of the cases. This was illustrated by the high levels of elite consensus on EU accession in Central and Eastern European Countries, reflected in high popular support on the issue. In contrast, the more political parties were polarised on the issue, the lower the support rate was (Wagschal 2007: 66). Support for the 'No' side is stronger if a party with coalition potential advocates a vote against more integration (Qvortrup 2018b). The degree of consensus in parliament and 
government hence tells something on the saliency on the issue among the electorate. The impact of elite consensus might even be stronger when elections took place shortly before the referendum, because the voter's sympathy with a party is relatively recent which gives less space for space for voter volatility.

\subsubsection{Evaluating the government: incumbent support and recent elections}

Based on the literature, also the support for the government in parliament and the timing of the referendum vis-à-vis the electoral cycle are expected to have an impact on the government's chances to win the referendum. Keeping these findings in mind, it is argued below why a governmental majority and government tenure would be relevant factors to include in this analysis on EU-related referendums.

Several studies revealed that unified governments with ample parliamentary backing stand a better chance to win the referendum than governments with a small power base in parliament. A higher number of governing parties (representing larger, diverging parts of the electorate) and a stable government are expected to contribute to a higher level of support (Wagschal 2007: 58-63). The majority government can win if it is able to re-establish the majority by which it was elected. The larger the size of the unified governmental majority, the more likely it is that voters will follow this cue. Therefore, minority governments might face more problems gathering a popular majority of votes. However, if the government's MPs are strongly divided and expressly voicing dissenting opinions, the incumbent's view cannot serve as a reliable cue anymore. In this respect, Vospernik tested some features of the political system on a selection of more than 200 cases from $21 \mathrm{EU}$ member states which held more than two nationwide referendums from 1990 to 2016 (hence including non-EU related referendums). If the government is split on the issue, in 77 percent of the cases the government ends up at the losing side (Vospernik 2018a: 439). Hence, the government parties themselves are eventually crucial in securing a majority for the Yes camp. They may experience pressure to behave 'responsibly' and are bound to endorse the proposed issue, because the negotiations have been concluded with their government's approval. In contrast, the opposition parties cannot be counted upon, because they may be tempted to use EU referendums as a means to mobilise against the incumbent government. As a consequence significant parts of the opposition voters are bound to go to the No camp. Hence, when the governing parties are divided the government cannot (automatically) rely on support from the opposition (Crum 2007: 66 ff.).

Another factor concerns the time that the government has been in office. In general, the government enjoys higher support immediately after a general election (Hobolt and Riseborough 2005: 245). Governments tend to become less popular the longer they are in office and the worse the economic situation is evolving. On the one hand, new governments are more likely to win a referendum on an EU matter because they often enjoy a 'honeymoon period'. On the other hand, the longer the government is in office (in days), the more likely it is 
to lose an EU referendum (Ovortrup 2018b, Szczerbiak and Taggart 2004, Wagschal 2007: 65, Ovortrup 2016: 65). Governments have to behave 'consensually' to minimise the risk of defeat (Vospernik 2018b: 135). This fits into Franklin's concept of treating the referendum as secondorder elections, particularly if first-order elections took place a long time before. "While a popular government might expect to see its referendum proposals approved, an unpopular government will often see its proposals turned down" (Franklin et al. 1995: 106). This links the performance of the government to the evaluation of the EU policy proposal that the government has negotiated and of which it claims that it is an improvement over the status quo. Ill-informed voters will assess a negotiated treaty to some extent based on the domestic achievements of the government and the opposition (Schneider 2018: 419). The longer the period between the referendum and the last elections, the more likely a failed outcome is. Hence it is worthwhile to look whether governments win referendums when governments are still enjoying their honeymoon period. ${ }^{3}$

\subsubsection{Offensive referendum strategies}

Referendums are difficult for any government, particularly due to the unpredictability of their results. Therefore, governments might be expected to stay away from such an uncontrollable device (Closa 2007). If referendums are organized by governments they are only staged when the prospects of a successful outcome are in line with the government's wishes (Sciarini 2017: 79). Based on the prospect theory that decision-making under risk is most fundamentally driven by prospects of changes in utility, it is argued that decision-makers view their choices in terms of either avoiding losses or realising gains. Oppermann framed this choice as one between two strategic modes of governance: offensive when governments pledge EU referendums in order to realize potential political gains, aimed at promoting certain policy outcomes (improving the status quo), and defensive when they pledge EU referendums in order to avoid potential political losses with respect to their electoral prospects or their policy preferences on European integration (maintaining the status quo) (Oppermann 2013b: 6889). The decision to hold a referendum hints to some strategic calculations. Although in both modes governments may pledge referendums, their main strategic interests are different (policy promoting vs. position maintaining). Building on Bjørklund (1982) and Morel $^{4}$ (2001), Mendez et al. (2014) distinguish three overriding logics for pledging referendums: because they are constitutionally mandatory ${ }^{5}$, because of partisan calculus, or due to reasons of appropriateness ${ }^{6}$.

Facing these motives, when do governments follow an either offensive or defensive strategy? If the strategic mode of government is offensive in order to promote a policy outcome in line with the government's wishes, one would expect that this indeed contributes to a successful outcome. The government's main interest is to actively win the referendum. It could do so for policy-seeking reasons by bypassing a parliamentary majority or by reinforcing its own position at either the national or EU level (Oppermann 2012: 219). Governments hold offensive EU referendums to bolster their domestic support when the 
EU is popular and the next national elections are far away. This offensive mode also applies when the government is forced to hold the referendum for reasons of constitutionality. A referendum could be mandatory if the government wants to realize its desired policy outcome for of treaty ratification and is willing to take the referendum risk.

Alternatively, the strategic mode of governments is defensive when its overriding aim is not to win the referendum, but to maintain its position and other actors take the lead. First, governments call the referendum for mediating reasons to overcome internal party or coalition divisions, or aim to depoliticise the controversial issue from upcoming elections (Finke and König 2009: 351, 358-9). When the EU is unpopular and elections are close, governments pledge defensive referendums just before the election to avoid being punished by voters for pursuing an unpopular EU policy (Prosser 2016). If governments use the referendum as depoliticising tool, the "referendum may not produce a victory but it will provide a government with an excuse for failure" (Tierney 2012: 125). In that case, the government is not seeking a victory, but merely its own way out from a cornered position. Second, when confronted by a popular or parliamentary initiative triggering a referendum, the government defends its position in order to avoid political losses.

A third defensive strategy applies when governments have de facto no choice of holding the referendum given the endogenous domestic political pressure or exogenous domino trigger effects (Closa 2007:1315-25). The sequencing of referendums was hoped to work out in in such a way that a favourable result in the first country could affect the result in other countries. During both enlargement rounds in the Nordic countries in the 1970s and 199os, the referendum in Norway was scheduled last, according to this domino strategy hoping that the preceding successful accession referendums in Austria, Finland and Sweden would spillover to the Norwegian voters. A similar idea was considered when the last three accession referendums in 2003 were held in the Czech Republic, Estonia, and Latvia, whose populations were perceived as the most Eurosceptic (Tierney 2012: 113). Although the Norwegians decided otherwise in 1972 and 1994, the question remains whether spillover effects had a significant impact on the outcome. Szczerbiak and Taggart found only marginal domino-effects in the series of accession referendums in Central and Eastern European countries (Szczerbiak and Taggart 2004: 571). Hence, domino effects it could only be significant if the timing of the referendum is such that voters would be highly influenced in the same direction by the outcome, public opinion and consequences of the preceding vote(s) in other countries. Therefore the offensive or defensive position the government finds itself in when the referendum is triggered may well have an impact on its (at least starting) position to win the referendum.

\subsubsection{Economic circumstances and net redistribution gains}

Two questions can be addressed from the economic perspective: how is the country developing in economic terms at the time of the referendum, and is society expected to gain economically 
from the issue at stake? Economic circumstances and expectations are considered relevant explanatory variables for supporting EU integration issues (Hobolt and Riseborough 2005: 246). This builds upon the literature on economic voting theory (Lewis-Beck and Paldam 2000), treating referendums as second-order elections, by which voters do not just vote on the issue at stake but link their vote to other issues like the state of the economy (such as real GDP growth, unemployment, inflation rates or exports). First, the government's performance is often linked to recent national economic developments, both in the news coverage and in the campaigns. News on the state of the economy is not only dominated by its current figures, but also compared to the previous year in order to mark short term trends. Therefore, it is expected that governments succeed in times of economic prosperity. However, even in times of economic growth voters may signal their distrust in the government if unemployment is sky high. Vice versa, a period of decreasing unemployment fused with a deteriorating economic situation might motivate voters to take every opportunity to call for a dramatic change of the government's policy. In this way, economic factors drive concerns about Europe. 'In good times, citizens evaluate integration proposals against the backdrop of strong economic growth and low unemployment' (Sattler and Urpelainen 2012: 1110). Therefore, both economic growth and unemployment figures should be observed when assessing whether the overall economic situation is improving or deteriorating.

A second factor is the redistribution effect of European integration, also known as the 'rent-seeking-thesis'. This concept of redistribution gains has not yet been taken into account in the referendum literature (consequently it is not addressed in Chapter 2). According to this utilitarian theory, individual support for the EU is based on a cost-benefit calculation. Voters generally weigh both their individual as well as their country's position in determining their attitude towards the EU. Redistributive concerns are crucial determinants for individual EU attitudes (cf. Eichenberg and Dalton 2007: 133). Qvortrup expected that voters endorsed an EU policy if it has brought about aggregate perceived benefits (Ovortrup 2018b). If increased integration hurts the economy in the short-run, this would affect the government's chances to win. In countries where, according to voters' perceptions, relatively high welfare losses are expected because of the consequences of the referendum issue, the government is likely to lose referendums favouring more integration (Wagschal 2007: 56). Alternatively, countries which are expecting welfare gains by the EU's redistribution policy, voters might prefer to support the government's stance. Hence, increased economic prosperity causes the electorate to endorse the government. For instance in times of economic crisis, citizens may view European integration as a source of solution for their economic situation, for instance due to positive net transfers from the EU to their country. This is mostly applicable in the contrast between prospective net recipients and net contributors to the EU budget when (non) membership would change the status quo. Based on this rent-seeking thesis, one might expect that countries which are prospective net recipients of the EU are more eager to support referendums favouring integration than countries which are prospective net contributors.

After having discussed several potential factors that may lead to government victory, six conditions are to be operationalized in the analysis: 1) unified majority support 
for the government itself, 2) elite consensus on the issue, 3) whether recent elections took place 4) whether an offensive or defensive referendum strategy was followed, 5) whether the state experienced rising economic growth and employment, and 6) whether the state would become an EU net recipient or net contributor.

\subsubsection{Types of EU referendums}

Could the type of EU referendum make a difference in the impact of conditions on the referendum outcome? Not all EU referendums are one of the same kind after all. The fundamental question of membership has a different nature compared to the question of ratifying a comprehensive (reform) treaty or a specific policy issue. Whereas the membership issue concerns joining or leaving the EU and the stakes are very high, EU treaty ratification or policy issues deal with less fundamental subjects. As outlined in Chapter 2, the issues on referendums related to the EU are commonly classified in a threefold typology: on (1) EU/EEA membership; (2) on the ratification of a comprehensive EC/EU treaty; or (3) on specific policy issues which do not relate to membership or full-scale revision of treaties (Mendez et al. 2014, Oppermann 2012: 215-16). These different referendum issues may take into account different voters' considerations and could put some of the conditions under which the referendums take place in a different context. Hence, separate analyses of the sets of membership, treaty and policy referendums takes these different contexts into account, whereas a single analysis could reveal different patterns in which a successful outcome is attained. In this way, the classification by type would function as a contextual mediating factor.

\subsubsection{Combinations of factors}

The six selected conditions might each have a direct impact on the referendum outcome. However, the question remains what theoretical expectations can be drawn on the effects of the combination of certain conditions across the three types of EU-related referendums. Several combinations of conditions might work differently mediated by different contextual types of referendums, because of the different nature of the questions at stake. Figure 4.1 displays the (two configurations of) conditions that are expected to contribute to government victory and how this is specified by the type of referendum. Based on the discussed theoretical concepts above, two theoretical propositions are formulated about particular combinations of conditions, producing an additive effect (cf. Cacciatore et al. 2015: 1188-9):

1. Relying on political stability. A large degree of elite consensus in conjunction with a unified majority government support will almost certainly lead to the government's victory. Not because these conditions only contribute to success in combination, but because their combination gives a stronger effect: stable political consensus. The majority government is backed by a large elite, while at the same time the elite consensus is not distorted by diverging views from the government. However, when both factors are missing, it 
becomes difficult to triumph.

2. Utilising economic prosperity. It is expected that economic prosperity places the incumbent government in such a favourable position that if it follows an offensive strategy, it easily wins the referendum, irrespective of the parliamentary support for the government, the issue at stake or the electoral cycle. This proposition also could play across all three referendum types. If the government is in a defensive position, however, the positive economic circumstances are not expected to suffice for winning the vote.

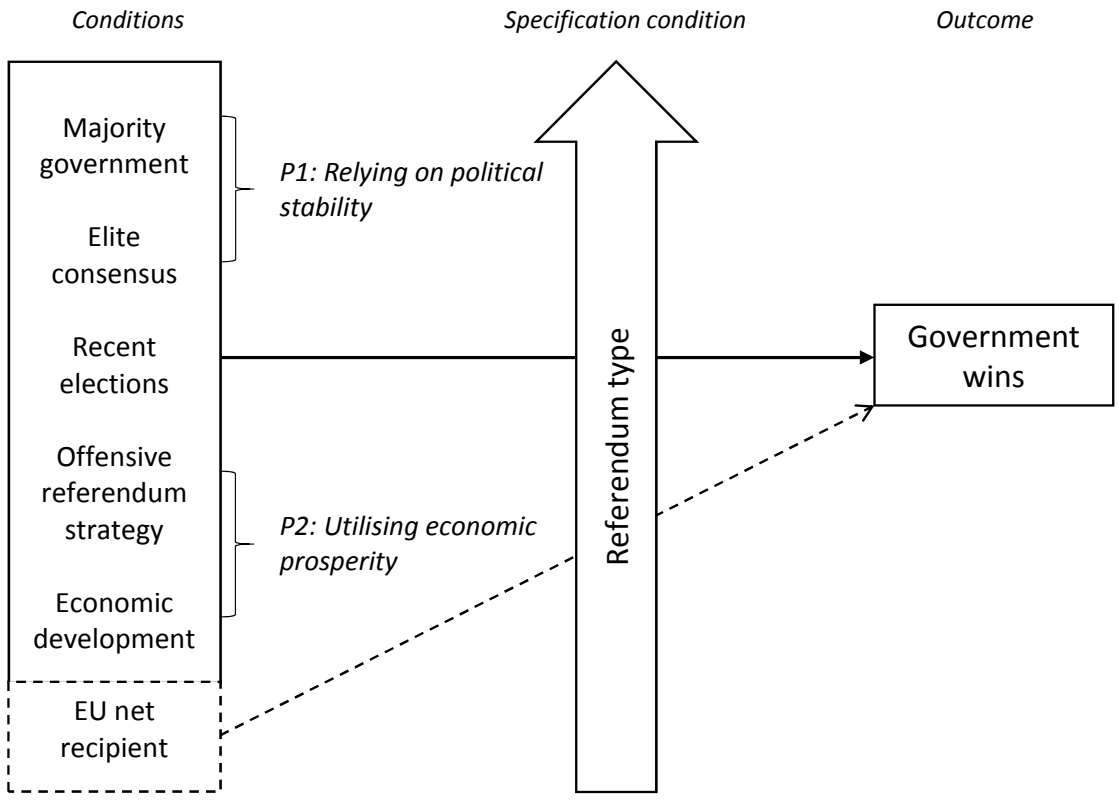

Figure 4.1. Conditions and propositions contributing to government victory.

...... . - Only included in the analysis of Membership referendums.

\subsection{Data and methods}

A dataset including information on all 61 EU-related referendums between 1972 and 2016 is used in order to assess the impact of the aforementioned conditions on the outcome. ${ }^{19}$ So far 27 referendums on membership took place; 16 referendums on treaty ratification; and 18 referendums on policy issues. The treaty referendums include the three cases of 'double' referendums in Denmark on the Maastricht Treaty, and in Ireland on the Nice and Lisbon Treaties. Although these cases are the consequence of the previous, failed, referendum, it is assumed that the causal mechanisms work out similarly for these three cases. 


\subsubsection{Operationalisation}

How each condition is measured as metric variable is displayed in Table 4.1. For all six conditions a four-point scale is used $(0,0.33,0.67$ and 1$) .{ }^{20}$ The reason for using these metric scales is that they allow to include qualitative elements in assigning the values, selected by the researcher. Fuzzy-sets comprise both qualitative and quantitative states. The qualitative feature forms the breaking points of being in or out of the set (o or 1), while the degree of membership (between o and 1), provides the quantitative aspect (Vis 2009: 38-9). For instance, in order to measure elite consensus, it is argued that if less than 3/4 of the MPs in the lower house support the issue, there is no consensus. So the assigned quantitative score is $<0.5$. However, if more than 3/4 or even more than 5/6 of the MPs support it, one can argue that there is a considerable degree of elite consensus. The assigned score is then $>0.5$. The tables in the Appendix provide an overview of all relevant data. ${ }^{21}$

Table 4.1. Measurement and calibration of conditions.

\begin{tabular}{|c|c|c|c|c|}
\hline \multirow[t]{2}{*}{ Condition } & \multicolumn{3}{|l|}{ Fully out } & \multirow{2}{*}{$\begin{array}{l}\text { Fully in } \\
1.0\end{array}$} \\
\hline & 0.0 & 0.33 & 0.67 & \\
\hline $\begin{array}{l}\text { Majority } \\
\text { government }\end{array}$ & $\begin{array}{l}\text { Minority } \\
\text { government } \\
\text { support <0.45 }\end{array}$ & $\begin{array}{l}\text { Minority } \\
\text { government }>0.45\end{array}$ & $\begin{array}{l}\text { Majority MPs } \\
\text { support <2/3 }\end{array}$ & $\begin{array}{l}>=2 / 3 \text { unified } \\
\text { MPs support }\end{array}$ \\
\hline Elite consensus & $\begin{array}{l}\text { Minority MPs } \\
\text { support }\end{array}$ & $\begin{array}{l}\text { Majority MPs sup- } \\
\text { port <3/4 }\end{array}$ & $>3 / 4$ MPs support & $\begin{array}{l}>=5 / 6 \mathrm{MPs} \\
\text { support }\end{array}$ \\
\hline $\begin{array}{l}\text { Recent elections: } \\
\text { government days in } \\
\text { office }\end{array}$ & $>650$ days & $>365<650$ days & $>250<365$ days & $<250$ days $^{22}$ \\
\hline $\begin{array}{l}\text { Offensive } \\
\text { referendum strategy }\end{array}$ & - & $\begin{array}{l}\text { Government calls } \\
\text { referendum to } \\
\text { mediate / is legally } \\
\text { obliged to hold } \\
\text { a referendum } \\
\text { (parliamentary or } \\
\text { popular initiative) }\end{array}$ & $\begin{array}{l}\text { Government } \\
\text { pushes for } \\
\text { constitutionally } \\
\text { mandatory } \\
\text { referendum } \\
\text { / circumvent } \\
\text { majority MPs }\end{array}$ & $\begin{array}{l}\text { Government } \\
\text { aims to } \\
\text { reinforce its } \\
\text { position }\end{array}$ \\
\hline $\begin{array}{l}\text { Economic develop- } \\
\text { ment (GDP and U: (t } \\
<>t-1)) \text { compared to } \\
\text { the previous year }\end{array}$ & $\begin{array}{l}\text { Economic } \\
\text { stagnation } \\
\text { and increasing } \\
\text { unemployment }\end{array}$ & $\begin{array}{l}\text { Decreasing } \\
\text { economic growth } \\
\text { and increasing } \\
\text { unemployment }\end{array}$ & $\begin{array}{l}\text { Limited economic } \\
\text { and employment } \\
\text { growth }\end{array}$ & $\begin{array}{l}\text { Strong } \\
\text { economic and } \\
\text { employment } \\
\text { growth }\end{array}$ \\
\hline EU net recipient & $\begin{array}{l}\text { Small net } \\
\text { contributor }\end{array}$ & $\begin{array}{l}\text { Marginal net } \\
\text { contributor }\end{array}$ & $\begin{array}{l}\text { Marginal net } \\
\text { recipient }\end{array}$ & $\begin{array}{l}\text { Large net } \\
\text { recipient }\end{array}$ \\
\hline
\end{tabular}

Of all 61 referendums, 46 cases resulted in government victory, while in 15 cases the government lost. A successful outcome is defined as a valid victory for the government: i.e. a minimum required majority voting in line with the government's position in order to attain its policy objective (ranging from 50.1 to 100 percent support in case of a simple popular majority of the votes cast). A metric scale of six categories measures the degree of success: from 1 (full victory) to o (full defeat); and in between $0.83,0.67$-rather in; 0.33 and 0.16 -rather out. The competitive nature of the referendum campaigns often means that many ballots are decided by narrow margins (Rose 2018: 4). A referendum result of 52 percent support means a 
government victory but is not the same landslide victory of go percent support. So the larger the degree of popular support, the larger the degree of government victory.

The conditions Offensive referendum strategy (OFF), Economic development (ECD), and EU net recipient $(\mathrm{REC})$ require some elucidation. Offensive referendum strategies are coded 0.67 when governments push for a constitutionally required referendum or when they want to circumvent opposing parliamentary majorities. In both cases, the governments are conscious of the necessity of the referendum in order to achieve their policy objective, but this makes it a less offensive strategy. When governments call the referendum for mediating reasons it scores 0.33 . This defensive argument is applicable when governments do not want a referendum but have de facto no alternative but holding it, e.g. in order to overcome intraparty rifts, or when they are legally facing a popular or parliamentary initiative triggering a referendum. On what overriding strategy the government's strategy was driven depends on substantial case knowledge, such as partly classified by Mendez et al. (2017: 28-31).

Economic development is considered fully present in case of a substantially increasing economic growth (in terms of real GDP) and decreasing unemployment compared to the year preceding the referendum. In case of only marginal growth, the cases are coded 0.67 , while in case of decreasing growth and increasing unemployment the cases' membership score falls below the 0.5 threshold. Being interested in the logic of both economic combinations, and not the effect of either one of them, the economic growth and unemployment figures are merged into one macro-economic condition ex ante, labelled as economic development. For the presence of Economic development the average calibrated value of economic growth and decreasing unemployment has to be $>0.5$ in order to be considered 'present'.

Concerning the status of being an EU net recipient, annually the net receipt or net contribution diverges from 0.1 to several billion Euros per member state. The country is considered a prospective EU net recipient (1.0) or net contributor (0.0) when the operating budgetary balance of net contributions and net revenues displays a clear difference in favour to the recipient member state, related to its GDP (European Commission 2015).

\subsubsection{Bivariate analysis}

The relative strength of each condition can be measured related to the outcome. A bivariate analysis of government success is presented in Table 4.2. In order to make a clear and contrasting distinction between the presence or absence of the condition and the outcome, the conditions and the outcome are coded in a dichotomised way. If a metric scale were to be used for the conditions and the outcome, the fuzzy score of each case would blur this distinction. 
Table 4.2. Bivariate analysis of government victory. Epsilon difference of proportions related to the success and failure of the government.

\begin{tabular}{|c|c|c|c|c|}
\hline MAJ & Majority government & Minority government & Total & $\begin{array}{l}\text { Strength } \\
\text { (Epsilon) }\end{array}$ \\
\hline $\begin{array}{l}\text { Membership success } \\
\text { Membership failure }\end{array}$ & $\begin{array}{l}20(95 \%) \\
1(5 \%)\end{array}$ & $\begin{array}{l}3(50 \%) \\
3(50 \%)\end{array}$ & $\begin{array}{l}23 \\
4\end{array}$ & 0.45 \\
\hline $\begin{array}{l}\text { Treaty success } \\
\text { Treaty failure }\end{array}$ & $\begin{array}{l}4(57 \%) \\
3(43 \%) \\
\end{array}$ & $\begin{array}{l}7(78 \%) \\
2(22 \%) \\
\end{array}$ & $\begin{array}{l}11 \\
5\end{array}$ & -0.21 \\
\hline $\begin{array}{l}\text { Policy success } \\
\text { Policy failure }\end{array}$ & $\begin{array}{l}11(79 \%) \\
3(21 \%)\end{array}$ & $\begin{array}{l}1(25 \%) \\
3(75 \%)\end{array}$ & $\begin{array}{l}12 \\
6\end{array}$ & 0.54 \\
\hline $\begin{array}{l}\text { Total success } \\
\text { Total failure }\end{array}$ & $\begin{array}{l}35(83 \%) \\
7(17 \%) \\
\end{array}$ & $\begin{array}{l}11(58 \%) \\
8(42 \%)\end{array}$ & $\begin{array}{l}46 \\
15\end{array}$ & 0.25 \\
\hline ELI & Elite consensus & Elite polarisation & Total & $\begin{array}{l}\text { Strength } \\
\text { (Epsilon) }\end{array}$ \\
\hline $\begin{array}{l}\text { Membership success } \\
\text { Membership failure }\end{array}$ & $\begin{array}{l}15(100 \%) \\
0(0 \%)\end{array}$ & $\begin{array}{l}8(67 \%) \\
4(33 \%\end{array}$ & $\begin{array}{l}23 \\
4\end{array}$ & 0.33 \\
\hline $\begin{array}{l}\text { Treaty success } \\
\text { Treaty failure }\end{array}$ & $\begin{array}{l}10(71 \%) \\
4(29 \%) \\
\end{array}$ & $\begin{array}{l}1(50 \%) \\
1(50 \%\end{array}$ & $\begin{array}{l}11 \\
5\end{array}$ & 0.21 \\
\hline $\begin{array}{l}\text { Policy success } \\
\text { Policy failure }\end{array}$ & $\begin{array}{l}7(70 \%) \\
3(30 \%)\end{array}$ & $\begin{array}{l}5(63 \%) \\
3(38 \%)\end{array}$ & $\begin{array}{l}12 \\
6\end{array}$ & 0.08 \\
\hline $\begin{array}{l}\text { Total success } \\
\text { Total failure }\end{array}$ & $\begin{array}{l}32(82 \%) \\
7(18 \%)\end{array}$ & $\begin{array}{l}14(64 \%) \\
8(36 \%)\end{array}$ & $\begin{array}{l}46 \\
15\end{array}$ & 0.18 \\
\hline ELE & Recent elections & No recent elections & Total & $\begin{array}{l}\text { Strength } \\
\text { (Epsilon) }\end{array}$ \\
\hline $\begin{array}{l}\text { Membership success } \\
\text { Membership failure }\end{array}$ & $\begin{array}{l}10(100 \%) \\
\circ(0 \%)\end{array}$ & $\begin{array}{l}13(76 \%) \\
4(24 \%)\end{array}$ & $\begin{array}{l}23 \\
4\end{array}$ & 0.24 \\
\hline $\begin{array}{l}\text { Treaty success } \\
\text { Treaty failure }\end{array}$ & $\begin{array}{l}6(100 \%) \\
0(0 \%)\end{array}$ & $\begin{array}{l}5(50 \%) \\
5(50 \%)\end{array}$ & $\begin{array}{l}11 \\
5\end{array}$ & 0.50 \\
\hline $\begin{array}{l}\text { Policy success } \\
\text { Policy failure }\end{array}$ & $\begin{array}{l}4(67 \%) \\
2(33 \%) \\
\end{array}$ & $\begin{array}{l}8(67 \%) \\
4(33 \%)\end{array}$ & $\begin{array}{l}12 \\
6 \\
\end{array}$ & 0.00 \\
\hline $\begin{array}{l}\text { Total success } \\
\text { Total failure }\end{array}$ & $\begin{array}{l}20(91 \%) \\
2(9 \%)\end{array}$ & $\begin{array}{l}26(63 \%) \\
13(37 \%)\end{array}$ & $\begin{array}{l}46 \\
15\end{array}$ & 0.28 \\
\hline OFF & Offensive strategy & Defensive strategy & Total & $\begin{array}{l}\text { Strength } \\
\text { (Epsilon) }\end{array}$ \\
\hline $\begin{array}{l}\text { Membership success } \\
\text { Membership failure }\end{array}$ & $\begin{array}{l}15(94 \%) \\
1(6 \%) \\
\end{array}$ & $\begin{array}{l}8(73 \%) \\
3(27 \%)\end{array}$ & $\begin{array}{l}23 \\
4\end{array}$ & 0.21 \\
\hline $\begin{array}{l}\text { Treaty success } \\
\text { Treaty failure }\end{array}$ & $\begin{array}{l}10(71 \%) \\
4(29 \%)\end{array}$ & $\begin{array}{l}1(50 \%) \\
1(50 \%)\end{array}$ & $\begin{array}{l}11 \\
5\end{array}$ & 0.21 \\
\hline Policy success & $6(75 \%)$ & $6(60 \%)$ & 12 & 0.15 \\
\hline Policy failure & $2(25 \%)$ & $4(40 \%)$ & 6 & \\
\hline $\begin{array}{l}\text { Total success } \\
\text { Total failure }\end{array}$ & $\begin{array}{l}31(82 \%) \\
7(18 \%\end{array}$ & $\begin{array}{l}15(65 \%) \\
8(35 \%)\end{array}$ & $\begin{array}{l}46 \\
15\end{array}$ & 0.16 \\
\hline
\end{tabular}




\begin{tabular}{|c|c|c|c|c|}
\hline ECD & Economic prosperity & Economic decline & Total & $\begin{array}{l}\text { Strength } \\
\text { (Epsilon) }\end{array}$ \\
\hline $\begin{array}{l}\text { Membership success } \\
\text { Membership failure }\end{array}$ & $\begin{array}{l}17(89 \%) \\
2(11 \%)\end{array}$ & $\begin{array}{l}6(75 \%) \\
2(25 \%)\end{array}$ & $\begin{array}{l}23 \\
4\end{array}$ & 0.14 \\
\hline $\begin{array}{l}\text { Treaty success } \\
\text { Treaty failure }\end{array}$ & $\begin{array}{l}8(100 \%) \\
\circ(0 \%)\end{array}$ & $\begin{array}{l}3(37 \%) \\
5(63 \%)\end{array}$ & $\begin{array}{l}11 \\
5\end{array}$ & 0.63 \\
\hline $\begin{array}{l}\text { Policy success } \\
\text { Policy failure }\end{array}$ & $\begin{array}{l}6(60 \%) \\
4(40 \%)\end{array}$ & $\begin{array}{l}6(75 \%) \\
2(25 \%)\end{array}$ & $\begin{array}{l}12 \\
6\end{array}$ & -0.15 \\
\hline $\begin{array}{l}\text { Total success } \\
\text { Total failure }\end{array}$ & $\begin{array}{l}31(84 \%) \\
6(16 \%) \\
\end{array}$ & $\begin{array}{l}15(63 \%) \\
9(37 \%)\end{array}$ & $\begin{array}{l}46 \\
15 \\
\end{array}$ & 0.21 \\
\hline REC & Net recipient & No net recipient & Total & $\begin{array}{l}\text { Strength } \\
\text { (Epsilon) }\end{array}$ \\
\hline $\begin{array}{l}\text { Membership success } \\
\text { Membership failure }\end{array}$ & $\begin{array}{l}15(100 \%) \\
0(0 \%)\end{array}$ & $\begin{array}{l}8(67 \%) \\
4(33 \%)\end{array}$ & $\begin{array}{l}23 \\
4\end{array}$ & 0.33 \\
\hline $\begin{array}{l}\text { Treaty success } \\
\text { Treaty failure }\end{array}$ & $\begin{array}{l}8(73 \%) \\
3(27 \%)\end{array}$ & $\begin{array}{l}3(60 \%) \\
2(40 \%)\end{array}$ & $\begin{array}{l}11 \\
5\end{array}$ & 0.13 \\
\hline $\begin{array}{l}\text { Policy success } \\
\text { Policy failure }\end{array}$ & $\begin{array}{l}3(60 \%) \\
2(40 \%)\end{array}$ & $\begin{array}{l}9(69 \%) \\
4(31 \%)\end{array}$ & $\begin{array}{l}12 \\
6\end{array}$ & -0.09 \\
\hline $\begin{array}{l}\text { Total success } \\
\text { Total failure }\end{array}$ & $\begin{array}{l}26(84 \%) \\
5(16 \%)\end{array}$ & $\begin{array}{l}20(67 \%) \\
10(33 \%)\end{array}$ & $\begin{array}{l}46 \\
15\end{array}$ & 0.17 \\
\hline
\end{tabular}

Table 4.2 shows for instance that of the 21 membership referendums with a majority government (condition 'MAJ') 20 (95\%) resulted in a government victory, while of the 6 minority government cases only $3(50 \%)$ resulted in a government victory. The Epsilon of 0.45 is the difference of proportions related to the outcome (0.95) and the non-outcome (0.50). This suggests that having a majority government has a relatively strong relationship (0.45) with won membership referendums. The relationship of majority governments with won policy referendums is even higher (0.54). However, the relationship between majority governments with treaty referendums seems to reflect the opposite (-0.21). The Epsilon score of the condition majority government across the three types and the outcome lies in between (0.25). To highlight some other examples, recent elections and economic development are relatively strongly related to government victory among treaty referendums (0.50 and o.63). Offensive referendum strategies seem to be related equally strong across the referendum types (between 0.15 and o.21). Economic development even seems to relate negatively across policy referendums (-o.15), while elite consensus and becoming an EU net recipient relate the strongest among membership referendums (0.33).

The general effect that can be observed in this table is that the type of referendum matters to the strength of the relationship between each condition and the outcome. Combining all cases in a single analysis would not only confuse the quantitative strength of the explanatory model, but also distort the theoretical qualitative considerations that not all EU-related referendums work in the same way. Table 4.2 also demonstrates a strong correlation for the condition prospective EU 'net recipient' among successful membership referendums (0.33) while it displays only limited relevance for treaty referendums (0.13) and 
even a small opposite relationship for policy referendums (-o.og). The latter would imply that not being (or not becoming) a net recipient is associated to government victory. Being interested in conditions contributing to government victory, it would only make sense to consider the condition prospective EU net recipient if the outcome of the referendum could change this status of prospective net recipient or net contributor. Therefore, this factor will only be included in the analysis of Membership referendums.

\subsubsection{Method: fuzzy-set Qualitative Comparative Analysis}

The method of fuzzy-set Qualitative Comparative Analysis (fsQCA) is applied in order to identify which of these conditions are individually necessary and which (combinations of) conditions are sufficient configurations for government victory. What are the merits of this method? First, OCA does not only look at isolated conditions, but also models causal complexity. Some conditions contribute to government victory in combination with other factors. This is called conjunctural causation (cf. Hinterleitner et al. 2016). It may well be that only a weak bivariate relationship exists between one condition and the outcome, while in combination this relationship proves to be much stronger. Second, various configurations of conditions can induce the same successful outcome, called equifinal solution terms. Third, OCA is able to cope with an intermediate number of cases of about 50 or less (Stokke 2007: 501). It is therefore designed to analyse a larger number of cases than case studies, without applying statistical regression based on statistical distribution techniques. Fourth, the assessment of necessary and sufficient conditions provides for more fine-tuned results than other comparative methods and allows the exclusion of conditions which are neither necessary nor sufficient causal paths (cf. Vandecasteele et al. 2015: 6). Finally, OCA is not deterministic. It allows for some probabilistic aspects, indicated by two main parameters of fit: consistency and coverage.

Why would a configurational comparative method as OCA be an adequate method for this study? First, because this study is interested in the combinations of causes of a given effect: winning EU-related referendums. The combination of both the interaction of factors (conjunctural causation) and multiple solution paths next to each other (equifinality) makes OCA qualified to interpret complex causal processes (Cacciatore et al. 2015: 1205). Second, fsQCA is useful for the analysis of an intermediate-set of purposely selected cases that allows "for modest generalization (external validity); the use of in-depth case knowledge to ensure internal validity; and an inductive, explorative, and iterative mode of reasoning" (Thomann and Magetti 2017: 3-4). The aim is to establish valid causal inference, i.e. learning about the causes of an effect from the observed data. Which conditions (X) are necessary and sufficient for the government to win the referendum (Y)? For such Y-centred research, it makes sense to search for the configuration of several causal conditions that reveals the causal pathways that lead to the successful outcome of interest (cf. Blatter and Haverland 2012). Intermediate- $N$ studies enable to have intense qualitative engagement with the cases, so in-depth case knowledge, which is essential for measurement and internal validity. The 
results of OCA are interpreted as patterns across cases (cross-case inference), without indepth qualitative treatment of individual cases, however. Third, it is particularly useful as inductive, theory-building approach because no established theories are available. "Theories, explanatory frameworks, concepts, and analytic decisions are refined based on preliminary empirical insights gained throughout the analysis; sampling and measurement decisions are respecified using theoretical or conceptual insights." (Thomann and Magetti 2017: 10).

How is the method applied in this study? fsOCA treats conditions as sets in which cases have membership or not. The attribution of cases to sets is called 'calibration' (Hinterleitner et al. 2016: 556). In assigning the values among all cases the so-called 'qualitative method' of calibration is applied. This technique commissions the researcher to define theoretically the full membership of a case in a fuzzy set (1.0), the full non-membership (0.0) and the point of maximum ambiguity (normally 0.5) (Schneider and Wagemann 2012: 35 ff., 198-211). For or the outcome, this point distinguishes government victory (>0.5) from government defeat (<0.5). A clear distinction has to be made for each case to what category it belongs. The values between 0.0 and 0.5 and 1.0 are categorizations of degrees of membership, based on quantitative data and substantive knowledge of each case. This allows for polytomous coding of conditions instead of dichotomous coding. In this study, a four-value fuzzy set, or six-value fuzzy set is used. This allows the researcher to include more fine-grained qualitative elements in the calibration of the conditions.

Applying the enhanced standard analysis relying on the intermediate solution, theoretically informed directional expectations are made about empirically unobserved configurations.

These directional expectations enable to include these unobserved configurations of the truth table in the analysis, if they are based on tenable assumptions. Hence, the directional expectations are coded positively (1) in case they should contribute the outcome (1), and coded negatively (o), in case they should not, or instead would contribute to the non-outcome. In order to avoid confusing configurations, all six conditions have been formulated positively, i.e. they are theoretically expected to contribute to a successful outcome (1) (Rihoux and De Meur 2009: 39-48).

\subsection{Results}

The OCAs of sufficient conditions start with analysing the truth tables (included in Table A4.4). The analysis then provides the sufficient solution paths, and the sufficiency consistency and coverage of all solution paths, for each of the three types of referendums. Subsequently the results of the analysis of necessity and the analysis of the negated outcome are presented. 


\subsubsection{Sufficient conditions}

23 of 27 membership referendums had a successful outcome for the government. The large success rate is not surprising, as countries quite often apply for membership to an international organisation after an economic crisis or in order to join a club of richer nations. Economic aspiration and the wish to return into the heart of Europe, away from the communist legacy, enabled CEECs to embrace EU membership (Schneider 2018: 423). The intermediate solution term as presented in Table 4.3 shows that cases can be explained by five solution paths, so-called paths of conjunctural causations. The table columns display for each path the consistency, the PRI score (Proportional Reduction in Inconsistency i.e. the relevance of the combination vis-à-vis compared to the negated outcome), the raw coverage (of cases also explained by other paths) and the unique coverage (of cases only explained by this path).

Solution path 1 can be characterised as the 'economic honeymoon' in which the referendum took place in times of economic prosperity with a new government. The second path can be labelled as 'defensive majority governments'. They did not follow an offensive strategy, but were large and unified enough to win it. The third path relies on 'majoritarian governments becoming net recipients'. The fourth path combines countries with broad and stable political consensus in bright economic circumstances, while the fifth path combines offensive governments becoming net recipients in good economic times.

The plots in Figure 4.2 illustrate how the cases score on the intermediate solution terms of the three analyses on membership, treaty and policy referendums. The XY-plot helps to locate cases with regard to their causal role, because it verifies which cases are not explained yet and which cases contradict the findings (Cacciatore et al. 2015: 1205). Cases above the diagonal are consistent. Cases in the upper right quadrant, above the diagonal are typical. Cases in the upper left quadrant are deviant for coverage, while cases in the upper right quadrant, below the diagonal, are deviant for consistency in degree. Cases in the lower right quadrant are deviant for consistency in kind, while cases in the lower left quadrant are irrelevant, i.e. these ought to be failed cases. The plot of membership referendums shows that there are no deviant cases consistency or coverage, as no cases appear in the upper left (deviant case coverage) or bottom right (deviant case consistency) areas. Instead, 19 of 23 government victories are located in the area of typical cases, while the 4 cases are deviant in consistency in degree: they score higher on the condition(s) on the X-axis than on the outcome on the Y-axis. The typical and deviant cases are discussed in more detail in Chapter 5 . 
Table 4.3. Sufficiency analyses for successful referendum outcomes (OUT).

\section{Membership referendums $(n=27)$}

Intermediate solution: $\mathrm{ECD}{ }^{*} \mathrm{ELE}+\mathrm{MAJ}^{*} \mathrm{Off}+\mathrm{MAJ}^{*} \mathrm{REC}+\mathrm{ECD}^{*} \mathrm{ELI}^{*} \mathrm{MAJ}+\mathrm{ECD}^{*} \mathrm{OFF}{ }^{*} \mathrm{REC} \rightarrow \mathrm{OUT}$

\begin{tabular}{|c|c|c|c|c|c|}
\hline & Cons. & PRI & Raw C & Unique cov & Cases covered. Consistency threshold $=0.8$ \\
\hline 1 ECD*ELE & 0.928 & 0.891 & 0.437 & 0.067 & $\begin{array}{l}\text { SWE1994; SMR2013; EST2003; } \\
\text { SLK2003:CZE2003,HUN2003:LAT2O03.LIT2O03 }\end{array}$ \\
\hline $2 \mathrm{MAJ}^{*}$ off & 0.982 & 0.970 & 0.461 & 0.025 & $\begin{array}{l}\text { SWI2O01; GBR1975; SMR2O13; } \\
\text { FIN1994,SWI1997; POL2O03; SLK2O03 }\end{array}$ \\
\hline $3 \mathrm{MAJ}^{*} \mathrm{REC}$ & 1.000 & 1.000 & 0.456 & 0.102 & $\begin{array}{l}\text { GRE1982,MAL2OO3; GBR1975; SLO2OO3; } \\
\text { CRO2O12;EST2OO3;POL2OO3;IRL1972;SLK2OO3; } \\
\text { CZE2OO3,HUN2OO3,LAT2OO3,LIT2OO3 }\end{array}$ \\
\hline 4 ECD*ELI*MAJ & 0.934 & 0.910 & 0.472 & 0.051 & $\begin{array}{l}\text { FIN1994,SWI1997; AUS1994,LIE1992,LIE1995; } \\
\text { IRL1972; SLK2OO3; CZE2003,HUN2O03, } \\
\text { LAT2O03, LIT2OO3 }\end{array}$ \\
\hline $5 \mathrm{ECD}^{*} \mathrm{OFF}^{*} \mathrm{REC}$ & 1.000 & 1.000 & 0.354 & 0.051 & $\begin{array}{l}\text { ROM2OO3; EST2OO3; DEN1972; IRL1972; } \\
\text { CZE2OO3,HUN2OO3,LAT2OO3,LIT2OO3 }\end{array}$ \\
\hline \multicolumn{3}{|c|}{ Solution consistency: 0.920} & & PRI: 0.889 & Solution coverage: 0.869 \\
\hline
\end{tabular}

\section{Treaty referendums $(n=16)$}

Intermediate solution: ECD*OFF + ELI*MAJ*ELE* OFF $\rightarrow$ OUT

Cons. PRI Raw cov.Unique cov. Cases covered. Consistency threshold $=0.74$

\begin{tabular}{|c|c|c|c|c|c|}
\hline $1 \mathrm{ECD}^{*} \mathrm{OFF}$ & 0.904 & 0.834 & 0.719 & 0.532 & $\begin{array}{l}\text { DEN1986; FRA1992,IRL1992; DEN1998, } \\
\text { IRL1987,IRL1998,SPA2005; LUX2O05 }\end{array}$ \\
\hline $2 \mathrm{ELI}^{*} \mathrm{MAJ}^{*} \mathrm{ELE}^{*} \mathrm{OFF}$ & 0.943 & 0.855 & 0.320 & 0.133 & DEN1993; IRL2OO2 \\
\hline \multicolumn{3}{|c|}{ Solution consistency: 0.899} & \multicolumn{2}{|c|}{ PRI: 0.828} & $n$ coverage: 0.851 \\
\hline
\end{tabular}

\section{Policy referendums $(n=18)$}

Intermediate solution: ECD*eli*MAJ + ecd*MAJ*OFF + ELI*MAJ*ELE $\rightarrow$ OUT

\begin{tabular}{llllll} 
& Cons. & PRI & \multicolumn{2}{l}{ Raw cov. Unique cov. } & Cases covered.Consistency threshold $=0.8$ \\
\hline 1 ECD*eli*MAJ & 0.917 & 0.822 & 0.373 & 0.172 & SWI2005a,SWI2005b,SWI2006; GRC2015 \\
2 ecd*MAJ*OFF & 0.906 & 0.813 & 0.490 & 0.188 & SWI1972; FRA1972,IRL2012,ITA1989 \\
3 ELI*MAJ*LE & 0.954 & 0.898 & 0.355 & 0.154 & SWI2009a,SWI2009b; SWI2000 \\
\hline \multicolumn{2}{l}{ Solution consistency: 0.926} & & PRI: 0.879 & Solution coverage: 0.849 \\
\hline
\end{tabular}

Cases separated by semicolons belong to different truth table rows. Upper-case letters mean the presence of a condition, whereas lower-case characters point to its absence. 
Figure 4.2. Sufficiency analyses for successful referendum outcomes.

a)

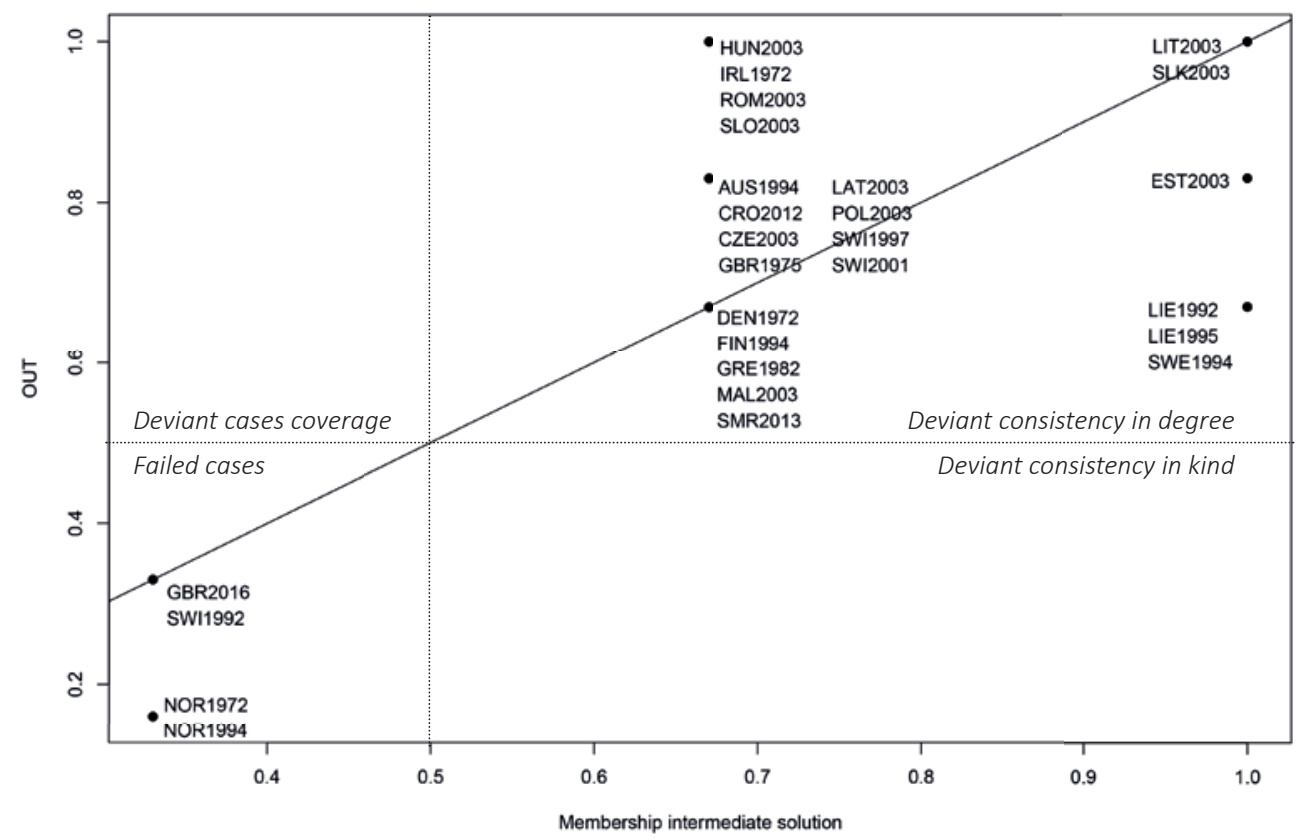

b)

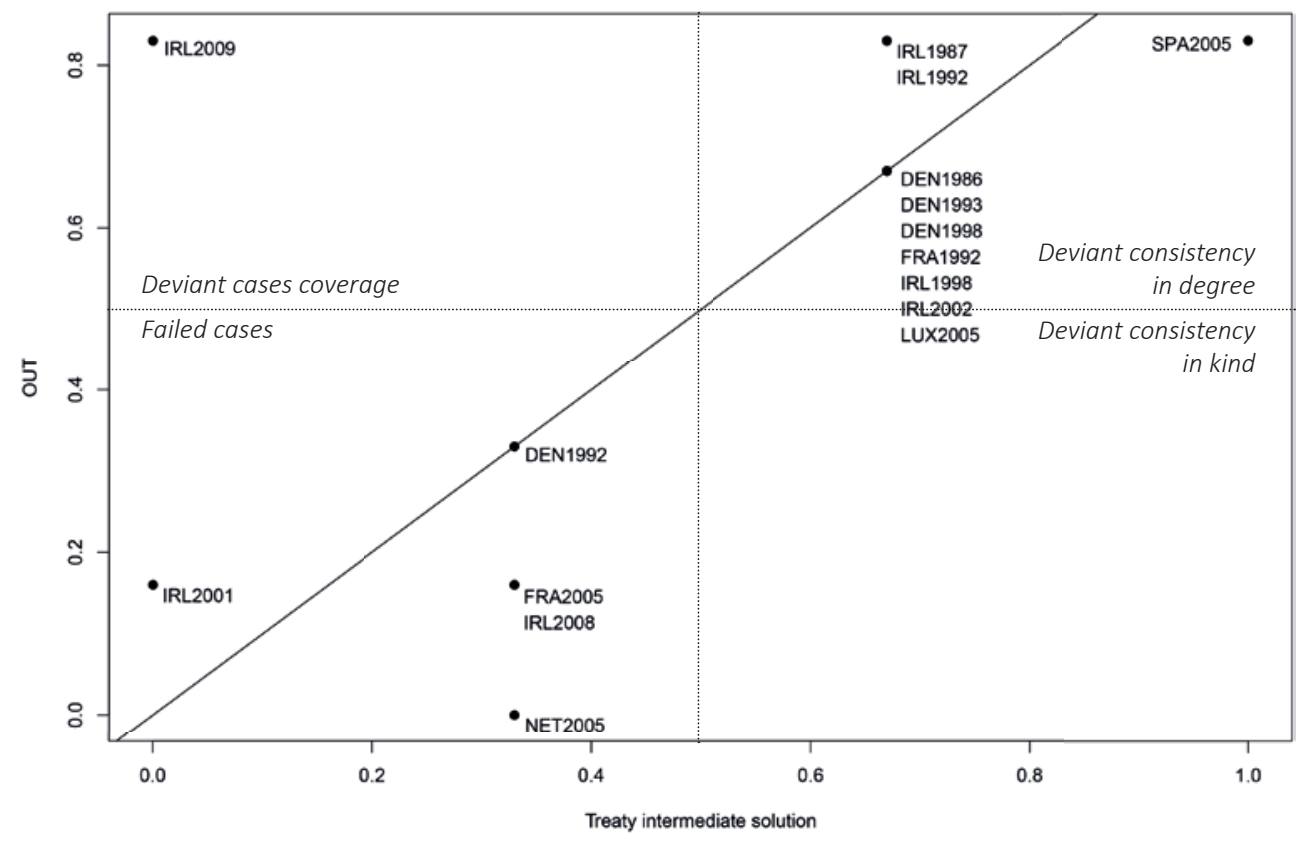


c)

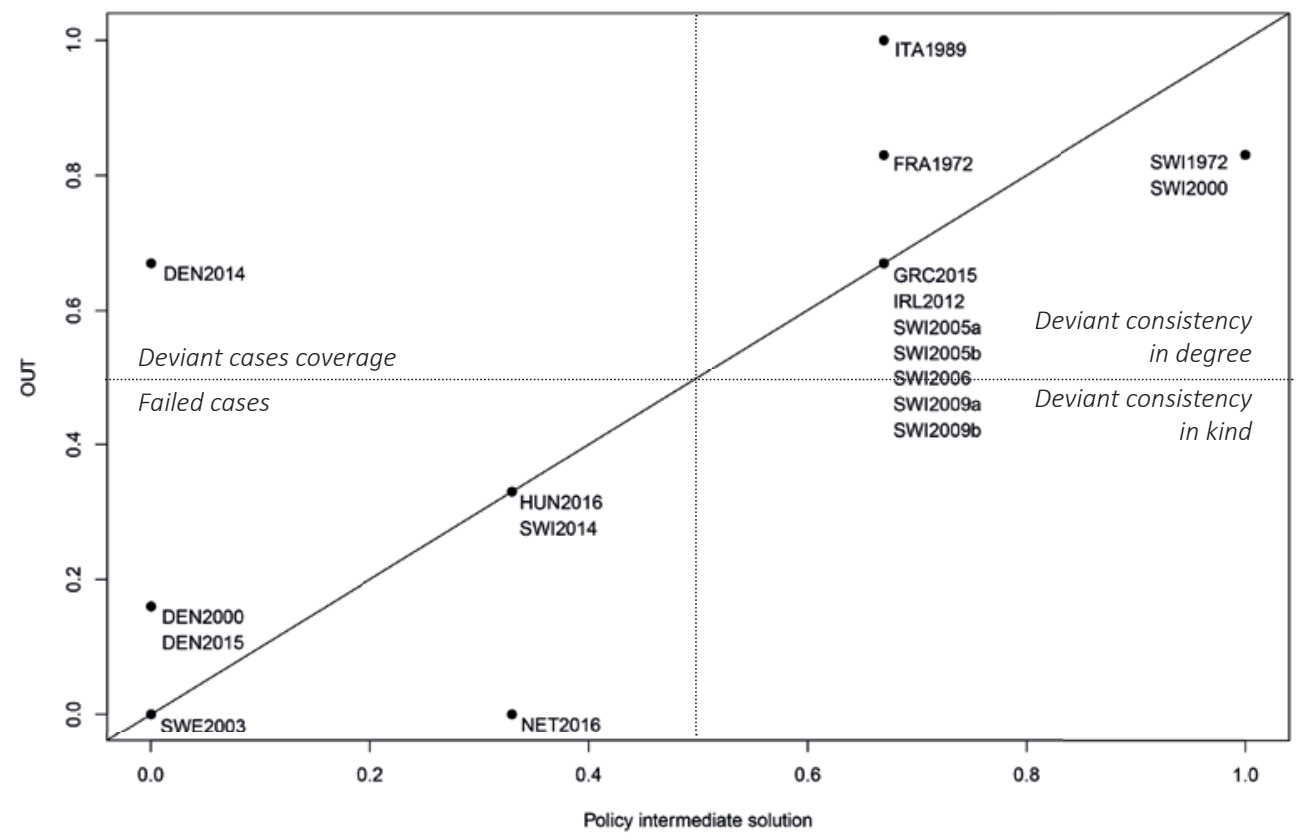

The intermediate solution of the OCA of the 16 treaty referendums provides two paths in which an offensive referendum strategy is a sufficient part of the solution. This is not surprising because this condition is also a necessary condition (see below). Path 1, which covers most successful cases ( 8 out of 11), shows that governments utilise economic prosperity to follow offensive referendum strategies which remit to a successful outcome. Path 2 shows that in absence of such economic prosperity, only an offensive strategy supporting on full political stability during the government's honeymoon contributes to success. The two cases covered by the second path are both 'second' referendums on the same issue which failed one year before: the Danish second referendum on the Maastricht Treaty in 1993 and the Irish second referendum on the Nice Treaty in 2002. One case (Ireland 2009) is not covered by the solution terms as will be discussed in section 5.2.4 on deviant cases. This is also visible in Figure 4.2(b), as it is located in the upper-left quadrant (deviant case coverage).

The intermediate solution of the OCA on policy referendums shows that having a majority government is a sufficient condition in all three solution paths, each time in conjunction with other conditions. Path 3 exclusively covers Swiss popular initiatives. This does not question the analysis as such, since Swiss cases appear empirically more frequent than others. In 2005 and 2006 (path 1) the Swiss and Greek majority governments could rely on economic stability only, even without elite consensus being present. In 2000 and 2009 (path 3), the broad political stability for the Swiss majority government in its honeymoon was sufficient. Path 2 displays that an offensive referendum strategy followed by a majority 
government proves successful even in absence of economic prosperity. One case (Denmark 2014) is deviating in coverage. This case is also located in the upper-left quadrant in Figure $4.2(c)$.

Regarding all solution terms of the three analyses, it is remarkable that all three overall solutions provide for solution terms of solely political factors, or for a conjunction of one or more economical solution term(s) and one or more political solution terms. This shows that just economic favourable circumstances are not sufficient for a win, but need to be accompanied by at least one non-economic factor.

The analyses show that none of the three analyses shows cases of inconsistency in kind (i.e. cases would fulfil the conditions, but do not show the outcome; located in the lower-right quadrant of the plots). This makes the model rather consistent. Though, the analyses show two deviant cases for sufficiency coverage: the Irish second referendum on the Lisbon Treaty in 2009 (IRL2009) and the Danish referendum on its opt-in of the EU Patent Court (DEN2014). Both cases are located in the upper-left corners of Figure 4.2(b) and (c). One approach is to perform case studies and process tracing on the basis of OCA results, which is done extensively in Chapter 5 .

\subsubsection{Necessary conditions}

The feature of necessary conditions is that the outcome can onlyoccurif the condition is present. Theanalysisrevealsthatanoffensivereferendumstrategyis anecessaryconditionforgovernment victory, but only in the set of treaty referendums. Figure 4.3 shows this because 7 cases are located below the diagonal and 3 other cases are only close above the diagonal. This means that a successful outcome of a treaty referendum requires an offensive strategy by the government.

Apart from offensive government strategies in the set of treaty referendums, the analysis reveals no other necessary conditions. Table A4.8 displays the complete analysis of necessary conditions. Values for necessity coverage and relevance necessity generally tend to be higher than 0.5 in order to avoid trivialness (cf. Meyer 2015: 150). Relevance of necessity indicates the irrelevance of necessary conditions that approximate a constant, i.e. they are both necessary for the outcome and the non-outcome (Thomann and Magetti 2017: 18). Although elite consensus seems to be a necessary condition too, it appears evenly necessary for defeated d referendums, and therefore lacks empirical relevance. Also the absence of EU net recipient seems to be a necessary condition in the set of failed membership referendums, but its coverage is too low (0.45). This proves the trivialness of these apparent necessary conditions (Schneider and Wagemann 2012: 278). 
Figure 4.3. Offensive referendum strategy as a necessary condition for successful treaty referendum outcomes.

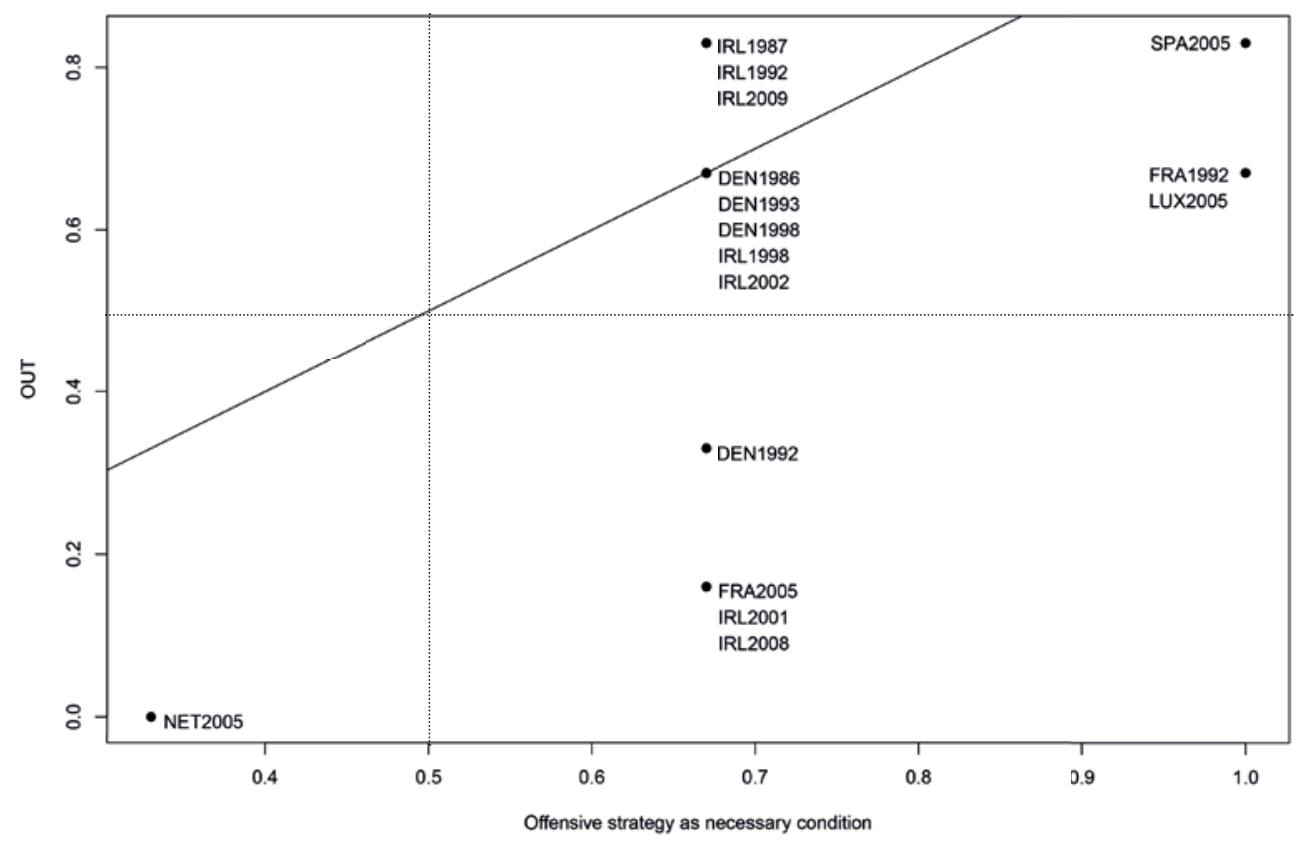


Table 4.4. Sufficiency analyses for unsuccessful referendum outcomes 'out'.

\section{Membership referendums ( $n=27)$}

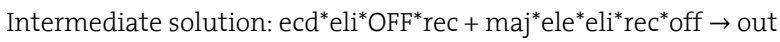

\begin{tabular}{|c|c|c|c|c|c|}
\hline & Cons. & PRI & Raw co & Unique cov. & Cases covered. Consistency threshold $=0.81$ \\
\hline 1 ecd*eli*ele*OFF*rec & 0.879 & 0.641 & 0.324 & 0.209 & SWI1992 \\
\hline 2 maj*ele*eli*rec*off & 0.904 & 0.810 & 0.419 & 0.303 & NOR1972; GBR2016,NOR1994 \\
\hline Solution consistency & & & PRI: 0.7 & & coverage: 0.627 \\
\hline
\end{tabular}

\section{Treaty referendums $(n=16)$}

Intermediate solution: ecd*ele $\rightarrow$ out

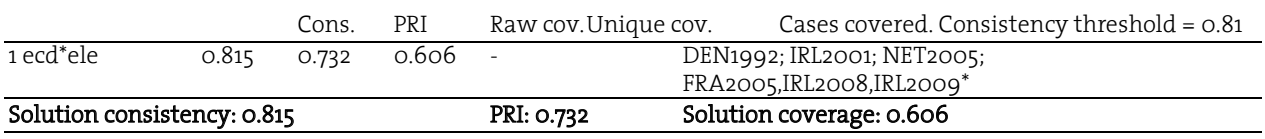

*deviant consistency in kind

\section{Policy referendums $(n=18)$}

Intermediate solution: eli*maj*off + ecd*eli*ele*off + ECD*ELI*MAJ*ele $\rightarrow$ out

\begin{tabular}{|c|c|c|c|c|c|}
\hline & Cons. & PRI & \multicolumn{2}{|c|}{ Raw cov. Unique cov. } & Cases covered. Consistency threshold $=0.81$ \\
\hline 1 eli*maj*off & 1.000 & 1.000 & 0.366 & 0.204 & SWE2003; DEN2O15 \\
\hline 2 ecd $^{*}$ eli $^{*}$ ele*off & 1.000 & 1.000 & 0.244 & 0.042 & SWI2O14 \\
\hline 3 ECD*ELI*MAJ*ele & 0.866 & 0.673 & 0.387 & 0.225 & NET2O16; HUN2O16 \\
\hline
\end{tabular}

\subsubsection{Defeated referendums}

After having revealed what conditions cause government victory, the remaining question is not so much why the opposing side won, but why the government lost. Since configurational approaches do not assume causal symmetry, it is also essential to conduct a OCA analysis for the negation of the outcome (Rihoux and Ragin 2009). The results on the negated outcome enable to crosscheck the findings: are the present conditions which are sufficient and necessary for the outcome (government victory) indeed not in the same way sufficient and necessary for the non-outcome ${ }^{23}$ (Koole and Vis 2012: 18)? The OCA of defeated referendums is reported in Table 4.4. The truth tables are provided in Table A4.5. The analyses show six paths to explain the government's defeat, covering 14 out of 15 lost cases (the remaining case is a deviating case coverage). These paths indeed do indeed not repeat the solution paths of the government's victory, which supports the consistency of the model. It also allows to interpret that there is a clear and relevant distinction between the causal mechanism leading to won or lost referendums. The relevance is confirmed by the high PRI scores (between o.6 and 0.9) of the individual solution paths of both the outcome and the negated outcome. This analysis is however less interpretable from an inductive point of view, due to the limited number of 
defeated cases and hence, limited coverage of the presented solution paths.

The failed membership referendums in Norway, Switzerland and the UK are characterised by the conjunctural absence of at least four factors. Three of the four cases are covered by the second solution path, combining a divided (minority) government, a lack of elite consensus, a government which has been in office for a long time, a (prospective) net contributor and a defensive referendum strategy. These cases are not sharing a deteriorating economic situation (in fact the referendums in Norway 1994 and the UK 2016 featured economic prosperity). This means that the lost referendum issues lacked mainly political support, EU net contributions, and in the Swiss case it also faced a deteriorating economy. The Swiss 1992 EEA accession referendum failed despite the political establishment's offensive to hold it.

The analysis of lost treaty referendums shows that the conjunction of the absence of both recent elections and economic development is sufficient to lose the vote. These two factors cover all five failed cases on the Constitutional Treaty and the treaties of Maastricht, Nice and Lisbon. This implies that in bad economic times when the government's honeymoon is over, it loses treaty referendums. The Irish 2009 referendum is an inconsistency in kind because, in fact, the government won it (see Chapter 5).

Analysing the lost policy referendums provides three solution paths. First, elite polarisation in conjunction with a minority government which deployed a defensive referendum strategy, proves sufficient for the defeated outcome in two cases: the Swedish referendum on the Euro and the Danish referendum on opting-in on Europol lacked full political support. The second path, only covering the Swiss 2014 popular initiative on mass migration, shows that just having a majority government is not enough if political support and the economic situation are weak, and if the government's honeymoon is over. The third path covers the failed referendums in 2016, in the Netherlands on the EU-Ukraine Association Agreement and in Hungary on the proposal for the quota on the resettlement of migrants. It shows that even a combination of economic prosperity, elite consensus and majority government are not sufficient for success, when the government's honeymoon is over. It should be noted however, that the Dutch government was not willing to campaign and only had a tiny majority in the Second Chamber (Lower House). The Hungarian vote resulted in 'defeat' because the turnout threshold was not met. The government was not able to mobilise sufficient voters, when the opposition successfully called to abstain. The Danish 2000 referendum on joining the Euro is a deviant case coverage, meaning that it is not explained by the given solution paths for defeated policy referendums. Its defeat has to be explained by other reasons, which will be explored in Chapter 5 together with the two deviant cases coverage on successful referendums (the Irish 2009 vote on the Lisbon Treaty and the Danish 2014 vote on the European Patent Court).

Looking at all three solution terms across the three types of lost referendums, it is remarkable that both the Swiss EEA referendum (1992) and the popular initiative on mass migration (2014) are characterised by economic deterioration, elite polarisation and a government whose honeymoon is over. The defeated membership referendums in Norway 
and the UK and the two referendums in Denmark (2015) and Sweden (2003) were characterised by elite polarisation and a minority government which deployed the referendum for defensive reasons in order to mask intraparty rifts.

\subsection{Theory evaluation}

The purpose of theory evaluation is to find a plausible interpretation of the solution formulas obtained, backed up by within case analysis (Schneider and Wagemann 2012: 295). The results of the analyses show that explanatory factors do not function in isolation, but rather appear in in conjunctural causation. How do the empirical results overlap with the theoretical propositions as formulated in section 4.1.7?

1. Relying on political stability. It was expected that stable political circumstances (majority government in conjunction with elite consensus) would contribute to a successful outcome. Indeed this conjunction appears in a solution path in each of the three analyses. However, the conjunction does not appear in isolation. In membership referendums the combination appears in conjunction with economic development (path 4: ECD*ELI*MAJ), while in treaty referendums it appears in conjunction with both recent elections and an offensive referendum strategy (path 2: ELI*MAJ*ELE*OFF). In policy referendums it appears in combination with recent elections (path 3: $\mathrm{ecd}^{*} E L I^{*} M A J^{*} \mathrm{ELE}$ ). This suggests that a majority government cannot just rely on elite consensus but needs to be accompanied by either economic prosperity or to enjoy its honeymoon period (and deploy an offensive referendum strategy; in case of a 'second' treaty referendums).

2. Utilising economic prosperity. The second proposition combined economic prosperity with an offensive referendum strategy. It explains successful treaty referendums (path 1: $\left.E C D^{*} O F F\right)$, across membership referendums in conjunction with becoming a net recipient (path 2: $E C D^{*}{ }^{*} E C^{*} O F F$ ). This means that particularly when governments profit from economic upswing, and expecting net gains from EU membership, the offensive move to hold a referendum results in a government victory. In contrast, successful policy referendums are merely explained by factors of government stability (especially the presence of a unified majority government).

The interpretation of the OCAs findings explains under which conditions governments are able to win EU-related referendums (cf. Eder 2010: 63). The findings also shed light on which of the considered factors do not play a role in any solution path. In membership referendums, the six included factors are present across several solution paths. All five included factors (without REC) return in the two solution paths of treaty referendums and in the three solution paths of policy referendums, respectively. Being a net recipient is only a relevant condition in the set of membership referendums. For the lost referendums, the absence of economic prosperity appears across the three referendum types in combination with at least one other factor. However, a minority government, elite polarisation or a defensive referendum strategy do not appear as sufficient conditions in the analysis of lost treaty referendums. 
Although the results of these analyses do not predict every individual (future) EU-related referendum, they allow for modest generalisation (Berg-Schlosser et al. 2009) applicable to those cases reflecting similar circumstances, and contribute to external validity. The intermediate solution, using directional expectations to treat logical remainders, provides an accurate way of substantive interpretability, free from logical contradictions (implausible or untenable configurations). Obviously these explanations have to be linked back to cases because QCA is a 'case-oriented' strategy (Schneider and Wagemann 2012: 28off.). This study's findings may trigger a further examination of EU-related referendums. As Cacciatore et al. acknowledge, as a next step qualitative case studies are "not only needed for cases that are unexplained or explained erroneously, but also for typical cases, ideally covering all explanatory paths" (2015: 1205-6). This next step also enhances the internal validity of the findings.

\subsection{Conclusion}

This chapter assessed under which aggregate conditions governments win EU-related referendums. Out of 61 referendums taking place from 1972 to 2016, more than three-quarters resulted in a victory for the government. In this chapter a model has been developed that explains when referendums are won or lost. The model could correctly explain 44 out of 46 government victories and 14 out of 15 government defeats. To correctly infer the outcome of EU-related referendums based on aggregate level conditions is a new approach in political science literature. So far, referendum results have mainly been traced back to the preferences of individual voters. These individual preferences may explain the effects of certain individual level causes, but do not provide a comprehensive understanding of the causes of an effect: winning or losing the referendum.

In general the analyses reveal that if the economy is booming and the government is unified and has a majority in parliament, the government almost always wins. If the economic situation is deteriorating, however, the largest prospect to win exists if there is a majority government which has been only recently in office and which is backed by large elite consensus in parliament. This shows that economic prosperity and broad political stability are crucial factors for the government to win the vote if they appear in certain combination. A unified majority government and positive economic development are the main drivers contributing to government victory. It seems that these two factors are indispensable: one can hardly win a referendum outcome if both factors are absent in the solution terms. This implies that in economic good times, political unity is not required per se in order to win the referendum. Hence, the argument that EU referendums eventually have to be won by government parties is not the only alternative if the economy is developing well. However, in economic bad times, having a unified majority government or broad elite consensus is essential to win. Without political unity then government victory is hardly possible. Moreover, when governments win treaty referendums, an offensive referendum strategy was required in any case, in most cases in combination with economic development. More specifically, 
the separate analyses of membership, treaty and policy referendums show that the type of the referendum matters as contextual mediating mechanism. In membership referendums, being a prospective EU net recipient explains 15 out of 23 government wins, combined with either a majority government, or in combination with economic prosperity and an offensive referendum strategy. Across treaty and policy referendums, this condition would not make such a difference.

The results allow for modest generalisation applicable to future comparable cases facing similar circumstances as the empirically tested population. This contributes to external validity of this study. It could enhance governments and other political actors, policy makers and citizens to know under what circumstances they can win future EU-related referendums. It must be noted however that the empirical findings are limited. Certain logical combinations of conditions could not be analysed because of limited empirical diversity. Due to the limited number of cases, also a limited number of conditions could be taken into account in order to avoid too much intricacy. Furthermore, due to limited diversity and limited number of defeated cases, the data for the analyses of the governments' lost referendums comprises less richness and results in lower sufficiency coverage. Nevertheless, it can be concluded that these lost referendums were characterised by a lack of broad political support on the issue, particularly when the government's honeymoon is over. The analysis revealed some outliers. The model could not explain the government's victory in the Irish 2009 and Danish 2014 referendums, or the government's defeat in the Danish 2000 referendum. A next step is to further compare the existing deviant case with typical cases in order to enhance the internal validity. The analysis of deviant cases is taken up in the next chapter. 


\section{Appendix: Supplementary tables}

\section{Notes}

1. In case a country has a bicameral system, only government support and elite consensus in the Lower House has been taken into account for this analysis, because this distribution of seats in this chamber reflects the main preceding national election result based on which the government is formed.

2. As Rose notes, the division within the governing Conservative Party was 'the determining factor' for the outcome of the Brexit referendum, rather than the support from UKIP voters to leave (Rose 2018: 10).

3. If indeed EU referendums work as second-order elections, it may be that they only do so in times when general (first-order) elections are far away, and voters have no other first-order opportunity to express their view on the national government.

4. Morel (2001) has presented four specific reasons why governments decide to initiate referendums. First, governments may want to consolidate their power by calling a referendum that they feel relatively certain will pass. Second, referendums may be used to resolve internal divisions within the governing party or coalition of parties. Third, referendums may be used to pass treaties that would not otherwise be ratified. Finally, referendums may be 'de facto' obligatory even when they are not constitutionally required.

5. The logic of constitutionality implies that the government has no alternative than to hold the referendum and hence constitutional motives trump all other considerations. Under this logic a referendum could play in four scenarios: when the constitution so requires; when a Court decides that a referendum is constitutionally required; as alternative when the legislature fails to reach the required parliamentary majority; or when a popular initiatives (or popular veto) triggers a referendum on an EU matter. Sometimes a parliamentary minority can also enforce to hold a referendum.

6. The logic of appropriateness is operating when legitimacy concerns are the dominating factor. It is characterised by domestic political pressure exercised on governing elites, sometimes influenced by similar referendums elsewhere (the domino referendum) or precedents, which makes the referendum unavoidable and de facto obligatory. Particularly the announced referendums on the Constitutional Treaty seem to have stimulated a discourse towards constitutional procedures for ratification, linking the Treaty to referendums. Governments in Spain, France, Portugal, Poland, Luxembourg and a Dutch parliamentary majority appealed to the argument that the Treaty represented a qualitative change in the European integration process which required direct legitimation by its citizens (Closa 2007).

7. Several authors for instance discussed the considerations of governments whether or not to call EU referendums on the European Constitution (Closa 2007, Dür and Mateo 2011, Prosser 2016).

8. The order of referendums on the Constitutional Treaty placed pro-integration states first and those with less enthusiastic public opinion after (with the British last in the series), with the implicit intention of provoking a positive domino effect (Closa 2013: 162). 
9. Cf. Qvortrup (2016) only includes EU-related referendums in current EU member states ( $\mathrm{n}=43$ ).

10. A prima facie calculation of government majorities and parliamentary support gives an indication of the direction of the variation the variables majority government and elite consensus might show: the average support for majority governments in successful cases was 0.61 , while the average support for unsuccessful cases was 0.47 ; the average parliamentary support for successful cases was 0.81 , while the average for unsuccessful cases was 0.73 .

11. The collected data on the cases, conditions and the way they are calibrated in fsOCA is provided in the Appendix in order to demonstrate reliability of the study and replicability of the analyses. The tables contain: raw data per condition (A4.1), the calibrated fuzzy data (A4.2), the descriptive statistics of the raw data (A4.3), truth tables (A4.4 and A4.5) conservative and parsimonious solutions, simplifying assumptions (A4.6 and A4.7) and analysis of necessary conditions (A4.8).

12. DEN1993: although no elections took place, the Danish coalition government including the prime minister changed completely, so the new government was still enjoying its 'honeymoon'.

13. Equifinality refers to the fact that there are various explanatory 'paths' that can count as sufficient conditions for the outcome (Cacciatore et al. 2015: 1205).

14. Consistency expresses the degree to which the observations are in line with the statement of sufficiency or necessity, whereas coverage expresses how much of the empirical evidence is explained by the model (Thomann 2015: 1376-7). Following the standards of good practice, consistency sufficiency should not be below 0.75 , while consistency necessity should not be below 0.9 (Schneider and Wagemann 2012).

15. Directional expectations are based on theoretical and empirical knowledge, help to distinguish plausible (easy) from implausible (difficult counterfactuals) (Thomann and Magetti 2017: 16). These directional expectations give the intermediate solution an advantage over both the complex and the parsimonious solution. The complex solution, on the one hand, is only based on empirically observed truth table rows and includes all solution paths hardly without logical minimization using logical remainders. This makes the complex solution quite difficult to interpret. The parsimonious solution, on the other hand, includes also untenable assumptions (so-called difficult counterfactuals) of logical remainders in the solution paths, in order to maximize parsimony. The intermediate solution both simplifies the conservative solution term, but only as such based on theoretical knowledge on the logical remainders, relying on tenable assumptions (so-called easy counterfactuals). The simplifying assumptions for each analysis are reported in the Appendix tables A4.6 and A4.7, indicating which of them constitutes easy counterfactuals.

16. OCA assesses all logical possible combinations of conditions. Six conditions would provide a property space of not less than $26(=64)$ different logical combinations. Non empirically observed logical combinations of truth table rows are called 'logical remainders'. The consistency thresholds are set about 0.8 , depending on a substantially large 'gap' of consistency values between the truth table rows. Truth table rows passing the consistency threshold are coded 1 , values below are coded $\mathrm{o}$.

17. In Switzerland and Liechtenstein, three of these referendums dealt with EEA membership instead of EU membership or candidature.

18. Some membership cases are even explained by 4 out of 5 solution paths: CZE2003, SLK2003, 
LAT2003, LIT2003,HUN2003. These are all 2003 membership referendums, in which many of the six favourable conditions were present.

19. It both passes the consistency threshold of 0.9 and displays a coverage of $>0.6$ and a relevance of necessity of $>0.5$.

20. The bivariate analysis also shows in that 10 out of 11 treaty referendums that the government won an offensive referendum strategy was employed.

21. Elite consensus has a consistency of 0.92 but its relevance is only 0.26 . Notably, elite consensus also seems a necessary condition for the non-outcome ( 0.91 consistency), but without the passing the coverage and relevance standards (0.46 and 0.21$)$.

22. This would mean that the solution path of the outcome is not mirrored in the solution path of the non-outcome (e.g. if $\mathrm{X}$ is a sufficient condition for outcome $\mathrm{Y}$; it does not imply that non-X is a sufficient condition for non-Y). 


\section{Why are some cases deviant?}

The analyses of EU-related referendums in the previous chapter revealed that a unified majority government and economic prosperity are two driving factors across the 10 solution paths of the causal mechanism to a successful outcome. The three analyses of government victory provided a total number of 10 solution paths which could explain 44 out of 46 successful outcomes. The three analyses of government defeat provided six solution paths which could explain 14 out of 15 unsuccessful cases. This means that the solution terms cover most cases but not all of them: the deviating cases should be explained by alternative factors. The three deviant successful cases are the (second) Irish referendum on the Lisbon Treaty in 2009, the Danish referendum on the EU Patent Court in 2014, and the Danish referendum on the Euro in 2000. These cases did not fit any of the solution paths: even the absence of economic prosperity may result in a government victory in one case, while the presence of this economic prosperity in another case may result in a government defeat. ${ }^{24}$ The key goals of case studies grounded in a cross-case analysis are to analyse causal mechanisms linking the cause to the outcome in typical cases and to engage in exploratory research addressing the puzzle of deviant cases (Schneider and Rohlfing 2016: 527). This chapter addresses the second goal by engaging in process tracing in order to refine the explanatory model. The next section discusses the theoretical approach of Comparative Process Tracing (CPT), after which the typical cases of each solution path (configuration) are unfolded in order to show in what way they differ from the deviant cases. The three deviant cases are analysed by comparing these cases to the provided solution terms.

\subsection{Comparative Process Tracing}

Process tracing aims to work out how the configuration actually causes the outcome and to refine the causal mechanism by explaining the cases which are not covered by the OCA solutions. ${ }^{25}$ Hence, causality in process tracing refers to a mechanism-centred understanding of the relation between causes and effect. Moreover, by knowing the causal processes operative in a typical case, one can discern why another a-typical case is deviant (Schneider and Rohlfing 2013: 569). In contrast to techniques such as OCA, Comparative Process Tracing does not only reveal the necessary and sufficient conditions to enable the outcome, but also when and how these conditions have to be brought together to create this outcome. Because causal-process tracing and QCA are both based on configurational thinking, it seems adequate to use CPT in order to explore the internal validity of the findings of a prior OCA study (Blatter and Haverland 2012: 81, 207).

CPT can be approached from a theory-testing or theory-building framework. In a theory-testing framework there are theoretical expectations on the causal mechanism of how configurations will cause the outcome, whereas in a theory-building framework ${ }^{26}$ one of the aims is to determine these mechanisms (Williams and Gemperle 2017: 128). As in 
this study the new causal mechanisms are to be explored, it approaches CPT from a theorybuilding perspective. CPT could also take into account elements of temporality, in which the timing and sequence of conditions matter in terms of their order and when they occur vis-àvis other conditions. Temporal sequencing of the conditions can be vital for understanding of how this configuration affects the outcome through the causal mechanism (Williams and Gemperle 2017: 123). Hence, via CPT some otherwise deviant cases can be explained by integrating timing and sequencing, while other deviant cases can be explained by adding another condition.

Could the timing and sequencing be useful for this study's process tracing? In order to answer this question, two aspects need to be considered. First, in this study the selected conditions do not matter in terms of timing and sequencing vis-à-vis each other: all conditions are assumed to be taken into account within the period of one year preceding the referendum vote (e.g. economic development does not occur before or after elite consensus). Second, in theory-building frameworks there is less knowledge on the sequence of (conjunctions of) the various conditions than in theory-testing frameworks. As the aim of this chapter has a theory-building approach, temporal sequencing is difficult apply to these cases.

\subsection{Types of cases in post-QCA analysis}

Before analysing the three deviant cases, first the different kinds of cases have to be explained. In fsOCA, five types of cases can be distinguished: typical cases, deviant cases for consistency in kind, deviant cases for consistency in degree, deviant cases for coverage and irrelevant cases. In fact those irrelevant cases are relevant, because they are the opposite of the typical cases. Furthermore, within the category of typical cases one can distinguish between uniquely and jointly typical cases. The (sub)categories are discussed below.

\subsubsection{Typical cases}

Cases are typical when they adhere to the theory underlying the empirical analysis i.e. they are 'representative' of the theory. Tracing typical cases is useful because by showing the pattern of ordinary cases, it becomes clear in what respect extraordinary cases are deviant.

The evidence at hand in the typical case should validate the stipulated causal mechanism (Seawright and Gerring 2008: 299). A case is uniquely typical if it has a membership of $>0.5$ in only one solution term. In contrast, a case is jointly typical if it is a member of at least two solution terms (Schneider and Rohlfing 2016: 532). The most typical cases are those "which are on or at least closest to the diagonal as the outcome membership score matches the membership score in the condition" (Williams and Gemperle 2017: 125). ${ }^{27}$ The closer to the upper-right corner, the more typical it is ${ }^{28}$ (see e.g. Figure 4.2). Table 5.1 shows the types based on the presence or absence of the conditions and the outcome. 
Table 5.1. Types of cases classified by the conditions and the outcome in fuzzy sets.

\begin{tabular}{r|l|r|} 
& $\mathrm{X}=$ o condition(s) absent & $\mathrm{X}=1$ condition(s) present \\
\hline $\begin{array}{r}\mathrm{Y}=1 \\
\text { outcome } \\
\text { present }\end{array}$ & 4.Deviant case coverage & 1.Typical cases \\
\hline $\begin{array}{r}\mathrm{Y}=0 \\
\text { outcome } \\
\text { absent }\end{array}$ & 5. Irrelevant cases & 2.Deviant consistency in degree \\
\hline & & 3.Deviant consistency in kind \\
\hline
\end{tabular}

\subsubsection{Deviant cases of consistency in degree}

The deviant cases of consistency in degree also fall in the upper-right quadrant, but below the diagonal. These cases are not typical, but express that the case scores higher on the condition (X) than on the outcome (Y), but both have membership scores of $>0.5$.

\subsubsection{Deviant cases of consistency in kind}

Deviant consistencies in kind are deviant because they meet all conditions for a successful outcome, but show an unsuccessful outcome. This may be caused by conditions missing from the configuration based on theoretical expectations. Moreover it is possible that omitted conditions are found during process tracing, so the omitted condition should be present for the deviant case of consistency, but not for the negative case. The theory-building approach to resolve this case is to compare it with a positive typical case and to refine the causal mechanism (Williams and Gemperle 2017: 126-30)29

\subsubsection{Deviant cases for coverage}

Deviant cases coverage exists due to the under-fitting of the OCA solution. These cases should not have the outcome present according to the theory, but due to another yet omitted condition or solution path have the outcome occurring. Although this does not undermine the theoretical argument of the solution terms, the deviant cases reduce the coverage of the OCA solution, as these cases demonstrate instances in which the outcome cannot be explained by the suggested configurations. Process tracing aims to identify the missing solution path(s) for the deviant cases for coverage, explaining why the outcome occurs in this deviant case, but does not occur in the negative case(s) (Schneider and Rohlfing 2013: 573-4). These conditions could be added to the existing solution paths, or point to a completely new path (Williams and Gemperle 2017: 132).

The case is described best by the conjunction of the truth table row to which the case belongs, as it cannot be explained by the given solution terms. The deviant case is process traced compared to a case from the same truth table row, which shows the non-outcome. 
These two cases should have similar values in the row and a maximum difference in the membership in the outcome (Schneider and Rohlfing 2013: 588). Deviant cases for coverage falling into different truth table rows need to be analysed separately. ${ }^{30}$ Schneider and Rohlfing claim that the scope of causal inference is limited to all deviant cases of the same type on the same truth table rows (Schneider and Rohlfing 2016: 541-2). Cases belonging to different truth table rows are therefore qualitatively different, compared to cases that belong to the same truth table row. As stated before, process tracing should identify a condition that is missing from this truth table row. Once included in the truth table row, it separates the deviant case coverage from the other cases, which then fall into different truth table rows. The deviant case turns into a typical case in its (new) row, while the negative cases remain in the other row(s) (Schneider and Rohlfing 2013: 574). A limitation of this approach is that the number of conditions cannot be endlessly extended vis-à-vis the number of cases.

\subsubsection{Irrelevant cases}

Cases in the lower left corner of the XY plot hold low membership values in both the outcome and the solution: they are neither member of the solution term(s) nor member of the outcome. These cases can thus be considered largely 'irrelevant' for the theoretical argument of sufficiency and necessity for the outcome (because these cases fall below the consistency threshold and hence do not play a role in the OCA of the outcome). Nevertheless, these cases are relevant for the analysis of the non-outcome when they could turn into typical cases (Schneider and Rohlfing 2013: 588).

\subsection{Tracing types of cases}

Using the plots of the three analyses (see Chapter 4), all 61 cases can be classified in this fivefold typology (see Table 5.2). 
Table 5.2a. Types of cases in Membership referendums.

\begin{tabular}{|c|c|c|c|c|c|c|}
\hline & $\begin{array}{l}\text { Uniquely } \\
\text { typical }\end{array}$ & $\begin{array}{l}\text { Jointly } \\
\text { typical }\end{array}$ & $\begin{array}{l}\text { Deviant } \\
\text { consistency } \\
\text { in kind }\end{array}$ & $\begin{array}{l}\text { Deviant } \\
\text { consistency } \\
\text { in degree }\end{array}$ & $\begin{array}{l}\text { Deviant } \\
\text { cases } \\
\text { coverage }\end{array}$ & $\begin{array}{l}\text { Irrelevant } \\
\text { cases }\end{array}$ \\
\hline $\begin{array}{l}\text { Member of term } \\
\text { 1: ECD*ELE }\end{array}$ & & $\begin{array}{l}\text { CZE20O3; } \\
\text { HUN2OO3, } \\
\text { SMR2O13; } \\
\text { SLK2O03; } \\
\text { LAT2OO3, } \\
\text { LIT2OO3 }\end{array}$ & & $\begin{array}{l}\text { SWE1994 } \\
\text { EST2003 }\end{array}$ & & \\
\hline $\begin{array}{l}\text { Member of term } \\
\text { 2: MAJ*off }\end{array}$ & SWI2001; & $\begin{array}{l}\text { SMR2O13; } \\
\text { SLK2OO3; } \\
\text { GBR1975; } \\
\text { FIN1994; } \\
\text { SWI1997; } \\
\text { POL2003; }\end{array}$ & & EST2003 & & \\
\hline $\begin{array}{l}\text { Member of term } \\
\text { 3: MAJ*REC }\end{array}$ & $\begin{array}{l}\text { GRE1982, } \\
\text { MAL2OO3; } \\
\text { SLO2OO3; } \\
\text { CRO2O12; }\end{array}$ & $\begin{array}{l}\text { CZE2003; } \\
\text { SLK2OO3; } \\
\text { HUN2003, } \\
\text { LAT2003; } \\
\text { LIT2OO3; } \\
\text { GBR1975; } \\
\text { POL2OO3; } \\
\text { IRL1972; }\end{array}$ & & EST2003 & & \\
\hline $\begin{array}{l}\text { Member of } \\
\text { term } 4 \text { : } \\
\text { ECD }{ }^{*} L^{*} M A J\end{array}$ & AUS1994, & $\begin{array}{l}\text { CZE2003; } \\
\text { SLK2OO3; } \\
\text { HUN2003, } \\
\text { LAT2003; } \\
\text { LIT2003; } \\
\text { FIN1994; } \\
\text { SWI1997; } \\
\text { IRL1972; }\end{array}$ & & $\begin{array}{l}\text { LIE1992, } \\
\text { LIE1995; }\end{array}$ & & \\
\hline $\begin{array}{l}\text { Member of } \\
\text { term 5: } \\
\text { ECD*OFF* } \\
\text { REC }\end{array}$ & $\begin{array}{l}\text { ROM2OO3; } \\
\text { DEN1972 }\end{array}$ & $\begin{array}{l}\text { CZE2003, } \\
\text { HUN2OO3, } \\
\text { IRL1972, } \\
\text { LAT2O03, } \\
\text { LIT2OO3 }\end{array}$ & & EST2003 & & \\
\hline $\begin{array}{l}\text { Non-member } \\
\text { solution }\end{array}$ & & & & & & $\begin{array}{l}\text { GBR2O16 } \\
\text { NOR1972 } \\
\text { NOR1994 } \\
\text { SWI1992 }\end{array}$ \\
\hline
\end{tabular}


Table 5.2b. Types of cases in Treaty referendums.

\begin{tabular}{|c|c|c|c|c|c|c|}
\hline & $\begin{array}{l}\text { Uniquely } \\
\text { typical }\end{array}$ & $\begin{array}{l}\text { Jointly } \\
\text { typical }\end{array}$ & $\begin{array}{l}\text { Deviant } \\
\text { consistency } \\
\text { in kind }\end{array}$ & $\begin{array}{l}\text { Deviant } \\
\text { consistency } \\
\text { in degree }\end{array}$ & $\begin{array}{l}\text { Deviant } \\
\text { cases } \\
\text { coverage }\end{array}$ & $\begin{array}{l}\text { Irrelevant } \\
\text { cases }\end{array}$ \\
\hline $\begin{array}{l}\text { Member of } \\
\text { term 1: } \\
\text { ECD*OFF }\end{array}$ & $\begin{array}{l}\text { DEN1986; } \\
\text { FRA1992, } \\
\text { IRL1992; } \\
\text { DEN1998, } \\
\text { IRL1987, } \\
\text { IRL1998; } \\
\text { LUX2005 }\end{array}$ & & & SPA2OO5 & & \\
\hline $\begin{array}{l}\text { Member of } \\
\text { term 2: } \\
\text { ELEE ELI* }^{*} \\
\text { MAJ }^{*} \text { OFF }\end{array}$ & $\begin{array}{l}\text { DEN1993; } \\
\text { IRL2OO2 }\end{array}$ & & & & & \\
\hline $\begin{array}{l}\text { Non-member } \\
\text { solution }\end{array}$ & & & & & IRL2009 & $\begin{array}{l}\text { DEN1992, } \\
\text { FRA2O05 } \\
\text { IRL2001, } \\
\text { IRL2008 } \\
\text { NET2005 }\end{array}$ \\
\hline
\end{tabular}

Table 5.2c. Types of cases in Policy referendums.

\begin{tabular}{|c|c|c|c|c|c|c|}
\hline & $\begin{array}{l}\text { Uniquely } \\
\text { typical }\end{array}$ & $\begin{array}{l}\text { Jointly } \\
\text { typical }\end{array}$ & $\begin{array}{l}\text { Deviant } \\
\text { consistency } \\
\text { in kind }\end{array}$ & $\begin{array}{l}\text { Deviant } \\
\text { consistency } \\
\text { in degree }\end{array}$ & $\begin{array}{l}\text { Deviant } \\
\text { cases } \\
\text { coverage }\end{array}$ & $\begin{array}{l}\text { Irrelevant } \\
\text { cases }\end{array}$ \\
\hline $\begin{array}{l}\text { Member of term } \\
\text { 1: ECD*eli*MAJ }\end{array}$ & $\begin{array}{l}\text { SWI2005a, } \\
\text { SWI2005b, } \\
\text { SWI2006; } \\
\text { GRC2015 }\end{array}$ & GRC2O15 & & $\begin{array}{l}\text { SWI2009a } \\
\text { SWI2009b }\end{array}$ & & \\
\hline $\begin{array}{l}\text { Member of } \\
\text { term 2: } \\
\text { ecd*MAJ*OFF }\end{array}$ & $\begin{array}{l}\text { SWI1972; } \\
\text { FRA1972, } \\
\text { IRL2O12, } \\
\text { ITA1989 }\end{array}$ & & & $\begin{array}{l}\text { IRL2O12 } \\
\text { SWI2009a } \\
\text { SWI2009b }\end{array}$ & & \\
\hline $\begin{array}{l}\text { Member of term } \\
\text { 3: ELI*MAJ*ELE }\end{array}$ & $\begin{array}{l}\text { SWI2009a, } \\
\text { SWI2009b; } \\
\text { SWI2000 }\end{array}$ & GRC2O15 & & SWI2006 & & \\
\hline $\begin{array}{l}\text { Non-member } \\
\text { solution }\end{array}$ & & & & & DEN2O14 & $\begin{array}{l}\text { DEN2000, } \\
\text { DEN2015 } \\
\text { NET2016, } \\
\text { SWE2003 } \\
\text { SWI2014 }\end{array}$ \\
\hline
\end{tabular}

As the aim of this chapter is to unravel the deviant cases, it goes beyond its scope to extensively analyse all ten solution terms. Therefore, the tracing of cases is limited to (uniquely or jointly) typical cases and deviant cases coverage in order to unravel the most important differences between the two. The cases deviant consistency in kind, deviant consistency in degree and irrelevant cases are not extensively analysed. Furthermore, the aspect of temporality and sequence does not seem to be that relevant, because all included conditions are taken into account at more or less the same point in time: the voting day. ${ }^{8}$ 


\subsubsection{Typical cases}

This section process traces one typical case per solution term; if possible one uniquely typical case (i.e. present in one solution term) or alternatively one jointly typical case (appearing in multiple solution terms). All uniquely typical cases are listed and shortly discussed in the Appendix.

Starting with membership referendums, the first term -economic prosperity in combination with recent elections- covers eight cases, of which none is uniquely typical, however. Therefore, two jointly typical cases are taken: the two membership referendums in Lithuania and Slovakia in 2003. This term implies that the newly elected governments could rely on broad popular support in the accession referendum, while enjoying economic bright times. Both governments received very high approval rates in favour of membership of more than 90 percent. The second term -having a majority government confronted with a defensive referendum strategy- contains the Swiss 2001 referendum as most uniquely typical case. The Swiss government withstood the popular initiative by keeping the political establishment massively against Swiss participation in the European integration process (the initiative strived for EU membership and forced the immediate start of accession negotiations): more than three-quarters of the Swiss voters supported the government and voted against the initiative. The third solution path -having a majority government combined with becoming an EU net recipient- picks inter alia the Maltese 2003 accession vote as most uniquely typical case. Although the Maltese majority government was united in favour, the membership issue was politically divisive as the main opposition party fiercely campaigned against it. While calling the referendum, before the elections, the governing PN wanted to maximize its electoral chances. As the arguments dominating the campaign focused on the potential economic costs and benefits of joining the larger trade block, the prospective of becoming a net recipient of EU funds, may have been a valuable argument for the Yes camp (Cini 2004: 589). The fourth term (economic prosperity combined with a majority government and elite consensus) identifies the Austrian 1994 membership referendum as uniquely typical. Although the Nordic enlargement was also driven by security reasons after the end of the Cold War, this case shows that even without becoming an EU net recipient, broad political consensus and bright economic development form a stable avenue for popular support for EU membership. The fifth configuration -economic prosperity combined with becoming a net recipient and an offensive referendum strategy- has the Danish 1972 accession vote as most typical case. This mechanism demonstrates that even without having a majority government, in times of economic prosperity and the prospect of becoming a net recipient were sufficient for the Danish government to pass the constitutionally required referendum hurdle, as the necessary five-sixth parliamentary majority was not reached.

The OCA of treaty referendums reveals two configurations. The first one -economic prosperity combined with an offensive strategy- displays the French 1992 vote on the Maastricht Treaty as one of the most uniquely typical cases. President Mitterrand used his prerogative power to announce a referendum in order to strengthen his own position at the expense of his political opponents. The membership score 
in the configuration and the outcome of both 0.67 however show that economic figures were not that bright to foster a large victory. Instead, Mitterrand just survived the Maastricht referendum with 51 percent support. The second configuration combines all four political conditions (elite support, majority government, recent elections, and offensive strategy). It identifies the second Danish referendum on the Maastricht Treaty and the second Irish referendum on the Nice Treaty as uniquely typical. These cases show that broad and favourable political circumstances are required in order to obtain sufficient Yes vote in the 'second referendum', irrespective of the economic circumstances.

The policy referendums' QCA provided three solution terms. The first configuration -economic prosperity combined with a majority government in the absence of elite consensus- shows the Greek 2015 'Euro bailout' referendum as one of the most uniquely typical cases (in fact, all four cases in this configuration are evenly typical). Although Greek Prime Minister Tsipras relied on his majority government, the support risked falling apart when the non-implementation of the EU's austerity programmes almost led to an economic meltdown of the country in June 2015, despite the fact that the economy was recovering compared to 2014. When he suddenly announced to hold a referendum in order to strengthen his position in both Athens and Brussels against the imposed bailout and austerity package of the 'troika' (European Commission, ECB and IMF), the anti-Brussels frame probably pushed sufficient voters on Tsipras' side. Despite the high polarisation on the issue, Tsipras managed to acquire a majority of 60 percent against the troika's draft proposals.

The Swiss typical cases reflect willingness of a majority of Swiss voters to support their government in the three integration proposals in 2005-2006, despite the popular initiatives attempting to block these issues: joining the Schengen area, regulating the free movement of persons, and organising further cooperation with the recently acceded CEECs.

The second solution term -the absence of economic prosperity, majority government and an offensive strategy- depicts the Irish 2012 vote on the Treaty on Stability and Governance of the EMU as most uniquely typical case. This referendum was constitutionally required, while the Irish economy was still in a state of crisis. Also because the Irish economy had benefited from one of the first rescue packages of the EU and the IMF in 2010, a majority of the Irish voters was willing to support the treaty on this issue.

The third solution path -elite consensus combined with a majority government and recent elections- shows that the Swiss majority government was enjoying its honeymoon period and relying on broad political consensus while facing popular initiatives on EU matters. The evenly two uniquely Swiss typical cases of 2009, on the EU policy on biometrical passports, and on the free movement of persons with Bulgaria and Romania, demonstrate that a majority of the Swiss was willing to support the government despite these opposing popular initiatives. Finally, it is remarkable that the three provided configurations all contain majority government as a condition. This implies that successful minority governments would have to rely on alternative configurations, as is the case with the Danish 2014 referendum, as discussed in the next section. 


\subsubsection{Deviant cases coverage}

For the successful outcome, there is one deviating case in the set of treaty referendums (IRL2009) and one deviating case in the set of successful policy referendums (DEN2014). In the $\mathrm{XY}$ plots these cases are located in the upper left square, because they were successful without following provided solution paths. There is one deviating case in the set of unsuccessful policy referendums (DEN2OOO), which will be shortly discussed as has been explained in section 5.1.

Table 5.3. Deviant cases coverage.

Treaty referendums

\begin{tabular}{llllllll}
\hline Truth table row & ECD & ELI & MAJ & ELE & OFF & OUT & Same truth table row cases \\
\hline 14. IRL2009 & 0 & 1 & 1 & 0 & 1 & 0.83 & FRA2005,IRL2008 \\
\hline
\end{tabular}

Policy referendums

\begin{tabular}{llllllll} 
Truth table row & ECD & ELI & MAJ & ELE & OFF & OUT & Same truth table row cases \\
\hline 4. DEN2O14 & 1 & 1 & 0 & 0 & 1 & 0.67 & DEN2OOO \\
\hline
\end{tabular}

Following Schneider and Rohlfing (2016), an XY plot of the truth table row of each deviant case coverage can be provided if the truth table row contains at least two deviant cases coverage. As both deviant cases are the only deviant case, no separate XY-plot needs to be constructed.

Since none of the deviant cases coverage belongs to the same truth table row as another deviant case coverage, the next step is to look for a distinguishing, omitted, condition. This omitted condition would turn the deviating case coverage into a typical case, while the irrelevant (i.e. non-successful) cases of the same truth table row remain irrelevant. This will be done for the two deviant cases coverage. Table 5.3 shows that the deviating cases are not the only ones on their particular truth table row. They share their properties (roughly) with at least one other case:

The Irish 2009 referendum shares the same features as the Irish referendum in 2008 and the French referendum in 2005: negative economic development, elite consensus, a majority government, a government which has been long in office and an offensive referendum pledge.

The Danish 2014 referendum shares its features with the Danish 2000 referendum: positive economic development, considerable elite consensus, a minority government, a government which has been recently in office, and an offensive referendum pledge.

The Danish 2000 referendum (deviating as unsuccessful case), in turn, shares its properties with this Danish 2014 referendum. Hence, if an additional factor is detected which both explains why one case was won and why the other case was lost, both deviating cases can be resolved. 
Table 5.4. Membership scores of cases in the same truth table row as the deviant cases coverage*.

Truth table row 4 of successful Treaty referendums:

\begin{tabular}{lllllll|l}
\hline & ECD & ELI & MAJ & ELE & OFF & OUT & Economic recovery? \\
\hline FRA2005 & 0.33 & 1 & 1 & 0 & 0.67 & 0.16 & 0 \\
IRL2008 & 0 & 1 & 0.67 & 0.33 & 0.67 & 0.16 & 0 \\
IRL2009* $^{*}$ & 0 & 1 & 0.67 & 0 & 0.67 & 0.83 & 1
\end{tabular}

Truth table row 10 of successful Policy referendums:

\begin{tabular}{lllllll|l}
\hline & ECD & ELI & MAJ & ELE & OFF & OUT & Sovereignty issue? \\
\hline DEN2000 & 1 & 0.67 & 0 & 1 & 0.67 & 0.16 & 1 \\
DEN2O14 $^{*}$ & 1 & 0.67 & 0 & 1 & 0.67 & 0.67 & 0
\end{tabular}

Table 5.4 shows the specific membership scores of the cases per condition in the same truth table row as the deviant case. Apart from the outcome, there are logically only marginal differences across the same truth table rows.

\subsection{Deviant case analysis}

\subsubsection{Ireland 2009: economic recovery}

As revealed in Chapter 4, governments win treaty referendums if either positive economic development is combined with an offensive referendum strategy; or if elite consensus is combined with a majority government, recent elections and an offensive referendum strategy. Ireland did not fit to the first solution term given the economic crisis (it did not experience positive economic development). It did neither fit to the second solution term, since the government had been in office for a long time (it did not enjoy its honeymoon). How can the successful Irish 2009 referendum on the Lisbon Treaty be explained if it did not fit any of the provided solution terms?

To resolve this question, other causal explanations have to be explored, which could also be tested on the other cases in same the truth table row. One appealing explanatory theoretical argument could be the so-called economic recovery hypothesis. It claims that high employment, low inflation and affluence are supposed to bolster the status quo, while economic hardship makes people to vote for change. This occurred during the membership referendums in 1994 when the Finnish and Swedish voted for EU membership, while the better-off Norwegian voters preferred to remain outside the Union (Jenssen et al.1998: 195). A majority of the Finns and Swedes saw EU membership as a possibility for economic recovery and prosperity, especially with regard to the national economy.

Jensen's argument of the Swedish and Finnish accession referendums in 1994 may 
be well applicable to the situation in Ireland in 2009. The more pressing a country's current economic problems are, the more willing its citizens will be to accept permanent international commitments (Jenssen et al. 1998: 30). The economic crisis had hit Ireland severely in 2008: 5.5 percent economic growth in 2007 turned into -2.2 percent in 2008 and even -5.6 percent in 2009, while unemployment doubled from 6.0 percent in 2008 to 12.0 percent in 2009. Like Sweden in 1994, it was not sure whether Ireland could fulfil its financial obligations. If it were to reject the Lisbon Treaty again, Irelands 'safe place' within the Eurozone would be at risk. As Ireland was about to recover from the financial crisis, the consensus among both elite and public opinion was that the EU's more integrative policies for the stability of the economic and monetary union were indispensable for the both the Euro and the Irish economy to survive (De Bruyn 2012, Quinlan 2012). As a result, the economic argument in favour of continued EU membership under the Lisbon Treaty was more prominent and appreciated at the time of the second referendum. Hence, it would make sense to add economic growth and recovery as single, additional condition to the truth table row, being present for the Irish case, while being absent for the Irish 2008 and French 2005 cases. Though this was not the only factor: "The legal guarantees provided to Ireland help the Government reduce fears about Lisbon in terms of sovereignty and military neutrality. The recession and the legal guarantees together defused the spirited no-campaign and put the yes-campaign on the road to success" (De Bruyn 2012: 90).

To confirm that this factor economic recovery distinguishes the Irish 2009 referendum from the other two cases in the same truth table row (the French vote on the Constitutional Treaty in 2005 and the Irish first vote on the Lisbon Treaty in 2008), it has to be tested whether these other cases indeed do not turn into typical cases as well. Although France, and Ireland (as stated) did not enjoy economic prosperity at the time of these referendums, the economic downturn was not as such at the time of the votes (May 2005 and June 2008, respectively) as in Ireland 2009. ${ }^{31}$ France (2005) and Ireland (2008) were not dependent on international European economic support, compared to the bailout and recovery programmes as designed for Greece, Portugal and Ireland during the post-2008 economic crisis. Like in Sweden (and Finland) in 1994, the need to revitalize the Irish economy in order to ease immediate unemployment and budget deficits was much more urgent compared to the preceding referendums 2008 and 2005. Therefore, the economic recovery seems to be an adequate additional condition to resolve this deviant case for coverage. In the Irish case of 2009, the urgent need of economic recovery would trigger a successful outcome in conjunction with elite consensus, majority government and an offensive referendum strategy.

The changed economic circumstances provided the opportunity to the Yes camp to campaign that the EU had a vital role to play in Ireland's economic recovery. Hence, Ireland's EU and Eurozone membership was considered a part of the solution, so in fact, the second referendum would boil down to Ireland's future in or out the EU. 


\subsubsection{Denmark 2014 and Denmark 2000: loss of sovereignty}

The analysis of policy referendums revealed that governments win policy referendums according to three solution terms: first, if they combine a majority government with positive economic development but without elite consensus. Second, in case of a majority government with an offensive referendum strategy but without positive economic development. Third, in case of a majority government which has only been in office a short time, supported by elite consensus on the issue at stake. It is remarkable that all three solution paths include the condition of a majority government, which implies that most won policy referendums were characterised by a majority government. Despite that the Danish government in 2014 was a minority government (as usual in Denmark), it managed to win the policy referendum on Danish accession to the EU's Patent Court. What additional explaining condition for this victory can be identified?

Looking at the truth table row characteristics, the Danish 2014 government victory in 2014 shows many similarities with the Danish defeat in 2000 in which joining the Euro was rejected. (As noted before this case has also been identified as deviating case coverage for defeated referendums.) All conditions reflect almost the same raw data in both cases: minority governments (0.39 percent in $2000 \mathrm{~V}$. 0.34 percent in 2014), a considerable degree of elite consensus ( $0.78 \mathrm{v}$. 0.79 parliamentary support), a government which had been in office for almost three years (932 v. 965 days), increasing economic growth (0.9 v. 1.5 percent), and decreasing unemployment (-0.8 v. -0.5 percent).

Why did the Danes support the Patent Court, but reject to join the Euro? Probably because the subjects differ considerably in terms of a perceived transfer of powers from the national to the EU level: the participation to the European patent court might have been a smaller step for the Danish compared to participation to the Eurozone. Jenssen et al. labelled this the sovereignty hypothesis: citizens of nations-states are very reluctant to transfer any aspects of their country's sovereignty to the supra-national level (Jenssen et al. 1998: 30). Denmark being a well-established, well-functioning nation-state with a strong national identity might oppose the surrender of strong national symbols to the EU. A national currency often marks as a symbol of this national identity, while a patent regime is much less visible in everyday life. How did the sovereignty issue differ between the 2014 and 2000 referendums?

In 2000 the economy was booming and Denmark had met the Maastricht convergence criteria to join the Euro. The Yes parties emphasized the economic aspects of the issue. However, the No camp used the economic upswing to argue that Denmark was better off outside the Eurozone. The economic argument was framed in terms of sovereignty instead: the government's key argument that the single currency would stimulate economic growth, fuel employment and induce economic stability was overturned by the No focus on the loss of national sovereignty and the threat of a political union (Hobolt and Leblond 2009). It was in the No camp's interest to get a broadly defined debate and campaign issue agenda rather than a narrow economic agenda as proposed by the Yes camp. The No side 'diverted' from this economic and financial agenda and worked to achieve a broader definition of the 
referendum issue, applying the strategy of issue diversion. This issue diversion ranged from prospective EU enlargement, political integration in Europe to sovereignty issues, national values, and the expenses related to the physical introduction of the Euro. The Yes side came across as untrustworthy and backfired as simplistic 'one-trick-only' strategy (De Vreese and Semetko 2004: 57-60). One of the main fears was the possible weakening of the generous welfare system. Economic arguments for joining were not convincing to many voters (Miller 2000). Supporting the No case, the Danish Economic Council concluded that economic advantages of joining the Euro were at best 'slight and uncertain'. A Yes or No outcome would not be discernible for the Danish economy. The Euro was considered an elite-driven project, and people felt that staying outside the Euro zone was unlikely to have direct consequences for their country's economy. This perception is in line with the Norwegian considerations against EU membership in 1994: 'we can manage without'. Hence, the perceived loss of sovereignty was a dominant factor in the Danish 2000 referendum.

In 2014, Denmark was recovering from an 'double dip' it had suffered during the economic crisis. However, compared to the Irish 2009 referendum on the Lisbon Treaty, the Patent Court was not debated in terms of the economic recovery hypothesis. The offensive strategy on the EU Patent Court was rather aimed at utilising the moment of economic stability (a solution term that has been revealed for several successful treaty referendums). Both proponents and opponents focused much more on the content of the issue, compared to the issue of EMU membership. The Yes parties used their expertise to present voters a pragmatic vocabulary ('Danish patents stimulate Danish exports') and the need for a uniform European policy, while the No parties illuminated the legal and societal consequences of a European Patent Court (Poulsen and Sander 2016). Hence, the opponents were not able to frame the issue in terms of economic independence, sovereignty national identity. The No camp actually had no convincing counter argument against the massive political and business support in favour of the EU Patent Court.

After having compared the Danish 2000 and 2014 referendums, the perceived loss of sovereignty can be the understood as an -additional- distinctive condition between the two votes. The absence of the perception of a loss of sovereignty would turn the Danish 2014 referendum into a typical case, while the 2000 referendum remains a negative case. Moreover in the analysis of lost policy referendums, this additional condition of sovereignty could turn the deviant Danish 2000 case in a typical defeated case.

\subsection{Conclusion}

This chapter aimed to unravel the puzzle of deviant cases for coverage, as revealed by the analyses of 46 referendums won by the government. The success of the Irish referendum on the Lisbon Treaty (2009) and the Danish referendum on the EU's Patent Court (2014) could not be explained by the solution terms which accounted for the other 44 successful outcomes, as illustrated by the typical case analysis. Moreover, the defeated Danish vote on joining the 
Euro (2000) had some solution terms that were associated with many successful outcomes. Hence, by taking a closer look at these cases and comparing them with some typical cases, it has been tried to find possible other explanatory factors in order to refine the accuracy of the model.

The two deviating successful cases (IRL2009 and DEN2014) shares several characteristics with some unsuccessful cases. The comparison of deviant cases with these lost cases unfolds two additional conditions which can be applied to the cases on the same truth table row and distinguish the successful case from the unsuccessful cases. The economic recovery hypothesis seems to be the most distinguishing factor between the second Irish referendum on the Lisbon Treaty in 2009 on the one hand; and the first Irish referendum on the Lisbon Treaty in 2008, and the French 2005 referendum on the Constitutional Treaty on the other hand. The sovereignty hypothesis seems to make the main difference in the similar context between the Danish referendums on participation to the European Patent Court in 2014 and the participation in the Euro in 2000. For the former the sovereignty issue did not really matter, for the latter it was considered 'a bridge too far'. By adding these two factors to the configuration, the three deviant cases for coverage could be resolved. Moreover, given the increased contestation of European integration concerning the transfer of competences, it might be that the sovereignty factor will acquire a more common place in solution paths. If countries consider that their national sovereignty is at stake, voters would be less willing to support their government in referendums on these sensitive issues, irrespective of the degree of elite support for it or economic prosperity.

\section{Appendix: Uniquely typical cases}

\section{Notes}

1. Regarding the analyses of the government's lost referendums, the OCAs on the negation of the outcome provided the Irish 2009 referendum as deviant case for consistency in kind: it was counterfactually considered as a government loss, while it was a government win. In turn, the Danish 2000 referendum turned out as a deviant case for coverage: it did not fit to the solution paths for failed cases, but nevertheless showed a government loss.

2. Williams and Gemperle (2017) define a causal mechanism as a theoretical formulation, one that adduces properties of the relationships among phenomena with the potential to recur, which helps explain why X causes Y. There is not yet a theory which differentiates between case-specific and more abstract and generalizable processes.

3. Williams and Gemperle have designed a three-step approach for theory building CPT for deviant case coverage: 1) comparatively process trace two uniquely typical cases from each configuration; 2) comparatively process trace the deviant case(s) consistency with a typical cases identified in step 1; 3) comparatively process trace the deviant case(s) coverage with the irrelevant case(s) of the same truth table row and identify omitted conditions. The shortcut of the theory building Comparative 
Process Tracing framework is to only process trace one case study in Step 1 (ideal typical cases; one per configuration), omit Step 2 and process trace one deviant case for the entire solution (Step 3) (Williams and Gemperle 2017: 133). As the main aim of this Chapter is to unravel the deviant cases for coverage, this shorter CPT frame is used here.

4. According to the principle of unique membership, it is necessary to differentiate between the causal effect of the different configurations, and therefore to study cases which are members of only one configuration in order to disentangle which "dynamics are case-specific manifestations of more generalisable processes which should be present across all positive typical cases, and which dynamics are idiosyncracies of the case itself" (Williams and Gemperle 2017: 125-131). If no unique case exists, a joint case can be taken, although the analysis one should differentiate the causal processes between the configurations that the case is a member of" (Williams and Gemperle 2017: 129-131).

5. Schneider and Rohlfing's formula to calculate the most (unique) typical case is

$$
\mathrm{S}_{\mathrm{Ti}}=\frac{\mathrm{Y}_{\mathrm{i}}-\mathrm{X}_{\mathrm{i}}}{\mathrm{X}_{\mathrm{i}}}
$$

$\mathrm{Xi}$ is the numerator which measures the Euclidean distance of the case to the secondary diagonal. The smaller the difference in the membership in $\mathrm{Y}$ and $\mathrm{X}$, the closer the case is to the secondary diagonal and the more appropriate it becomes for process tracing. The formula to calculate the (most) deviant case coverage SDcovi is identical to the formula for the best typical case, but X now represents membership in the truth table row. The 'ideal' case is located in the upper right corner (Schneider and Rohlfing 2016).

6. "The ideal comparison of a typical case and a deviant case for consistency includes two cases that display the maximum membership in the term $X$, the subset in analyses of sufficiency, and the maximum difference between the memberships in the outcome $Y$, the superset" (Schneider and Rohlfing 2013: 588).

7. Schneider and Rohlfing advise to study the truth table row to which the deviant case coverage belongs: it can be interpreted as the sufficient configuration producing the outcome in this type of case. The reason that this truth table row configuration is not part of the solution terms, is that its consistency is below the consistency threshold. Either there are other cases in this row, or the scores of other cases in this row are inconsistent with the pattern of sufficiency.

8. Cf. "the goal of case selection following the unique membership principle is to establish a symmetric relation between an INUS condition and the outcome. As a consequence of this, establishing a difference on the INUS condition is expected to make a difference to the outcome." The analysis of typical cases enables collecting within-case evidence (substantiating the OCA-based inference) that a single condition is an INUS condition, and the conjunction to which it belongs, sufficient for the outcome. Moreover, it enables to infer whether an (additional) mechanism is causal, i.e. to assess whether the presence and absence of the mechanism makes a difference to the presence of the outcome: would the outcome be absent if the sufficient term were present, but the mechanism absent? (Schneider and Rohlfing 2016: 535-38).

9. Following Schneider and Rohlfing's formula to calculate the ideal unique typical case for each solution term, we can use the SetMethods package in $\mathrm{R}$. 
10. "The ideal deviant case coverage cannot be properly located in an XY plot that visualizes a term from the QCA solution. The reason is that this type of case must be selected with regard to the truth table row to which it belongs. Because of the different point of reference, we need to construct separate $\mathrm{XY}$ plots for each truth table row that contains at least two deviant cases coverage" (Schneider and Rohlfing 2016: 549).

11. ${ }^{11}$ World Bank data:

\begin{tabular}{|c|c|c|c|c|c|c|c|c|c|c|c|c|}
\hline & \multicolumn{6}{|c|}{ Economic growth (\% of real GDP) } & \multicolumn{6}{|c|}{ Unemployment (\% of labour force) } \\
\hline & 2004 & 2005 & 2006 & 2007 & 2008 & 2009 & 2004 & 2005 & 2006 & 2007 & 2008 & 2009 \\
\hline Ireland & 4.41 & 6.33 & 6.31 & 5.54 & -2.16 & -5.64 & 4.5 & 4.3 & 4.4 & 4.6 & 6.0 & 12.0 \\
\hline France & 2.79 & 1.61 & 2.37 & 2.36 & 0.2 & -2.94 & 9.2 & 8.9 & 8.8 & 8.0 & 7.4 & 9.1 \\
\hline
\end{tabular}




\section{How do governments deal with inconvenient EU referendum outcomes?}

"To enforce the results of a referendum, especially if it contradicts the position of established authorities, there must be a devotion to democracy and democratic principles that may be lacking. Referendums, as a truly democratic device, work best with leaders in a knife-edge situation where they have enough authority to carry out and respond to the results of the referendum but not so much authority that they can disdain inconvenient outcomes or, in extreme cases, determine the outcome" (Brady and Kaplan 1994: 175).

Since the shift from permissive consensus to constraining dissensus after the Maastricht Treaty of 1992, EU policies and treaties have been increasingly rejected in referendums. 15 out of 61 EU-related referendums between 1972 and 2016 resulted in such government defeat 5 of these referendums dealt with the ratification of comprehensive EU treaty reform, 4 with EU or EEA membership, and 6 with specific policy issues. The rejections of these policies do not only question the legitimate authority of the EU, but also that of their elected national representatives (Rose 2018). Failed referendum outcomes are usually thoroughly analysed to reconstruct 'what went wrong', what determined voting behaviour and what could be improved in future referendums. However, it is hardly analysed what happened after these blunders. The Venice Commission (an advisory body of experts of the Council of Europe on constitutional law) argued that electors must be informed of the impact of their votes and thus the effects of the referendum (Morel 2018a). How irreversible is the referendum decision, is there a winner-take-all logic which may generate frustration of the losing minority? This has to do with the perception of the referendum result among the various actors, their preferences and opportunities. This chapter addresses the question how governments deal with inconvenient EU-related referendum outcomes. Table 6.1 lists the subjects of each failed referendum and the nine countries in which they took place. 
Table 6.1. Defeated referendums on European integration 1972-2016.

\begin{tabular}{|c|c|c|c|c|c|c|c|}
\hline Year & Country & Case & Subject & Type & Turnout \% & Yes \% & No $\%$ \\
\hline 1972 & Norway & NOR1972 & EC Membership & Membership & 79.2 & 46.5 & 53.5 \\
\hline 1992 & Switzerland & SWI1992 & EEA Accession & Membership & 78 & 49.7 & 50.3 \\
\hline $1 r^{-2}$ & Denmark & DEN1992 & Maastricht Treaty & Treaty & 83.1 & $49 \cdot 3$ & 50.7 \\
\hline 1994 & Norway & NOR1994 & EU Membership & Membership & 89 & 47.7 & 52.3 \\
\hline 2000 & Denmark & DEN2OOO & EMU Membership & Policy & 88 & 46.9 & 53.1 \\
\hline 2001 & Ireland & IRL2001 & Nice Treaty & Treaty & 35 & 46.1 & 53.9 \\
\hline 2003 & Sweden & SWE2OO3 & EMU Membership & Policy & 83 & 42.0 & 58.0 \\
\hline 2005 & France & FRA2005 & $\begin{array}{l}\text { Constitutional } \\
\text { Treaty }\end{array}$ & Treaty & 69 & $45 \cdot 3$ & 54.7 \\
\hline 2005 & Netherlands & NET2005 & $\begin{array}{l}\text { Constitutional } \\
\text { Treaty }\end{array}$ & Treaty & 63 & 38.2 & 61.8 \\
\hline 2008 & Ireland & IRL2008 & Lisbon Treaty & Treaty & 53 & 46.6 & 53.4 \\
\hline 2014 & Switzerland & SWI2O14 & $\begin{array}{l}\text { 'Against mass } \\
\text { migration' }\end{array}$ & Policy & 56.6 & 49.7 & 50.3 \\
\hline 2015 & Denmark & DEN2O15 & Opt-in JHA, Europol & Policy & 72 & 46.9 & 53.1 \\
\hline 2016 & Great Britain & GBR2016 & EU Membership & Membership & 72.1 & 48.1 & 51.9 \\
\hline 2016 & Netherlands & NET2O16 & $\begin{array}{l}\text { EU-Ukraine } \\
\text { association treaty }\end{array}$ & Policy & 32.3 & 38.5 & 61.5 \\
\hline 2016 & Hungary & HUN2O16 & $\begin{array}{l}\text { Resettlement mi- } \\
\text { grant quota }\end{array}$ & Policy & 40.4 & $98.3^{*}$ & 1.7 \\
\hline
\end{tabular}

*Officially invalid result: turnout quorum was not reached.

How these countries deal with the No votes and why? Did the government serve the European institutions within which it has endorsed the rejected policy, or did the government serve the majority of domestic voters? The policy outcome is not decided by the national referendum but by the dynamic interaction between the domestic and European actors afterwards (Rose 2018). The government could accept its defeat or look creatively for alternative options in order to improve its losing position. They still have a strategic advantage in terms of the timing of the referendum and the interpretation of the available options when the proposal is rejected (Hobolt 2006: 158). Given the recent defeats, the government has an increasing interest in avoiding the risk of a future defeat or in reducing the political costs of a failed referendum campaign. Hence, they try to limit to limit the reputational loss after a failed campaign while at the same time they are still committed to the EU referendum issue, but quietly try to diverse public attention from the European question to other issues (Schneider 2018: 420). The final government strategy does thus not just reflect its own preferences, but may also be constrained by pressure from other powerful elites, such as from the domestic opposition or from the EU's institutions and other member states in Brussels.

The chapter is structured as follows. First, several possible strategies are designed 
how governments can deal with the defeat. Second, the factors explaining the government's strategy are modelled in terms of preferences and constraints. Then in the main part, case studies of the 15 failed referendums analyse the position of the domestic political establishment and the European political establishment based on the model. Finally, the conclusion unfolds what strategic patterns emerge across similar cases and what this could mean for future inconvenient referendum outcomes. The scope of this chapter is limited to the actor behaviour after these referendums. Therefore, evaluating (what happened during) negotiation processes or the campaigns before the vote is not the purpose, unless elements have (had) considerable impact on the actor behaviour after the vote.

\subsection{Design: how preferences and constraints shape strategies}

\subsubsection{What can governments do after defeat?}

It can be argued that the strategy pursued by elites in order to mitigate the risks arising from the defeated EU-related referendum has four forms: acceptance of the result on the one hand, and ignorance of the result on the other hand. In between two more moderate options are presented: to interpret the result and to circumvent the result by a second referendum. Hence, two paths aim to respect the result, looking for more flexible integration, whereas two other strategies rather neglect it.

First, a strategy to accept the outcome is followed if the defeat allows the domestic and European political actors to maintain the status quo and if this does not bring along severe political consequences for the country itself or for the EU. In fact there is no other option but to accept, because there is no room for alternative interpretation, or to circumvent or neglect the result. This implies that there is no imminent pressure exerted by the EU or the domestic parties to change the outcome of the referendum. Instead, those parties do not want to risk to be punished during the next elections for ignoring 'the will of the people'. In the meantime recourse could be taken to alternative or new policy proposals. Part of this strategy could be to strike a similar deal by which a second referendum is consciously avoided.

Second, a strategy to interpret the outcome is necessary, when the effects of the referendum result are unclear. The interpretation can be shaped by (inter)national compromises in the spirit of the popular result. On the one hand, maintaining the status quo is not an option from a legal or political perspective for instance because the referendum outcome is (considered politically) binding. On the other hand, a direct and straightforward implementation of the outcome could cause practical problems or even serious consequences not only for the country itself, but also for its European partners. Hence, there may be pressure from the European or domestic actors to change the outcome, but in fact there are limited possibilities to do so. 
Third, a strategy to circumvent the outcome is followed in case the European counterparts are extremely dissatisfied with the result and therefore prefer to exert imminent pressure on the domestic government in order to solve its ratification problems. If the referendum is binding and mandatory, an inconvenient outcome can only be 'repaired' by a second referendum, if applicable combined with additional protocols or declarations.

Without, the decision-making process could be derailed completely if the rigid 'unanimity rule' for such treaty ratification applies. If then the domestic government is still in favour of the rejected treaty and experiences sufficient domestic political support for continuing the ratification process, renegotiations of the treaty could be taken up with the prospect of holding a second referendum. Such renegotiations should sufficiently address the country's perceived concerns on the issue and could lead to a modest modification of the treaty itself or its attached protocols, declarations and decisions. In this way, the failed referendum could provide potential additional renegotiation gains for the incumbent government regarding these concerns vis-à-vis their European counterparts, particularly when facing a Eurosceptic electorate which threatens to reject the second referendum too (Hug and Schulz 2005). Moreover, by making a 'take-it-or-leave-it proposal', the government can make voters to accept an unattractive proposal, because the policy resulting from another rejection appears even worse (Hobolt 2006: 158).

Fourth, the strategy to completely neglect the referendum outcome can be deployed, if there is no domestic or external pressure to take the result seriously. Instead, there may be pressure to neglect it. Ignoring the outcome is possible because it does not bring along serious consequences: the referendum is not binding, it does not halt the ratification process, or it does not threaten the government to be ousted from office or to lose the next elections. This implies that the referendum does not pose an additional constraints for the government, domestic parties or European partners to continue to follow their policy preferences. The status quo can be maintained.

\subsubsection{What make governments do what they did?}

Given these actors' preferences and constraints, what avenues could be explored to end up at a particular strategy dealing with the inconvenient referendum outcome? The choice for each strategy can be explained by analysing the preferences and constraints at the actor level and at the structural level. Preferences indicate what the different actors really want to achieve after the failed referendum, while constraints indicate the factors that limit the feasibility of these preferences. The three main actors to be considered are the government, the domestic parties and the European counterparts in Brussels, while constraints could exist at the domestic level, at the EU level and in the serious consequences of the 'No' vote. Moreover, the type of referendum matters in terms of the impact of the preferences and constraints on the chosen strategy.

The first -domestic- constraints contain issues e.g. whether the referendum result 
is binding and/or whether the referendum was mandatory on the issue concerned in order to be ratified or implemented. If a vote is only advisory and it remains the parliament's responsibility to ratify the policy proposal, parliament may be re-involved and intervene downstream to have the final say or hold a new referendum on the same text or a modified version reflecting the views expressed during the campaign (Morel 2018a: 156). Moreover, diverging preferences of the domestic parties may exert pressure on the government (not) to accept the referendum result.

A second constraint is if the diverging preferences of EU partners serve as pressure on the government to ratify the rejected proposal anyway. This constraint is driven by the 'unanimity rule', i.e. all member states have to ratify the agreement. Both the government and the EU institutions are subject to political pressures from the other member states where no referendum has been held. This pressuring response to ask a member state to try again seems inherent to the use of the instrument: the rejection was the result of a referendum, not of a parliamentary vote. On the one hand, during the policy-making process the elected politicians have been involved on an equal footing with political actors from other member states: all treaty revisions are subject to a common accord within the European Council and a popular vote in one member state has no higher authority than parliamentary ratification in another. This has been characteristic for the EU's evolution as a consensus-based, densely integrated political and legal system. On the other hand, in case of a ratification by referendum the electorate only takes part after conclusion of the agreement. The mistrust of the referendum as ratification mechanism by other member states may have translated in unwillingness to accept the inconvenient outcome as decisive (De Búrca 2011: 1478-86). The unanimity requirement for comprehensive treaty reform seems to remain as a constraining mechanism on the way of the EU's future development.

Pressure is therefore a factor which can be used by European partners to pursue their preferences, while it can be perceived by the domestic actors to act in a certain direction. The EU political response to a popular No vote could be to investigate whether the objections underlying the No vote could be accommodated within the terms of the new treaty, without rejecting the entire text and preventing its coming into force for the other member states. The pressure is also constrained by the space to manoeuvre on the issue: is there any room for reinterpretation, renegotiation or opt-outs? Can the government mobilize its coalition parties, sufficient parts of the opposition, and European counterparts to follow its line in order to obtain or maintain the required majority? Are these partners willing to compromise? How much pressure is there to accept the result, or rather to change it, e.g. by means of a second referendum? Is it appropriate to deviate from the referendum result, even if it is legally possible and politically supported? Or will this be perceived as 'political suicide' for the government if the next elections are looming?

A third constraint therefore deals with the consequences of the No for the country concerned, for the government itself and for other European countries. Will the country become isolated from its European partners if the No sustains? The EU could confront the national government with unwanted consequences of implementing a referendum result 
straight ahead. Will the country miss e.g. European subsidies or will it be excluded from market access? If these consequences do not fit with the government's preferences, the government will probably seek to repair these by alternative means. And what if the consequences of a (second) No will put the EU membership of the country at stake? Particularly if the head of government has linked his or her personal fate as an elected politician to the anticipated outcome, a defeat may plunge the government into crisis and force it to resign.

Moreover, the consequences of the No for the European partners have to be taken into account. Will it just have unilateral consequences, for instance that a country does not participate in the single currency? Then the other countries can do little more than accepting the result and retaining the status quo. However, the consequences are far reaching, if the No implies that a multilateral treaty cannot enter into force and in fact blocks the integration process for all other member states or creates a legal vacuum. If this blockade sustains under the 'unanimity rule', the partial failure of the ratification process becomes a total failure. The referendum result could also have domino effects on ratification processes in other member states. These are dramatic scenarios for the European integration process, which the EU cannot ignore.

Finally, the type of referendum (membership, treaty or policy) is considered to have a moderating impact on this strategy too, because the consequences of a rejection of a comprehensive treaty reform are deemed much larger for the other member states, than e.g. the opt-out from the Eurozone.

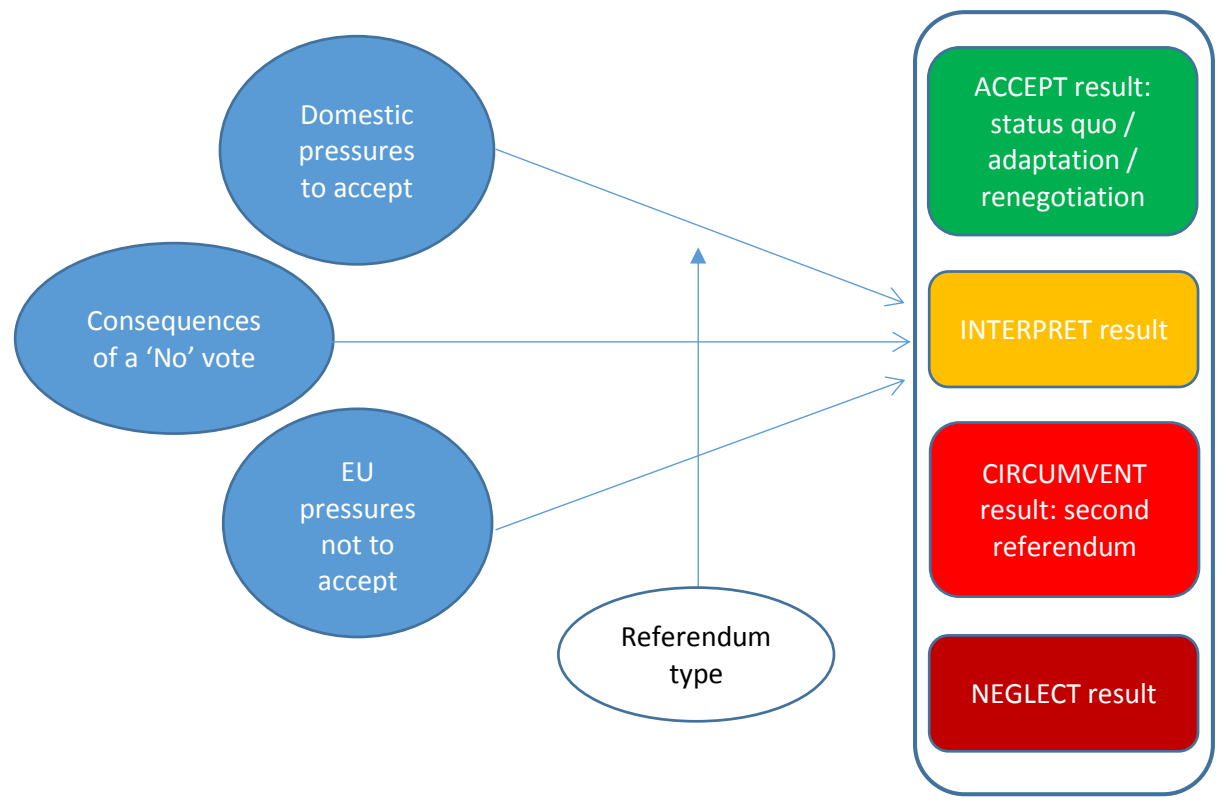

Figure 6.1. Government strategies dealing with inconvenient referendum outcomes. 
Figure 6.1 displays how the options of the country concerned are constrained by the consequences and the preferences and pressure of other domestic and EU political actors to accept the outcome or not. The referendum type mediates the impact of those factors on the chosen strategy. On the right side the model gives an overview how the sum of preferences minus constraints leads to a government strategy, tending towards rather accepting the referendum result on the upper-right side, or neglecting the result on the lower-right side. Having outlined the theoretical considerations for each strategy, the next section explores for each of the 15 failed referendums what strategy was followed and why. The preferences and constraints of the government are benchmarked to those of the other actors in comparable situations.

\subsection{Accepting the result: 'the people have spoken'}

\subsubsection{Adaptation after failed membership}

Failed membership referendums are rather stand-alone issues. The domestic actors' preferences are less constrained by those from their European counterparts, compared to Treaty referendums. There is no large multilateral ratification process at stake and the membership issue has merely consequences for the involved country itself. The verdict is regarded as politically final, and also binds those voters and politicians who had favoured membership. Even when not legally binding, elected representatives often implement the inconvenient result because they attribute larger legitimacy to the referendum result than to their own opinions (Rose 2018: 4). Hence, there is less (time) pressure from European partners to resolve the issue. It is up to the country to make up its mind after the No vote and to figure out how to move on: maintaining the status quo, looking for an alternative relationship with the EU or for another referendum on the same issue after some time. This puts the domestic actors in a relatively autonomous position. The three referendums illustrating how countries adapt to such stand-alone position deal with Swiss EEA membership (1992) and Norwegian EU membership (1972 and 1994).

The Swiss membership referendum on the EEA (1992) was not strictly required. The EEA Agreement and the establishment of several EFTA bodies ${ }^{32}$ concerned a joint decision by the Swiss assembly, which did not require a referendum. ${ }^{33}$ In essence though the referendum outcome was considered politically binding. The EEA provided full access to the internal market without granting the EEA countries to take part at the EU's decision-making table. For many Swiss voters, however, the EEA was perceived as a stepping stone on the way to membership of the EU. The Swiss federal government triggered this perception when it suddenly submitted an application for EU membership in spring 1992. But EEA membership already proved to be a bridge too far: the proposal was narrowly rejected by 50.3 percent of the voters, but also by 16 out of the 23 cantons (Massüger and Kuoni 2011: 135-36). After this 
fallout, no major political force called for the resignation of the responsible ministers or the collective government. The government remained in office, arguing that it was best equipped to figure out the Swiss integrationist policies outside the EEA framework.

From the Brussels' perspective there was no alternative than to accept the Swiss result on the EEA agreement. Switzerland would not become part of the EEA. The EFTA members announced that they would continue the foundation of the EEA without Switzerland. The only left-over Brussels could solve was to enable that Liechtenstein's EEA accession was no longer dependent on Swiss EEA accession. Although Liechtenstein voted to join the EEA in 1992, the decoupling process of separate agreements took until 1995, when Liechtenstein voted again in favour of joining the EEA. Hence, while accepting and respecting the outcome and taking time, the Swiss government found an alternative way to preserve its interests and long-term relationship with the EU. Instead, over the next years, it followed the 'bilateral way', eventually leading to the 'Bilateral Agreements' with the EU which were approved by a referendum in 2000. In this way, the Swiss political establishment demonstrated their creative adaptation to the result. The 1992 EU membership application remained dormant for 24 years, until spring 2016 when the Swiss parliament adopted a motion to give formal notice to Brussels to have the application withdrawn.

The first 'No' to European integration took place in the Norwegian accession referendum to the EC in 1972. The referendum was called to mask the internal divisions within the Labour party. Although not legally binding, the government could have bypassed it only theoretically. Moreover, the Norwegian Constitution requires a three-quarters majority of the Storting to support the transfer of powers to an international organization. It was very doubtful whether this majority would have been obtained in 1972 (Bogdanor 1994: 74). The rejection caused one of the largest political upheavals in Norway, considerable embarrassment and turmoil in the government, making the cadre of the Labour party to leave. The Bratelli-cabinet resigned, finalising a longer process of losing political influence, and was replaced by a centreright minority coalition. The new government had just a mandate to negotiate an industrial free trade agreement with the EC, which came into force in July 1973. The EFTA countries ${ }^{34}$ were linked to the EC by free trade agreements. After the 1972 vote, the Norwegian relations with the EC were run on a non-partisan basis. Government and coalition party leaders felt that the No vote was strongly binding upon them, making the EC membership issue a taboo over the 1970s (Szabó 2006: 283). Instead of EC membership, in 1979 the Storting agreed that Norway should extend its cooperation with the EC by regular, formal meetings with the Commission and the Council of Ministers (Archer 2005: 49-50). The Norwegian economy was in full swing partially due to the discovered oil in the North Sea (Szabó 2006: 275). By the 1980s, however, the position of EFTA was fading away as its members were on their way to the EU. When the EC was enlarged by Greece, Portugal and Spain and expanding its integration towards European Political Cooperation, Norway's geographical security position as a NATO member became more important. "With its dependence on the oil sector of the economy and with the liberalization of its credit market, Norway's domestic economic policies were becoming increasingly dependent on the international situation" (Archer 2005: 52). The passage of the 
Single European Act encouraged a revitalization of the EC that the EFTA countries could not ignore. They started to negotiate to establish the European Economic Area (EEA) (Nelsen 1991). An attempt to have a referendum on the EEA agreement of 1992 was voted down by Labour and the Conservatives, however. In the end the government secured the necessary three-quarters majority in the Storting.

Despite the benefits of EEA membership, it also implied a loss of autonomy on a range of key market matters. EEA membership meant implementing a lot of market regulation without being able to decide upon them in Brussels. This provided an opportunity for the Labour government to revive its goal of Norwegian full EC membership. Things sped up unexpectedly in 1991, when the Swedish government, followed by the Finnish government, submitted their EC membership applications. Norwegian Prime Minister Harlem Brundtland hence announced that the government had decided to apply for membership as well. Nevertheless, the parliamentary support this time was not likely to exceed the required three-quarters majority in the Storting. A second, successful, referendum was therefore indispensable in order to convince the necessary parliamentary majority.

However in 1994, again a small majority of 52 percent of Norwegian voters rejected membership. The desire for independence and national sovereignty proved stronger than the fear of political isolation. This time Labour was able to preserve both party unity and governmental power, despite its internal divisions. The government was disappointed but did not resign. Norway would continue its close cooperation with the EU (Jenssen et al.1998). Being already a member of the EEA, there was no need to negotiate a supplementary treaty with the enlarged EU (Archer 2005: 57-8, Gallagher and Uleri 1996: 149-50). After 1994 the membership issue was removed from the political agenda. Instead, Norway has followed a line of active EU-adaptation. The coalitions formulated so-called 'suicide- clauses' (if a party in a coalition government launches a campaign for EU membership, the coalition unravels). At the same time, Norway became almost as integrated in the EU as any member state (Fossum 2009: 2). As Norway's most trade and business is with the EU, to secure market access was of vital economic concern. By means of the EEA thousands of legal provisions have been incorporated into Norwegian law since 1994. The dynamic structure of the EEA agreement and Norway's incorporation in the EU in the other pillars made it easier to decouple EU adaptation from membership. Norway is part of the Schengen Agreement, has cooperation agreements with Europol and Eurojust, and takes part in the EU's civilian and military crisis management. The shutdown debate on EU membership and the ongoing process of adaptation renders Norway rather more than less subservient to the EU (Fossum 2009). The three cases demonstrate that there was neither domestic pressure necessary to accept the result nor European pressure not to accept it. Staying outside the EC, EU or EEA did not have serious consequences for the EU. It was evident that the government would respect the referendum result. 


\subsubsection{Renegotiation after the failed Constitutional Treaty}

The rejection of the Constitutional Treaty in France and The Netherlands in 2005 caused a 'total failure' of the ratification process. Two founding member states blocking the ratification process was too much for the European Constitution. How was dealt with these major blows of EU decision making? The French No was the first major member state rejecting a comprehensive treaty reform. The French result put the Dutch government immediately in a more defensive position, because the Dutch referendum was scheduled only three days later. The result was at least as devastating: a large majority of 61.5 percent of the Dutch voters massively rejected the Constitutional Treaty with an unexpectedly high turnout of 62 percent. This displayed an enormous gap emerged between the electorate's opinion and their representative elites, who had supported the CT in the Second Chamber by an 85 percent majority of 128 out of 150 seats (Aarts and Van der Kolk 2006). A comparable gap between the representatives and the citizens emerged in France. In contrast, in Spain and Luxembourg it had been merely the supporters of the government parties that sealed the successful outcomes (Crum 2007: 76). This time, the referendum results were framed as a European problem. This paved the way for renegotiation of the complete treaty, as had already been suggested by the campaign of the No camp. The Socialist Party rejected a re-ratification. The PS instead proposed a new, strictly institutional treaty, to be ratified by referendum. Chirac also followed this line, by demanding that the reform of the EU was based on the existing treaties. Interior minister and would-be presidential candidate Sarkozy continued the strategy in 2006 (Closa 2013: 157-8).

The main consequence of the French No was the resignation of Prime Minister Raffarin. President Chirac appointed Foreign Minister De Villepin as new Prime Minister and Nicolas Sarkozy as new Interior Minister. The new government was composed in such a way that it aimed to show that Chirac was taking account of the citizens' concerns (Ysmal 2006: 1106-9). Socialists emphasised the loss of Chirac's political legitimacy, who had initially hinted on the referendum in order to strengthen his power. The political elite claimed that the vote was not against the EU but rather against specific policies which were 'too liberal and market oriented, or too statist' (Morel 2018a: 160).

Where in France Chirac was blamed for the failure, in the Netherlands the political elite carefully avoided any blame. It was notably the Dutch parliament itself who had initiated the consultative referendum. As a consequence of the No, the Dutch government withdrew the ratification bill of the Draft Constitution. Despite of the consultative nature of the referendum, in practice a consensus progressively emerged amongst almost all of the main political parties that the result would be respected. When the discussion in Brussels on the CT calmed down, so did the saliency of the issue in the Dutch public opinion.

In the rest of Europe, diverging reactions emerged. The Danish prime minister Rasmussen quickly voiced that the No's should be respected: as long as France and the Netherlands do not ratify the Constitutional Treaty, it is shelved. The major blow initiated a sequence of anti-ratification movements. Compared to the other three treaty referendums, 
this time there was less pressure to continue the ratification process. Rather a discussion started whether or not to renegotiate. Politicians initially reacted with disbelief and denial. Several other referendums had been scheduled. But what could these referendums bring? Either the likely risk of a probable defeat, or the insignificance of a win given the halted ratification in other states (Closa 2013: 152-4). As a result, apart from the Luxembourg referendum on the $\mathrm{CT}$ which was scheduled in July, the other expected referendums in the Czech Republic, Denmark, Poland, Portugal, Ireland and the UK were shelved. Prime Minister Blair, who had given in to hold a referendum, decided to postpone it indefinitely only days after the French and Dutch No. While Blair's colleagues Juncker, Schröder and Chirac urged him to refrain from proclaiming the treaty dead, the British pre-emptive action encouraged other countries to untie domestic referendum commitments and halt ratification, such as the Czech Republic (Closa 2013: 161).

The June 2005 European Council recognised the difficulties in two member states, but did not question the "validity of continuing with the ratification processes." The ratification timetable would be altered "if necessary in response to these developments and according to the circumstances in these member states" (Council 2005). The European Council initiated a reflection period of a year, which should be used for a broad debate on European policies: 'Plan-D' (referring to dialogue and discussion). This made other member states realise that the CT was indeed 'dead'. Nevertheless, the German government considered the ratification process just interrupted. While some other member states such as Finland still ratified the CT, this did not advance prospects of ratification in other countries. The Luxembourg government claimed that all countries should be equally treated, irrespective of their size in relation either to the value of their respective ratifications, while the Danish government stated that neither large (nor small) countries unilaterally might stop ratification. The implied but not expressed argument was that France and the Netherlands should vote a second time, like Denmark and Ireland had done in the past. Luxembourg's Prime Minister Juncker announced that his country would proceed with its referendum and threatened to resign if the people rejected the Constitution. But they supported it and Juncker remained in office.

In January 2007, the pro-ratification countries met as so-called 'Friends of the Constitution' and considered it unacceptable that the [qualified] majority of countries which had ratified be held hostage by those states unwilling to ratify. 35 German Chancellor Angela Merkel observed that 18 of the then 27 member states had ratified the EU Constitution. She wanted to revive it. By the end of 2006, the Commission, the EP and even the staunchest government supporters of the CT (Spain and Germany) became convinced that renegotiation was a necessity. The rotating German EU Presidency took the task of holding in-depth consultations with the member states and then submitting a report to the Council. The solution to the impasse came in spring 2007, after a new round of institutional negotiations, with a Solemn Declaration commemorating the $50^{\text {th }}$ anniversary of the Rome Treaties (Closa 2013: 155-7). The strategy was to accept the rejection of the CT, but also to avoid ${ }^{36}$ new referendums on what would eventually become the Lisbon Treaty. Policymakers sought to depoliticise the substance of the treaty by removing symbols and modifying 'statehood' like 
clauses which could provoke national referendums. In case of Denmark, the treaty framers modified 11 clauses, so the Danish Ministry of Justice could conclude that Denmark was not constitutionally required to hold a referendum (Rose 2018: 14).

Shortly after the referendum, the Dutch government became the staunchest defender of the view that 'the Constitution is dead', emphasised by the statement 'No means No'. But still by the end of 2006 it argued that time had not yet come for substantive conclusions about possible treaty revisions given the fact that the member states were deeply divided. Meanwhile, the opposing Labour Party stated in its manifesto that a referendum on a new (constitutional) treaty was necessary (PvdA 2006: 103). After the elections of 2006, the Labour Party ended up in government, but did not enforce a second referendum. Particularly the largest coalition party CDA of incumbent Prime Minister Balkenende wanted to avoid a second referendum, and was supported by its coalition partner ChristenUnie.

The German EU Presidency was determined to reach a compromise on a new reform treaty during the first half of 2007. The Dutch 2007 coalition agreement settled for a revision of existing treaties, which should be different in scope and name than the $\mathrm{CT}$. As a consequence, the new Dutch government had to take a position whether it aimed for a referendum or not on such a new treaty. The coalition parties eventually left the question whether or not a referendum ought to be called to the Council of State. This advisory body of the government should assess whether the new EU treaty contained 'constitutional' elements, like the CT (Dutch-Coalition-agreement 2007: 3, 13). A remarkable change was the position of the pro-European parties who expressed the concerns voiced by the No parties, e.g. 'no European super-state'. The new Dutch cabinet strived for a modification of existing treaties which should 'convincingly differ from the previously rejected CT in substance, size and name'. Prime minister Balkenende wanted to address concerns such as a loss of national sovereignty and the pace at which integration -notably the EU's recent enlargement processhad taken place. Fewer rules, concrete results (on security, economic growth, energy, antiterrorism) and getting Europe closer to its citizens, that was the new message. On top of that, the Dutch government demanded a lower net contribution to the EU budget, when the multiannual financial framework was discussed (Closa 2013: 158-9).

The Council of State concluded that 'unlike the Treaty establishing a Constitution for Europe,' the draft reform treaty 'provides no arguments for a gradual expansion of the EU towards a more explicit state or federation' (Rood et al. 2008: 47). It referred to the draft IGC mandate of the European Council of 21-23 June 2007, which had abandoned the constitutional concept. ${ }^{37}$ The Council of State considered that the ordinary ratification procedure should not be supplemented with a plebiscite (Dutch-Council-of-State 2007). Subsequently the Dutch cabinet shared the Council of State's opinion that the treaty distinguishes itself distinctly from the CT, considering it did not contain content or symbols towards a state or federal direction (Dutch Dutch-Government 2007). Since the coalition parties CDA, CU and (reluctantly) PvdA, but also opposition party VVD considered that a plebiscite was not necessary, the proponents of another referendum (SP, PVV, PvdD, GroenLinks and D66) did not comprise a parliamentary majority to enforce a referendum. Hence, the Lisbon Treaty was ratified in parliament by 
a simple majority (EuropaNu n.d.). In France, the newly elected president Sarkozy simply managed to ratify the treaty in parliament without holding a referendum. The solution of the ratification deadlock of the $\mathrm{CT}$ by renegotiation was feasible, because the referendum result was (at least considered) binding, and hence there was domestic pressure to accept it, and no (strong) European pressure for additional protocols or a second referendum on the same text.

The ratification of the Lisbon Treaty proved to be a successful recipe for avoiding the risk of a referendum veto by formulating policies that do not require unanimous approval by all member states. The period after the referendums on CEE accession and the CT can be characterised by high levels of elite consensus against recourse to direct democracy instruments. An example of this avoidance is the Fiscal Compact of 2012, which could enter into force after ratification by 11 member states - so even in the event the Irish people had rejected the treaty. However, the threat that Ireland would loss European financial support after the economic crisis from 2008 onwards sufficed for a large majority to endorse the Fiscal Compact in a referendum.

\subsubsection{Status quo after a 'No' to the Euro}

The referendums in Denmark in 2000 and 2015 are the direct consequence of the 1992 National Compromise on the Edinburgh Agreement, stating that the opt-outs Denmark has negotiated, can only be overturned by another referendum. Although the compromise was a political agreement, the referendums on opt-ins on the Euro (2000) and Europol (2015) were also constitutionally required because the five-sixth parliamentary majority (needed due to a transfer of sovereignty) was not met. Being its first 'popular test', the Danish No in 2000 was considered a major blow to the European currency, one year after it was introduced on the markets and two years before its real introduction in 2002. Prime Minister Poul Nyrup Rasmussen (Labour) described the result as a humiliating defeat for Denmark. He had strongly campaigned for a Yes vote, but made clear that he would not resign in case of a No. Rasmussen emphasised that, in spite of the vote, Denmark would continue to play its full part in the future development of the European Community. Finance Minister Mogens Lykketoft added that the country was unlikely to hold another referendum on the Euro for at least five years. He feared that the result would spark a Europe of different speeds. It was expected that the vote would also have an immediate knock-on effect on deliberations to introduce the Euro in Sweden and Britain.

The British government at the time had plans for a referendum on joining the Euro if economic conditions were right, but the Danish referendum was a severe setback for this ambition. European Commission President Prodi regretted but accepted the result. There was no EU pressure for a second referendum this time. However, Brussels feared that the vote could undermine international confidence in the currency as well as EU support in -thenprospective Central and Eastern European member states. Prodi dismissed suggestions of a two-speed Europe and said that Denmark could still join EMU at a later date (Evans-Pritchard 
2000). The member states reacted disappointed and tried to downplay the issue. French Prime Minister Jospin dismissed the Danish economy as 'not a European heavyweight', like Germany's Finance Minister Eichel proclaimed that 'the rest of Europe would survive the vote'. When later on the Danish government published a White Paper 'Denmark in Europe', the currency issue was not even discussed (Miller 2000: 21-22).

Probably inspired by the Danish referendum on the Euro, in Sweden, the governing Social Democratic leadership was forced into granting a referendum in order to secure an EMU-positive resolution at an extraordinary party congress in March 2000. The referendum was partly opted for to circumvent internal divisions and partly to accommodate the small Eurosceptical parties (Sitter 2009: 90). Nevertheless, the Swedish elite was in shock when in 2003 a majority of 58 percent of the Swedish voters rejected to join the single currency. ${ }^{38}$ All major parties, business organisations, newspapers and Stockholm's establishment had favoured the Euro (Persson 2013).

Like in Denmark after its 2000 referendum, the issue of joining the monetary union was put off the political agenda in Sweden, at least for the medium term. Only a significant change in prevailing economic conditions may once put it back there (Aylott 2003). The vote provided clear guidance for political decision-makers. The Yes side declared quite clearly after the vote that Sweden could only introduce the Euro in 2013 at the earliest convenience, after another referendum (Widfeldt 2004: 514). The reactions both in Sweden as well as in Brussels were relatively calm, although the campaign had grieved under the murder of Foreign Minister Anna Lindh -the leader of the Yes campaign- just days before the vote. Brussels was confident that the Swedish Government would 'keep the euro project alive'. Prime Minister Persson said the result was easy to accept because the margin of victory was convincing, the turnout was high, and the issues had been thoroughly debated (BBC 2003). The EMU issue was successfully isolated from the rest of everyday politics and Persson made clear that he would not resign (Aylott 2003: 12).

Without a considerable need or attractiveness to be part of the Eurozone, it will be difficult for politicians to convince a majority of Swedes that they have much to gain by joining the Euro. Since the referendum public opinion polls have shown a continuous majority among the Swedes opposed to join the single currency, particularly since the economic crisis in Greece from 2010 onwards (Statistics Sweden 2010). As politicians do not see large gains either, the issue has remained off the agenda. Although several CEECs have introduced the Euro after their accession to the EU, it seems that the Danish (and Swedish) opt-out has set a precedent framework to join the EU, but stay outside the Eurozone as long as possible or is viable. 


\subsection{Interpreting the result: No means what?}

\subsubsection{UK 2016: 'Brexit means Brexit'?}

The second British referendum on EU membership has caused the largest upheaval in the history of the European integration process. Although initially the polls suggested a moderate majority for the Remain camp, the Leave camp finally won it by 52 percent. This was clearly not what Prime Minister Cameron had aimed for when he announced his plans for a referendum in 2013, attempting to stop Eurosceptic Tory revolts. Although the result was not a legally binding, it was considered politically binding. By renegotiating a reform deal for a new settlement of the UK within the EU, including an 'emergency break' on the free movement of EU nationals to the UK, ${ }^{39}$ Cameron had convinced his cabinet, his 27 European colleagues, a parliamentary majority, but he did not win the required majority of the British voters. The desperately crafted envisaged 'new settlement' between the $27 \mathrm{EU}$ members and the UK of February 2016 ceased to exist, due to a special clause included to do so in case the UK would vote to leave the EU" (European Council 2016b).

The day after the vote, Prime Minister Cameron resigned, triggering a fierceleadership contest within the Conservative Party. Cameron argued that it was up to his successor to trigger Article 50 of the EU Treaty within the next months. Boris Johnson, Michael Gove, Theresa May and some others were in the race to become the next prime minister. However, Johnson announced that he would not run when his Leave ally Michael Gove unveiled his candidacy. After two voting rounds Theresa May was the unopposed leader. As new prime minister she claimed 'Brexit means Brexit', but upon till today it remains unclear what that really means. The Leave camp did not indicate any particular Brexit modality (Morel 2018a: 161). May's government attempted to set its own timeline when and how to trigger Article 50 of the Treaty on the European Union. A major difference with the 1975 referendum was that leaving the EC then would have required some negotiations and which would have had an impact on the UK, but nothing compared to disentangling the UK after more than 40 years of integration and incorporation of the expanding acquis communautaire into domestic law (Smith 2016)

In 2016 the European leaders quickly called the UK to leave as soon as possible. The EU institutions declared that no renegotiation were to be scheduled and urged the UK to act on the vote in order to avoid unnecessarily prolonging uncertainty (Rankin et al. 2016). The UK should not be treated more favourably by threatening to leave and then get a second chance by another referendum. This haste was also inspired by knock-on effects the Brexit vote, leading to intensified Eurosceptic calls for similar exit referendums in countries such as Austria, the Czech Republic, France, Italy and the Netherlands (Oppermann 2018: 248). German Chancellor Merkel expressed "great regret" on Britain's decision, but also said the EU should not draw "quick and simple conclusions" that might create new and deeper divisions.

In autumn 2016 the British government's Brexit policy was challenged at the 
High Court by Gena Miller among others. The issue at stake was whether, "as a matter of UK constitutional law, the Government is entitled to give notice of a decision to leave the European Union under Article 50 by exercise of the Crown's prerogative powers and without reference to Parliament." Neither the 2015 EU Referendum Act nor any other Act of Parliament conferred statutory authority to give such notice. In a first ruling, the High Court held that Parliament must be heard. The 1972 European Communities Act enabling British EC accession was an explicit transfer of sovereignty from the UK to the EC which had been approved by Parliament. It follows that a return of sovereignty by a repeal bill also requires explicit parliamentary consent. The fundamental rule of the UK's parliamentary sovereignty included that the Crown (i.e. the Government) cannot by exercise of prerogative powers override legislation enacted by Parliament. The UK Government contended that triggering Article 50 will have the effect of changing domestic law: elements of EU law which Parliament has made part of domestic law by the 1972 EC Act will 'in due course cease to have effect' (High Court of Justice 2016). This line was upheld by the Supreme Court's ruling in January 2017.

This latter judgement also contained that no constitutional conventions implied any devolved competences for the nations such as Scotland and Northern Ireland to be involved in the Brexit negotiations. This was a matter of British external (foreign) policy. Complicated matter was that a majority in Scotland and Northern Ireland had voted to remain, despite the British majority of voters supported Brexit. Scottish First Minister Sturgeon announced after the referendum that a second Scottish independence referendum 'was on the table' again. She was ready to take all possible steps to secure Scotland's place within the EU. However, the British government so far has rejected calls for another referendum as well as Scotland's blueprint to stay in the single market by participating in the European Economic Area. In spring 2017, Scottish First Minister Sturgeon reiterated calls for a Scottish independence referendum. The SNP election manifesto called for a referendum at the end of the Brexit negotiation process (Taylor 2017).

In December 2016, the House of Commons adopted a motion to support the government's intention to trigger Article 50 by the end of March 2017 (Sparrow 2016). Later on, Prime Minister May had promised that Parliament will get a consensual (take-it-or-leaveit) vote on the final deal (Mason 2017). On 29 March 2017, the British government officially submitted a letter notifying its intention to leave the European Union. The negotiation period started and should be concluded by March 2019. Shortly thereafter, Prime Minister May called for early elections taking place in June 2017 in order to strengthen her mandate for the Brexit negotiations. Instead, the Tories lost their absolute majority and some Tory MPs started to rebel against May for a hard Brexit. May was forced to build a coalition government with passive support of the Northern Irish Unionists (DUP), who had favoured Brexit despite concerns for a return to a hard border between Ireland and Northern Ireland. May's proposal on the Irish border envisaged Northern Ireland to leave the single market and the customs union.

Meanwhile, both Brussels and London struggled on formulating the context of the negotiations. Several scenarios between a 'hard' Brexit (EU-UK relations based on WTO 
rules) or a 'soft' Brexit (up to full membership of the single market and customs union) were outlined. The subservient Norwegian EEA model does not seem very appealing. Prime Minister May voiced the slogan "Better no deal than a bad deal," while the Commission's task force preparing the negotiations issued a Working Paper on 'Essential Principles on Citizens' Rights' (Commission 2017). It called for 'current and future family members' of EU citizens to be protected and that the European Court of Justice should have full jurisdiction corresponding to the duration of this protection in the Withdrawal Agreement (O'Donnell 2017). Keeping the outcome of the 2017 general election in mind and the real negotiations under way, it remains to be seen how the Brexit referendum will eventually be interpreted. By autumn 2017, the main dispute between the UK and the EU-27 concentrated on the UK's financial obligations to the EU to compensate its withdrawal from the EU budget until 2020 (between $€ 20$ and $€ 80$ billion). The UK wants to maintain EU rules in force two years after its exit in 2019 in order to find more time to transpose existing EU law into UK law (BBC 2017). The Article 50 negotiations are likely to take the full two years and possibly a transition period until at least 2021 disentangling the old and constructing the new relationship between the UK and the EU. The handling of the Brexit referendum shows that interpretation of the result is necessary, because on the one hand there is strong pressure in Britain to implement the exit, while on the other hand there are serious consequences, certainly in case no deal can be agreed upon and a hard Brexit is looming.

\subsubsection{The Swiss, Danish and Dutch referendums 2014-2016}

Referendum results do not always produce the expected consequences. In Switzerland "the political class has been skilful in evading awkward referendum decisions" (Butler and Ranney 1994: 260). Swiss direct democracy has been under strain over the last few years due to globalisation and Europeanisation as it now covers a growing set of international treaties. These votes on ratification leave no further manoeuvring room at the national level or to look for compromises that would reflect the domestic power balance (Papadopoulos 2001: 51). After the failed referendum to join the EEA, Switzerland set up a framework of bilateral agreements with the EU (the so-called 'bilateral way'). By means of these seven, tied agreements, Switzerland has preferential access to the European single market. Tied agreements are also referred to as the 'guillotine clause': the termination of a given agreement would automatically lead to the termination of six others. The bilateral way found support among the Swiss people along several referendums over the last decades, although instead of a 'permissive consensus' on European integration, these referendums created a 'constraining dissensus' and contributed to the politicization of EU matters (Sciarini 2017: 174). The Swiss governing People's Party played a 'double game' by using direct democracy initiatives in foreign and immigration policy to oppose the government to which it belongs. At the same time, it was up to the entire government to implement the SVP's successful popular initiatives.

In this way, a small majority of the Swiss supported the SVP's popular initiative 'Against mass immigration', limiting free movement of EU workers, and calling for the 
reintroduction of quotas for immigrants from the EU and changing the Federal Constitution accordingly. The result put tensions between the adopted domestic goal (to control immigration) and a foreign policy goal (to continue the bilateral way). In foreign policy, such a defeat is not just painful for the government and parliament, but also more problematic. According to Sciarini,

"it also affects the negotiation partner(s) with whom the agreement was concluded. In such a situation, restarting a new process if obviously more complicated, since it depends on the willingness of the negotiation partner (...) in foreign policy, a single negative vote may lead to a deadlock from which the Government may then have a hard time to escape. Similar problems arise when a direct democratic vote on a given issue contradicts previous international commitments made by Switzerland in related fields" (Sciarini 2017: 173).

Such problems arose when the 'Against mass immigration' initiative threatened the bilateral agreement on the Free Movement of Persons. The initiative was in full contradiction with the agreement since it aimed to reintroduce control over immigration through quotas on foreign workers, and preference for national workers on the job market. The Swiss government must renegotiate international commitments within three years to put them in line with its requirements (Sciarini 2017: 177). It did, however, neither explicitly aim to a general halt of immigration nor did it demand to end the bilateral agreement with the EU.

The vote had two immediate consequences. First, it jeopardised the bilateral relationship between Switzerland and the EU, especially the Swiss access to the single market (Schneider 2018: 426). The result triggered hostile reactions in Brussels: the EU was not willing to curb free movement rights for its citizens. The EU ruled that implementing the referendum result would abrogate the bilateral agreements that the Swiss government wanted to maintain such as the EU-wide Horizon 2020 research programme and the Erasmus+ exchange programme for students (Swissinfo.ch 2016). The second consequence was that, in reaction, Switzerland suspended the extension of the free movement agreement to Croatia, which had joined the EU in 2013. Subsequent negotiations between the Swiss government and the European Commission proved quite cumbersome. Particularly after the Brexit referendum, Brussels was not willing to give in on something the EU-27 member states had refused to the UK. Hence, the Swiss government climbed down from the initiative's imperative, agreed to dilute its effect, and attempted to implement it without endangering the existing bilateral agreements.

After the government submitted an unusable and illegitimate bill to the Swiss parliament, it was up to Swiss MPs to find a solution before the constitutional implementation period of three years would expire. The compromise they reached in December 2016, called 'Domestic priority light' did not put any curbs on immigration. Instead of quotas it ordered employers to prioritise Swiss residents rather than foreign workers in areas where unemployment rate is above average and it requires foreign workers to demonstrate that they are integrated in Swiss society in order to obtain a residence permit. $4^{\circ}$ Both houses of 
Swiss parliament accepted the compromise. Unsurprisingly the Swiss People's Party voted against the measure and called the plan 'a betrayal of voters' wishes'. When the compromise was adopted, the Swiss government finally extended the agreement on free movement of people to Croatia. The EU had agreed that Switzerland would return to full participation in the Horizon 2020, research programme in 2017 if the Swiss ratified Croatia's participation in the free movement agreement. Commission President Juncker welcomed the Swiss parliament's decision and said it meant a return of bilateral relations to a "situation that can be described as normal" (Swissinfo.ch 2016). It seems that after this referendum repair, Swiss-EU relations have normalised indeed.

The Danish 2015 referendum on the opt-ins on Justice and Home Affairs and Europol had a different impact. Although the Yes parties represented more than 60 percent of the Folketing and were backed by all trade unions and industry organisations, 53 percent of the Danish voters rejected the opt-in proposal on the Area of Freedom, Security and Justice, including direct applicability of acts upon the Schengen acquis. In order to remain distant from the Brexit referendum to be expected in 2016, the new minority government of Prime Minister Lars Løkke Rasmussen announced by mid-2015 that the referendum would take place before the end of that year (Hollander 2016: 285-6). However, the political establishment did not expect the interference of the refugee crisis in autumn 2015. The easy-Yes became a nightmare scenario when the No side on voting day had managed to turn the tide. Instead the No camp proposed -special- parallel agreements with the EU on Europol (Ibolya 2015).

The Edinburgh Agreement of 1992 had established that Denmark participates only in those areas of justice and home affairs managed in an intergovernmental framework, i.e. Denmark would not transfer sovereignty to the EU on these matters. This was no problem, as long as intergovernmental cooperation was the norm in this 'pillar' of EU decision-making. From the Lisbon Treaty onwards, however, the policy area of judicial and criminal cooperation, migration, visas, asylum was supranationalised, and Denmark was left out. As Europol was to become an official EU agency under supranational jurisdiction, Denmark's opt-out threatened it to be pushed out of Europol. As Denmark was one of the largest users of the EIS cross-border crime database, the six parties in the Folketing reached an agreement that they would like to replace the opt-out for an opt-in model, an alternative parallel agreement.

After the No vote, the government initiated talks for a special agreement ('operational arrangements') in order to minimise negative effects of the Danish departure from Europol (Commission 2015). These would not only be endogenous for Denmark, but also exogenous for the remaining Europol members, because no country would benefit from a weak link in police cooperation with Denmark, which still operates within the open border Schengen Area. The deadline to reach an agreement was 1 May 2017, when Europol became a full EU agency. Unexpectedly, by the end of April 2017, both the Danish and European Parliament, as well as the Council approved the Europol deal. It ensures Denmark's (indirect) access to the Europol databases and vice versa (TheLocal.dk 2017). Denmark will also have an observer status in Europol's board meetings, but without voting rights. Moreover, the agreement is conditional upon Denmark's membership of the Schengen area (Maurice 2017). Like the 
Edinburgh Agreement of 1992, this agreement shows the creativity of the EU institutions and member states to deal with complex referendum results.

In the Netherlands a referendum took place in April 2016 on the ratification bill on the EU-Ukraine Association Agreement (AA). The vote was initiated by means of 400,000 signatures, based on the Advisory Referendum Act (ARA) which just had entered into force in 2015. 61 percent of the voters rejected the agreement. The result was valid because the 30 percent turnout threshold was just met by 32.3 percent. At the same time, the vote was not binding, although a majority of parties had indicated that the outcome should be respected in some way. This constrained the Dutch government as it could not be sure that the ratification bill would pass anyway. Prime Minister Rutte made clear that the Dutch government had no intention to ignore the popular opinion and to 'simply ratify' the AA by law. This was not surprising given the potentially damaging ramifications by the elections of March 2017. Although the government had to withdraw or maintain the ratification act as soon as possible, parliament accepted that the matter was postponed until after the Brexit vote on 23 June 2016.

The subsequent European Council of 28 June 2016 urged the Council of the EU to seek a solution to address the concerns expressed in the debate preceding the Dutch referendum as soon as possible. The Dutch government did not stop or push through ratification but sought a third 'legally binding' alternative solution by means of a declaration..$^{41}$ Hence, other member states did not hint at any renegotiation but simply pointed at the advisory nature of the referendum and framed it as a Dutch domestic political problem. Parts of the agreement provisionally had already entered into force. Hence, a possible decision of the Dutch government not to ratify the AA would not have the same far-reaching consequences as did the Dutch No in 2005. However, Given the international pressure and image of the Netherlands, not ratifying was not considered a desirable option for the Dutch government.

Pointing at the geopolitical context of Ukraine, the civil war taking place and influencing pressure to the country from Russia, Prime Minister Rutte urged all political parties 'given the national interest' to look for a solution. The Christian Democrats in the Second Chamber were stubbornly against (despite they had favoured the AA before the referendum), but some of their senators in the First Chamber (needed for a majority) seemed willing to cooperate. Keeping that envisaged majority in both houses in mind, the European Council of December 2016 adopted a 'Decision' on the interpretation of some parts of the AA. This decision is legally binding as a matter of international law on the 28 member States -but not on Ukraine, and may only be repealed unanimously. It would take effect once the Netherlands has ratified the agreement. Otherwise the Decision will cease to exist.42 Although the decision does not change anything to the AA itself, Prime Minister Rutte hoped to convince a majority in both houses of parliament. Indeed, in May 2017 the Dutch Senate finally adopted the Association Agreement.

The first bottom-up referendum experience on an EU matter in a member state had a remarkable epilogue. Shortly after the vote Interior Minister Plasterk announced an 
evaluation of the ARA (implying possible modification or abolition of the turnout quorum). However the new coalition agreement between VVD, CDA, D66, and ChristenUnie, announced in 2017 to repeal the ARA, because it 'has not met expectations' (Dutch-Coalition-agreement 2017). After a fierce debate in parliament and in the public opinion, the small coalition majority in the Second Chamber repealed the Act in February 2018. The Repeal Act included a highly disputed rule that this repeal act could not be subject to an advisory referendum itself, which the Dutch Council of State qualified as legally effective, but politically debatable (Dutch-Council-of-State 2017). If the First Chamber were to keep the Act alive, it may well be triggered for future EU enlargement referendums. The Swiss, Danish and Dutch referendums of the last years show that due to the pressure of some domestic and European not retain the status quo and the serious consequences for the EU, the political actors creatively looked for alternative solutions.

\subsection{Circumventing the result: railroading to a Yes?}

Comprehensive treaty referendums have in common that they can only enter into force if all member states have successfully completed their ratification processes. This is called the rigid unanimity rule. The member states have been skilfully coping with this ratification process in a complex and interdependent institutional framework, as Closa notes:

Governments have "an incentive to manage their domestic ratification processes in a way that makes it easier for other governments and actors to achieve the common goal of successful implementation of a new treaty. Timing is their primary instrument for the strategic management of these processes. Two assumptions lie behind this conclusion: first, national circumstances are, by and large, main conditioners of domestic ratification events; and second, all governments share a similar interest in the outcome (i.e. successful ratification)." (Closa 2013: 167-8).

As the following shows, the Danish referendum on the 1992 Maastricht Treaty, and the Irish referendums on the 2001 Nice Treaty and 2008 Lisbon Treaty are considered 'partial defections', because they could be repaired by a second referendum in the subsequent years.

Government behaviour after treaty referendums is constrained by the preferences of EU actors on the one hand, and by the preferences of a domestic parliamentary majority on the other. All governments realised that maintaining the status quo of the referendum result was not an option. However, if the government took no action the defection of ratification in one country could lead to total failure. The government does not want to be blamed for this total failure and seeks a way out. Since unilateral reservation to (parts of) the treaty or provisional application are not possible (cf. De Búrca 2011), the initial reaction of the government involved is then to renegotiate. 


\subsubsection{Partial defection: a domestic problem}

"We have put ourselves in an extremely difficult situation and we must limit the damage, but I don't see how. As a Danish citizen, I'm shattered." Henning Christopherson, Vice President of the European Commission after the initial rejection of the Maastricht Treaty in 1992 (quoted by Schneider 2018: $420)$.

Of the failed referendums, particularly those on treaty referendums in Ireland were legally mandatory and binding. This is a structural constraint limiting the freedom of manoeuvre for both domestic and European actors to push through their preferences. It gave the government the choice to either accept the result or to look for a second referendum. The Irish referendums on the Nice Treaty and on the Lisbon Treaty were both binding and constitutionally necessary, because the treaty had constitutional implications (i.e. a transfer of sovereignty to the EU). ${ }^{43}$ The Danish referendum on the Maastricht Treaty was also mandatory, because the required five-sixth parliamentary majority to adopt the proposal was not met. The partial defection of these ratification processes persistently met three arguments among the other member states: first, the treaty is not 'dead'; second, no renegotiation is possible; and third, the ratification process must proceed in other member states (Closa 2013). As a result, the negative outcome should be reversed by a second referendum. This argument will reappear in various forms in the discussed cases.

The Danish No to the Maastricht Treaty in 1992 marked the turning point in the process of treaty reforms. It posed the dilemma of how to interpret the effects of one negative result on the ratification process. "The only way out was to frame the situation in which the negative vote could be reinterpreted, and this required the cooperation of both European and domestic actors" (Closa 2013: 113). Danish foreign minister Ellemann-Jensen suggested to renegotiate the day after the vote. This suggestion, however, was immediately dismissed by the Portuguese EC Presidency (Nijenhuis 1992). After the demands for renegotiation seemed inconceivable, "Danish framing turned towards an attempt to reconcile the 'No' vote with the maintenance of ratification and the treaty" (Closa 2013: 115). Hence, the government position should not be regarded in isolation, but is constrained by the position of the parliament and European counterparts. The handling of the Danish case set a precedent for failed subsequent treaty referendums.

Actors throughout the EU immediately framed a discursive reaction to the Danish No containing three lines: 1) the treaty should not be renegotiated; 2) the ratification process must continue; and 3) the ratification process should be accelerated. In the margins of a NATO summit in Oslo in June 1992, the foreign ministers produced a 'crucial' statement, which declared that ratification procedures would continue on the basis of the existing text as scheduled. It excluded any renegotiation. "They agreed that they wished all Member States to participate in the Union, and hence the door should be left open for Denmark [to leave]... The statement framed the situation as a Danish (not an EU) problem" (Closa 2013: 114). As a consequence, the government was pushed to hold a second referendum. 
Likewise in the failed Irish 2001 referendum on the Nice Treaty, European leaders hastened to produce the frames of respect for the results, no renegotiation and maintenance of the ratification processes in other member states. Ireland was the only country to hold a referendum on the Nice Treaty, so the other member states held the Irish responsible for looking for a solution. The result was framed as 'Irish problem'.

Complicated matter was that the Nice Treaty not only should be ratified by all fourteen other member states, but that it also prepared the EU for its envisaged enlargement by Central and Eastern European Countries in the upcoming years. The non-ratification by one member could block the complete accession process. Hence, (EU) proponents of the treaty also framed any possible rejection of the treaty as a 'No' vote to enlargement. This frame 'Nice-equals-enlargement' empowered the voices of applicant states. The European Council in Gothenburg confirmed this, "including willingness to contribute in every possible way to helping the Irish government to find a way forward. It reaffirms its commitment to enlargement and to sustaining the good progress in the accession negotiations." Swedish Foreign Minister Anna Lindh told "the lesson to be learned from this vote was to push ahead with the enlargement negotiations and send a clear message to candidate countries that the vote should not be seen as a rejection to their application for membership" (Closa 2013:125-6). Like with the Danish No to Maastricht, the Irish were told to solve their domestic ratification issues.

In 2008, after the Irish referendum on the Lisbon Treaty, European leaders made equally clear that they respected the outcome, but that renegotiation was not an option, and it was up to the Irish government to find a solution to what was again framed as 'the Irish problem'. By the time of the Irish vote, 15 countries had completed ratification already, and other member states framed the situation in a dramatic one: Ireland could choose between ratifying the treaty or leaving the Union, according to the Irish parliament (Closa 2013: 135). How could these countries and the EU resolve the deadlock if renegotiation was not an option?

\subsubsection{A domestic solution?}

The framing by European partners largely determines how to move on with the situation of a rejected treaty. If framed as a national problem, the member state involved should solve the problem; if framed as a European problem, the EU should solve it. Although all three referendum outcomes prevented the respective treaties to enter into force, three times the remaining member states framed it as Danish or Irish problem, respectively.

The 'Danish' problem on the Maastricht Treaty had a national component (diverging party stances and the popular majority against) and a European one (the other 11 member states favoured the treaty). The strategic behaviour at the European level put pressure on the Danish domestic level to move on. A hectic period full of political reflection and negotiations followed. In autumn 1992 seven parties reached a 'National Compromise' formally called 
'Denmark in Europe'. The formerly opposing Socialist People's Party was one of the creative actors behind formulating the compromise, together with the opposition parties Social Democrats and Social Liberals. They suggested four points, opt-outs, for a legally binding agreement to be negotiated with the other member states:

1. Denmark does not participate in a common European defence policy;

2. Denmark does not participate in the single currency (the third phase of EMU);

3. Denmark will not have obligations connected to EU citizenship;

4. Denmark will not transfer sovereignty in the area of Justice and Home Affairs, but it would participate in intergovernmental cooperation.

In return, Denmark would not prevent other member states from further integration, socalled 'enhanced cooperation' in those areas. If the European Council agreed on those points to be added in an additional declaration to the treaty, a second referendum would be held. This was the first time that a second referendum on the same issue came on the table. In addition, the four opt-outs could only be reversed by means of another referendum (Siune and Svensson 1993: 107-8). The National Compromise should be accepted at the European Council of Edinburgh in December 1992.

Under the British EC Presidency, the agreement was reached that the envisaged opt-outs 'designed to meet Danish concerns' would apply 'exclusively to Denmark and not to other existing or acceding member states'. The opt-outs would take the form of a threefold set of arrangements: one Decision of the European Council, two Declarations of the European Council on social policy and environment, and on defence; and two unilateral Declarations of Denmark on EU Citizenship and on Justice and Home Affairs; all to be associated to the Danish Act of Ratification (European Council 1992). No part of these declarations or decision sought to change existing law or to amend the EU treaties, but rather to offer interpretative reassurance that the concerns on EU citizenship, justice and home affairs, and defence policy were satisfied (De Búrca 2011: 1482). This paved the road for a second referendum on the Maastricht Treaty, combined with the annexed Edinburgh Declaration.

In May 1993 a majority of 57 percent of the Danes voted in favour with a high turnout of 86 percent. The Folketing subsequently approved the Maastricht Treaty by 154 of 179 votes, this time passing the five-sixth majority hurdle. The Edinburgh Agreement had appeased a number of sceptics voting 'No' at the first referendum. Another explanation was that the feeling of insecurity about Denmark's future position in Europe following a second 'No' (Siune and Svensson 1993: 13-15). The repair of the first Danish referendum hence was the consequence of the European pressure to move on, combined with willingness at both domestic and EU level to compromise on additional declarations to be put to a second referendum. This proved to be a useful recipe for future failed treaty referendums. The optouts of the Edinburgh Agreement, secured profound changes on the nature of Danish EU membership that currently greatly limits the discretionary policy of the government on the European integration process. Referendums have served as a means of crafting the DanishEU relationship (Fitzgibbon 2018: 288). 
The Irish 'No' to the Nice Treaty faced the same kind of dilemma for the government. The main question was, how the deadlock of the mandatory and binding referendum could be resolved. Was renegotiation or a second referendum an option? Referring particularly to the Danish National Compromise of Maastricht, the Irish learned "how securing guarantees provided the legal basis to ask the public to vote once again." The Irish even invited Danish politicians to Ireland to discuss the issue. Before a second referendum came on the table, the government "moved to allay electorate fears, securing two declarations on Irish neutrality at the June 2002 Seville European Council summit" (O'Mahony 2009:437).44 They had as purpose to reiterate that the Irish military neutrality was not threatened in any way by the Nice Treaty's Common Foreign and Security Policy (De Búrca 2011: 1483). The second referendum would take place in October 2002. Moreover, this referendum was accompanied by national parliamentary reform, including more informative scrutiny powers on European policies. In this way, the political establishment sought to demine two potentially dangerous issues from the second referendum. First, the Declarations and the constitutional provision should convince 'anti-military EU alliance' voters that the Irish neutrality policy would continue. Second, the vote was decoupled from domestic party politics, limiting the impact of secondorder effects (Garry et al. 2005: 216).

Nevertheless, holding a second referendum on the Nice Treaty was not uncontested. Voices from the No camp wanted the results to be respected ('as valid as any election, re-run is an attack on democracy') "with the well-worn quip that the Irish would simply have to keep voting until they provided the right answer" (Closa 2013: 131). The Yes camp countered these claims by emphasising the importance of the Treaty not just for Ireland, but also for the rest of the continent. Moreover, the context had changed due to the legislative changes and the Seville Declarations, which illustrated that the government had responded to the first 'No' and was now entitled to seek a reconsideration of the main question. Finally, the government framed another rejection around the highly symbolic issue of neutrality, although Nice had little that was new in the areas of security and defence.

Three frames dominated the second referendum campaign: first, like the Danes in 1992, the Irish Yes camp threatened that voting No again would mean withdrawal from the EU (Atikcan 2015: 946-48). Second, the EU put the Irish government under pressure to hold another referendum, because the first 'No' had plunged both the accession process and Ireland's relationship with the EU into crisis. The Nice Treaty was a vote for or against enlargement. Third, the non-ratification of the treaty was considered an 'Irish' problem: Irish political leaders repeatedly committed themselves (during the 2002 election campaign) to holding a referendum "on any changes that even approach the magnitude of those contained in the Nice Treaty." In effect, the first Nice referendum was not considered finally binding upon the government, as it aimed for overturning the decision by another referendum (Garry et al. 2005: 205). Compared to other ratification processes, the Irish rejection was stand-alone: there was no Court challenge, no other (negative) referendum or ratification problem in any other member state. This made it easy for the European partners to put pressure on the Irish to apply the 'Danish' Maastricht solution of a second referendum. 
Also the Irish No to the Lisbon Treaty resulted in a 17-month process that would eventually see the rejection reversed in a second referendum (Quinlan 2012: 140). How could this occur? On the one hand the usual replies from Brussels followed that ratification should continue, while on the other hand the economic crisis had a significant impact on the Irish position in the EU. As Ireland had solved its comparable problem with the Nice Treaty, there was French pressure for another second referendum. However, the Irish government feared that a quick second vote would result in an even larger 'No'. The opposition argued that the pressure placed on Ireland to re-run ratification was undermining the will of the Irish people and the democratic legitimacy of the EU. In order to provide an interparty protreaty consensus and make the parties jointly responsible, a parliamentary committee was commissioned to identify

"issues that should be taken into account in any possible future relationship (implying a solution). These included national control over taxation policy, the development and consolidation of a social market economy, the preservation of the role of the state in the provision of public services and the recognition that having a Commissioner was a matter of national sensitivity" (Closa 2013: 137).

The Irish parliament also reflected on Ireland's future position in the EU as a whole. The parliamentary report stated that ratification in parliament alone was not an option and that leaving the EU was 'unthinkable and catastrophic'. Finally, the report highlighted the possibility of a second referendum against which there were no legal obstacles.

In autumn 2008, negotiations started between the Irish government and other member states. Again the first referendum proved to be not so binding eventually. The defeat now enabled the Irish government to get concessions which were previously denied but of secondary importance to the EU (Rose 2018: 15). These included indeed the retention of a Commissioner per member state, an issue which had been central in the 2008 campaign, as well as some legal guarantees that the Lisbon Treaty would not affect Irish abortion, tax or neutrality policy. It submitted a Statement of Concerns to the December 2008 European Council, which agreed on certain guarantees. These guarantees would stand as an international agreement which would become an official protocol to be attached to the consolidated treaties after the next accession (envisaged for Croatia within some years). The European Council also issued a solemn declaration reaffirming workers' rights to meet the voters' concerns on this issue. Having reached this deal, the Irish government agreed to hold a second referendum in October 2009 (Closa 2013: 138).

At the same time though the economic crisis had hit Ireland severely. The Irish economy experienced its first recession since 1983. GDP fell by 11 percent and unemployment rose from 5 to 12 percent between 2008 and 2009. Some banks had to be recapitalized by the state, resulting in austerity budges including tax rises and cuts in public expenditure. Government popularity dropped and hence the context at the time of the second referendum had changed dramatically. But this time, Ireland's EU and Eurozone membership was considered a vital part of the solution. Like with the second Nice Treaty referendums, the Yes 
camp stressed the membership issue as well as the economic consequences in case of a second No. During the campaign the changed economic circumstances provided the opportunity to the Yes camp to campaign that the EU had a vital role to play in Ireland's economic recovery (Quinlan 2012:142-5). The second referendum would boil down to Ireland's future in or out the EU. In October 2009, a majority of Irish voted in favour of the Lisbon Treaty.

The three cases on the Maastricht, Nice and Lisbon Treaties show that EU pressure not to accept the result and the serious consequences of failure of the integration process push towards a second referendum. It has to be noted, though, that this strategy of circumventing the first referendum outcome is rather exceptional and inconvenient in international law on the ratification of treaties.

"It is difficult to imagine significant external pressure being imposed on a state which is engaged in deciding whether or not to join the World Trade Organization, the Council of Europe, or any other regional or international organization. If the matter is put to a popular vote in a given state and the vote is negative, the matter is generally concluded. The state in question does not join, the organization does not gain a new member, a "no" vote in the referendum is taken to mean no and all parties move on" (De Búrca 2011: 1476).

In fact, after negative membership votes, indeed no prospective Member State has been placed under external pressure to revise the accession terms and resubmit it to a second referendum. The crucial difference is that comprehensive amending treaties are not bilateraltype agreements between a (new) member state and the EU, but multilateral agreements which require unanimous ratification of all member states, giving each of them an effective veto over any treaty change affecting all member states. It demonstrates that the type of referendum matters by overcoming defeat.

Nevertheless, the practice of the ad hoc mechanism of a second referendum to sidestep the unwanted results of a legitimate ratification process remains a controversial, troubling and even unsatisfactory practice, from a normative point of view. First, the additional decisions and declarations cannot have the legal effect of amending the treaty whose ratification has been rejected. Second, the outcome of the treaty ratification procedure in line with each member states' domestic constitutional requirements (as laid down in Article 48 of the Treaty on the EU) is not being respected if it undermines the democratically expressed will of the citizens, even if the government has previously agreed to the common accord. In the Lisbon Treaty, an attempt was made to remove the unanimity requirement for future treaty reform. ${ }^{45}$ This hints to a political solution opening up the possibilities for the willing member states to move ahead. An alternative to abandon (or even prohibit) the requirement of a national referendum for the ratification of EU treaties remains a theoretical exercise. Only in the Netherlands the experience with the Ukraine referendum has caused the envisaged withdrawal of the Advisory Referendum Act. It is unlikely that other member states with more strongly, mostly constitutionally, grounded provisions for direct democracy will follow the same way. 


\subsection{Neglecting the result: 'it does not matter after all'}

The 2016 referendum in Hungary was called to legitimise the government's failed opposition against the EU's Justice and Home Affairs Council's decision adopting a policy of redistributing refugees among member states. Although Prime Minister Orbán declared victory over the 98 percent in the referendum, the low turnout of 40.4 percent rendered it invalid and consequently non-binding due to the required 50 percent threshold. Being legally redundant, the referendum would have no legal impact on the EU measure regulating the Union's policy of migrant resettlement, but its political implications are another matter. The EU regulation on the resettlement of 120,000 refugees has been hardly implemented. Therefore, the Hungarian referendum meant little more than a continuation of the status quo of the migration debate. Prime Minister Orbán called the result a big success and announced that the government will initiate a constitutional amendment in order to "anchor the will of the people in the constitution" (Pállinger 2017: 166). Slovakia and Hungary contested the Council of the EU's decision establishing the provisional relocation mechanism at the Court of Justice of the EU, by arguing that it was taken on an inappropriate legal basis and a neither suitable nor necessary response to the refugee crisis. In its judgement of September 2017, the Court dismissed all actions brought by Slovakia and Hungary (Court-of-Justice-of-theUnion 2017). This further weakened the Hungarian government's chances in Brussels. Given the absence of any constraints, neglecting the referendum and the Council decision resulted in retaining the status quo.

\subsection{Overview of the analysis}

Table 6.2 summarises the findings of the explorative study, ordered on the strategy which has been deployed. First, it reveals that the strategy of accepting the result in case of membership referendums is constrained by the fact that they were (at least politically) mandatory and binding. This made that at the domestic level there was no additional pressure needed on the government to accept the result, also because there was no pressure from the European level not to accept the result. There were no serious consequences looming at the EU level. Only in case of the French and Dutch rejection of the Constitutional Treaty, it was unsure whether the ratification process would go on, given the previous experiences to resolve partial ratification failures. Therefore, the domestic actors exerted pressures on the government to accept the result instead of to 'wait and see' what other countries would do. The other member states did not put pressure on the French and Dutch to continue their ratification process and called for a pause of reflection. As maintaining the status quo of the Nice Treaty was not considered a viable option either, after some time the renegotiation of the complete treaty returned on the agenda. 
Table 6.2. Constraints at domestic and European level of defeated referendums (cf. Figure 6.1).

\begin{tabular}{|c|c|c|c|c|c|c|c|}
\hline \multirow[t]{2}{*}{ Case } & \multirow[t]{2}{*}{ Subject } & \multicolumn{3}{|c|}{$\begin{array}{l}\text { Domestic level } \\
\text { constraints }\end{array}$} & \multicolumn{2}{|c|}{$\begin{array}{l}\text { European level } \\
\text { constraints }\end{array}$} & \multirow{2}{*}{$\begin{array}{c}\begin{array}{l}\text { Strategy } \\
\text { chosen }\end{array} \\
\text { Accept } \\
\uparrow \\
\downarrow \\
\text { Neglect }\end{array}$} \\
\hline & & $\begin{array}{c}1 . \\
\text { (Politically) } \\
\text { Mandatory }\end{array}$ & $\begin{array}{c}1 . \\
\text { (Politically) } \\
\text { Binding }\end{array}$ & $\begin{array}{c}2 . \\
\text { Pressure } \\
\text { to accept } \\
\text { result }\end{array}$ & $\begin{array}{c}2 . \\
\text { Pressure } \\
\text { not to } \\
\text { accept } \\
\text { result }\end{array}$ & $\begin{array}{c}3 . \\
\text { Serious } \\
\text { consequences } \\
\text { for EU }\end{array}$ & \\
\hline DEN2OOO & $\begin{array}{l}\text { EMU } \\
\text { Membership }\end{array}$ & + & + & $\circ$ & - & - & Status quo \\
\hline SWE2OO3 & $\begin{array}{l}\text { EMU } \\
\text { Membership }\end{array}$ & $(+)$ & $(+)$ & $\circ$ & - & - & Status quo \\
\hline NOR1972 & $\begin{array}{l}\text { EC } \\
\text { Membership } \\
\end{array}$ & $(+)$ & + & $\circ$ & - & - & Adaptation \\
\hline SWI1992 & $\begin{array}{l}\text { EEA } \\
\text { Membership }\end{array}$ & $(+)$ & + & $\circ$ & - & - & Adaptation \\
\hline NOR1994 & $\begin{array}{l}\text { EU Member- } \\
\text { ship }\end{array}$ & $(+)$ & $(+)$ & $\circ$ & - & - & Adaptation \\
\hline FRA2005 & $\begin{array}{l}\text { Constitutional } \\
\text { Treaty }\end{array}$ & - & + & + & - & + & Renegotiation \\
\hline NET2005 & $\begin{array}{l}\text { Constitutional } \\
\text { Treaty }\end{array}$ & - & - & + & - & + & Renegotiation \\
\hline GBR2O16 & $\begin{array}{l}\text { EU } \\
\text { Membership } \\
\end{array}$ & - & - & + & - & + & Interpretation \\
\hline SWI2O14 & \begin{tabular}{|l} 
Against mass \\
migration'
\end{tabular} & + & + & + & + & + & Interpretation \\
\hline DEN2O15 & $\begin{array}{l}\text { Opt-in JHA, } \\
\text { Europol }\end{array}$ & + & + & ० & - & + & Interpretation \\
\hline NET2O16 & $\begin{array}{l}\text { EU-Ukraine } \\
\text { association } \\
\text { treaty }\end{array}$ & - & - & + & + & + & Interpretation \\
\hline IRL2008 & Lisbon Treaty & + & + & + & + & + & $\begin{array}{l}2^{\text {nd }} \\
\text { referendum }\end{array}$ \\
\hline DEN1992 & \begin{tabular}{|l|} 
Maastricht \\
Treaty \\
\end{tabular} & + & + & + & + & + & $\begin{array}{l}2^{\text {nd }} \\
\text { referendum } \\
\end{array}$ \\
\hline IRL2001 & Nice Treaty & + & + & + & + & + & $\begin{array}{l}2^{\text {nd }} \\
\text { referendum }\end{array}$ \\
\hline HUN2O16 & $\begin{array}{l}\text { Resettlement } \\
\text { migrant quota }\end{array}$ & - & - & - & - & - & Negligence \\
\hline
\end{tabular}

$+=$ present $;$ - = absent; $\mathrm{O}=$ evident that the government would respect the result.

Second, the cases in which the result had to be interpreted share that the outcome has serious consequences for the EU and for the country involved. Having a second referendum on the same issue was not considered, either since it was not required if the outcome could be implemented without, but also because the government did not want another referendum on the issue, being afraid that it would be rejected again. Third, the strategy of a second referendum was deployed in three cases of comprehensive treaty reform, in which passing a referendum was indispensable in order to complete the ratification procedure in Denmark and 
Ireland, respectively. The government's position was furthermore constrained by pressures from both the domestic level to accept the first referendum outcome, and counter-pressures not to do so from the European level because this would stop the complete ratification process. Finally, the strategy to neglect the outcome was only deployed regarding the EU's resettlement quota of migrants. As the result was invalid, neither the Hungarian government nor the European counterparts had an interest in respecting the result. Both sides continued arguing that the other party should adapt its position, i.e. Brussels held that Hungary should implement the regulation, while Budapest maintained that the measure violated national sovereignty, despite domestic and foreign opposition. The strategy of ignoring the result has not been deployed in other cases.

\subsection{Conclusion}

"The referendum, it seems, has exposed the uncomfortable fact that the assumptions which exist at elite level within the EU that it is appropriate to try to shape referendum outcomes and overcome retrospectively those popular votes with which they are unhappy" (Tierney 2012: 183)

The main question in this chapter was how governments deal with inconvenient referendum outcomes. The following pattern of four strategies emerges when comparing the 15 defeated cases.

First, the Danish and Swedish rejections of joining the Euro simply meant accepting the outcome and retaining the status quo. They could be easily isolated from the larger course of the integration process. There was no political will, no alternative, nor external pressure to give up their Crown. Likewise, by not joining the EU or EEA, Norway and Switzerland took recourse to an adaptation strategy: for Norway this meant a slow approach towards the EC during the 1980 s by means of free trade agreements, and obtaining EEA membership during the 1990s. The Swiss rejection of EEA membership in 1992 meant alternative negotiations to (re)shape the relationship with the EU by means of bilateral, sectoral agreements. There was large political consensus in all instances that the result should be respected and implemented. Ignoring the outcome would have caused political suicide at the next elections. Political survival of the party or politicians involved was deemed more important than realising the policy objective. Brussels did not press to overturn the result in another referendum. Particularly the Scandinavian minority governments had little to gain by attempts to push through their preferences, while facing the risk to be ousted on a European issue. The strategy of accepting the outcome by renegotiations is only feasible if the outcome is framed as a 'European problem'. Then it is up to all member states to find a solution, irrespective whether some of them had already ratified or not. The French and Dutch No to the Constitutional Treaty caused an upheaval that eventually ruined the project. A second referendum was out of the question. Instead renegotiation proved not only to be possible, but vital for the continuation of the integration process. This time the No votes constituted a 
European problem. Domestic political actors immediately proposed to withdraw the treaty, while foreign actors were divided how to proceed: the remaining scheduled referendums in most other countries were shelved. Only an alternative treaty could solve the issue, by using a strategy to avoid ratification referendums as much as possible (Closa 2013: 165).

Second, for referendums on unilateral decisions the people's decision was interpreted by means of alternative policies. The interpretation process of the UK's exit from the EU including the disentanglement of 40 years of European integration demands a completely different approach compared to the adaptation process of Norway and Switzerland after their non-entrance to the EC/EU and EEA respectively. As the Brexit negotiations only started in spring 2017 and are supposed to be concluded by 2019, it is unclear yet how the future relationship between the EU and the UK will take shape. There are largely diverging preferences between the British and the EU-27 on the issues of access to the internal market and free movement rights of currently established EU nationals in the UK, plus the border issue between Ireland and Northern Ireland. How the Brexit result will be interpreted eventually remains to be seen until the conclusion of the Brexit negotiations.

Another complex dilemma faced the Swiss government when it was confronted with the binding popular initiative 'against mass immigration'. The Swiss parliament eventually stretched the political interpretation of the initiative to the edges in order to find a compromise which could both rely on a parliamentary majority and could appease the heated arguments with Brussels.

In fact, both the Swiss and Dutch parliaments proved to have the final say on the 2014 and 2016 popular votes initiated by citizens. The Dutch referendum on the EU-Ukraine Association Agreement is exceptional due to the non-binding nature of the referendum. Although pressure was put on the Dutch government to continue ratification, also the European partners had to give in a bit by providing the Dutch government a way out to ratify supported by an additional declaration of the European Council. This deal sufficed for the Dutch parliament to support the agreement eventually without ordering a second referendum. In this way, the Dutch outcome was skilfully interpreted. The Danish optingreferendum on Europol-related matters required another solution, because maintaining the status-quo would cause a lot of practical difficulties. The political elites accepted the results and looked for alternative means of cooperation with the EU based on broad domestic political support. A special arrangement to retain access to Europol data was designed.

A third elite strategy is to hold a second referendum on treaty ratification. If framed as a domestic problem, European partners press to continue the ratification process by means of additional declarations or protocols paving the way for such a second referendum. This external pressure made that the first referendum proved less finally binding than it seemed at first sight (Tierney 2012: 163). A prerequisite for this way out is that the domestic government and parliamentary majority are willing to follow this solution, i.e. that domestic and European preferences converge eventually. Actors in favour of ratification of these treaties interpreted the initial rejection along a constant line of argument: first the results of the referendum 
must be respected; but second, that renegotiation was not an option; and third, regardless of the referendum result, that the ratification process would continue in other Member States. Referendums could be repeated due to the change of circumstances between the first and the second consultations (Closa 2013), and sufficient domestic political and popular support for the second vote. In this way, the partial defection of the ratification of the Maastricht Treaty in Denmark, and the Nice and Lisbon Treaties in Ireland was to be corrected by means of additional declarations. In this way, the first No was circumvented, while a second No could have put the EU membership of the involved country at stake.

Finally, the strategy to neglect the outcome was only deployed in Hungary's referendum on the EU's resettlement quota of migrants. As the result was invalid, neither the Hungarian government nor the European counterparts had an interest in respecting the result.

Apart from the unexpected 'shock effect' that there was no permissive consensus on the European integration process in the country concerned, only in few instances the referendum result had knock-on effects in other member states. This usually occurred in referendums on the ratification of comprehensive treaties, which were constitutionally or legally required. Moreover, few of the defeats caused serious political consequences. Most governments saved their political careers after a negative vote and no early elections were called. Only the failed membership referendums in Norway in 1972 and the United Kingdom in 2016 caused the fall of the government and (early) elections. After the French and Dutch No to the Constitutional Treaty, French Prime Minister Raffarin was the only politician forced to resign. Instead of resignation, the governments tried to downgrade the importance of the issue when taking recourse to adaptation, renegotiation, interpretation or a second referendum on the initial agreement. By deploying the tactics of political backsliding, they tried to enforce some concessions from their European partners to save face and appease their electorate with a 'new' deal. In any case, 'buying time' proved to be vital to find an alternative solution for the inconvenient referendum outcome. 


\section{Notes}

1. For instance, is the real preference of the government to pursue more European integration? Or does the government rather want to depoliticise the issue? If the referendum was merely called in order to overcome internal divisions, within the government or the incumbent parties, the main interest is not to deliver on the issue at stake, but to maintain government unity.

2. The EFTA bodies comprise an EFTA supervisory body, EFTA Court, a Parliamentary committee of EFTA States and a Permanent Committee of EFTA States.

3. The Federal parliament decided on a proposal of the Federal government, that a 'mandatory' referendum was appropriate due to the political and economic significance of the agreement. An explicit constitutional base for this procedure was not provided. According to Art. 89 (3b and c) of the Swiss Constitution (version in force in 1992), international treaties providing for the accession to an international organization or an agreement for multilateral harmonization of laws, provide for an optional referendum.

4. The EFTA was founded in 1959 among Austria, Denmark, Norway, Portugal, Sweden, Switzerland and the UK. Iceland and Finland joined as full members in the 1960s and 1980s, respectively.

5. Notably, the CT contained a so-called rendez-vous clause, that if within 2 years $4 / 5$ of the member states had ratified and one or more countries were facing ratification difficulties, the matter would be referred to the European Council (Declaration 30 of the Final Act of the IGC).

6. Referendums on the Constitutional Treaty would be avoided in Spain, Luxembourg, the UK, Denmark, France, the Czech Republic, Poland, and Portugal.

7. EU Presidency Conclusions - Brussels, 21/22 June 2007: "The constitutional concept, which consisted in repealing all existing Treaties and replacing them by a single text called "Constitution", is abandoned."

8. Sweden's EU accession treaty of 1995 obliged it to join the Euro. However, one of the requirements for Eurozone membership is membership of the Exchange Rate Mechanism II. Sweden has not joined this mechanism and as a consequence tied its exchange rate to the Euro by $\pm 2.25 \%$.

9. Cameron had secured commitments on non-discrimination from countries outside the Eurozone, an exemption from 'ever closer union', plus a red card for national parliaments, improved competitiveness and the cutting of 'red tape', and changes to reduce EU nationals 'ability to secure welfare benefits: EU migrants should have of new member states should have no access to free movement until their country's economy converged sufficiently with the existing member states. EU migrants should have to live in the UK and contribute for four years before they could profit of British welfare benefits (Smith 2016).

10. Employers will be obliged to advertise vacant positions to job centres and invite Swiss job seekers for interview or risk a 40,000 franc fine. Employers must invite candidates who meet their criteria and who are registered at the local unemployment office for an interview, which obviously cannot apply to foreign workers registered elsewhere (Swissinfo.ch 2016). Moreover, EU citizens losing their job within the first year will have six months to leave the country (Osborne and Broomfield 2016).

11. Report on the European Council 28-29 June 2016, by the Dutch government (translated by the author): 
"Dutch referendum on the Association Agreement with Ukraine. The Prime Minister has outlined the situation resulting from the referendum outcome in the Netherlands on 6 April. He indicated that the agreement cannot simply be ratified. He mentioned some concerns which appeared during the debates preceding the referendum, such as the concern that this Association Agreement implies Ukrainian EU membership in the long run, the concern that it will lead to comprehensive additional financial obligations, and the fear that military cooperation also constitutes a security guarantee for Ukraine. A satisfying solution needs to be found which addresses these concerns. The Prime Minister has made clear that such a solution should be legally binding. He also emphasized that the Netherlands does not intend to wait very long with this. It is agreed upon in the conclusions that a solution addressing the raised concerns, should be found as soon as possible."

12. The Decision contains six clauses as common understanding that the Association Agreement

i) does not (constitute a commitment to) confer on Ukraine the status of candidate member state;

ii) does not contain an obligation for the EU or Member States to provide collective security guarantees or other military aid or assistance to Ukraine;

iii) does not grant EU or Ukrainian citizens to reside and work freely in each other's territories;

iv) does not require additional financial support by the Member States to Ukraine

v) puts the fight against corruption central to enhancing the relationship between the EU and Ukraine;

vi) puts respect for democratic principles, human rights and fundamental freedoms and respect for the principle of the rule of law as its essential elements (Council 2016a).

13. In the 1987 Crotty v An Toaiseach case, the government had been challenged when it thought not to hold a referendum on the Single European Act. The High Court's ruling that a referendum was required set a precedent for subsequent significant changes of EU treaties.

14. The 'National Declaration by Ireland' states that "Ireland is not party to any mutual defence commitment' and that 'Ireland is not party to any plans to develop a European army." The second declaration 'of the European Council' states that "Ireland's policy of military neutrality is in full conformity with the Treaties, on which the European Union is based...and that there is no obligation arising from the Treaties which would or could oblige Ireland to depart from that policy. (...) Further, the government inserted a clause in the referendum text guaranteeing that Ireland would not join any EU common defence" (Garry et al. 2005: 208).

15. If after two years after the signature of an amending treaty at least four-fifths of the member states have ratified and one or more member states encountered difficulties, the matter shall be referred to the European Council. 


\section{Conclusion and discussion}

Over the last decades the legitimation of the European integration process has been challenged by direct democratic decision-making in European countries. Between 1972 and 2016, 61 referendums related to the European Union were held. This study investigated under which conditions governments win such EU-related referendums. This research question emerges at a time of a growing number of referendums on European integration issues. As referendums are one of the few direct access points for voters to the EU-decision-making structure (Fitzgibbon 2018: 287), legitimising such far-reaching EU decisions by national referendums has become common in many European countries. Particularly the deepening of the integration process from the Maastricht Treaty (1992) onwards went along with a shift among the public from a 'permissive consensus' towards a 'constraining dissensus' on the EU (Hooghe and Marks 2009). This shift was paralleled with a perceived growing cleavage across Europe between winners of globalisation and those that feel left behind (Hobolt 2016). This cleavage has been demonstrated in national elections and popular referendums that have more often constrained than enabled the integration process (Jones 2018: 441). Nevertheless, this study shows that governments have been quite successful in securing popular support for their EU policies.

In order to understand why citizens support or reject European integration, scholars have been investigating referendum campaigns and factors that influence individual voting behaviour. However, there is still limited knowledge in the way that governments deal with EU-related referendums. Therefore, this study has taken a different approach. Its focus is not on the voter, but on the representative decision-makers, more specifically on the aggregate factors that cause the government to win or to lose the referendum. Despite ideas that referendum outcomes are determined by an arbitrary volatility of unchained voters partly driven by populist movements, this study attempts to explain referendum outcomes by means of reasoned policy-related variables.

Regarding the main research question this study shows that governments almost always win referendums when the economic development is bright and when the government relies on a large unified majority in parliament. However during economic decline, the government only wins if it is only recently in office and backed by a wide consensus among elites. A unified majority government and economic development are the main drivers for winning referendums. The other questions in this study addressed when, where and why the referendum was introduced in Europe, what the reasons are to trigger EU-related referendums and where these referendums have taken place. This study also researched alternative causal mechanisms in order to explain cases which turned out to be deviant in the main analysis. Finally, the consequences of defeated referendums have been explored. Several strategies have been identified in order to explain how governments cope with such inconvenient referendum outcomes. This chapter summarises the findings, discusses the broader implications and suggests prospects for future research. 


\subsection{EU-related referendums in historical perspective}

How and why did referendums enter the political scene in Europe? The entrance of referendums on European integration since 1972 should be located in the history of referendums in European countries covering more than two centuries. Since the French revolution of 1789, referendums have been introduced for three main reasons. First, referendums were called by (authoritarian) leaders in order to provide legitimacy to the decisions and constitutions of their regimes. This occurred during the Napoleonic era in France and the Swiss and Batavian Republics, during the interbellum by authoritarian regimes such as in Nazi-Germany, Austria and Italy, and during the interbellum and the communist eras in some central and eastern European countries.

Second, referendums were used to enforce independence of new states, such as Norway in 1905, Malta in 1963, and many states triggering the collapses of the Soviet Union and former Yugoslavia in 1991. The failed independence referendums in Scotland in 2014 and Catalonia in 2017 can also be regarded in this tradition. Third, referendums were introduced in many European states' new constitutional systems in response to the demand for more direct democratic participation by citizens. This occurred shortly after the First World War with the Weimar Constitution of 1919 as prime example. The 1968 revolts gave rise to the extended implementation of referendum provisions in re-democratised countries such as Italy, Spain, Greece and Portugal. Switzerland has been the exceptional frontrunner in this respect, as it introduced the referendum already in 1848 and extended its provision during the following 150 years. It has to be noted that in all these European states, even in Switzerland, the referendum is embedded in a representative system, as designed in each countries' legal tradition. "As there was no best regime according to Aristotle, there is probably no best referendum. Each country must give birth to its own model" (Morel 2018a). Moving beyond the existing paradigm of direct vs. representative democracy, these two forms function rather complementary instead of juxtaposed to each other. As Morel argues, the development of direct democracy in Europe presupposes a pact of trust between the representatives and the represented. Finally, the evolution of the European Union added a new dimension to the demand for referendums in European countries. The increasing transfer of powers from the member states to the EU implied that more frequently direct democratic decision-making was required or desired to legitimize this pooling of sovereignty.

\subsection{Calling referendums}

What are the reasons to hold EU-related referendums? This question can be split into two parts. First, whether a referendum is required, and second, what the motives are to opt for a referendum in case it is not required. A referendum is mandatory or optional. If mandatory, the referendum is prescribed by the constitution, by ordinary law or by court. If the referendum is optional, it is up to the government, the parliament or the citizens to call the referendum. If citizens do so, the referendum is called a popular initiative (to propose a new bill) or a popular 
veto (to reject an existing bill).

What are the institutional constraints in Europe for holding referendums? When comparing 43 current European democratic states, 39 countries provide regulations for referendums on European integration. No country has explicitly ruled out referendums on any issue related to European integration. Several countries even organised referendums based on ad hoc legislation. 19 countries require referendums in case of constitutional amendments, and 11 countries do so in case of any (future) transfer of powers to or membership of international organisations such as the EU. In Denmark this obligation is lifted if a fivesixth majority of parliament approves the transfer of powers. In a handful of countries, the government can autonomously trigger an optional referendum. More often they are dependent on parliamentary approval and hence parliaments have much more opportunities to trigger EU-related referendums. To a lesser extent citizens can enforce popular initiatives. It is remarkable though that six countries provide for referendums called by their parliaments, but at the same time prohibit popular initiatives on the EU-related issue.

Why would optional referendums be triggered? Two overriding reasons can be identified: partisan calculus and appropriateness. Partisan calculus can aim to reinforce the power of the government vis-à-vis political opponents, to mediate internal divisions within the government or within or between political parties, to depoliticise a salient issue. It can also have a policy-seeking motive for instance to circumvent an opposing parliamentary majority. Governments pledge offensive referendums in order to realize potential political gains, to improve on the status quo and proactively pursue their agenda. Alternatively, governments pledge defensive referendums in order to avoid potential political losses facing elections or policy objectives at the European level, particularly when the EU is unpopular and elections are close. Reasons of appropriateness prevail when there is strong domestic pressure, precedents or the domino effect from other countries to hold a referendum.

Which EU-related referendums have actually taken place and why? The analysis shows that 19 of the 61 EU-related referendums were mandatory (excluding two by parliaments purposely designed constitutional provisions for EU accession), and 42 were optional. Governments triggered 9 referendums mainly due to power-reinforcing motives or for reasons of appropriateness. Parliaments triggered 21 referendums for reasons of appropriateness and to a lesser extent for mediating reasons. Citizens triggered 12 referendums for policy-seeking reasons, either to promote a new initiative, or to block a proposal from elected representatives. Notably, 11 out of 12 citizen-initiated referendums took place in Switzerland.

Actually, half of all the EU-related referendums (31 of 61) took place in only four countries: Switzerland (11), Ireland (9), Denmark (8) and France (3). There are three reasons for the limited practice in other countries. First, governments or parliaments felt no need to hold a referendum: the political actors considered referendums as a risk to block their European policy objectives. The avoidance of referendums on the ratification of the Lisbon Treaty shows that the legitimacy concerns were no longer linked to the necessity of holding a 
referendum, as they had been at the time of the many referendum pledges for the ratification of the Constitutional Treaty. A second explanation is the limited potential for citizeninitiated referendums on EU matters: 11 out of 22 potential countries exclude citizen-initiated referendums on treaty ratification. Even countries with a rich referendum tradition like Denmark and Ireland do not provide for popular initiatives on EU matters. A third reason for the limited practice are the hurdles to trigger the citizen-initiated referendums: the number of required signatures is rather high. Moreover, countries use turnout and/or approval quorums which pose additional thresholds on the validity of the result and hence on the envisaged effect of the referendum.

\subsection{Winning referendums}

The analysis revealed that governments won 46 out of 61 EU-related referendums. Why did they succeed or fail? While individual preferences may explain the effects of certain individual level causes, they do not explain the causes of an effect. Hence instead of focusing on competing explanations, such as salience of the issue, EU support or government support by individual voters, it is argued here that most aggregate explanatory factors are interrelated or interacting and should be regarded as configurations. This study distinguished four aggregate political-institutional conditions (majority government, elite consensus, recent elections, and offensive referendum strategy), and two socio-economic conditions (economic prosperity, and becoming EU net recipient) that could explain government victory. The model could correctly explain 44 out of 46 government victories and 14 out of 15 government defeats.

One needs to acknowledge from a normative point of view that there are different types of EU-related referendums: related to membership issues, related to treaty ratification, and related to other policy issues. These types deal with fundamentally different questions, i.e. joining or leaving the EU is another matter than ratifying a reform treaty. Hence, it is argued that the referendum type functions as a contextual specification mediator which has an impact on the effect of (combinations of) explanatory factors.

The three analyses of referendums provide for different causal configurations towards a successful outcome, all with high consistency and coverage values. The fsocA analyses reveal that when the economy is booming and the government has a unified majority in parliament, governments almost always win. If the economy is deteriorating, however, the government only wins if it is only recently in office and backed by a wide consensus among elites. The analyses show that a unified majority government and economic development are the main drivers for winning referendums. Within the total number of 10 successful solution terms, having a majority government appears 7 times while positive economic development appears in 5 configurations. The government hardly wins if both factors are absent. Hence, governments can utilise times of economic prosperity and political stability when holding referendums. This confirms that aggregate causal patterns for government success are found in configurations of combinations of conditions (conjunctions) or alternative solution paths 
(equifinality). When ratifying comprehensive EU treaties, an offensive referendum strategy by the government proves as a necessary condition, in most cases in combination with economic prosperity. This implies that if the government is in a defensive position to hold a referendum on the ratification of such a treaty, it can hardly win.

The theoretical propositions could be confirmed in some of the analyses, while in other they were not empirically identified. The first proposition expected that political stability on the issue (a unified majority government combined with elite consensus) would contribute to a government victory. This proposition is only partly confirmed: it requires at least the presence of one other condition in order to be sufficient for the outcome. This means that a majority government cannot just rely on elite consensus, but needs to be escorted by either economic prosperity (in membership referendums) or it needs to enjoy its honeymoon period (and deploy an offensive referendum strategy; in case of treaty referendums). The second proposition utilises economic prosperity, by expecting that the government wins if it follows an offensive referendum strategy in economic good times. This expectation is fully confirmed in among treaty referendums, and partly confirmed in the set of membership referendums (also in combination with becoming an EU net recipient). The proposition is rejected among policy referendums, however. Instead, successful policy referendums are explained by factors of political stability, having a majority government as a dominant factor.

The analyses show that the high number of government successes (3/4) is strongly related to institutional advantages that governments possess over the opposition, in terms of their majority government, elite consensus and the time that they have been in office. Moreover, before the referendum is called, governments shape the EU-related policy proposal at the negotiation table and possibly change it to their preferred direction by issuing referendum threats. They have influence on the timing of the referendum and will commit themselves to the issue at stake which they presume is favourable to the country (cf. Schneider 2018: 426).

The analysis of governments which lost referendums reveals that membership referendums are defeated when they feature the combination of a minority government which has been long in office, choosing a defensive referendum strategy and not being a prospective EU net recipient. Governments which have been long in office tend to lose treaty referendums in times of economic downturn. The reasons for losing policy referendums are less clear-cut and feature a defensive referendum strategy and elite polarisation, either in combination with a minority government, or in combination with economic downturn and a government whose honeymoon is over.

The typology of membership, treaty and policy referendums is well applicable in the framework of this study, because the distinction proves to be a meaningful contextual mediator, in which different mechanisms are at play. No similar pattern could be identified across the three types of referendums, i.e. none of the solution paths appears similarly in any of the two other analyses, neither in the analysis of winning referendums nor in the analysis of losing referendums. 
Two successful cases and one unsuccessful case could not be explained by the provided solution terms of the analyses: the second Irish referendum on the Lisbon Treaty (2009), the Danish referendum on the EU's Patent Court (2014), and the Danish referendum on joining the Euro (2000). The comparative process-tracing analysis of these deviant cases coverage unfolded two additional conditions. First, the urgent need for economic recovery with EU assistance seems to be the distinguishing factor for the Irish case compared to the lost referendums on the Lisbon Treaty (2008) and the Constitutional Treaty (2005). Second, concerns on a transfer of sovereignty played a distinctive role in the referendum on the introduction of the Euro (2000), but remained largely untouched in the debate on the participation to the European Patent Court (2014). By adding these conditions to the analyses, the three deviant cases could be resolved.

\subsection{Dealing with inconvenient referendum results}

How should a government deal with a defeated referendum? This question has hardly been addressed so far in the literature on EU-related referendums or on referendums in general. This study compared and reconstructed the 15 lost referendums. It proposed a new model that explores why governments can choose between four particular strategies to deal with the referendum outcome. A first strategy is to accept the outcome. This strategy can take three forms: retaining the status quo, adaptation or renegotiation. The form of retaining the status quo is deployed when there is no political alternative and no external pressure to change the result. In most cases the referendum was mandatory and binding. This occurred when Denmark and Sweden rejected to join the Euro in the early 200os. Another way of accepting the outcome is adapting to the new situation. When Norway rejected EU membership in 1972 and in 1994, and Switzerland rejected EEA membership in 1992, both countries sought alternative ways of bilateral cooperation with the EU. This strategy is accompanied by large domestic political consensus to respect and implement the result, without pressure from Brussels to overturn it. A third form to accept the result is to renegotiate the initial agreement. This occurs if the referendum outcome is framed as a 'European problem' and there is no pressure to overturn the result. Instead, there is large consensus to renegotiate and hence a second referendum on the issue is out of the question. The ratification failure of the Constitutional Treaty of 2005 was resolved in this way, resulting in the renegotiated Lisbon Treaty, which ratification by referendum was avoided as much as possible.

A second strategy is to interpret the outcome, when there is disagreement how the referendum result should be implemented. There are no 'contingency plans' available and straight implementation or retaining the status quo would have serious consequences both for the EU and the country involved. Creative interpretation skills were demanded from the Swiss political actors to implement the binding result of the approved popular initiative 'against mass migration'. A strict interpretation would have set many bilateral agreements on hold, very much against the interests of the mainstream Swiss political, societal and business establishment. Eventually a soft solution 'Domestic priority light' was found, which did in fact 
not put any curbs on immigration. Also the non-binding Dutch rejection of the EU-Ukraine Association Agreement forced the Dutch government to skilfully interpret this outcome by negotiating an additional interpretative declaration in Brussels. Likewise the Danish political elites looked for alternative means of cooperation with the EU after the rejection of Danish participation in Europol. Finally, the rejection of British EU membership forces the UK to look for alternative relationships with the trading block. How the future relationship between the EU and the UK will look like, remains to be seen after the conclusion of the Brexit negotiations.

The third strategy is to circumvent the outcome by means of a second referendum on the issue, as practiced after the Danish No the Maastricht Treaty in 1992 and the Irish No to the Nice and Lisbon Treaties in 2001 and 2008. The 'partial defection' of the ratification process was framed as 'Danish' or 'Irish' problem. Despite domestic pressure to accept the mandatory and binding outcome of the referendum, external pressures from mainly the EU and other member states to hold a second 'rebound' referendum to complete the ratification process, made that the first referendum proved less finally binding than it initially seemed.

A fourth strategy to neglect the outcome was only deployed in Hungary's referendum on the EU's resettlement quota of migrants. This referendum was easily to ignore for both the Hungarian government and its European counterparts, because the result was invalid as the turnout threshold was not met.

The analysis shows that referendums results are not irreversibly set once and for all. Although it seems that questioning the will of the citizens is much more difficult than reversing the will of the elected after new elections, the four strategies that have been deployed demonstrate that governments have been able to skilfully adapt, renegotiate, interpret or even circumvent inconvenient referendum outcomes. The implementation of inconvenient referendum results is hardly a one-to-one translation of the referendum result. For instance, the pressure of European leaders in 2015 on Greek Prime Minister Tsipras to accept harsh austerity measures proved stronger than the voice of the majority of the Greek citizens who had been hastily called to reject the austerity package. Even though the referendum result was a victory for Tsipras' government, its implementation would be so disastrous for the Eurozone that it was eventually overruled.

Hence, a referendum defeat for the government hardly means a complete downfall, neither in terms of its policy objectives nor in terms of the government's own survival. It is remarkable that only three out of 15 failed referendums caused the resignation of the government: Norway's rejected EC membership in 1972, the UK's Brexit vote in 2016 and the dismissal of the French Prime Minister Raffarin in 2005 after the vote on the Constitutional Treaty. The analysis how governments deal with inconvenient outcomes demonstrates that in the vast majority of cases, the governments have it 'their way' in one form or the other. The people's direct democratic voice is heard, but it hardly has the very last say in the ongoing European integration process. 


\subsection{Implications}

What is the use of referendums in the European integration process? Direct democracy has challenged the evolution of the European Union over the last 50 years and will continue to do so probably even more. Many far-reaching decisions on European integration have been legitimised by referendum. However, direct democracy has also set some limits to the widening and deepening of the integration process. The referendum has become a constraining device given the growing failure rate for governments over the last two decades. Citizens in Norway and lastly in the UK have rejected membership of the EU, Swiss citizens rejected to join the EEA, while and Danes and Swedes have prevented their countries to join the Eurozone. Citizens in France and The Netherlands blocked the completion of the ratification process of the Constitutional Treaty, while a majority of voters in Denmark and Ireland delayed the ratification process of the Treaties of Maastricht, Nice and Lisbon, respectively. Actually, the Danish opt-outs resulting from the first No to the Maastricht Treaty meant the start of a multi-speed Europe. This Europe à la carte has proved as a suitable way to solve domestic referendum issues. Denmark's referendum experience enforced it to opt-out of the Eurozone, European defence, freedom, security and justice (including Europol), while the Swedish referendum enforced to stay outside the Eurozone as well. After Brexit, the EU is probably more prone to differentiated integration or even disintegration.

Next to enabling and constraining the course of the integration process, referendums on EU issues can also provide a way out of a political impasse, for instance when governments and parties are internally divided. Then referendums are used strategically in inter- and intraparty competition, to mask these internal divisions and to depoliticise the issue, especially in a context of rising fragmentation of party systems and electoral volatility (Hollander 2016: 268, 273). This study has shown that research of EU-related referendums should take the strategic context under which these referendums take place (or under which they are avoided) into account (Schneider 2018: 428).

What does the referendum mean for the future of the EU? Brexit has shown the vulnerability associated with such referendums and may even affect future accession referendums in prospective member states, such as on the Balkan (Hobolt 2016: 1273). Notably, the rejection of the Constitutional Treaty gave rise to a French constitutional revision in 2008 which implies that any prospective EU accession is subject to a mandatory referendum in France. Should the referendum become the norm in far-reaching EU decision making in order to enhance the legitimacy and decrease the perceived democratic deficit of the integration process? The referendum can now be considered as established part of the decision-making process which provides the opportunity to change EU policy issues, by or as a result of a direct democratic vote. As insiders, representatives have already many opportunities beyond the referendum to influence the EU's policy making process. By calling a referendum, also outsiders of EU policy formation have an incentive to challenge the EU-related issue in question (Fitzgibbon 2018: 287).

Two limitations of the referendum should be mentioned in this respect. First, one 
should realise that from the start European integration has been a process of redistribution and bargaining during negotiations between and within the EU's institutions and member states. It would be inconceivable to submit all far-reaching decisions of EU policy makers to a referendum. Second, the referendum is a tool for collective decision-making, but not for collective policy building as is characteristic for the EU's decision-making process. In a referendum voters are not part of this policy building process. Instead, they have to choose between options that have been formulated by others (Morel 2018a: 159). There is no space for citizens to give and take, as there is for their representatives during negotiations. This makes it difficult for both citizens and their representatives to deal with referendum questions, especially if the outcome is inconvenient to them. These two limitations show that the referendum is not the saviour for the EU's perceived lack of legitimacy. It should be treated as one of the tools within the states' direct and representative decision-making mechanisms. Particularly how governments deal with inconvenient referendum outcomes illustrates the interplay of direct and representative democracy.

What is the future role of EU-related referendums? On the one hand, more referendums are expected because of the growing impact of the European integration process on the day-to-day decision-making, and due to the increasing politicisation of the EU's policies in the domestic arena. The era of permissive consensus is over. The breakthrough of Eurosceptic parties demanding more direct democracy on European issues may pressure governments to commit to referendums, which may trigger also votes in other countries (Oppermann 2018: 252). The changing position of the referendum in the UK is a prime example. Whereas British Parliament had been able to resist Eurosceptic demands for a referendum for a long time, since the adoption of the 2011 European Union Act, the independence referendum in Scotland in 2014 and the 2015 European Union Referendum Act, the national referendum definitely seems to have entered the British political system. The British parliament is not the only highest political actor anymore.

On the other hand, the negative referendum experiences and the wariness towards more integration may hint at less referendums. Particularly the Brexit result may imply that referendums are less likely to occur in other EU countries. Also the envisaged withdrawal of the Dutch Advisory Referendum Act after the government's negative referendum experience on the EU-Ukraine Association Agreement hints at less opportunities for direct democracy on European matters. Referendum avoidance can also be observed on other issues. Apart from referendums on the introduction of the Euro in Denmark and Sweden, no other countries so far held plebiscites on the single currency, despite popular criticism in some Central and Eastern European Countries which have introduced it recently. Furthermore, despite repeated calls for transnational or pan-European referendums, it is not likely that this internationalisation of the instrument will be introduced at the European level soon (Morel 2018a: 151). 


\subsection{Limitations and future research}

In terms of the external validity of the findings, it can be argued that the results allow for modest generalisation of the causal inferences applicable to those cases reflecting similar circumstances. Hence, in future cases one could take into account the combination of identified aggregate circumstances that in the past provided patterns for the government to win the referendum. In order to identify which combinations of factors cause governments to win referendums, fuzzy-set Qualitative Comparative Analysis proved to be a suitable method. To correctly infer the outcome of EU-related referendums based on aggregate level conditions is a new approach in political science literature. Fuzzy-set OCA provides a comprehensive understanding of the causes of an effect: winning or losing the referendum. Though the implications of the results are limited in some respects. The results of these qualitative comparative analyses do not predict every individual (future) EU-related referendum. OCA is an inductive approach, dependent on the empirical population of cases which means that it is more theory-building than theory-testing. Furthermore, the analyses do not assess each individual case in depth and only take into account the finally selected conditions. This means that several underlying factors of the causal mechanism could not have been fully incorporated, for instance particular events of or the general course of the campaign preceding the referendum. These factors could be analysed further by comparative process tracing. Moreover, the analyses were limited to the population of EU-related referendums, so the factors impacting on their outcomes have not been tested on referendums on other issues at the local, regional or national level or beyond European countries. Finally, because this study has focused on the position of the government when calling, winning and interpreting the referendum, no emphasis has been laid on the course of the referendum campaigns, as has been done in other studies.

This study's findings may trigger a further examination of EU-related referendums. As it has focused on aggregate level factors, future studies could investigate more the impact of the role of governments in the referendum campaigns on the individual voters and public opinion in general. For example, to what degree does timing of the referendum play a strategic role in decisions of governments and political parties to pledge referendums? Another issue is how political elites take into account previous referendum experiences in current EU policy making processes. What will this mean for referendum cases that will likely occur in the short or medium term? A final topic beyond this study is the viability of the referendum instrument in the complex system of EU policy making. The domestic and European level are so much interrelated, that the impact of a single -negative- vote is hardly the end of the decisionmaking process. As the strategies how governments deal with inconvenient outcomes have shown, the referendum is rather the beginning of it. 


\section{References}

Aarts, K. \& Van der Kolk, H. 2006. Understanding the Dutch "No": The Euro, the East, and the Elite. Political Science and Politics, 39, 243-246.

Albi, A. 2005. EU Enlargement and the Constitutions of Central and Eastern Europe, Cambridge, University Press.

Archer, C. 2005. Norway outside the European Union: Norway and European integration from 1994 to 2004, London, Routledge.

Atikcan, E. 2013. Direct Democracy: Remedying the Democratic Deficit? In: Laursen, F. (ed.) The EU and the Eurozone Crisis. Policy Challenges and Strategic Choices. London: Routledge.

Atikcan, E. 2015. The Puzzle of Double Referendums in the European Union. Journal of Common Market Studies, 53, 937-956.

Auer, A. 2016. Editorial: The people have spoken: abide? A critical view of the EU's dramatic referendum (in)experience. European Constitutional Law Review, 12, 397-408.

Aylott, N. 2003. The Swedish Referendum on EMU of September 14 2003. In: Network, European Parties Elections and Referendums (ed.) Referendum Briefing. Sussex.

Batory, A. 2018. EU Referendums in the 'New' Member States: Politicisation after a Decade of Support? In: Leruth, B., Startin, N. \& Usherwood, S. (eds.) The Routledge Handbook of Euroscepticism. Abingdon: Routledge.

BBC. 2003. Sweden says No to euro. BBC, 15 September 2003.

BBC. 2017. David Davis warned over Brexit vote promise for MPs. BBC, 26 October 2017.

Berg-Schlosser, D., De Meur, G. , Rihoux, B. \& Ragin, C. 2009. Qualitative Comparative Analysis (OCA) as an Approach. In: Rihoux, B. and Ragin, C. (ed.) Configurational Comparative Methods: Qualitative Comparative Analysis (OCA) and Related Techniques. London: SAGE.

Bjørklund, T. 1982. The Demand for Referendum: When Does It Arise and when Does It Succeed? Scandinavian Political Studies, 5, 237-258.

Blatter, J. \& Haverland, M. 2012. Designing Case Studies: Explanatory Approaches in Small-N Research, Basingstoke, Palgrave Macmillan.

Bogdanor, V. 1994. Western Europe. In: Butler, D. \& Ranney, A. (eds.) Referendums around the world: the growing use of direct democracy. Washington D.C.: American Enterprise Institute for Public Policy Research.

Brady, H. \& Kaplan, C. 1994. Eastern Europe and the Former Soviet Union. In: Butler, D. \& Ranney, A. (eds.) Referendums Around the World: The Growing Use of Direct Democracy. Hampshire: Palgrave Macmillan.

Butler, D. \& Ranney, A. 1978. Referendums. A Comparative Study Of Practice and Theory, American 
Enterprise Institute for Public Policy Research.

Butler, D. \& Ranney, A. 1994. Referendums around the world: the growing use of direct democracy, Washington D.C., American Enterprise Institute for Public Policy Research.

Cacciatore, F., Natalini, A. \& Wagemann, C. 2015. Clustered Europeanization and national reform programmes: a qualitative comparative analysis. Journal of European Public Policy, 22, 1186-1211.

Cini, M. 2004. Culture, Institutions and Campaign Effects: Explaining the Outcome of Malta's EU Accession Referendum. West European Politics, 27, 584-602.

Closa, C. 2007. Why convene referendums? Explaining choices in EU constitutional politics. Journal of European Public Policy, 14, 1311-1332.

Closa, C. 2013. The Politics of Ratification of EU Treaties, London, Routledge.

Commission, European 2015. Declaration to minimise the negative effects of the Danish departure from Europol, following the referendum in Denmark on 3 December 2015. Declaration by the President of the European Commission, Jean-Claude Juncker, the President of the European Council, Donald Tusk and the Prime Minister of Denmark, Lars Løkke Rasmussen.

Commission, European 2017. Working paper “Essential Principles on Citizens' Rights”. In: TEU, Task Force for the Preparation and Conduct of the Negotiations with the United Kingdom under Article 50 (ed.). Brussels.

Council, European 1992. Conclusions of the Presidency - Edinburgh, December 12, 1992. Brussels.

Council, European 2005. Declaration by the Heads of State or Government of the member States of the EU on the ratification of the Treaty Establishing A Constitution for Europe (16 and 17 June 2005). SN 117/05 ed. Brussels.

Council, European 2016a. Conclusions 15 December 2016. EUCO 34/16.

Council, European 2016b. Conclusions 18/19 February 2016.

Court-of-Justice-of-the-Union 2017. The Court dismisses the actions brought by Slovakia and Hungary against the provisional mechanism for the mandatory relocation of asylum seekers. Judgment in Joined Cases C-643/15 and C-647/15 Slovakia and Hungary $v$ Council.

Crum, B. 2007. Party Stances in the Referendums on the EU Constitution: Causes and Consequences of Competition and Collusion. European Union Politics, 8, 61-82.

De Bruyn, M. 2012. The Irish Referendums on the Lisbon Treaty: Did the Recession Save Lisbon? Journal of Contemporary European Studies, 20, 91-101.

De Búrca, G. 2011. If at First You Don't Succeed: Vote, Vote Again: Analyzing the Second Referendum Phenomenon in EU Treaty Change. Fordham International Law Journal, 33, 1472-1489.

De Vreese, C. (ed.) 2007. The dynamics of referendum campaigns in international perspective, London: Palgrave.

De Vreese, C. \& Boomgaarden, H. 2007. Immigration, Identity, Economy and the Government: 
Understanding Variation in Explanations for Outcomes of EU-related Referendums. In: De Vreese, C. (ed.) The dynamics of referendum campaigns: an international perspective. Basingstoke: Palgrave MacMillan.

De Vreese, C. \& Semetko, H. 2004. Political Campaigning in Referendums: Framing the referendum issue, London, Routledge.

Direct Democracy Navigator. 2016. Online database. Available: http://www.direct-democracy-navigator. org/

Dür, A. \& Mateo, G. 2011. To Call or Not to Call? Political Parties and Referendums on the EU's Constitutional Treaty. Comparative Political Studies, 44, 468-492.

Dutch-Coalition-agreement 2007. Samen werken, samen leven. Coalition agreement CDA - PvdA ChristenUnie.

Dutch-Coalition-agreement 2017. Confidence in the Future VVD - CDA - D66 - Christian Union.

Dutch-Council-of-State 2007. Opinion of 12 September 2007 on the mandate of the Intergovernmental Conference to revise the Treaty on the European Union and the Treaty establishing the European Community.

Dutch-Council-of-State 2017. Rapport over voorstel tot intrekking van de Wet raadgevend referendum.

Dutch-Government 2007. Advies en nader rapport EU-verdragsherziening. Tweede Kamer.

Eder, C. 2010. Ein Schlüssel zum Erfolg? Gibt es ein Patentrezept für Volksentscheide in den deutschen Bundesländern? Politische Vierteljahresschrift 51, 43-67.

Eichenberg, R. \& Dalton, R. 2007. The Transformation of Public Opinion on European Integration. Acta Politica 42, 128-52.

Elzinga, D.J. 1988. De waarde van een relatief rechtsbegrip, Groningen, Wolters-Noordhoff.

Erne, R. 2004. Direct Democracy in Italy In: Waters, Bruno Kaufmann and M. Dane (ed.) A Comprehensive Reference Guide to the Initiative and Referendum Process in Europe. Durham, North Carolina: Carolina Academic Press.

EuropaNu. n.d. Totstandkoming Verdrag van Lissabon. EuropaNu.

Europe, Council of 2013. Electoral Law. European Commission for Democracy through Law (Venice Commission).

European Commission 2015. EU Expenditure and Revenue. 2000-2014.

Evans-Pritchard, A. 2000. Blow to euro as Danes vote No. The Telegraph, 29 September 2000.

Finke, D \& König, T 2009. Why risk popular ratification failure? A comparative analysis of the choice of the ratification instrument in the 25 Member States of the EU. Constitutional Political Economy, $20,341-365$.

Fitzgibbon, G. 2018. When 'No' means 'Yes': A Comparative Study of Referendums in Denmark and Ireland. 
In: Leruth, B., Startin, N. \& Usherwood, S. (eds.) The Routledge Handbook of Euroscepticism. Abingdon: Routledge.

Font, J. \& Rodríguez, E. 2009. Intense but useless? Public debate and voting factors in two referendums in Spain In: Setälä, M. \& Schiller, T. (eds.) Referendums and Representative Democracy : Responsiveness, accountability and deliberation. New York: Routledge.

Fossum, J. 2009. Norway's European Conundrum. ARENA Working Paper (online) [Online].

Franklin, M., van der Eijk, C. \& Marsh, M. 1995. Referendum Outcomes and Trust in Government: Public Support for Europe in the Wake of Maastricht. West European Politics, 18, 101-117.

Gallagher, M. \& Uleri, P. (eds.) 1996. The referendum experience in Europe, Basingstoke: MacMillan.

Garry, J., Marsh, M. \& Sinnot, R. 2005. 'Second-order' versus 'Issue-voting' Effects in EU Referendums. European Union Politics, 6, 201-221.

Gay, O. \& Miller, V. 2013. Regulation of Referendums. In: Library (ed.). London: House of Commons.

Gifford, C. \& Wellings, B. 2018. Referendums and European Integration: The Case of the United Kingdom. In: Leruth, B., Startin, N. \& Usherwood, S. (eds.) The Routledge Handbook of Euroscepticism. Abingdon: Routledge.

Gouveia, J.B. 2011. Constitutional Law in Portugal, Alphen aan den Rijn, Kluwer Law International.

Harmsen, R. 2005. The Dutch Ratification of the Referendum on the European Constitutional Treaty. In: Network, European Parties Elections and Referendums (ed.) Referendum Briefing. Sussex: University of Sussex.

Henderson, K. 2004. EU Accession and the New Slovak Consensus. West European Politics, 27, 652-670.

Hinterleitner, M., Sager, F. \& Thomann, E. 2016. The politics of external approval: Explaining the IMF's evaluation of austerity programmes. European Journal of Political Research, 55, 549-567.

Hobolt, S.B. 2005. When Europe Matters: The Impact of Political Information on Voting Behaviour in EU Referendums. Journal of Elections, Public Opinion and Parties, 15, 85-109.

Hobolt, S.B. 2006. Direct Democracy and European Integration. Journal of European Public Policy, 13, 153166.

Hobolt, S.B. 2007a. Campaign Information and Voting Behaviour in EU Referendums. In: De Vreese, C. (ed.) The dynamics of referendum campaigns: an international perspective. Basingstoke: Palgrave MacMillan.

Hobolt, S.B. 2007b. Taking Cues on Europe? Voter competence and party endorsements in referendums on European integration. European Journal of Political Research 46, 151-182.

Hobolt, S.B. 2009. Europe in Question. Referendums on European Integration, Oxford, Oxford University Press.

Hobolt, S.B. 2016. The Brexit vote: a divided nation, a divided continent. Journal of European Public Policy, 23, 1259-1277. 
Hobolt, S.B. \& Brouard, S. 2011. Contesting the European Union? Why the Dutch and the French Rejected the European Constitution. Political Research Quarterly, 64, 309-322.

Hobolt, S.B. \& Leblond, P. 2009. Is My Crown Better than Your Euro? Exchange Rates and Public Opinion on the European Single Currency. European Union Politics, 10, 202-225.

Hobolt, S.B. \& Riseborough, P.L. 2005. How to Win the UK Referendum on the European Constitution. The Political Quarterly, 76, 241-252.

Holbrook, T. 1996. Do campaigns matter?, London, SAGE Publications Ltd.

Hollander, S. 2016. The People or the Prince: The politics of referendum use in European democracies. PhD Dissertation, Radboud Universiteit Nijmegen.

Hooghe, L. \& Marks, G. 2009. A Postfunctionalist Theory of European Integration: From Permissive Consensus to Constraining Dissensus. British Journal of Political Science, 39, 1.

Hug, S. 2009. Some Thoughts about Referendums, Representative Democracy and Separation of Powers. Constitutional Political Economy, 20, 251-266.

Hug, S. 2002. Voices of Europe: citizens, referendums and European integration, Lanham, MD, Rowman \& Littlefield Publishers.

Hug, S. \& König, T. 2002. In View of Ratication: Governmental Preferences and Domestic Constraints at the Amsterdam Intergovernmental Conference. International Organization, 56, 447-476.

Hug, S. \& Schulz, T. 2005. Referendums in the EU's Constitution Building Process. DOSEI Final Conference. Brussels.

Hug, S. \& Sciarini, P. 2000. Referendums on European Integration. Do Institutions Matter in the Voter's Decision? Comparative Political Studies, 33, 3-36.

Hug, S. \& Tsebelis, G. 2002. Veto Players and Referendums Around the World. Journal of Theoretical Politics, $14,465-515$.

Ibolya, T. 2015. A vote of no confidence: explaining the Danish EU referendum. OpenDemocracy.net.

IDEA 2016. Direct Democracy Database. Institute for Democracy and Electoral Assistance.

Jenssen, A.T., Pesonen, P. \& Gilljam, M. (eds.) 1998. To Join or Not to Join: Three Nordic Referendums on Membership in the European Union, Oslo: Scandinavian University Press.

Jones, E. 2018. Towards a theory of disintegration. European Journal of Public Policy, 25, 440-451.

Justice, High Court of 2016. R (Miller) v Secretary of State for Exiting the European Union. Summary of the judgment of the Divisional Court. Case No: CO/3809/2016 and CO/3281/2016. London: High Court of Justice, Queen's Bench Division, Divisional Court

Kobach, K. 1993. The theoretical role of the referendum. In: Kobach, K. (ed.) The Referendum: Direct Democracy in Switzerland. Yale University.

Kobach, K. 1994. Switzerland. In: Butler, D. \& Ranney, A. (eds.) Referendums around the world: the growing 
use of direct democracy. Washington D.C.: American Enterprise Institute for Public Policy Research.

Koole, K. \& Vis, B. 2012. Working Mothers and the State: Under Which Conditions do Governments Spend Much on Maternal Employment Supporting Policies? COMPASS Working Paper [Online].

Kriesi, H.P. 2006. Role of the Political Elite in Swiss Direct-Democratic Votes. Party Politics 12, 599-622.

Laursen, F. 2009. Denmark and the Ratification of the Lisbon Treaty: How a Referendum was avoided. Dalhousie EUCE Occasional Paper [Online]. Available: http://www.dal.ca/content/dam/ dalhousie/pdf/Diff/euce/pubs/Occasional_paper_7.pdf.

LeDuc, L. 2002. Referendums and elections: how do campaigns differ? In: Farrell, D. \& Schmitt-Beck, R. (eds.) Do Political Campaigns Matter? Campaign effects in elections and referendums. London: Routledge.

LeDuc, L. 2007. Opinion Formation and Change in Referendum. In: De Vreese, C. (ed.) The dynamics of referendum campaigns: an international perspective. Basingstoke: Palgrave MacMillan.

LeDuc, L. 2009. Campaign tactics and outcomes in referendums: a comparative analysis. In: Setälä, M. \& Schiller, T. (eds.) Referendums and Representative Democracy : Responsiveness, accountability and deliberation. New York: Routledge.

Lenowitz, J. 2015. 'A Trust that cannot be Delegated': The Invention of Ratification Referenda. American Political Science Review 109, 803-816.

Lewis-Beck, M.S. \& Paldam, M. 2000. Economic Voting: An Introduction. Electoral Studies 19, 113-121.

Lijphart, A. 1999. Patterns of Democracy, New Haven and London, Yale University Press.

Marsh, M. 2015. Voting on Europe, again and again: Stability and change in the Irish experience with EU referendums. Electoral Studies, 170-182.

Marxer, W. \& Pállinger, Z. 2009. Stabilizing or destabilizing? Direct-democratic instruments in different political systems. Referendums and Representative Democracy: Responsiveness, accountability and deliberation. London: Routledge.

Mason, R. 2017. House of Lords defeats government for second time on article 50 bill. The Guardian, 7 March 2017.

Massüger, N \& Kuoni, B. 2011. Viel Raum für Politik - die rechtlichen Grundlagen der nationalen EUReferenden. Zeitschrift für Staats- und Europawissenschaften, 131-155.

Maurice, E. 2017. Denmark clinches Europol ‘backdoor' deal. EU Observer, 1 May 2017.

Mello, P.A. 2014. Democratic Participation in Armed Conflict: Military Involvement in Kosovo, Afghanistan, and Iraq. , Basingstoke, Palgrave Macmillan.

Mendez, F, Mendez, M \& Triga, V 2014. Referendums and the European Union: A Comparative Inquiry, Cambridge, Cambridge University Press.

Mendez, F., Mendez, M. \& al., et 2017. Referendums on EU Matters. European Parliament. 
Meyer, C. et al. 2015. Design rules for successful governmental payments for ecosystem services: Taking agri-environmental measures in Germany as an example. Journal of Environmental Management 157, 146-159.

Miller, V. 2000. The Danish Referendum on Economic and Monetary Union. In: Library, House of Commons (ed.) Research Paper oo/78.

Monnet, J. 1978. Memoirs, New York, Doubleday \& Company, Inc.

Morel, L. 1996. France: towards a less controversial use of the referendum? In: Gallagher, M. \& Uleri, P. (eds.) The Referendum Experience in Europe. Basingstoke: MacMillan.

Morel, L. 2001. The Rise of Government-Initiated Referendums in Consolidated Democracies. In: Mendelsohn, M. \& Parkin, A. (eds.) Referendum Democracies. New York: Palgrave.

Morel, L. 2007. The Rise of 'Politically Obligatory' Referendums: The 2005 French Referendum in Comparative Perspective. West European Politics, 30, 1041-1067.

Morel, L. 2018a. The democratic criticism of referendums: The majority and true will of the people. In: Morel, L. \& Qvortrup, M. (eds.) The Routledge Handbook to Referendums and Direct Democracy. Abingdon: Routledge.

Morel, L. 2018b. Types of referendums, provisions and practice at the national level worldwide. In: Ovortrup, M. \& Morel, L. (eds.) The Routledge Handbook to Referendums and Direct Democracy. Abingdon: Routledge.

Nelsen, B.F. 1991. Norway and the European Community: On the Outside Moving In? European Community Studies Association Biennial Conference. George Mason University: Furman University.

Nijenhuis, H. 1992. Meerderheid tegen Verdrag van Maastricht; Denen zeggen nee, ook referendum in Frankrijk. NRC Handelsblad, 3 June 1992.

O’Donnell, S. 2017. EU Demands for Citizens ‘Ridiculously High,' U.K.'s Davis Says. Bloomberg, 30 May 2017.

O’Mahony, J. 2009. Ireland’s EU Referendum Experience. Irish Political Studies, 24, 429-446.

Oppermann, K. 2012. The Transnational Spillovers from Pledging EU Referendums: The Case of the European Constitution. In: Marxer, W. (ed.) Direct Democracy and Minorities. Wiesbaden: VS Verlag für Socialwissenschaften | Springer Fachmedien.

Oppermann, K. 2013a. The politics of avoiding referendums on the Treaty of Lisbon. Journal of European Integration, 35, 73-89.

Oppermann, K. 2013b. The politics of discretionary government commitments to European integration referendums. Journal of European Public Policy, 20, 684-701.

Oppermann, K. 2018. Derailing European Integration? Euroscepticism and the Politics of EU Referendums. In: Leruth, B., Startin, N. \& Usherwood, S. (eds.) The Routledge Handbook of Euroscepticism. Abingdon: Routledge.

Osborne, S. \& Broomfield, M. 2016. Switzerland waters down immigration referendum to protect EU 
relationship. Independent, 15 December 2016.

Pállinger, Z. 2017. The Hungarian Migrant Quota Referendum of 2016 in the Context of Hungarian Direct Democracy. In: Mendez, F. \& Mendez, M. (eds.) Referendums on EU matters. Brussels: European Parliament.

Papadopoulos, Y. 2001. How does direct democracy matter? The impact of referendum votes on politics and policy making. West European Politics, 24, 35-58.

Pelinka, A. \& Greiderer, S. 1996. Austria: the referendum as an instrument of internationalisation. In: Gallagher, M. \& Uleri, P. (eds.) The Referendum Experience in Europe. Basingstoke: MacMillan.

Persson, M. 2013. Ten years on, what Britain can learn from the Swedish euro referendum. The Guardian, 14 September 2013.

Petersen, N. 1998. The Danish Referendum on the Treaty of Amsterdam Europas. Discussion Paper. Bonn: Zentrum für Europäische Integrationsforschung, Rheinische Friedrich Wilhelms-Universität Bonn.

Popkin, S.L. 1991. The Reasoning Voter: Communication and Persuasion in Presidential Campaigns, Chicago, University of Chicago Press.

Poulsen, Kristian Ersb $\varnothing l l$ Berg \& Sander, Rasmus Christian Wolff. 2016. The Danish EC/EU referenda from 1972-2015 - A collective activity of thinking. International Public Administration and Politics Master thesis, Roskilde University.

Prosser, C. 2016. Calling European Union Treaty Referendums: Electoral and Institutional Politics. Political Studies, 64, 182-199.

PvdA 2006. Samen sterker Werken aan een beter Nederland. Electoral manifesto 2006.

Quinlan, S. 2012. The Lisbon Experience in Ireland: 'No' in 2008 but 'Yes' in 2009 - How and Why? Irish Political Studies, 27, 139-153.

Qvortrup, M. 2005. A Comparative Study of Referendums: Government by the People, Manchester, Manchester University Press.

Qvortrup, M. 2013. Direct democracy: A comparative study of the theory and practice of government by the people, Manchester, Manchester University Press.

Qvortrup, M. 2016. Referendums on Membership and European Integration 1972-2015. The Political Quarterly, 87, 61-68.

Qvortrup, M. 2018a. The history of referendums and direct democracy. In: Qvortrup, M. \& Morel, L. (eds.) The Routledge Handbook to Referendums and Direct Democracy. Abingdon: Routledge.

Qvortrup, M. 2018b. Picking winners: forecasting the results of EU referendums 1972-2016. In: Morel, L. \& Qvortrup, M. (eds.) The Routledge Handbook to Referendums and Direct Democracy. Abingdon: Routledge.

Raad van State 2004. Advies Nr. 37.804/AV. Wetsvoorstel houdende organisatie van een 
volksraadplegingover het verdrag tot instelling van een grondwet voor Europa. Belgische Kamer van Volksvertegenwoordigers, 29 november 2004.

Ragin, C. 2008. Redesigning Social Inquiry: Fuzzy Sets and Beyond., Chicago/London, University Press of Chicago.

Rankin, J., Henley, J., Oltermann, P. \& Smith, H. 2016. EU leaders call for UK to leave as soon as possible. The Guardian, 24 June 2016.

Rihoux, B. \& De Meur, G. 2009. "Crisp-Set Qualitative Comparative Analysis (csQCA)”. In: Rihoux, B. and Ragin, C. (ed.) Configurational Comparative Methods: Qualitative Comparative Analysis (QCA) and Related Techniques. London: SAGE.

Rihoux, B. \& Ragin, C. 2009. Configurational Comparative Methods: Qualitative Comparative Analysis (OCA) and Related Techniques, London, SAGE.

Rood, J., van Keulen, M. \& Limonard, B. 2008. De Europese Unie na het Verdrag van Lissabon, Den Haag, Nederlands Instituut voor Internationale Betrekkingen Clingendael.

Rose, R. 2018. Referendum challenges to the EU's policy legitimacy - and how the EU responds. Journal of European Public Policy, 1-20.

Rousseau, J.J. 1762. On the Social Contract; or, Principles of Political Rights Amsterdam, Marc-Michel Rey.

Ruin, O. 1996. Sweden: the referendum as an instrument for defusing political issues. The Referendum Experience in Europe. Basingstoke: MacMillan.

Ruth, S., Welp, Y. \& Whitehead, L. 2017. Let the People Rule? Direct Democracy in the Twenty-First Century, Colchester, ECPR Press.

Sattler, T. \& Urpelainen, J. 2012. Explaining Public Support for International Integration: How Do National Conditions and Treaty Characteristics Interact with Individual Beliefs? The Journal of Politics, 74, 1108-1124.

Schneider, C. \& Rohlfing, I. 2013. Combining OCA and Process Tracing in Set-Theoretic Multi-Method Research. Sociological Methods \& Research, 42, 559-597.

Schneider, C. \& Rohlfing, I. 2016. Case Studies Nested in Fuzzy-set OCA on Sufficiency: Formalizing Case Selection and Causal Inference. Sociological Methods \& Research, 45, 526-568.

Schneider, C. \& Wagemann, C. 2012. Set-Theoretic Methods: A User's Guide for Qualitative Comparative Analysis and Fuzzy Sets in Social Science, Cambridge, Cambridge University Press.

Schneider, G. 2018. Brinkmanship and backsliding: How governments deal with referendum decisions. In: Morel, L. \& Ovortrup, M. (eds.) The Routledge Handbook to Referendums and Direct Democracy. Abingdon: Routledge.

Schuck, A. 2009. Referendum Campaign Dynamics: News media, campaign effects and direct democracy. PhD Doctoral thesis, Universiteit van Amsterdam.

Schuck, A. \& De Vreese, C. 2015. Public support for referendums in Europe: A cross-national comparison in 
21 countries. Electoral Studies, 38, 149-158.

Sciarini, P. 2017. Direct Democracy in Switzerland: The Growing Tension Between Domestic and Foreign Politics. In: Ruth, S., Welp, Y. \& Whitehead, L. (eds.) Let the People Rule? Direct Democracy in the Twenty-First Century. Colchester: ECPR Press.

Seawright, J. \& Gerring, J. 2008. Case Selection Techniques in Case Study Research. A Menu of Qualitative and Quantitative Options. Political Research Quarterly, 61, 294-308.

Setälä, M. 1999. Referendums and Democratic Government: Normative Theory and the Analysis of Institutions, Basingstoke, MacMillan.

Setälä, M. \& Schiller, T. (eds.) 2009. Referendums and Representative Democracy: Responsiveness, Accountability and Deliberation, New York: Routledge.

Shu, M. 2008. Referendums and the Political Constitutionalisation of the EU. European Law Journal, 423445 .

Sitter, N. 2009. To structure political conflict: the institutionalization of referendums on European integration in the Nordic countries. In: Setälä, M. \& Schiller, Th. (ed.) Referendums and Representative Democracy: Responsiveness, accountability and deliberation. New York: Routledge.

Siune, K. \& Svensson, P. 1993. The Danes and The Maastricht Treaty: The Danish EC Referendum of June 1992. Electoral Studies, 12, 99-111.

Smith, J. 2016. David Cameron's EU renegotiation and referendum pledge: A case of déjà vu? British Politics, 11, 324-346.

Sparrow, A. 2016. MPs vote to demand Brexit plan and say article 50 should be triggered by end March - as it happened. The Guardian.

Statistics Sweden, Democracy Statistics 2010. EU and euro preferences in May 2010: Support for euro clearly down.

Steenbergen, M., Edwards, E. \& de Vries, C. 2007. Who's Cueing Whom? Mass-Elite Linkages and the Future of European Integration. European Union Politics, 8, 13-35.

Stokke, O.S. 2007. Qualitative comparative analysis, shaming, and international regime effectiveness. Journal of Business Research, 60, 501-511.

Suksi, M. 1996. Finland: the referendum as a dormant feature. In: Gallagher, M. \& Uleri, P. (eds.) The Referendum Experience in Europe. Basingstoke: MacMillan.

Svensson, P. 1996. Denmark: the referendum as minority protection. In: Gallagher, M. \& Uleri, P. (eds.) The Referendum Experience in Europe. Basingstoke: MacMillan.

Swissinfo.ch. 2016. Swiss extend free movement to Croatia after immigration vote. Swissinfo.ch, 16 December 2016.

Szabó, J. 2006. Norway and European integration: Prelude and consequences of the 1972 referendum. Öt 
Kontinens, 273-288.

Szczerbiak, A. \& Taggart, P. 2004. The politics of European referendum outcomes and turnout: two models. West European Politics, 27, 557-83.

Taylor, B. 2017. Election 2017: SNP manifesto calls for referendum 'at end of Brexit process'. BBC.

TheLocal.dk. 2017. Danish, EU parliaments agree on Europol deal. The Local DK, 28 April 2017.

Thomann, E. 2015. Customizing Europe: transposition as bottom-up implementation. Journal of European Public Policy, 22, 1368-1387.

Thomann, E. \& Magetti, M. 2017. Designing Research With Qualitative Comparative Analysis (OCA): Approaches, Challenges, and Tools. Sociological Methods \& Research, XX, 1-31.

Tierney, S. 2012. The Constitutional Referendum: The Theory and Practice of Republican Deliberation, Oxford, University Press.

Trechsel, A. \& Kriesi, H.P. 1996. Switzerland: the referendum and initiative as a centrepiece of the political system. In: Gallagher, M. \& Uleri, P. (eds.) The Referendum Experience in Europe. Basingstoke: MacMillan.

Tridimas, G. 2007. Ratification through referendum or parliamentary vote: When to call a non-required referendum? European Journal of Political Economy, 23, 674-692.

Tridimas, G. 2010. Referendum and the choice between monarchy and republic in Greece. Constitutional Political Economy, 21, 119-144.

Van Elsas, E. \& Van der Brug, W. 2015. The Changing Relationship between Left-right Ideology and Euroscepticism, 1973-2010. European Union Politics 16, 194-215.

Vandecasteele, B., Bossuyt, F. \& Orbie, J. 2015. A fuzzy-set qualitative comparative analysis of the Hungarian, Polish and Lithuanian presidencies and European Union Eastern partnership policies. European Politics and Society, 16, 556-580.

Vis, B. 2009. Governments and unpopular social policy reform: Biting the bullet or steering clear? European Journal of Political Research, 48, 31-57.

Vospernik, S. 2018a. Effects of referendums on party cohesion and cleavages: empirical findings from 21 EU countries. In: Morel, L. \& Ovortrup, M. (eds.) The Routledge Handbook to Referendums and Direct Democracy. Abingdon: Routledge.

Vospernik, S. 2018b. Referendums and consensus democracy: empirical findings from 21 EU countries. In: Morel, L. \& Qvortrup, M. (eds.) The Routledge Handbook to Referendums and Direct Democracy. Abingdon: Routledge.

Wagschal, U. 2007. Direktdemokratie und europäische Integration. In: Freitag, M. and Wagschal U. (ed.) Direkte Demokratie : Bestandsaufnahmen und Wirkungen im internationalen Vergleich. Berlin: Lit Verlag.

Widfeldt, A. 2004. Sweden. European Journal of Political Research, 43, 1144-1150. 
Williams, T. \& Gemperle, S.M. 2017. Sequence will tell! Integrating temporality into set-theoretic multimethod research combining comparative process tracing and qualitative comparative analysis. International Journal of Social Research Methodology, 20, 121-135.

Wimmel, A. 2014. The Impact of National Direct Democracy on the Choice for Convening EU Referendums. Perspectives on European Politics and Society 15, 33-50.

Ysmal, C. 2006. France. European Journal of Political Research, 45, 1105-1109. 


\section{Summary}

Referendums on European integration play a prominent role in the decision-making processes in current European democracies. Between 1972 and 2016, 61 EU-related referendums took place across 28 countries. The real breakthrough of the EU referendum occurred after the foundation of the European Union in 1992, after which three-quarters of the votes took place. The fact that in 46 out of 61 referendums the government won, demonstrates that overall governments have been quite successful in securing popular support for their EU policies. Within the increasing amount of literature on EU-related referendums, however, it has hardly been researched why governments sometimes win or lose. Therefore, the main research question this study addresses is: Under which conditions do governments win EU-related referendums?

Moreover, it is not clear if, how and why national governments have initiated such referendums, and how governments coped with defeated referendums. The so far 'permissive consensus' on European integration turned into a 'constraining dissensus' after the Danish 'No' to the Maastricht Treaty. This dissensus became most visible in referendums by which a majority of voters rejected the European policy as proposed by the government. In this way, the referendum has become a constraining device. Citizens in Norway and lastly in the UK have rejected membership of the EU, Swiss citizens rejected to join the European Economic Area, while and Danes and Swedes have prevented their countries to join the Eurozone. Citizens in France and The Netherlands blocked the completion of the ratification process of the Constitutional Treaty, while a majority of voters in Denmark and Ireland delayed the ratification process of the Treaties of Maastricht, Nice and Lisbon, respectively. More recently Greek and Hungarian voters expressed their dissent with the EU's proposed policies on the Eurozone and resettlement of migrants. Hence, the main research question is accompanied by two related questions: why do EU-related referendums take place and, how do governments deal with inconvenient referendum outcomes?

The study flows from embedding the referendum in representative democracy, the procedural and institutional settings of the referendums in European countries, to the analysis of the actual EU-related referendums themselves. The last part is dedicated to the impact of the failed referendum outcomes. An original dataset is used comprising all nationwide referendums directly related to the European integration process in European democratic countries, including referendums in non-EU member states such as in Liechtenstein, Norway and Switzerland.

\section{European referendums in historical perspective}

The entrance of referendums on European integration since 1972 should be located in the history of referendums in European countries covering more than two centuries. Since the French revolution of 1789, referendums have been introduced in Europe for three main reasons. First, referendums were called by (authoritarian) leaders in order to provide 
legitimacy to the decisions and constitutions of their regimes. Second, referendums were used to enforce the independence of new states. Third, referendums were introduced in many European states' new constitutional systems in response to the demand for more direct democratic participation by citizens. In all these states, even in Switzerland, the referendum is embedded in a representative system. Finally, the evolution of the European Union added a new dimension to the demand for referendums in European countries. The increasing transfer of powers from the member states to the EU implied that more frequently direct democratic decision-making was legally required or politically desired to legitimize this pooling of sovereignty.

\section{Calling referendums}

An overview and analysis provide in which countries EU-related referendums can be held, have been held, on what issues, and for which reasons they were triggered. First, the framework of referendum legislation across European democracies in the context of EU matters between 1970 and 2016 is analysed, unfolding the potential for EU-related referendums across Europe. A 'referendum trigger model' shows who can initiate referendums, distinguishing between mandatory and optional referendums. When comparing 43 current European democratic states, 39 countries provide regulations for referendums on European integration. 19 countries require mandatory referendums in case of constitutional amendments, and 11 countries do so in case of any (future) transfer of powers to or membership of international organisations such as the EU. In a handful of countries, the government can autonomously trigger an optional referendum. More often they are dependent on parliamentary approval and hence parliaments have much more opportunities to trigger EU-related referendums. To a lesser extent citizens can enforce popular initiatives.

Second, an inventory is made of which mandatory and optional referendums have been held and why. It could be that referendums are triggered by constitutional amendment, or that they are legally required due to a missing parliamentary majority. Alternatively the vote could have been triggered by governments to reinforce their power, to circumvent an opposing parliamentary majority, to underline the importance of the issue, and to resolve rifts within the government or within the governing parties. Also, parliaments could trigger referendums for reasons of appropriateness or for mediating motives. Finally, citizens can trigger a referendum on EU issues to either set the agenda or to recall a decision already taken by political elites.

The analysis shows that 19 of the 61 EU-related referendums were mandatory, and 42 were optional. Actually, half of all the EU-related referendums took place in only four countries: Switzerland (11), Ireland (9), Denmark (8) and France (3), as indicated in Figure S.1. There are three reasons for the limited practice in the other 24 countries. First, governments or parliaments felt no need to hold a referendum: the political actors considered referendums as a risk to block their European policy objectives. A second explanation is the limited potential for citizen-initiated referendums on EU matters: 11 out of 22 potential countries exclude 
citizen-initiated referendums on treaty ratification. A third reason for the limited practice are the hurdles to trigger the citizen-initiated referendums: the number of required signatures is rather high. Moreover, countries use turnout and/or approval quorums which pose additional thresholds on the validity of the result and hence on the envisaged effect of the referendum.

\section{Winning referendums}

The analysis reveals that governments won 46 out of 61 EU-related referendums. In order to understand why citizens support or reject European integration, scholars have been investigating referendum campaigns and factors that influence individual voting behaviour. While individual preferences may explain the effects of certain individual level causes, they do not explain the causes of an effect. Instead, this study takes another approach in order to explain referendum outcomes by means of reasoned policy-related variables on the aggregate level.

These explanatory patterns are to be inferred by the method and technique of fuzzy-set Qualitative Comparative Analysis (fsQCA). This method allows for the comparison of many cases and looks for combinations of conditions (i.e. factors) causing the outcome. It explores socio-economic and political-institutional conditions of variation across European democratic countries and examines the government's success. Four aggregate politicalinstitutional conditions (majority government, elite consensus, recent elections, and offensive referendum strategy), and two socio-economic conditions (economic prosperity, becoming an EU net recipient) have been identified that could explain government victory.

Within the population of cases, three types of EU-related referendums are distinguished: membership referendums, treaty referendums and policy referendums. This typology is well applicable in the framework of this study, because the distinction proves to be a meaningful contextual mediator which entails the different nature of the question that is at stake. The type of referendum matters in relation to the factors contributing to a successful referendum outcome.

The fsOCA analyses could correctly explain 44 out of 46 government victories and 14 out of 15 government defeats. It is shown that when the economy is booming and the government has a unified majority in parliament, governments almost always win. If the economy is deteriorating, however, the government only wins if it is only recently in office and backed by a wide consensus among elites. A unified majority government and economic development are the main drivers for winning referendums. The government hardly wins if both factors are absent. Hence, governments can utilise times of economic prosperity and political stability when holding referendums. When ratifying comprehensive EU treaties, an offensive referendum strategy by the government proves to be necessary to win, in most cases combined with economic prosperity. This implies that if the government is in a defensive position to hold a referendum on the ratification of such a treaty, it can hardly win.

The analysis of governments which lost referendums reveals that membership 
referendums are defeated when they feature the combination of a minority government which has been long in office, choosing a defensive referendum strategy and not being a prospective EU net recipient. Governments which have been long in office tend to lose treaty referendums in times of economic downturn. The reasons for losing policy referendums are less clear-cut and feature a defensive referendum strategy and elite polarisation, either in combination with a minority government, or in combination with economic downturn and a government whose honeymoon is over. In sum, the analyses show that the high number of government successes $(3 / 4)$ is strongly related to institutional advantages that governments possess over the opposition, in terms of their majority government, elite consensus and the time that they have been in office.

\section{Dealing with inconvenient referendum results}

How should a government deal with a defeated referendum? Although it seems that each overruled government had to invent its way out, a comparison of these 15 inconvenient referendum outcomes reveals that four main strategies have been followed. A first strategy is to accept the outcome. This strategy can take three forms: retaining the status quo, adaptation or renegotiation. For instance, the ratification failure of the Constitutional Treaty of 2005 resulted in the renegotiated Lisbon Treaty. A second strategy is to interpret the outcome, when there is no consensus how the referendum result should be implemented. There are no 'contingency plans' available and straight implementation or retaining the status quo would have serious consequences both for the EU and the country involved. Instead, such a situation demands creative interpretation skills from the government, as have been applied after the Brexit vote and the Dutch referendum on the EU-Ukraine Association Agreement in 2016. The third strategy is to circumvent the outcome by means of a second referendum on the issue, as was practiced after the Danish No to the Maastricht Treaty in 1992 and the Irish No to the Nice and Lisbon Treaties in 2001 and 2008. External pressures to hold such a second referendum to complete the treaty's ratification process, made that the first referendum proved less finally binding than it initially seemed. A fourth strategy to neglect the outcome was only deployed in Hungary's 2016 referendum on the EU's resettlement quota of migrants. The four strategies demonstrate that governments have been able to skilfully cope with inconvenient referendum outcomes. Referendums results are not irreversibly set once and for all.

\section{Implications}

This study improves our understanding of why EU-related referendums are held, under which conditions governments win or lose them, and how governments cope with the outcome. The results of the analyses provide guidance to governments' success in future EUrelated referendums in comparable circumstances. In this way it uniquely contributes to the development of government strategies knowing which circumstances have to be considered when an EU-related referendum is held. Research of EU-related referendums should take the 
strategic context in which these referendums take place (or in which they are avoided) into account. If it can be explained under which circumstances governments win or lose, this may influence the course and timing of future referendums during policy-making and ratification processes on European integration. The domestic and European level are so much interrelated, that the impact of a single -negative- vote is hardly the end of the decision-making process. As the deployed strategies how governments deal with inconvenient outcomes show, the referendum is rather the beginning of it. 


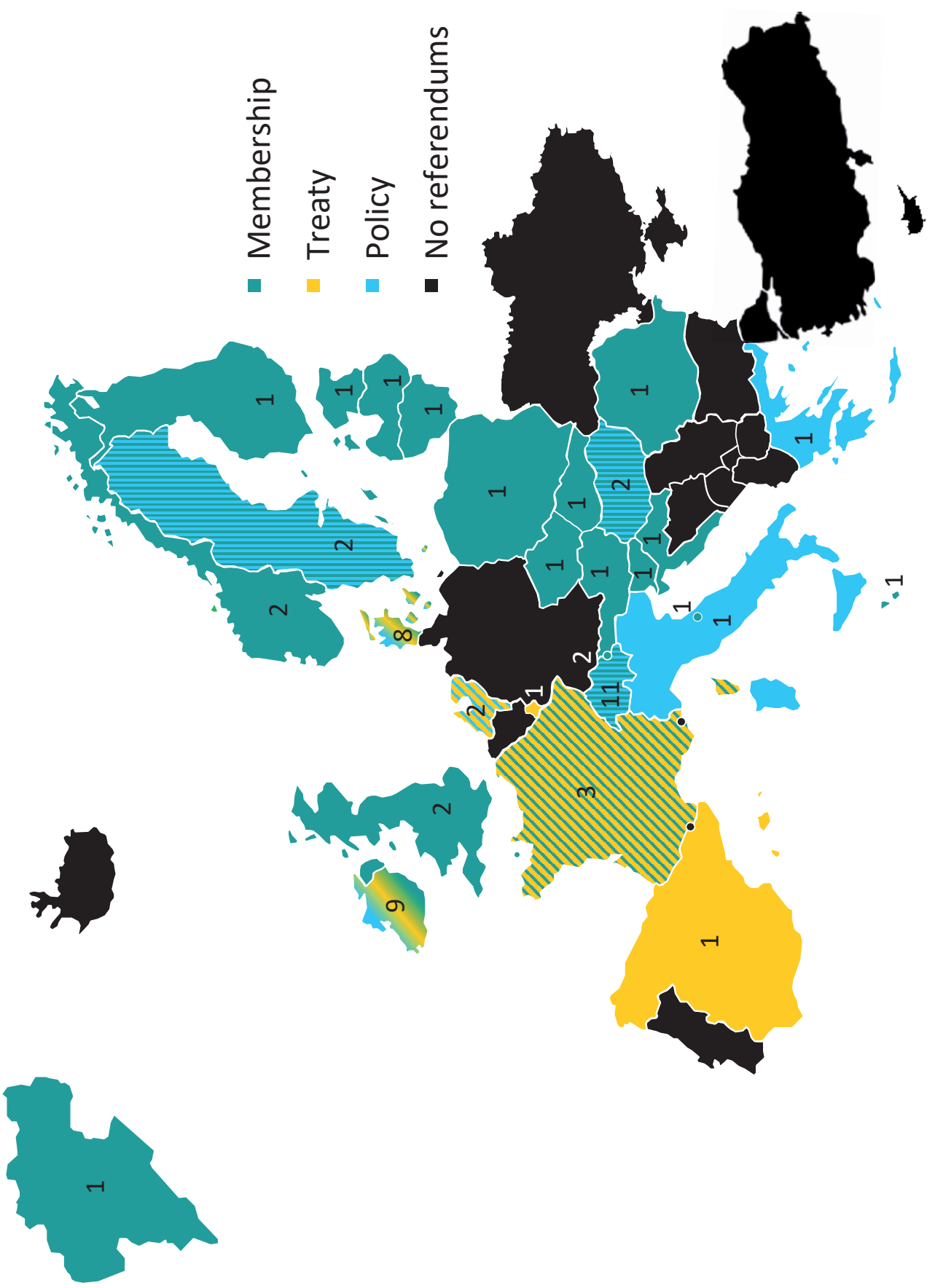

Figure S.1. Map of EU-related referendums 1972-2016, indicating type and number. 


\section{Samenvatting}

Referenda over Europese integratie spelen momenteel een prominente rol in het in het politieke besluitvormingsproces in Europese democratieën. Tussen 1972 en 2016 vonden 61 EU-gerelateerde referenda plaats in 28 verschillende landen. De doorbraak van het EUreferendum voltrok zich na de oprichting van de Europese Unie in 1992, waarna driekwart van de referenda plaatsvond. Het feit dat 46 van de 61 referenda werden gewonnen door de regering, laat zien dat in het algemeen regeringen redelijk succesvol zijn gebleken om steun van de bevolking voor hun EU beleid te verwerven. Binnen de groeiende literatuur over EU-gerelateerde referenda is amper onderzocht waarom regeringen soms winnen of verliezen. Zodoende luidt de voornaamste onderzoeksvraag van deze studie: Onder welke omstandigheden weten regeringen EU-gerelateerde referenda te winnen?

Daarnaast is het niet duidelijk of, hoe en waarom nationale regeringen dergelijke referenda hebben geïnitieerd en is evenmin onderzocht hoe regeringen omgingen met verloren referenda. De tot dan toe 'permissieve consensus' over Europese integratie kenterde naar een 'beperkende dissensus' na het Deense 'Nee' tegen het Verdrag van Maastricht. Deze onenigheid kwam het sterkst tot uitdrukking in referenda waarin een meerderheid van kiezers het door de regering voorgestelde Europese beleid verwierp. Zo werd het referendum een mechanisme dat de politieke speelruimte beperkt. Kiezers in Noorwegen en recentelijk in het Verenigd Koninkrijk verwierpen EU-lidmaatschap, Zwitsers weigerden lid te worden van de Europese Economische Ruimte, terwijl de Denen en Zweden wisten te verhinderen dat hun land zou toetreden tot de Eurozone. Franse en Nederlandse burgers blokkeerden de ratificatie van het Grondwettelijk Verdrag, terwijl een meerderheid van de kiezers in Denemarken en Ierland het ratificatieproces van het Verdrag van Maastricht, het Verdrag van Nice en het Verdrag van Lissabon respectievelijk vertraagde. Recentelijk keerden Griekse en Hongaarse kiezers zich tegen het voorgestelde EU-beleid over de Eurozone en de herverdeling van migranten. Zodoende gaat de voornaamste onderzoeksvraag gepaard met twee afgeleide vragen: waarom vinden EU-referenda plaats en, hoe gaan regeringen om met onwelgevallige referendumuitslagen?

De studie plaatst het referendum eerst binnen de representatieve democratie en volgt dan de procedurele en institutionele setting van referenda in Europese landen, waarna de analyse van de daadwerkelijk plaatsgevonden EU-gerelateerde referenda volgt. Het laatste deel is gewijd aan de impact van verloren referenda. Een originele dataset omvat alle landelijke referenda die direct aan het Europese integratieproces gerelateerd zijn, inclusief referenda in niet-EU-lidstaten zoals in Liechtenstein, Noorwegen en Zwitserland.

\section{Europese referenda in historisch perspectief}

De komst van referenda over Europese integratie sinds 1972 dient geplaatst te worden in de geschiedenis van referenda in Europese landen, die meer dan twee eeuwen omvat. Er zijn drie 
voornaamste redenen waarom referenda zijn geïntroduceerd in Europa na de Franse revolutie van 1789. Ten eerste werden referenda uitgeschreven door (autoritaire) leiders om legitimiteit aan hun besluiten en aan de grondwetten van hun regimes te ontlenen. Ten tweede werden referenda toegepast om onafhankelijkheid van nieuwe staten af te dwingen. Ten derde zijn referenda geïntroduceerd in grondwetten van vele nieuwe Europese staten, als reactie op de behoefte aan meer direct-democratische participatie door burgers. In al deze staten is het referendum ingebed in een representatief systeem, zelfs in Zwitserland. Bovendien voegde de ontwikkeling van de Europese Unie een nieuwe dimensie toe aan de vraag naar referenda in Europese landen. De groeiende overdracht van bevoegdheden van de lidstaten naar de EU impliceerde dat direct-democratische besluitvorming frequenter wettelijk noodzakelijk, dan wel politiek wenselijk geacht werd om het delen van soevereiniteit te legitimeren.

\section{Het uitschrijven van referenda}

Een overzicht en analyse laten zien in welke landen EU-gerelateerde referenda kunnen worden gehouden, welke zijn gehouden, waarover, en om welke redenen deze afgedwongen zijn. Allereerst volgt een analyse van het juridisch raamwerk van wetgeving over referenda in Europese landen in de context van EU-gerelateerde zaken tussen 1970 en 2016. Dit laat het potentieel voor EU-gerelateerde referenda over heel Europa zien. Een 'referendum trigger model' toont wie referenda kan initiëren, en maakt onderscheid tussen verplichte en optionele referenda (i.e. noodzakelijke en facultatieve referenda). Van de 43 huidige Europese democratische landen voorzien er 39 in wetgeving voor referenda over Europese integratie. Negentien landen vereisen een referendum in geval van amendering van de grondwet, terwijl 11 landen dit vereisen in geval van enige (toekomstige) overdracht van bevoegdheden aan of lidmaatschap van internationale organisaties zoals de EU. In een handvol landen kan de regering zelf een optioneel referendum teweegbrengen. Vaker zijn regeringen echter afhankelijk van parlementaire steun. Zodoende hebben parlementen veel meer mogelijkheden om EU-gerelateerde referenda af te dwingen. In beperktere mate kunnen burgers een volksinitiatief (referendum geïnitieerd door de bevolking) afdwingen.

Ten tweede wordt geïnventariseerd welke verplichte en optionele referenda zijn gehouden en waarom. Het kan zijn dat referenda worden afgedwongen door een grondwettelijk amendement, of dat ze wettelijk verplicht zijn vanwege een ontbrekende parlementaire meerderheid. Het referendum kan daarnaast ook getriggerd worden door regeringen om hun machtsbasis te vergroten, om een dwarsliggende parlementaire oppositie te omzeilen, om het belang van het onderwerp te onderstrepen, en om onenigheid binnen de regering of regeringspartijen op te lossen. Ook parlementen kunnen referenda triggeren aangezien zij dat gepast vinden of om interne verdeeldheid te maskeren. Tenslotte kunnen burgers een referendum triggeren over EU-issues om een punt op de publieke agenda te plaatsen of om een reeds genomen besluit van de politieke elite te herroepen.

De analyse toont dat 19 van de 61 EU-gerelateerde referenda verplicht waren, terwijl 42 
optioneel waren. De helft van al deze vond plaats in slechts vier landen: Zwitserland (11), Ierland (9), Denemarken (8) en Frankrijk (3), zoals aangeduid in Figuur S.1. Er zijn drie verklaringen voor deze beperkte toepassing in de 24 overige landen. Ten eerste was er voor regeringen en parlementen geen noodzaak om een referendum te houden: de politieke spelers beschouwden referenda als een risico die hun Europese beleidsdoelen kunnen blokkeren. Een tweede verklaring vormen de beperkte mogelijkheden voor door burgers geïnitieerde referenda over EU-onderwerpen: 11 van 22 potentiële landen sluiten immers door burgers geïnitieerde referenda over verdragsratificatie uit. Een derde reden voor de beperkte toepassing vormen de drempels om door burgers geïnitieerde referenda af te dwingen: het aantal vereiste handtekeningen is hoog. Daarnaast gebruiken landen opkomst- en of uitkomstquorums die een aanvullende drempel vormen voor de geldigheid van het resultaat en zodoende het voorziene effect van het referendum.

\section{Het winnen van referenda}

De analyse toont aan dat regeringen 46 van de 61 EU-gerelateerde referenda gewonnen hebben. Om te begrijpen waarom burgers Europese integratie ondersteunen dan wel verwerpen, hebben wetenschappers referendum campagnes onderzocht en andere factoren die individueel kiesgedrag beïnvloeden. Terwijl individuele voorkeuren het effect van bepaalde oorzaken op het individuele niveau kunnen verklaren, verklaren deze niet wat de oorzaken zijn van een bepaald effect. In plaats daarvan kiest deze studie voor een andere benadering door referendumuitkomsten door beredeneerde beleidsgerelateerde variabelen op het geaggregeerde niveau te verklaren. Deze verklarende patronen moeten worden onderkend via de methode en techniek van fuzzy-set Qualitative Comparative Analysis (kwalitatief vergelijkende analyse). Deze methode is geschikt voor de vergelijking van veel cases en zoekt naar combinaties van voorwaarden (i.e. factoren) die de uitkomst veroorzaken. Het verkent sociaal-economische en politiek-institutionele factoren van variatie in Europese democratische landen en onderzoekt daarin het succes van de regering. Vier geaggregeerde politiek-institutionele voorwaarden (meerderheidsregering, elite consensus, recente verkiezingen, en een offensieve referendumstrategie), en twee socioeconomische voorwaarden (economische voorspoed, het worden van EU netto-ontvanger) zijn geïdentificeerd die de winst van de regering zouden kunnen verklaren.

Binnen de populatie van cases kunnen drie typen van EU-gerelateerde referenda worden onderscheiden: lidmaatschapsreferenda, verdragsreferenda en beleidsreferenda. Deze classificatie is goed toe te passen binnen het raamwerk van dit onderzoek, aangezien het type referendum een betekenisvolle contextuele mediator vormt die het onderscheidende karakter van de verschillende vragen onderkent. Het type referendum doet er toe in relatie tot de factoren die bijdragen aan een succesvolle referendumuitkomst.

De fsOCA analyses kunnen 44 van de 46 overwinningen van de regering verklaren en 14 van de 15 nederlagen van de regering. Er wordt aangetoond dat wanneer de economie bloeit en 
de regering kan bogen op een eensgezinde parlementaire meerderheid, de regering bijna altijd wint. Wanneer de economie echter achteruitgaat, kan de regering alleen winnen wanneer zij pas kort in het zadel zit en gesteund wordt door een brede consensus tussen de elites. Een eensgezinde meerderheidsregering en economische ontwikkeling zijn zo de belangrijkste drijfveren om referenda te winnen. De regering kan amper winnen wanneer beide factoren afwezig zijn. Zodoende kunnen regeringen tijden van economische voorspoed en politieke stabiliteit benutten wanneer zij referenda houden. Wanneer de ratificatie van veelomvattende EU-verdragen aan de orde is, blijkt dat een offensieve referendumstrategie een noodzakelijke voorwaarde is om het referendum te winnen, veelal in combinatie met economische voorspoed. Dit impliceert dat wanneer de regering zich in een defensieve positie bevindt om een dergelijk verdragsreferendum te houden, zij amper kan winnen.

De analyse van regeringen die referenda verloren toont het volgende aan: lidmaatschapsreferenda worden verloren wanneer zij gepaard gaan met een combinatie van een minderheidsregering die lang op haar post zit, een defensieve referendumstrategie kiest en geen EU-netto-ontvanger is. Regeringen die lang in het zadel zitten, lijken verdragsreferenda te verliezen in tijden van economische tegenspoed. De oorzaken voor het verliezen van beleidsreferenda zijn minder scherp afgebakend en kenmerken een defensieve referendumstrategie en elite polarisatie, ofwel in combinatie met een minderheidsregering, ofwel in combinatie met economische tegenspoed en een regering wiens wittebroodsweken voorbij zijn. Kortom, de analyses laten zien dat het hoge aantal overwinningen van de regering (3/4) sterk is gerelateerd aan institutionele voordelen waarover regeringen beschikken, als het gaat om hun meerderheidsregering, elite consensus en de duur dat zij aan de macht zijn.

\section{Omgang met onwelgevallige referendumuitslagen}

Hoe moet een regering omgaan met een verloren referendum? Hoewel het erop lijkt dat elke overrulede regering haar eigen uitweg uit de impasse moest zien te vinden, laat een vergelijking van deze 15 onwelgevallige referendumuitslagen zien dat er vier verschillende strategieën gevolgd zijn. Een eerste strategie is om de uitkomst te accepteren. Deze strategie kan drie verschillende vormen aannemen: de status quo behouden, aanpassing of heronderhandeling. Het vastlopen van de ratificatie van het Grondwettelijk Verdrag in 2005 leidde bijvoorbeeld tot het heronderhandelde Verdrag van Lissabon. Een tweede strategie is om de uitkomst te interpreteren, wanneer er geen consensus is hoe de uitslag zou moeten worden geïmplementeerd. Er zijn geen 'rampenplannen' beschikbaar en de strikte implementatie of vasthouden aan de status quo zouden serieuze gevolgen hebben voor zowel de EU als het betrokken land zelf. In plaats daarvan vraagt zo'n situatie creatieve interpretatievaardigheden van de regering, zoals worden toegepast na het Brexit referendum en het Nederlandse referendum over het Associatieakkoord tussen de EU en Oekraïne in 2016. De derde strategie behelst het omzeilen van de uitslag door middel van een tweede referendum over hetzelfde onderwerp, zoals gebeurde na het Deense Nee bij het Verdrag van 
Maastricht in 1992 en het Ierse Nee tegen de Verdragen van Nice en Lissabon in 2001 en 2008. Externe druk om zo'n tweede referendum te houden om de verdragsratificatie te voltooien, maakte dat het eerste referendum minder bindend bleek dan het aanvankelijk leek. Een vierde strategie om de uitkomst te negeren is alleen toegepast bij het Hongaarse referendum over het EU quota over de herverdeling van migranten. De vier strategieën laten zien dat regeringen in staat zijn geweest om vaardig met onwelgevallige referendumuitslagen om te gaan. De uitslagen van referenda blijken niet voor altijd in beton gegoten.

\section{Implicaties}

Dit onderzoek draagt bij aan het begrip waarom EU-gerelateerde referenda gehouden worden, onder welke voorwaarden regeringen deze winnen of verliezen en hoe regeringen met de uitkomst omgaan. De resultaten van de analyse geven richting aan hoe regeringen bij toekomstige EU-gerelateerde referenda succesvol kunnen zijn in vergelijkbare omstandigheden. Op deze manier draagt het op een unieke manier bij aan de ontwikkeling van strategieën van de regering om te weten met welke omstandigheden rekening gehouden moet worden wanneer EU-gerelateerde referenda plaatsvinden. Onderzoek naar EU-gerelateerde referenda dient ook de strategische context waarin zulke referenda plaatsvinden (of waarin deze worden vermeden) te betrekken. Als verklaard kan worden onder welke omstandigheden regeringen winnen of verliezen, dan kan dit invloed hebben op het verloop en de timing van toekomstige referenda gedurende beleidsvorming over en ratificatieprocessen van Europese integratie. Het binnenlandse en Europese niveau zijn zo met elkaar verbonden, dat de impact van een enkele -negatieve- uitslag nog nauwelijks als het einde van het besluitvormingsproces betracht kan worden. Zoals de toegepaste strategieën over hoe regeringen omgaan met onwelgevallige uitslagen laten zien, is het referendum eerder het begin daarvan. 


\section{Appendices}

\section{Appendix Ch. 3: Constitutional and legal provisions}

\section{On Mandatory referendums}

\section{1 concerning Constitutional amendments}

Austria Art. 44 (3) Any total revision of the Federal Constitution shall upon conclusion of the procedure pursuant to Art. 42 above but before its authentication by the Federal President be submitted to a referendum by the entire nation, whereas any partial revision requires this only if one third of the members of the National Council or the Federal Council so demands

Andorra Art. 106. The revision of the Constitution shall require the approval of the General Council by a majority of two-thirds of the members of the Chamber. Immediately after its approval the proposal shall be submitted to ratification in a referendum; electoral law art. 67.

Denmark § 88: Should the Folketing pass a Bill for the purposes of a new constitutional provision, and the Government wish to proceed with the matter, writs shall be issued for the election of members of a new Folketing. If the Bill is passed unamended by the Folketing assembling after the election, the Bill shall, within six months after its final passage, be submitted to the electors for approval or rejection by direct voting. Rules for this voting shall be laid down by statute. If a majority of the persons taking part in the voting, and at least 40 per cent of the electorate, have voted in favour of the Bill as passed by the Folketing, and if the Bill receives the Royal Assent, it shall form an integral part of the Constitutional Act.

Estonia § 162. Chapter I "General Provisions" and Chapter XV "Amendment of the Constitution" of the Constitution may be amended only by a referendum.

$\$ 163$. The Constitution shall be amended by an Act which has been passed by: 1) a referendum; 2) two successive memberships of the Riigikogu; 3) the Riigikogu, as a matter of urgency....

$\S 164$. A three-fifths majority of the membership of the Riigikogu is required to submit a bill to amend the Constitution to a referendum.

France Art. 89. Referendums on amendments to the Constitution in accordance to Article 89 are mandatory unless the President decides to submit it to parliament convened in congress and parliament approves it by a 3/5 majority.

Ireland Art. 46. 2 Every proposal for an amendment of this Constitution shall be initiated in Dáil Éireann as a Bill, and shall upon having been passed or deemed to have been passed by both Houses of the Oireachtas, be submitted by Referendum to the decision of the 
people in accordance with the law for the time being in force relating to the Referendum.

Art. 47. 1. Every proposal for an amendment of this Constitution which is submitted by Referendum to the decision of the people shall, for the purpose of Article 46 of this Constitution, be held to have been approved by the people, if, upon having been so submitted, a majority of the votes cast at such Referendum shall have been cast in favour of its enactment into law.

Latvia Art. 77. If the Saeima has amended the first, second, third, fourth, sixth or seventy-seventh Article of the Constitution, such amendments, in order to come into force as law, shall be submitted to a national referendum;

Lithuania Art. 148. The provision of Article 1 of the Constitution "the State of Lithuania shall be an independent democratic republic" may only be altered by referendum if not less than 3/4 of the citizens of Lithuania with the electoral right vote in favour thereof. The provisions of the First Chapter "The State of Lithuania" and the Fourteenth Chapter "Alteration of the Constitution" may be altered only by referendum.

Law on Referendum 2002 (v.2012) Art. 4. 1. Referendums shall be mandatory with regard to the following issues: 1) on the amendment to the provision of Article 1 of the Constitution of the Republic of Lithuania that, "the State of Lithuania shall be an independent and democratic republic;" 2) on the amendment to the provisions of Chapter I of the Constitution of the Republic of Lithuania, "the State of Lithuania;" 3) on the amendment to the provisions of Chapter XIV of the Republic of Lithuania Constitution, "Amending the Constitution;" 4) on the amendment to the Constitutional Act, dated June 8, 1992, "On Non-Alignment of the Republic of Lithuania to Post-Soviet Eastern Alliances;" ... 2. Mandatory referendums may be held also with regard to other laws or provisions thereof, which 300 thousand citizens having the right to vote or the Seimas shall submit a proposal for to be decided by means of a referendum.

Malta Art. 66 (3) In so far as it alters - (a) this sub-article or sub-article (4) of this article; or (b) sub-article (2) of article 76 of this Constitution, a bill for an Act of Parliament under this article shall not be presented to the President for his assent unless not less than three nor more than six months after its passage through the House in the manner specified in sub-article (2) of this article it has been submitted to the electors qualified to vote for the election of members of the House of Representatives and the majority of the electors voting have approved the bill.

Montenegro Art 157. Change of Articles 1, 2, 3, 4, 12, 13, 15, 45 and 157 shall be final if minimum three fifths of all the voters support the change in the national referendum.

Law on Referendum (2001): Art. 37. The decision in a referendum is taken by a majority vote of the citizens who have voted, provided that the majority of citizens with voting rights has voted.

Romania Art. 151. 3 The revision shall be final after the approval by a referendum held within 30 days of the date of passing the draft or proposal of revision. 
San Marino Art. 3bis and 17: Revision of Declaration if there is an absolute parliamentary majority, but no two-thirds majority.

Serbia Art. 203. The National Assembly shall be obliged to put forward the act on amending the Constitution in the republic referendum to have it endorsed, in cases when the amendment of the Constitution pertains to the preamble or principles of the Constitution, human and minority rights and freedoms, the system of authority, proclamation the state of war and emergency, derogation from human and minority rights in the state of emergency or war or the proceedings of amending the Constitution. ... The amendment to the Constitution shall be adopted if the majority of voters who participated in the referendum voted in favour of the amendment.

Spain Art. 168. 1. If a total revision of the Constitution is proposed, or a partial revision thereof, affecting the Preliminary Title, Chapter Two, Section 1 of Title I, or Title II, the principle shall be approved by a two-thirds majority of the members of each House, and the Cortes shall immediately be dissolved. 2. The Houses elected must ratify the decision and proceed to examine the new Constitutional text, which must be approved by a two-thirds majority of the members of both Houses. 3. Once the amendment has been passed by the Cortes Generales, it shall be submitted to ratification by referendum.

Switzerland Art. 140. 1 The following must be put to the vote of the People and the Cantons: a. amendments to the Federal Constitution; ...

2. The following are submitted to a vote of the People: a. popular initiatives for a total revision of the Federal Constitution; ... b. popular initiatives for a partial revision of the Federal Constitution in the form of a general proposal that have been rejected by the Federal Assembly; c. the question of whether a total revision of the Federal Constitution should be carried out, in the event that there is disagreement between the two Councils.

Turkey: if a constitutional amendment is adopted by a $3 / 5$ but not $2 / 3$ majority of MPs and not sent back by the President for reconsideration.

Ukraine Art. 156. A draft law on introducing amendments to Chapter I "General Principles," Chapter III — "Elections. Referendum," and Chapter XIII — "Introducing Amendments to the Constitution of Ukraine," is submitted to the Verkhovna Rada of Ukraine by the President of Ukraine, or by no less than two-thirds of the constitutional composition of the Verkhovna Rada of Ukraine, and on the condition that it is adopted by no less than twothirds of the constitutional composition of the Verkhovna Rada of Ukraine, and is approved by an All-Ukrainian referendum designated by the President of Ukraine.

Art. 73. Issues of altering the territory of Ukraine are resolved exclusively by an All-Ukrainian referendum.

Law on Referendums: Art. 13. The Verkhovna Rada of Ukraine shall call All-Ukrainian referendum 1) on questions of approval or abolition of the Constitution of Ukraine as well as on questions of pre-termination of the Verkhovna Rada and the President of Ukraine, in case 
it shall be demanded by not less than three million of citizens of Ukraine, who have the right to participate in a referendum; 2) on questions of approval or abolishing of the Constitution of Ukraine or other legislative acts of Ukraine, which, according to this Law may be submitted to All-Ukrainian referendum, except questions on the pre-term termination of the authorities of the Verkhovna Rada and the President of Ukraine, if this shall be demanded by not less than one-half of peoples' deputies of Ukraine.

\section{2 concerning Treaty ratification, transfer of powers and joining international organisations}

Croatia Art. 142. A procedure entailing the association of the Republic of Croatia into alliances with other states may be initiated by at least one-third of the deputies of the Croatian Parliament, the President of the Republic and the Government of the Republic of the Croatia... Any decision concerning the association of the Republic of Croatia shall be made in a referendum by a majority vote of all voters voting in the referendum.

Denmark $\$ 20$ (1). Powers that are granted to the authorities of the Kingdom under this Constitution may, by means of an Act and to a specific extent, be transferred to international authorities created by mutual agreement with other States to promote international legal order and cooperation.

(2). A majority of five-sixths of the Members of Parliament is required to pass Bills in this respect. If such a majority is not obtained, but the majority required to pass normal Bills is obtained, and the Government maintains the Bill, it is submitted to the parliamentary electors for approval or rejection in accordance with the rules established for referendums in Section 42.

France Art. 88.5: Any Government Bill authorizing the ratification of a treaty pertaining to the accession of a state to the European Union shall be submitted to referendum by the President of the Republic. Notwithstanding the foregoing, by passing a motion adopted in identical terms in each House by a three-fifths majority, Parliament may authorize the passing of the Bill according to the procedure provided for in paragraph three of article 89 .

Hungary [ex] Art. 79. A binding referendum shall be held on the accession of the Republic of Hungary to the European Union pursuant to the Accession Treaty. The date of this referendum shall be 12 April 2003. The question to be put in the referendum shall be: "Do you agree that the Republic of Hungary should become a Member of the European Union?"

Latvia Art. 68(3). Membership of Latvia in the European Union shall be decided by a national referendum, which is proposed by the Saeima. Substantial changes in the terms regarding the membership of Latvia in the European Union shall be decided by a national referendum if such referendum is requested by at least one-half of the members of the Saeima.

Art. 79. (...) A draft law, decision regarding membership of Latvia in the European Union or substantial changes in the terms regarding such membership submitted for national 
referendum shall be deemed adopted if the number of voters is at least half of the number of electors as participated in the previous Saeima election and if the majority has voted in favour of the draft law, membership of Latvia in the European Union or substantial changes in the terms regarding such membership.

Lithuania Law on Referendum 2002 (v.2012) Art. 4.1. Referendums shall be mandatory with regard to the following issues: ... 5) regarding participation by the Republic of Lithuania in international organizations, should this participation be linked with the partial transfer of the scope of competence of Government bodies to the institutions of international organizations or the jurisdiction thereof. Required 30\% abs. approval and 50\% turnout (designed for EU accession) Law on Referendum 2003: 50\% turnout and simple majority requirement* [decision by parliament to hold EU accession referendum was based on this].

Macedonia Art. 120. A proposal for entering/joining a union or community with other states, or for dissociation from a union or community with other states, may be submitted by the President of the Republic, the Government or by at least 40 Representatives. ... A decision of association with, or dissociation from, a union or community is adopted if it is upheld in a referendum by the majority of the total number of voters in the Republic.

Switzerland Art. 140. 1 The following must be put to the vote of the People and the Cantons: b. accession to organisations for collective security or to supranational communities [since 1999];

Art. 141 Implementation of international treaties. 1 If the decision on ratification of an international treaty is subject to a mandatory referendum, the Federal Assembly may incorporate in the decision on ratification the amendments to the Constitution that provide for the implementation of the treaty.

\section{Switzerland Constitution 1874 (in force until 1977) Art. 89 (as amended in 1920)}

(1) Federal law and federal decrees must be approved by both Councils

(2) Federal laws and generally binding federal decrees must be submitted to the people for approval or rejection if 30,000 Swiss citizens entitled to vote or eight Cantons so demand.

(3) Treaties with foreign countries, which are open-ended or concluded for a period of more than fifteen years, should also be submitted to the people for approval or rejection, if 30,000 Swiss citizens entitled to vote or eight Cantons so demand.

From 1977-1999: (2) ...50,000 Swiss citizens entitled to vote or eight Cantons so demand. (3) Paragraph (2) shall be applicable also to international treaties which: a) are of unspecified duration and cannot be denounced; b) provide for adherence to an international organization; c) entail a multilateral unification of the law. (4) By a decision of both Houses Paragraph (2) shall be applicable to other treaties. (5) Adherence to collective security organizations or to supranational bodies shall be submitted to the vote of the people and the Cantons. 
Slovakia Art. 7. (1) The Slovak Republic may enter into a state union with other states upon its free decision. The decision on entering into a state union with other states, or on withdrawal from this union, shall be made by a constitutional law which must be confirmed by a referendum.

Art. 7 4. (2) The Slovak Republic may, by an international treaty ratified and promulgated in a manner laid down by law, or on the basis of such treaty, transfer the exercise of a part of its rights to the European Communities and European Union. Legally binding acts of the European Communities and European Union shall have primacy over the laws of the Slovak Republic. Undertaking of legally binding acts that require implementation shall be executed by law or a government ordinance pursuant to Article 120, paragraph 2. (4) In order for any international treaties on human rights and fundamental freedoms, international political treaties, international treaties of military nature, international treaties establishing the membership of the Slovak Republic in international organizations, international economic treaties of general nature, international treaties whose execution requires a law and international treaties which directly constitute rights or obligations of natural persons or legal persons to be valid, an approval of the National Council of the Slovak Republic is required prior to their ratification. As amended by Constitutional Law No. 90/2001.

United Kingdom 2011 European Union Act. Sections 2, 3, 4 and 6:

The Act distinguishes between the ordinary revision of the EU Treaties, the simplified revision procedure according to Article 48(6) TEU, or other specific EU decisions. http://www. legislation.gov.uk/ukpga/2011/12/pdfs/ukpga_20110012_en.pdf.

\section{On Optional referendums}

\section{1 concerning Issues of national importance}

Albania Art. 150. 1. The people, through 50,000 citizens entitled to vote, have the right to a referendum for the abrogation of a law, and to request the President of the Republic to call a referendum on issues of special importance. 2. The Assembly, on the proposal of not less than one-fifth of the deputies or on the proposal of the Council of Ministers, can decide that an issue or a draft law of special importance be submitted to referendum. 3. Principles and procedures for conducting a referendum, and its validity, are provided by law.

Art. 152. 1. Within 60 days, the Constitutional Court reviews preliminarily the constitutionality of the issues submitted to referendum according to art. 150, par. 1 and 2, art. 151, par. 2 and 3, and art. 177, par. 4 and 5. 2. The importance of the special issues contemplated in paragraphs 1 and 2 of article 150 is not subject to adjudication by the Constitutional Court. 3. The President of the Republic sets the date of the referendum within 45 days after the announcement of a positive decision of the Constitutional Court or after the expiration of the period within which the Constitutional Court should have rendered its decision. During the year, referenda can be held on only one day. 
Andorra Art. 76. The Head of Government, with the approval of the majority of the General Council, may request the Coprinces to call a referendum on political matters.

Austria Art. 43. If the National Council so resolves or if the majority of members of the National Council so demands, every enactment of the National Council shall be submitted to a referendum upon conclusion of the procedure pursuant to Art. 42 above but before its authentication by the Federal President.

Art. 45. (1) For a referendum the absolute majority of the validly cast votes is decisive.

Bulgaria Issues within the competence of the Grand National Assembly such as the territory of Bulgaria and treaties providing changes thereof are excluded.

Art. 84. The National Assembly shall exercise the following powers: ...5. pass resolution on the holding of a national referendum;

Croatia Art. 87. The Croatian Parliament may call a referendum on proposals to amend the Constitution, a bill or any such other issue as may fall within its purview. The President of the Republic may, at the proposal of the Governmentand with the countersignature of the Prime Minister, call a referendum on a proposal to amend the Constitution or any such other issue as he/she may deem to be of importance to the independence, integrity and existence of the Republic of Croatia. The Croatian Parliament shall call referenda on the issues specified in paragraphs (1) and (2) of this Article in accordance with law, when so requested by ten percent of the total electorate of the Republic of Croatia. At such referenda, decisions shall be made by a majority of voters taking part therein. Decisions made at referenda shall be binding. A law shall be adopted on any such referendum. Such law may also stipulate the conditions for holding a consultative referendum.

Denmark §42: (1) Where a Bill has been passed by the Folketing, one-third of the members of the Folketing may, within three weekdays from the final passing of the Bill, request of the President that the Bill be submitted to a referendum. Such request shall be made in writing and signed by the members making the request. ...

(5) At the referendum votes shall be cast for or against the Bill. For the Bill to be rejected, a majority of the electors who vote and not less than thirty per cent of all persons who are entitled to vote, shall have voted against the Bill.

(6) ... Bills introduced for the purpose of discharging existing treaty obligations shall not be submitted to decision by referendum.

(7) ... Where, under the rules of sub-section (1), one-third of the members of the Folketing request a referendum on the Bill or on the Act to which the Royal Assent has been given, such referendum shall be held in accordance with the above rules. Where the Act is rejected by the referendum an announcement to that effect shall be made by the Prime Minister without undue delay, and not later than fourteen days after the referendum was held. From the date of such announcement the Act shall become ineffective. (8) Rules for referenda, including the extent to which referenda shall be held in the Faroe Islands and in Greenland, shall be laid down by statute. 
Estonia § 105. The Riigikogu has the right to submit a bill or other national issue to a referendum. The decision of the people shall be made by a majority of the participants in the voting... The decision of the referendum shall be binding on all state institutions. If a bill which is submitted to a referendum does not receive a majority of votes in favour, the President of the Republic shall declare extraordinary elections to the Riigikogu.

$\S 106$. Issues regarding the budget, taxation, financial obligations of the state, ratification and denunciation of international treaties, the declaration or termination of a state of emergency, or national defence shall not be submitted to a referendum. The procedure for holding a referendum shall be provided by the Referendum Act.

Finland Art. 53 (ex 22a) - Referendum and citizens' initiative (new title, 1112/2011, entry into force 1.3.2012) The decision to organise a consultative referendum is made by an Act, which shall contain provisions on the time of the referendum and on the choices to be presented to the voters. Provisions concerning the conduct of a referendum are laid down by an Act. At least fifty thousand Finnish citizens entitled to vote have the right to submit an initiative for the enactment of an Act to the Parliament, as provided by an Act. | Act on the Procedure on Consultative Referenda 571/1987: The most extensive and important reforms came in 1987, when provisions on the holding of consultative referendums were added to the Constitution.

Special law on EU membership: 578/1994: Act on a consultative referendum concerning the question whether Finland should join the European Union. Initiatives can only address issues that Parliament has the power to address. For instance, international treaties cannot be the subject of initiatives.

Greece Art. 44(2). The President of the Republic shall by decree proclaim a referendum on crucial national matters following a resolution voted by an absolute majority of the total number of Members of Parliament, taken upon proposal of the Cabinet. A referendum on Bills passed by Parliament regulating important social matters, with the exception of the fiscal ones, shall be proclaimed by decree by the President of the Republic, if this is decided by three-fifths of the total number of its members, following a proposal of two-fifths of the total number of its members, and as the Standing Orders and the law for the application of the present paragraph provide. (...)

Hungary Art. 8. 1. Parliament shall order a national referendum upon the motion of at least 200,000 electors. Parliament may order a national referendum upon the motion of the President of the Republic, the Government or one hundred thousand electors. The decision made by any valid and conclusive referendum shall be binding on Parliament. 2 . National referenda may be held about any matter within Parliament's responsibilities and competences. 3. No national referendum may be held on: a. any matter aimed at the amendment of the Fundamental Law, (...) d. any obligation arising from an international agreement (...) 4. A national referendum shall be valid if more than half of all electors have cast a valid vote, and shall be conclusive if more than half of all voters casting a valid vote 
have given the same answer to a question.

Iceland Art. 26. If the president refuses to sign a bill. Act on the Conduct of Referendums. 2010 No. 91. Art. 1. If the Althingi resolves that a general secret referendum is to be held on a particular matter or draft legislation, it shall be held in accordance with this Act. The outcome of such a referendum shall have advisory value.

Ireland Art. 27. This Article applies to any Bill, other than a Bill expressed to be a Bill containing a proposal for the amendment of this Constitution, which shall have been deemed, by virtue of Article 23 hereof, to have been passed by both Houses of the Oireachtas. 1. A majority of the members of Seanad Éireann and not less than one-third of the members of Dáil Éireann may by a joint petition addressed to the President by them under this Article request the President to decline to sign and promulgate as a law any Bill to which this article applies on the ground that the Bill contains a proposal of such national importance that the will of the people thereon ought to be ascertained. (...) 5.1) In every case in which the President decides that a Bill the subject of a petition under this Article contains a proposal of such national importance that the will of the people thereon ought to be ascertained, he shall inform the Taoiseach and the Chairman of each House of the Oireachtas accordingly in writing under his hand and Seal and shall decline to sign and promulgate such Bill as a law unless and until the proposal shall have been approved either: i) by the people at a Referendum in accordance with the provisions of section 2 of Article 47 of this Constitution within a period of eighteen months from the date of the President's decision, or ii) by a resolution of Dáil Éireann passed within the said period after a dissolution and re-assembly of Dáil Éireann.

Art. 47. 2. $1^{\circ}$ Every proposal, other than a proposal to amend the Constitution, which is submitted by Referendum to the decision of the people shall be held to have been vetoed by the people if a majority of the votes cast at such Referendum shall have been cast against its enactment into law and if the votes so cast against its enactment into law shall have amounted to not less than thirty-three and one-third per cent of the voters on the register.

Italy Art. 71 (...) The people may initiate legislation by proposing a bill drawn up in sections and signed by at least fifty-thousand voters.

Art 75. A general referendum may be held to repeal, in whole or in part, a law or a measure having the force of law, when so requested by five hundred thousand voters or five Regional Councils. No referendum may be held on a law regulating taxes, the budget, amnesty or pardon, or a law ratifying an international treaty. (...) The referendum shall be considered to have been carried if the majority of those eligible has voted and a majority of valid votes has been achieved. The procedures for conducting a referendum shall be established by law.

Latvia Art. 72. (...) The President shall suspend the proclamation of a law if so requested by not less than one-third of the members of the Saeima. This right may be exercised by the President, or by one-third of the members of the Saeima, within ten days of the adoption of the law by the Saeima. The law thus suspended shall be put to a national referendum if so requested by not less than one-tenth of the electorate (...). A national 
referendum shall not take place, however, if the Saeima again votes on the law and not less than three-quarters of all members of the Saeima vote for the adoption of the law.

Art 73. The Budget and laws concerning loans, taxes, customs duties, railroad tariffs, military conscription, declaration and commencement of war, peace treaties, declaration of a state of emergency and its termination, mobilisation and demobilisation, as well as agreements with other nations may not be submitted to national referendum.

Art. 74. A law adopted by the Saeima and suspended pursuant to the procedures specified in Article seventy-two shall be repealed by national referendum if the number of voters is at least half of the number of electors as participated in the previous Saeima election and if the majority has voted for repeal of the law.

Art. 78. Electors, in number comprising not less than one tenth of the electorate, have the right to submit a fully elaborated draft of an amendment to the Constitution or of a law to the President, who shall present it to the Saeima. If the Saeima does not adopt it without change as to its content, it shall then be submitted to national referendum.

Liechtenstein Art. 66. 1) Every law passed by Parliament that it does not declare to be urgent (...) shall be subject to a popular vote if Parliament so decides or if at least 1,000 Liechtenstein citizens eligible to vote or at least three municipalities submit a request to that effect, in the manner provided for in article 64, within 30 days of the official announcement of the resolution of Parliament.

Lithuania Art. 9 The most significant issues concerning the life of the State and the Nation shall be decided by referendum. In the cases established by law, the Seimas shall announce a referendum. A referendum shall also be announced if not less than 300,000 citizens with the electoral right so request. The procedure for the announcement and execution of a referendum shall be established by law.

Art. 67 The Seimas: ... 3) shall adopt resolutions on referendums;

Macedonia Art. 73. The Assembly decides on calling a referendum concerning specific matters within its sphere of competence by a majority vote of the total number of Representatives. The decision is passed in a referendum if a majority of those voting have cast in favour of the same, on condition that more than half of the total number of voters voted. The Assembly is obliged to call a referendum if one is proposed by at least 150,000 voters. The decision made in a referendum is binding.

Malta Referenda Act 1973 (v.2012). Art. 13. (1) Any provision of any enactment, whether enacted before or after the coming into force of this Part, and not being an enactment listed in sub article (2), shall have effect and continue to have effect subject to the provisions of this Part of this Act.

(2) The provisions of this Part of this Act shall not apply to this article and to the following enactments: $(a)$ the Constitution and any regulation made under any provision thereof; $(b)$ 
the European Convention Act; (c) any law providing for the matters referred to in article 56(8) $(a),(b)$ or $(c)$ of the Constitution; $(d)$ the Interpretation Act; $(e)$ the General Elections Act; $(f)$ any fiscal legislation; $(g)$ any legislation giving effect to any treaty obligation undertaken by Malta; and ( $h$ ) save as provided in article 36A of the Local Councils Act, any bye-law made by any local council under the said Act.

Art. 14. (1) Any number of persons registered as voters for the election of members of the House of Representatives, being not less than ten per cent of the total number of persons registered as voters (...), may by signing a declaration in the form set out in the First Schedule demand that the question whether one or more provisions of an enactment to which this Part applies, shall not continue in force, shall be put to those entitled to vote in a referendum under this Act.

Montenegro Art. 93. (...) The proposal to call for the national referendum may be submitted by: at least 25 Members of the Parliament, the President of Montenegro, the Government or at least $10 \%$ of the citizens with the right to vote.

Law on Referendum (2001) Art. 3. The republican referendum can be called for the purpose obtaining an opinion of citizens prior to making a decision on specific issues lying within the competence of the Assembly of the Republic.

Netherlands Advisory Referendum Act 2015: 300,000 citizens may call for a consultative referendum on bills, except those dealing with the Constitution, the monarchy or the budget.

Poland Art. 125. A nationwide referendum may be held in respect of matters of particular importance to the State. The right to order a nationwide referendum shall be vested in the Sejm, to be taken by an absolute majority of votes in the presence of at least half of the statutory number of Deputies, or in the President of the Republic with the consent of the Senate given by an absolute majority vote taken in the presence of at least half of the statutory number of Senators. A result of a nationwide referendum shall be binding, if more than half of the number of those having the right to vote have participated in it.

The validity of a nationwide referendum and the referendum referred to in Article 235, para. 6 , shall be determined by the Supreme Court. The principles of and procedures for the holding of a referendum shall be specified by statute.

Portugal Art. 115. 3. The object of a referendum shall be limited to important issues concerning the national interest upon which the Assembly of the Republic or the Government must decide by passing an international agreement or by passing legislation. (...) 5. The provisions of the previous paragraph shall not prejudice the submission to referendum of such important issues concerning the national interest as should be the object of an international agreement pursuant to Article 161i, except when they concern peace or the rectification of borders.

Romania Art. 90. The President of Romania may, after consultation with Parliament, 
ask the people of Romania to express, by referendum, their will on matters of national interest.

Law on Organization and Conduct of the Referendum, art. 12. specifies issues that may be considered issues of national interest. However, the president can also call a referendum on issues which are not specified in Article 12. Presidential Decree 1507/2009, which cites Article 11(1) \& 11(2) of the Referendum Law as a legal basis, calls a referendum on an issue not explicitly specified by Article 12.

Art. 74: (2) A legislative initiative of the citizens may not touch on matters concerning taxation, international affairs, amnesty or pardon.

San Marino Law 101/1994. 'Recall' referendum means (partial) recalling existing laws. 'Confirmative' referendum can be invoked by a parliamentary majority for 'constitutional bills' on any matter, except for tax and financial matters, amnesty and pardon.

Serbia Art. 108. Upon the request of the majority of all deputies or at least 100,000 voters, the National Assembly shall call the referendum on issues falling within its competence, in accordance with the Constitution and Law.

Slovakia Art. 93. (...) 2) A referendum can be used to decide also on other important issues of public interest. 3) Basic rights and freedoms, taxes, levies and the state budget may not be the subject of a referendum.

Art. 95 (1) The referendum is called by the President of the Slovak Republic if requested by a petition signed by a minimum of 350,000 citizens, or on the basis of a resolution of the National Council of the Slovak Republic, within 30 days after the receipt of the citizens' petition, or the resolution of the National Council of the Slovak Republic.

Art. 96 (1) The motion to pass a resolution of the National Council of the Slovak Republic on calling a referendum may be introduced by Members of Parliament, or by the Government of the Slovak Republic.

(2) A referendum shall be held within 90 days from the day it was called by the President of the Slovak Republic.

Art. 98. (1) The results of the referendum are valid if more than one-half of eligible voters participated in it and if the decision was endorsed by more than one half of the participants in the referendum.

Slovenia Art. 90. SI (2013). The National Assembly shall call a referendum on the entry into force of a law that it has adopted if so required by at least forty thousand voters. A referendum may not be called: (...) on laws on the ratification of treaties; (...) A law is rejected in a referendum if a majority of voters who have cast valid votes vote against the law, provided at least one fifth of all qualified voters have voted against the law. Referendums are regulated by a law passed in the National Assembly by a two-thirds majority vote of deputies present. ${ }^{*}$ As amended by the Constitutional Act Amending Articles 90, 97, and 99 of the Constitution 
of the Republic of Slovenia, which was adopted on 24 May 2013 and entered into force on 31 May 2013 (Official Gazette of the Republic of Slovenia No. 47/13). The original text of Article 90 read as follows:

"The National Assembly may call a referendum on any issue which is the subject of regulation by law. The National Assembly is bound by the result of such referendum. The National Assembly may call a referendum from the preceding paragraph on its own initiative, however it must call such referendum if so required by at least one third of the deputies, by the National Council or by forty thousand voters. (...) A proposal is passed in a referendum if a majority of those voting have cast votes in favour of the same. Referendums are regulated by a law passed in the National Assembly by a two-thirds majority vote of deputies present."

Spain Art. 92. 1. Political decisions of special importance may be submitted to all citizens in a consultative referendum. 2. The referendum shall be called by the King at the proposal of the President of the Government, following authorisation by the Congress of Deputies. 3. An organic law shall regulate the terms and procedures for the different kinds of referendum provided for in this Constitution.

Art. 87 3. An organic law shall establish the manner in which popular initiative in connection with the submitting of non-governmental bills shall be regulated, as well as the requirements therefore. In any case, no fewer than 500,000 authenticated signatures shall be required. This initiative may not touch on matters concerning organic law, taxation, international affairs or the prerogative of granting pardons.

Sweden Ch.8 (Art.2). Provisions concerning the following shall be adopted by means of an act of law: (...) 5 . the holding of a consultative referendum throughout the Realm and the procedure for holding a referendum on a matter of fundamental law

-Law No. 1994:1064: http://www.riksdagen.se/sv/Dokument-Lagar/Lagar/

Svenskforfattningssamling/sfs_sfs-1994-1064/

-Law No. 2003:83: http://www.riksdagen.se/sv/Dokument-Lagar/Lagar/

Svenskforfattningssamling/sfs_sfs-2003-83/

Switzerland Art. 141. 1. If within 100 days of the official publication of the enactment any 50,000 persons eligible to vote or any eight Cantons request it, the following shall be submitted to a vote of the People: a. federal acts; b. emergency federal acts whose term of validity exceeds one year; $\mathrm{c}$. federal decrees, provided the Constitution or an act so requires; $\mathrm{d}$. international treaties that: 1 . are of unlimited duration and may not be terminated; 2. provide for accession to an international organisation; 3.contain important legislative provisions or whose implementation requires the enactment of federal legislation.

Ukraine Art. 72. An All-Ukrainian referendum is designated by the Verkhovna Rada of Ukraine or by the President of Ukraine, in accordance with their authority established by this Constitution. An All-Ukrainian referendum is called on popular initiative on the request of no less than three million citizens of Ukraine who have the right to vote, on the condition 
that the signatures in favour of designating the referendum have been collected in no less than two-thirds of the oblasts, with no less than 100 ooo signatures in each oblast.

Art. 74. A referendum shall not be permitted in regard to draft laws on issues of taxes, the budget and amnesty.

Law of Ukraine on all-Ukrainian and local referendums. Art. 5. Questions attributed by the Constitution of Ukraine to Ukrainian jurisdiction can be submitted to All-Ukrainian referendum. Questions on realization of Ukrainian people's right to self-determination and joining federative or confederative state formations, as well as leaving them may be submitted to All-Ukrainian referendum only. Questions attributed by legislation of Ukraine to a Court or Prosecutor's jurisdiction shall be not submitted to All-Ukrainian referendum, amnesty and pardon questions, as well as questions of extraordinary and urgent steps .taken by State bodies of Ukraine to protect public order, health and security of citizens also may not be submitted to All-Ukrainian referendum. Questions related to the election, appointment and exemption of officials under the jurisdiction of the Verkhovna Rada, the President and Cabinet of Ministries of Ukraine shall not be submitted to the mentioned referendum as well.

Art. 12. All-Ukrainian referenda shall be called by the Verkhovna Rada of Peoples' deputies.

Art. 46. Advisory Questioning of Citizens of Ukraine. (Consultative Referendum). With the purpose to reveal the citizens' will, when important issues of the national and local significance are to be resolved, the All-Ukrainian and local advisory questioning of citizens of Ukraine (consultative referendum) can be conducted according to procedures stipulated by this Law. The results of the advisory questioning shall be considered and taken into account when decisions are adopted by the appropriate state bodies. If drafts of laws and other decisions of the Verkhovna Rada of Ukraine or decisions of the local Council of peoples' deputies do not correspond with the results of the All-Ukrainian or an appropriate local advisory questioning, such laws, decisions could be adopted only by the majority of no less than two-thirds of all peoples' deputies of Ukraine or deputies of an appropriate local Council of peoples' deputies. (...)

United Kingdom Political Parties, Elections and Referendums Act. Art. 101 (1) Subject to the following provisions of this section, this Part applies to any referendum held throughout - (a)the United Kingdom; (...) (2) In this Part - (a) "referendum" means a referendum or other poll held, in pursuance of any provision made by or under an Act of Parliament, on one or more questions specified in or in accordance with any such provision; 


\section{2 concerning Constitutional amendments}

Albania Art. 177 4. The Assembly may decide, by two-thirds of all its members, that the proposed constitutional amendments be voted on in a referendum. The proposed constitutional amendment becomes effective after ratification by referendum, which takes place not later than 60 days after its approval by the Assembly. 5. An approved constitutional amendment is submitted to referendum when one-fifth of the members of the Assembly request it.

Austria Art. 44 (3) Any total revision of the Federal Constitution shall upon conclusion of the procedure pursuant to Art. 42 above but before its authentication by the Federal President be submitted to a referendum by the entire nation, whereas any partial revision requires this only if one third of the members of the National Council or the Federal Council so demands.

Italy Art.138. Laws amending the Constitution and other constitutional laws shall be adopted by each House after two successive debates at intervals of not less than three months, and shall be approved by an absolute majority of the members of each House in the second voting. Said laws are submitted to a popular referendum when, within three months of their publication, such request is made by one-fifth of the members of a House or five hundred thousand voters or five Regional Councils. The law submitted to referendum shall not be promulgated if not approved by a majority of valid votes.

A referendum shall not be held if the law has been approved in the second voting by each of the Houses by a majority of two-thirds of the members.

Latvia Law on National Referendums, Initiation of Laws and European Citizens' Initiative*. Art. 1 A national referendum shall be held if: (...) 4) the Saeima has not adopted without changes in its contents a draft law or a draft amendment to the Constitution submitted by not fewer than one-tenth of the electorate

Liechtenstein Art. 66 (see 1) above] 2) If the resolution concerns the Constitution as a whole or individual parts thereof, the request must be made by at least 1,500 Liechtenstein citizens eligible to vote or by at least four municipalities.

Luxembourg Art. 114. Any revision of the Constitution must be adopted in the same terms by the Chamber of Deputies in two successive votes, separated by an interval of at least three months. No revision will be adopted if it has not obtained at least two-thirds of the votes of the members of the Chamber; votes by proxy will not be admitted. The text adopted in the first reading by the Chamber of Deputies is submitted to a referendum, which substitutes for the second vote of the Chamber, if in the two months following the first vote demand for it is made[,] either by more than a quarter of the members of the Chamber, or by twenty-five thousand electors inscribed in the electoral lists for legislative elections. The revision can only be adopted if it receives the majority of the valid suffrage expressed. The law governs the modalities of organization of the referendum. 
Poland Art. 235. (...) 6. If a bill to amend the Constitution relates to the provisions of Chapters I, II or XII, the subjects specified in para. 1 above may require, within 45 days of the adoption of the bill by the Senate, the holding of a confirmatory referendum.

Serbia Art. 203. A proposal to amend the Constitution may be submitted by at least one third of the total number of deputies, the President of the Republic, the Government and at least 150,000 voters. (...) The National Assembly shall adopt an act on amending the Constitution by a two-third majority of the total number of deputies and may decide to have it endorsed in the republic referendum by the citizens.

Slovenia Art. 168: (1) A proposal to initiate the procedure for amending the Constitution may be made by twenty deputies of the National Assembly, the Government or at least thirty thousand voters. (2) Such proposal is decided upon by the National Assembly by a two-thirds majority vote of deputies present.

Art. 170. (1) The National Assembly must submit a proposed constitutional amendment to voters for adoption in a referendum, if so required by at least thirty deputies.

Spain Art. 167 3. Once the amendment has been passed by the Cortes Generales, it shall be submitted to ratification by referendum, if so requested by one tenth of the members of either House within fifteen days after its passage.

Sweden Ch. 8, Art. 16. A referendum shall be held on a proposal concerning fundamental law which is held in abeyance over an election, on a motion to this effect by at least one tenth of the members, provided at least one third of the members vote in favour of the motion. (...) The referendum shall be held simultaneously with the election referred to in Article 14. (...). The proposal is rejected if a majority of those taking part in the referendum vote against it, and if the number of those voting against exceeds half the number of those who registered a valid vote in the election. In other cases the proposal goes forward to the Riksdag for final consideration.

Switzerland Art. 138. 1. Any 100,000 persons eligible to vote may within 18 months of the official publication of their initiative propose a total revision of the Federal Constitution. 2. This proposal must be submitted to a vote of the People.

Art. 139. 1. Any 100,000 persons eligible to vote may within 18 months of the official publication of their initiative request a partial revision of the Federal Constitution. 2. A popular initiative for the partial revision of the Federal Constitution may take the form of a general proposal or of a specific draft of the provisions proposed. 3 . If the initiative fails to comply with the requirements of consistency of form, and of subject matter, or if it infringes mandatory provisions of international law, the Federal Assembly shall declare it to be invalid in whole or in part. 4. If the Federal Assembly is in agreement with an initiative in the form of a general proposal, it shall draft the partial revision on the basis of the initiative and submit it to the vote of the People and the Cantons. If the Federal Assembly rejects the initiative, it shall submit it to a vote of the People; the People shall decide whether the initiative should be 
adopted. If they vote in favour, the Federal Assembly shall draft the corresponding bill. 5. An initiative in the form of a specific draft shall be submitted to the vote of the People and the Cantons. The Federal Assembly shall recommend whether the initiative should be adopted or rejected. It may submit a counter-proposal to the initiative.

Art. $139 b$ 1. The People vote on the initiative and the counter-proposal at the same time. 2. The People may vote in favour of both proposals. In response to the third question, they may indicate the proposal that they prefer if both are accepted. 3. If in response to the third question one proposal to amend the Constitution receives more votes from the People and the other more votes from the Cantons, the proposal that comes into force is that which achieves the higher sum if the percentage of votes of the People and the percentage of votes of the Cantons in the third question are added together.

Turkey Art. 175. (...) If the Assembly adopts the draft law referred by the President by a two-thirds majority, the President may submit the law to referendum. (...) A law on the Constitutional amendment adopted by a two-thirds majority of the total number of members of the Turkish Grand National Assembly directly or if referred back by the President for further consideration, or its articles as considered necessary may be submitted to a referendum by the President. (...) The Turkish Grand National Assembly, in adopting the laws related to the Constitutional amendment, shall also decide on which provisions shall be submitted to referendum together and which shall be submitted individually.

Ukraine Law of Ukraine on all-Ukrainian and local referendums. Art. 3. The subjectmatter of All-Ukrainian referendum can be: confirmation of the Constitution of Ukraine, its separate provisions, as well as introduction of changes and amendments to the Constitution of Ukraine; adoption, change or cancellation of Laws of Ukraine or their separate provisions; adoption of decisions which determine the principal content of the Constitution of Ukraine, Laws of Ukraine, and other legislative Acts.

Art. 13 Calling of Referenda on Citizens of Ukraine and People Deputies' demand. The Verkhovna Rada of Ukraine shall call All-Ukrainian referendum 1) on questions of approval or abolition of the Constitution of Ukraine (...), in case it shall be demanded by not less than three million of citizens of Ukraine, who have the right to participate in a referendum; 2) on questions of approval or abolishing of the Constitution of Ukraine or other legislative acts of Ukraine, which, according to this Law may be submitted to All-Ukrainian referendum, except questions on the pre-term termination of the authorities of the Verkhovna Rada and the President of Ukraine, if this shall be demanded by not less than one-half of peoples' deputies of Ukraine.

\section{3 concerning Treaty ratification, transfer of powers and joining international organisations}

Bulgaria Art. 9 (4). Referendums related to international agreements concluded by 
the Republic of Bulgaria can be hold prior to their ratification.

Czech Republic Art.10a (1) Certain powers of Czech Republic authorities may be transferred by treaty to an international organization or institution. (2) The ratification of a treaty under paragraph 1 requires the consent of Parliament, unless a constitutional act provides that such ratification requires the approval obtained in a referendum.

Art. 39 (4) The concurrence of three-fifths of all Deputies and three-fifths of all Senators present is required for the adoption of a constitutional act or for giving assent to the ratification of treaties referred to in Article 10a para. 1.

Art. 62 (1) The President of the Republic...l) shall call a referendum on the Czech Republic's accession to the European Union and declare the result thereof.

Art. 87 (1) The Constitutional Court has jurisdiction: [added by the referendum] m) to determine whether the manner in which a referendum on the Czech Republic's accession to the European Union was held is in harmony with the Constitutional Act on the Referendum on the Czech Republic's Accession to the European Union and with the statute issued in implementation thereof.

France Art. 11 [added > 2008] The President of the Republic may, on a recommendation from the Government when Parliament is in session, or on a joint motion of the two Houses, published in the Journal Officiel, submit to a referendum any Government Bill which deals with the organization of the public authorities, or with reforms relating to the economic, social or environmental policy of the Nation, and to the public services contributing thereto, or which provides for authorization to ratify a treaty which, although not contrary to the Constitution, would affect the functioning of the institutions. Where the referendum is held on the recommendation of the Government, the latter shall make a statement before each House and the same shall be followed by a debate.

A referendum concerning a subject mentioned in the first paragraph may be held upon the initiative of one fifth of the Members of Parliament, supported by one tenth of the voters enrolled on the electoral register. This initiative shall take the form of a Private Member's Bill and shall not be applied to the repeal of a statutory provision promulgated for less than one year. The conditions by which it is introduced and those according to which the Constitutional Council monitors the respect of the provisions of the previous paragraph, are set down by an Institutional Act.

If the Private Member's Bill has not been considered by the two Houses within a period set by the Institutional Act, the President of the Republic shall submit it to a referendum. Where the decision of the French people in the referendum is not favourable to the Private Member's Bill, no new referendum proposal on the same subject may be submitted before the end of a period of two years following the date of the vote. Where the outcome of the referendum is favourable to the Government Bill or to the Private Member's Bill, the President of the Republic shall promulgate the resulting statute within fifteen days following the proclamation of the 
results of the vote.

Liechtenstein Art. 66bis: 1) Every resolution of Parliament concerning assent to an international treaty (article 8) shall be subject to a popular vote if Parliament so decides or if at least 1,500 Liechtenstein citizens eligible to vote or at least four municipalities submit a request to that effect, in the manner provided for in article 64 , within 30 days of the official announcement of the resolution of Parliament. Landesgesetzblatt 1922 No. 27.

Luxembourg Art. 51 7. The electors may be called to decide by way of referendum in the cases and under the conditions to be determined by the law.

Netherlands Advisory Referendum Act includes laws on the ratification of referendums.

Consultative Referendum Act European Constitution 2005 (in force 2005-2008).

Poland Art. 90. The Republic of Poland may, by virtue of international agreements, delegate to an international organization or international institution the competence of organs of State authority in relation to certain matters. (...) Granting of consent for ratification of such agreement may also be passed by a nationwide referendum in accordance with the provisions of Article 125. Any resolution in respect of the choice of procedure for granting consent to ratification shall be taken by the Sejm by an absolute majority vote taken in the presence of at least half of the statutory number of Deputies.

Portugal [current]. Art. 115 (...) 4. The following shall not be subject to referendum (...) c) The matters provided for in Article 161, without prejudice to the provisions of the following paragraph; d) The matters provided for in Article 164, save the provisions of subparagraph i).

5. The provisions of the previous paragraph shall not prejudice the submission to referendum of such important issues concerning the national interest as should be the object of an international agreement pursuant to Article 161i, except when they concern peace or the rectification of borders.

Art. 161. The Assembly ofthe Republic shall beresponsiblefor:(...) i) Passing treaties, particularly those that entail Portugal's participation in international organisations, friendship, peace, defence, the rectification of borders or military affairs, as well as international agreements.

Slovenia Art. 3a [>2003]. Pursuant to a treaty ratified by the National Assembly by a two-thirds majority vote of all deputies, Slovenia may transfer the exercise of part of its sovereign rights to international organisations which are based on respect for human rights and fundamental freedoms, democracy, and the principles of the rule of law and may enter into a defensive alliance with states which are based on respect for these values. Before ratifying a treaty referred to in the preceding paragraph, the National Assembly may call a referendum. A proposal is passed in the referendum if a majority of voters who have cast valid votes vote in favour of the same. The National Assembly is bound by the result of 
such referendum. If such referendum has been held, a referendum regarding the law on the ratification of the treaty concerned may not be called.

Switzerland Art. 141. 1. If within 100 days of the official publication of the enactment any 50,000 persons eligible to vote or any eight Cantons request it, the following shall be submitted to a vote of the People: (...) d. international treaties that: 1 . are of unlimited duration and may not be terminated; 2. provide for accession to an international organisation; 3. contain important legislative provisions or whose implementation requires the enactment of federal legislation.

International treaties that do not fall under the criteria specified in Articles 140-141 of the constitution are approved by a simple federal decree (Art. 24, Federal Act on Parliament), which are not subject to a referendum (Art. 163).

Art. $141 a$ Implementation of international treaties. (...) 2 If the decision on ratification of an international treaty is subject to an optional referendum, the Federal Assembly may incorporate in the decision on ratification the amendments to the law that provide for the implementation of the treaty.

\section{On Excluded referendums}

Austria Art. 41(2). The popular initiative should concern a matter regulated by federal law and can be provided in the form of a legislative proposal.

Bulgaria 2009 Act Art. 9(2) the following issues may not be decided through a national referendum: 1. The issues within the jurisdiction of the Grand National Assembly; 2. The issues referred to in art. 84, $\$ 4,6,7,8,10,12,16$ and 17, Art. 91, 91a, Art. 103 (2), Art. 130 (3), Art. 132 and Art. 147 (1) of the Constitution; 3. Taxes, labour and social security payments and contributions; 4 . The state budget; 5 . Internal rules of organization and operation of the National Assembly. 6. Codes and laws which govern the whole matter in a given area.

Estonia § 106. Issues regarding the budget, taxation, financial obligations of the state, ratification and denunciation of international treaties, the declaration or termination of a state of emergency, or national defence shall not be submitted to a referendum.

Hungary Art. 8 (2011). Article 8 3. No national referendum may be held on:

a. any matter aimed at the amendment of the Fundamental Law, $d$. any obligation arising from an international agreement, $h$. the declaration of a state of war, state of national crisis and state of emergency, and on the declaration or extension of a state of preventive defence, i. any matter related to participation in military operations.

Italy Art. 75 (...) No referendum may be held on a law regulating taxes, the budget, amnesty or pardon, or a law ratifying an international treaty. 
Latvia Art. 73. ... peace treaties ...as well as agreements with other nations may not be submitted to national referendum.

Netherlands: Advisory Referendum Act 2015. Art. 5d. No referendum may be held on: (...) d. laws to change the Constitution (...); e. laws that seek only the implementation of treaties or decisions of international organizations (...)

Portugal [<1989, (art. 115 ex 118)] art. 118.2. The referendum cannot relate to matters of national interest that should be decided by Parliament or the Government through approval of an international convention or legislative act.

[>1989] Art. 115 (...) 4. The following shall not be subject to referendum: a) Alterations to this Constitution;

b) Issues and acts with a budgetary, tax-related or financial content; c) The matters provided for in Article 161, without prejudice to the provisions of the following paragraph; d) The matters provided for in Article 164, save the provisions of subparagraph i). 5 . The provisions of the previous paragraph shall not prejudice the submission to referendum of such important issues concerning the national interest as should be the object of an international agreement pursuant to Article 161i, except when they concern peace or the rectification of borders.

Romania Art. 74. Legislative initiative. (2) A legislative initiative of the citizens may not touch on matters concerning taxation, international affairs, amnesty or pardon.

San Marino: Law 101/1994 Art. 3 "parimenti escluso il Referendum abrogativo su leggi o atti aventi forza di legge (...) nonché di ratifica di convenzioni e trattati internazionali."

Slovenia: Art. 90* (Legislative Referendum) A referendum may not be called: (...) on laws on the ratification of treaties; *As amended by the Constitutional Act Amending Articles 90, 97, and 99 of the Constitution of the Republic of Slovenia, which was adopted on 24 May 2013.

Spain Art. 87. This initiative may not touch on matters concerning organic law, taxation, international affairs or the prerogative of granting pardons.

United Kingdom Political Parties, Elections and Referendums Act (2000). Art. 101 (2). In this Part- (a) "referendum" means a referendum or other poll held, in pursuance of any provision made by or under an Act of Parliament, on one or more questions specified in or in accordance with any such provision. 


\section{Appendix Ch. 4: Supplementary tables}

Table A4.1. Raw data ( $\mathrm{n}=61)$ per referendum type.

Membership referendums $(\mathrm{n}=27)$.
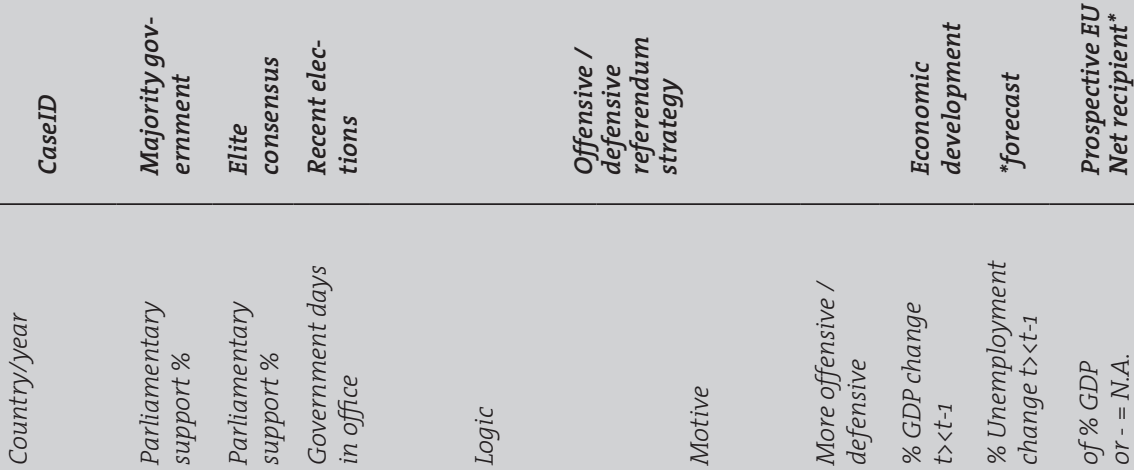

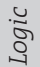
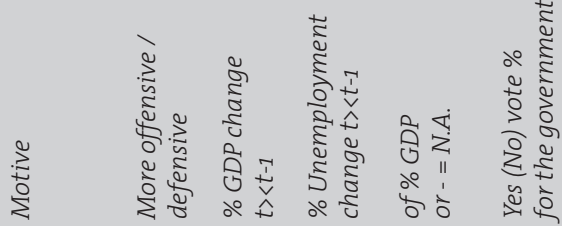

\begin{tabular}{llllllllllll}
\hline AUS1994 & 0.765 & 0.77 & 1273 & Constitutionality & Mandatory & OFF & 1.9 & -0.1 & -0.44 & 66.6 \\
\hline CRO2012 & 0.536 & 0.99 & 30 & Constitutionality & Mandatory & OFF & -2 & 1.3 & 0.24 & 66.7 \\
\hline CZE2003 & 0.505 & 0.8 & 333 & Constitutionality & Mandatory & OFF & 1.7 & 0.5 & 0.30 & 77.3 &
\end{tabular}

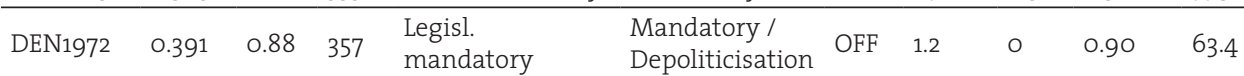

\begin{tabular}{lllllllllll}
\hline EST2003 & 0.594 & 0.72 & 157 & Constitutionality & Mandatory & OFF & 1.2 & -0.3 & 1.57 & 66.8
\end{tabular}

\begin{tabular}{lllllllllll}
\hline FIN1994 & 0.535 & 0.78 & 1269 & Partisan & Mediation & DEF & 4.5 & 0.2 & -0.10 & 56.9 \\
\hline
\end{tabular}

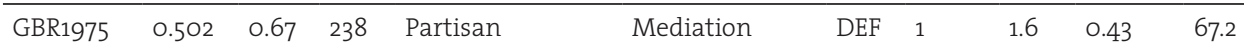

\begin{tabular}{llllllllllll}
\hline GBR2016 & 0.29 & 0.74 & 412 & Partisan & Mediation & DEF & -0.1 & -0.6 & -0.46 & 48.1 \\
\hline
\end{tabular}

$\begin{array}{llllllllllll}\text { GRE1982 } & 0.619 & 0.62 & 1029 & \text { Partisan } & \begin{array}{l}\text { Power } \\ \text { reinforcing }\end{array} & \text { OFF } & -5.1 & 1.7 & 0.60^{* *} & 53\end{array}$

\begin{tabular}{lllllllllll}
\hline HUN2003 & 0.513 & 1 & 320 & Appropriateness & Policy seeking & OFF & -0.4 & -0.4 & 0.24 & 83.7 \\
\hline IRL1972 & 0.521 & 0.87 & 1043 & Constitutionality & Mandatory & OFF & 3 & -1.5 & 2.66 & 83.1
\end{tabular}

\begin{tabular}{lllllllllll} 
IRL1972 & 0.521 & 0.87 & 1043 & Constitutionality & Mandatory & OFF & 3 & -1.5 & 2.66 & 83.1 \\
\hline LAT2003 & 0.55 & 1 & 317 & Constitutionality & Mandatory & OFF & 0.7 & -1.4 & 1.72 & 67 \\
\hline LIE1992 & 1 & 1 & 1299 & Appropriateness & Policy seeking & OFF & 1.8 & 0 & - & 55.8 \\
\hline LIE1995 & 1 & 1 & 480 & Appropriateness & Policy seeking & OFF & -1 & 0 & - & 55.9 \\
\hline LIT2003 & 0.525 & 1 & 125 & Appropriateness & Policy seeking & OFF & 3.3 & -1.4 & 2.06 & 91.1 \\
\hline MAL2003 & 0.538 & 0.54 & 1644 & Partisan & $\begin{array}{l}\text { Power } \\
\text { reinforcing }\end{array}$ & OFF & -2.7 & 0.3 & 0.93 & 53.6 \\
\hline NOR1972 & 0.493 & 0.53 & 558 & Partisan & Mediation & DEF & -0.3 & 0.2 & - & 46.5 \\
\hline NOR1994 & 0.406 & 0.43 & 441 & Partisan / appr. & $\begin{array}{l}\text { Mediation / } \\
\text { Policy seeking }\end{array}$ & DEF & 2.3 & -0.6 & - & 47.7 \\
\hline POL2003 & 0.561 & 0.78 & 596 & Appropriateness & Policy seeking & OFF & 2.5 & -0.3 & 0.72 & 77.5 \\
\hline ROM2003 & 0.449 & 0.7 & 1033 & Constitutionality & Mandatory & OFF & 0.1 & -1.4 & 0.49 & 89.4 \\
\hline SLK2003 & 0.52 & 0.83 & 212 & Appropriateness & Policy seeking & OFF & 0.2 & -1.1 & 0.51 & 92.5 \\
\hline SLO2003 & 0.644 & 0.96 & 843 & Appropriateness & Policy seeking & OFF & -0.9 & 0.4 & 0.40 & 89.6 \\
\hline SMR2013 & 0.583 & 0.52 & 343 & Constitutionality & $\begin{array}{l}\text { Popular initia- } \\
\text { tive }\end{array}$ & DEF & 0.5 & -0.5 & - & 50.3 \\
\hline
\end{tabular}




\begin{tabular}{lllllllllll}
\hline SWE1994 & 0.461 & 0.54 & 38 & Partisan & Mediation & DEF & 6.1 & 0.4 & -0.39 & 52.3 \\
\hline SWI1992 & 0.735 & 0.68 & 368 & Appropriateness & Policy seeking & OFF & 0.9 & 1.2 & - & 49.7 \\
\hline SWI1997 & 0.81 & 0.87 & 543 & Constitutionality & $\begin{array}{l}\text { Popular initia- } \\
\text { tive }\end{array}$ & DEF & 1.5 & 0.4 & - & $(74.1)$ \\
\hline SWI2001 & 0.865 & 0.58 & 445 & Constitutionality & $\begin{array}{l}\text { Popular initia- } \\
\text { tive }\end{array}$ & DEF & -2.5 & -0.1 & - & $(76.8)$ \\
\hline
\end{tabular}

Treaty referendums $(n=16)$.

\begin{tabular}{lllllllllll}
\hline DEN1986 & 0.436 & 0.46 & 778 & Partisan & Policy seeking & OFF & 0.9 & -1.6 & 0.71 & 56.2 \\
\hline DEN1992 & 0.33 & 0.73 & 532 & Legisl. mandatory & Mandatory & OFF & 0.7 & 0.7 & 0.44 & 49.3 \\
\hline DEN1993 & 0.503 & 0.93 & 113 & Appropriateness & Policy seeking EU & OFF & -2.1 & 0.9 & 0.46 & 56.7 \\
\hline DEN1998 & 0.391 & 0.8 & 78 & Legisl. mandatory & Mandatory & OFF & -1 & -0.3 & 0.03 & 55.1 \\
\hline FRA1992 & 0.477 & 0.9 & 1568 & Partisan & Power reinforcing & OFF & 0.5 & 0.4 & 0.00 & 51.1 \\
\hline FRA2005 & 0.69 & 0.87 & 1077 & Partisan & $\begin{array}{l}\text { Power reinforcing / } \\
\text { domino }\end{array}$ & OFF & -0.7 & 0.4 & -0.16 & 45.3 \\
\hline IRL1987 & 0.488 & 0.88 & 77 & Judic. mandatory & Mandatory & OFF & 5.1 & 0.7 & 4.25 & 69.9 \\
\hline IRL1992 & 0.5 & 0.95 & 1072 & Constitutionality & Mandatory & OFF & 1.4 & -2.7 & 5.55 & 69.1 \\
\hline IRL1998 & 0.488 & 0.92 & 330 & Legisl. mandatory & Mandatory & OFF & -3.1 & -2.7 & 3.01 & 61.7 \\
\hline IRL2001 & 0.488 & 0.92 & 1442 & Constitutionality & Mandatory & OFF & -4 & -0.4 & 1.16 & 46.1 \\
\hline IRL2002 & 0.536 & 0.85 & 135 & Constitutionality & Mandatory & OFF & 0.3 & 0.5 & 1.39 & 62.9 \\
\hline IRL2008 & 0.518 & 0.91 & 364 & Constitutionality & Mandatory & OFF & -7.5 & 1.7 & 0.35 & 46.6 \\
\hline IRL2009 & 0.518 & 0.95 & 811 & Constitutionality & Mandatory & OFF & -3.4 & 5.6 & -0.03 & 67 \\
\hline LUX2005 & 0.633 & 0.92 & 344 & Partisan & Power reinforcing & OFF & 0.9 & 0.4 & 0.47 & 56.5 \\
\hline NET2005 & 0.52 & 0.85 & 736 & Appropriateness & $\begin{array}{l}\text { Parliamentary } \\
\text { initiative }\end{array}$ & DEF & -0.2 & 0.2 & -0.49 & 38.2 \\
\hline SPA2005 & 0.469 & 0.94 & 310 & Partisan & Power reinforcing & OFF & 0.3 & -1.9 & 0.66 & 76.7 \\
\hline
\end{tabular}


Policy referendums $(\mathrm{n}=18)$.

\begin{tabular}{lllllllllll}
\hline DEN2000 & 0.391 & 0.78 & 932 & Legisl. mandatory & Mandatory & OFF & 0.9 & -0.8 & 0.14 & 46.9 \\
\hline DEN2014 & 0.341 & 0.79 & 965 & Legisl. mandatory & Mandatory & OFF & 1.5 & -0.5 & -0.32 & 62.5 \\
\hline DEN2015 & 0.19 & 0.62 & 168 & Appropriateness & Parl. Empowerment & DEF & -0.1 & -0.3 & -0.29 & 46.9 \\
\hline FRA1972 & 0.791 & 0.79 & 1038 & Partisan & Power reinforcing & OFF & -0.8 & 0.1 & 0.18 & 68.3 \\
\hline GRC2015 & 0.54 & 0.65 & 160 & Partisan & Power reinforcing & OFF & 1 & -1.7 & 2.80 & $(61.3)$ \\
\hline HUN2016 & 0.668 & 0.78 & 876 & Partisan & Power reinforcing & OFF & -0.4 & -1.7 & 4.38 & 98.3 \\
\hline IRL2012 & 0.681 & 0.89 & 449 & Constitutionality & Mandatory & OFF & -0.5 & 0.1 & 0.47 & 60 \\
\hline ITA1989 & 0.598 & 1 & 691 & Partisan & Parl. empowerment & OFF & -0.8 & 0 & -0.02 & 88.1 \\
\hline NET2016 & 0.507 & 0.79 & 1248 & Constitutionality & Popular veto & DEF & -0.4 & -0.6 & -0.38 & 38.5 \\
\hline SWE2003 & 0.413 & 0.66 & 328 & Partisan & Mediation & DEF & -0.2 & 0.7 & -0.32 & 42 \\
\hline SWI1972 & 0.8 & 0.74 & 361 & Appropriateness & Policy seeking & OFF & -3.2 & 0.1 & - & 72.5 \\
\hline SWI2000 & 0.865 & 0.97 & 158 & Constitutionality & Popular veto & DEF & 2.3 & -0.7 & - & 67.2 \\
\hline SWI2005a & 0.58 & 0.69 & 543 & Constitutionality & Popular veto & DEF & 0.3 & -0.1 & - & 54.6 \\
\hline SWI2005b & 0.855 & 0.7 & 655 & Constitutionality & Popular veto & DEF & 0.3 & -0.1 & - & 56 \\
\hline SWI2006 & 0.855 & 0.7 & 1082 & Constitutionality & Popular veto & DEF & 1.1 & -0.4 & - & 53.4 \\
\hline SWI2009a & 0.835 & 0.78 & 60 & Constitutionality & Popular veto & DEF & -4.1 & 1.1 & - & 59.6 \\
\hline SWI2009b & 0.835 & 0.54 & 158 & Constitutionality & Popular veto & DEF & -4.1 & 1.1 & - & 50.1 \\
\hline SWI2014 & 0.575 & 0.7 & 788 & Constitutionality & Popular initiative & DEF & -1.2 & 0.3 & - & 49.7 \\
\hline
\end{tabular}

*In the year of accession, if no data are available for the referendum year itself.

**Data for Denmark 1982, which was a net recipient at the time, incl. Greenland. 
Table A4.2. Fuzzy data.

Membership referendums ( $\mathrm{n}=27)$.

\begin{tabular}{llllllll}
\hline CaseID & MAJ & ELI & ELE & OFF & ECD & REC & OUT \\
\hline AUS1994 & 1 & 0.67 & 0 & 0.67 & 1 & 0 & 0.83 \\
CRO2012 & 0.67 & 1 & 1 & 0.67 & 0 & 0.67 & 0.83 \\
CZE2003 & 0.67 & 0.67 & 0.67 & 0.67 & 0.67 & 0.67 & 0.83 \\
DEN1972 & 0 & 1 & 0.33 & 0.67 & 1 & 0.67 & 0.67 \\
EST2003 & 0.67 & 0.33 & 1 & 0.67 & 1 & 1 & 0.83 \\
FIN1994 & 0.67 & 0.67 & 0 & 0.33 & 1 & 0.33 & 0.67 \\
GBR1975 & 0.67 & 0.33 & 1 & 0.33 & 0 & 0.67 & 0.83 \\
GBR2016 & 0.33 & 0.33 & 0.33 & 0.33 & 0.67 & 0 & 0.33 \\
GRE1982 & 0.67 & 0.33 & 0 & 1 & 0 & 0.67 & 0.67 \\
HUN2003 & 0.67 & 1 & 0.67 & 0.67 & 0.67 & 0.67 & 1 \\
IRL1972 & 0.67 & 1 & 0 & 0.67 & 1 & 1 & 1 \\
LAT2003 & 0.67 & 1 & 0.67 & 0.67 & 1 & 1 & 0.83 \\
LIE1992 & 1 & 1 & 0 & 0.67 & 1 & 0 & 0.67 \\
LIE1995 & 1 & 1 & 0.33 & 0.67 & 1 & 0 & 0.67 \\
LIT2003 & 0.67 & 1 & 1 & 0.67 & 1 & 1 & 1 \\
MAL2003 & 0.67 & 0 & 0 & 1 & 0 & 0.67 & 0.67 \\
NOR1972 & 0.33 & 0 & 0 & 0.33 & 0.33 & 0 & 0.16 \\
NOR1994 & 0 & 0 & 0.33 & 0.33 & 1 & 0 & 0.16 \\
POL2003 & 0.67 & 0.67 & 0.33 & 0.33 & 1 & 0.67 & 0.83 \\
ROM2003 & 0 & 0.33 & 0 & 1 & 1 & 0.67 & 1 \\
SLK2003 & 0.67 & 1 & 1 & 0.33 & 1 & 0.67 & 1 \\
SLO2003 & 0.67 & 1 & 0 & 0.67 & 0.33 & 0.67 & 1 \\
SMR2013 & 0.67 & 0 & 0.67 & 0.33 & 1 & 0.33 & 0.67 \\
SWE1994 & 0.33 & 0 & 1 & 0.33 & 1 & 0 & 0.67 \\
SWI1992 & 1 & 0.33 & 0.33 & 1 & 0.33 & 0 & 0.33 \\
SWI1997 & 1 & 1 & 0.33 & 0.33 & 0.67 & 0 & 0.83 \\
SWI2001 & 1 & 0 & 0.33 & 0.33 & 0.33 & 0 & 0.83 \\
\hline & & & & & & & \\
SW & 0.67 & 1 & 1 \\
\hline
\end{tabular}


Treaty referendums $(\mathrm{n}=16)$.

\begin{tabular}{llllllll}
\hline CaSeID & MAJ & ELI & ELE & OFF & ECD & REC & OUT \\
\hline DEN1986 & 0 & 0 & 0 & 0.67 & 1 & 0.67 & 0.67 \\
DEN1992 & 0 & 0.33 & 0.33 & 0.67 & 0.33 & 0.67 & 0.33 \\
DEN1993 & 0.67 & 1 & 1 & 0.67 & 0 & 0.67 & 0.67 \\
DEN1998 & 0 & 0.67 & 1 & 0.67 & 0.67 & 0.67 & 0.67 \\
FRA1992 & 0.33 & 1 & 0 & 1 & 0.67 & 0.33 & 0.67 \\
FRA2005 & 1 & 1 & 0 & 0.67 & 0.33 & 0.33 & 0.16 \\
IRL1987 & 0.33 & 1 & 1 & 0.67 & 1 & 1 & 0.83 \\
IRL1992 & 0.33 & 1 & 0 & 0.67 & 1 & 1 & 0.83 \\
IRL1998 & 0.33 & 1 & 0.67 & 0.67 & 1 & 1 & 0.67 \\
IRL2001 & 0.33 & 1 & 0 & 0.67 & 0 & 1 & 0.16 \\
IRL2002 & 0.67 & 1 & 1 & 0.67 & 0.33 & 1 & 0.67 \\
IRL2008 & 0.67 & 1 & 0.33 & 0.67 & 0 & 0.67 & 0.16 \\
IRL2009 & 0.67 & 1 & 0 & 0.67 & 0 & 0.33 & 0.83 \\
LUX2005 & 0.67 & 1 & 0.33 & 1 & 0.67 & 0 & 0.67 \\
NET2005 & 0.67 & 1 & 0 & 0.33 & 0.33 & 0 & 0 \\
SPA2005 & 0.33 & 1 & 0.67 & 1 & 1 & 0.67 & 0.83 \\
\hline
\end{tabular}

Policy referendums $(\mathrm{n}=18)$.

\begin{tabular}{llllllll}
\hline CaseID & MAJ & ELI & ELE & OFF & ECD & REC & OUT \\
\hline DEN2000 & 0 & 0.67 & 0 & 0.67 & 1 & 0.67 & 0.16 \\
DEN2014 & 0 & 0.67 & 0 & 0.67 & 1 & 0 & 0.67 \\
DEN2015 & 0 & 0.33 & 1 & 0.33 & 0.67 & 0 & 0.16 \\
FRA1972 & 1 & 0.67 & 0 & 1 & 0.33 & 0.67 & 0.83 \\
GRC2015 & 0.67 & 0.33 & 1 & 1 & 1 & 1 & 0.67 \\
HUN2016 & 1 & 0.67 & 0 & 1 & 0.67 & 1 & 0.33 \\
IRL2012 & 1 & 1 & 0.33 & 0.67 & 0.33 & 0.67 & 0.67 \\
ITA1989 & 0.67 & 1 & 0 & 1 & 0.33 & 0.33 & 1 \\
NET2016 & 0.67 & 0.67 & 0 & 0.33 & 0.67 & 0 & 0 \\
SWE2003 & 0 & 0.33 & 0.67 & 0.33 & 0.33 & 0 & 0 \\
SWI1972 & 1 & 0.33 & 0.33 & 1 & 0 & 0 & 0.83 \\
SWI2000 & 1 & 1 & 1 & 0.33 & 1 & 0 & 0.83 \\
SWI2005a & 0.67 & 0.33 & 0.33 & 0.33 & 0.67 & 0 & 0.67 \\
SWI2005b & 1 & 0.33 & 0 & 0.33 & 0.67 & 0 & 0.67 \\
SWI2006 & 1 & 0.33 & 0 & 0.33 & 1 & 0 & 0.67 \\
SWI2009a & 1 & 0.67 & 1 & 0.33 & 0 & 0 & 0.67 \\
SWI2009b & 1 & 0.67 & 1 & 0.33 & 0 & 0 & 0.67 \\
SWI2014 & 0.67 & 0.33 & 0 & 0.33 & 0.33 & 0 & 0.33 \\
\hline
\end{tabular}


Table A4.3: Descriptive statistics of raw variables per referendum type.

Membership referendums ( $\mathrm{n}=27)$

\begin{tabular}{lrrrrrrr}
\hline Variable & Mean & $\begin{array}{r}\text { Standard } \\
\text { deviation }\end{array}$ & Skew & Median & Minimum & Maximum & Range \\
\hline MAJ & 0,59 & 0,17 & 0,94 & 0,54 & 0,29 & 1,00 & 0,71 \\
ELI & 0,77 & 0,18 & $-0,16$ & 0,78 & 0,43 & 1,00 & 0,57 \\
ELE & 583,19 & 436,56 & 0,81 & 441,00 & 30,00 & 1644,00 & 1614,00 \\
OFF & 0,58 & 0,24 & 0,36 & 0,67 & 0,33 & 1,00 & 0,67 \\
ECO & 0,72 & 2,30 & $-0,15$ & 0,90 & $-5,10$ & 6,10 & 11,20 \\
UNE & $-0,06$ & 0,88 & 0,17 & 0,00 & $-1,50$ & 1,70 & 3,20 \\
REC & 0,46 & 0,77 & 1,26 & 0,24 & $-0,46$ & 2,66 & 3,12 \\
OUT & 66,76 & 14,97 & 0,28 & 66,70 & 46,50 & 92,50 & 46,00 \\
\hline
\end{tabular}

Treaty referendums ( $\mathrm{n}=16)$

\begin{tabular}{lrrrrrrr}
\hline Variable & Mean & $\begin{array}{r}\text { Standard } \\
\text { deviation }\end{array}$ & Skew & Median & Minimum & Maximum & Range \\
\hline MAJ & 0,50 & 0,08 & 0,34 & 0,49 & 0,33 & 0,69 & 0,36 \\
ELI & 0,86 & 0,12 & $-2,20$ & 0,91 & 0,46 & 0,95 & 0,49 \\
ELE & 610,44 & 481,08 & 0,59 & 448,00 & 77,00 & 1568,00 & 1491,00 \\
OFF & 0,71 & 0,17 & 0,23 & 0,67 & 0,33 & 1,00 & 0,67 \\
ECO & $-0,74$ & 2,84 & $-0,41$ & 0,05 & $-7,50$ & 5,10 & 12,60 \\
UNE & 0,12 & 1,96 & 0,92 & 0,40 & $-2,70$ & 5,60 & 8,30 \\
REC & 1,11 & 1,70 & 1,44 & 0,47 & $-0,49$ & 5,55 & 6,04 \\
OUT & 56,78 & 10,56 & 0,14 & 56,35 & 38,20 & 76,70 & 38,50 \\
\hline
\end{tabular}

Policy referendums $(\mathrm{n}=18)$

\begin{tabular}{lrrrrrrr}
\hline Variable & Mean & $\begin{array}{r}\text { Standard } \\
\text { deviation }\end{array}$ & Skew & Median & Minimum & Maximum & Range \\
\hline MAJ & 0,63 & 0,20 & $-0,46$ & 0,63 & 0,19 & 0,87 & 0,68 \\
ELI & 0,75 & 0,12 & 0,46 & 0,76 & 0,54 & 1,00 & 0,46 \\
ELE & 592,22 & 378,00 & 0,11 & 599,00 & 60,00 & 1248,00 & 1188,00 \\
OFF & 0,57 & 0,30 & 0,51 & 0,33 & 0,33 & 1,00 & 0,67 \\
ECO & $-0,47$ & 1,78 & $-0,76$ & $-0,30$ & $-4,10$ & 2,30 & 6,40 \\
UNE & $-0,19$ & 0,77 & $-0,26$ & $-0,10$ & $-1,70$ & 1,10 & 2,80 \\
REC & 0,37 & 1,22 & 2,36 & 0,00 & $-0,38$ & 4,38 & 4,76 \\
OUT & 61,05 & 14,32 & 1,09 & 59,80 & 42,00 & 98,30 & 56,30 \\
\hline
\end{tabular}




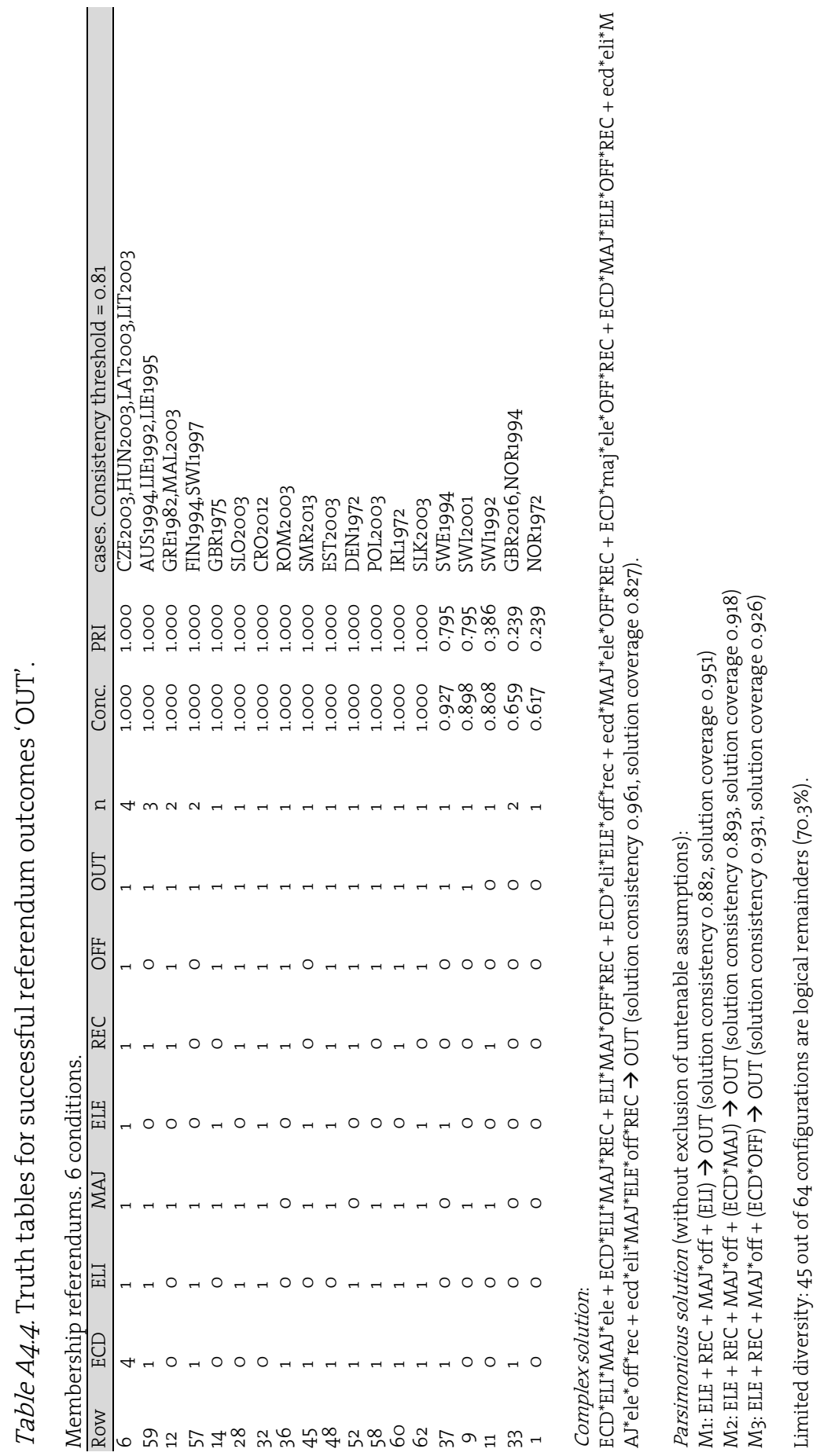



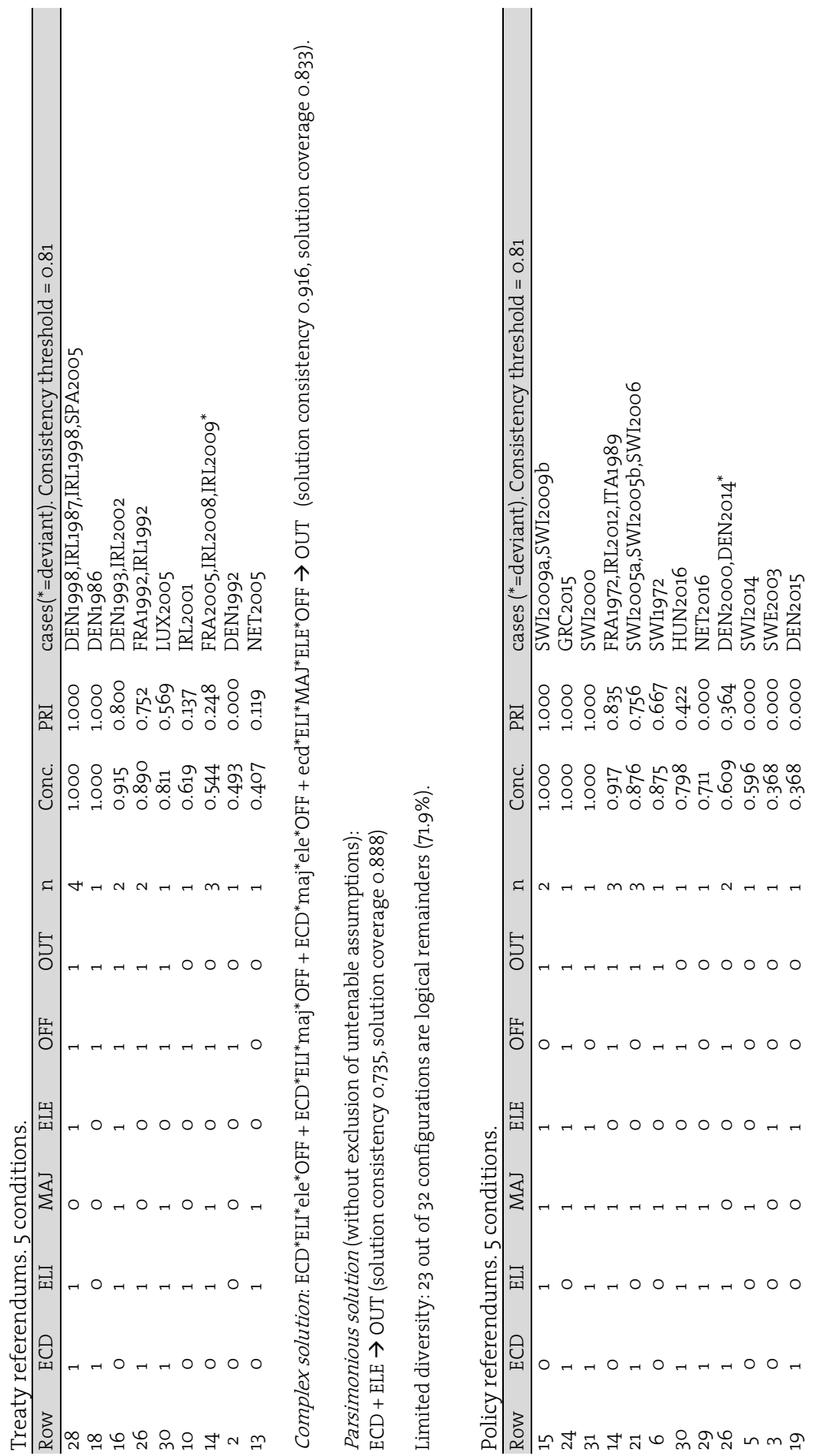

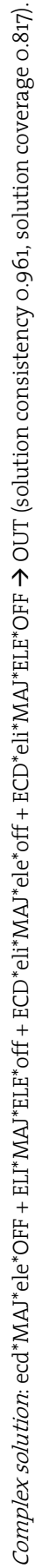

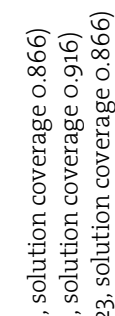
का $\because \infty \infty$ \%

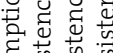

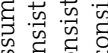

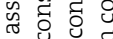
동 동.

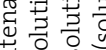
‡ 㟧占宫吕 돗 筞定焉 e $\sum_{*}^{*}=*$ $\pm=*$

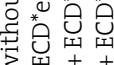
运界+ 도법

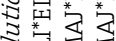
舀主 告点吉 㟔 है "ृ पु " ๙ 


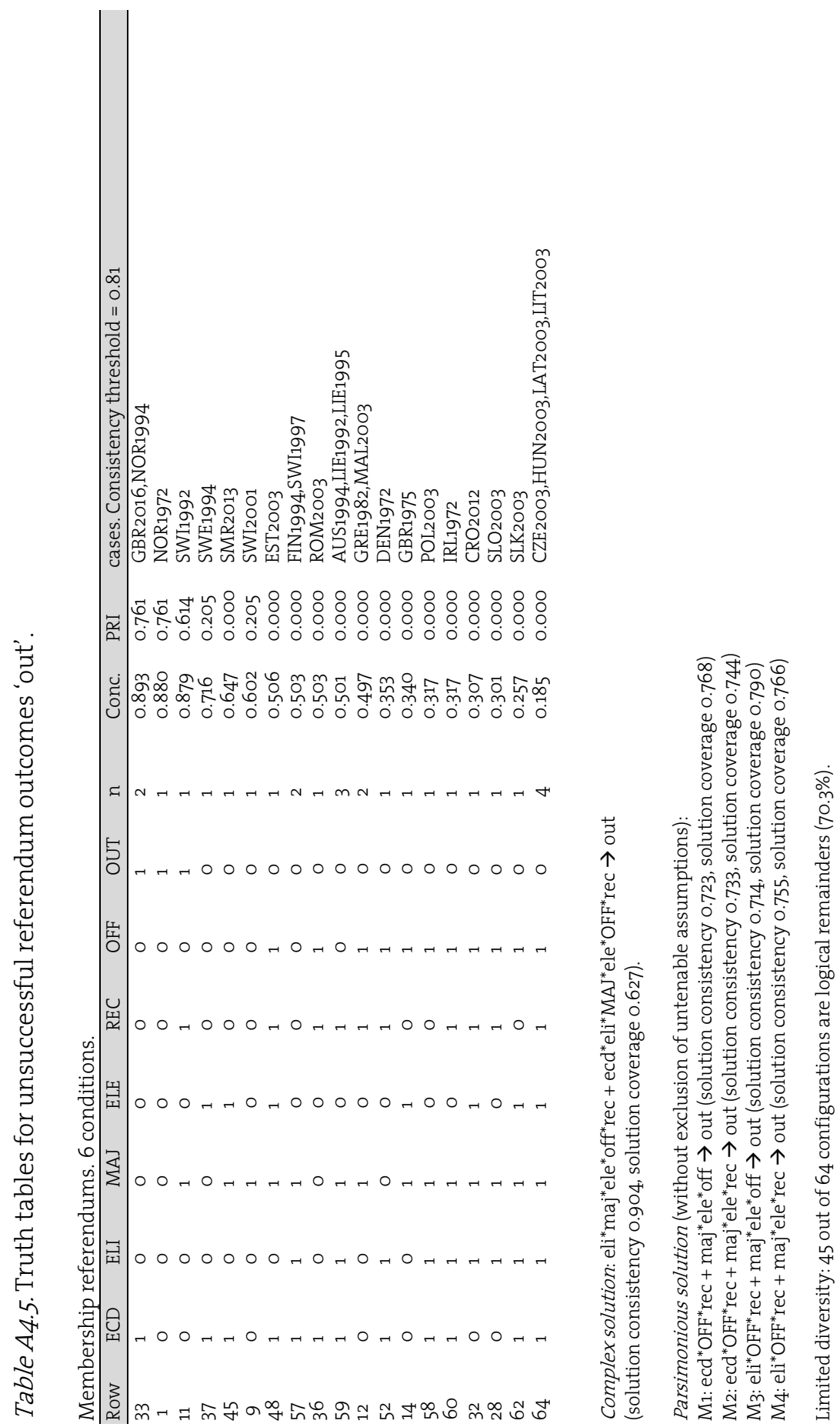



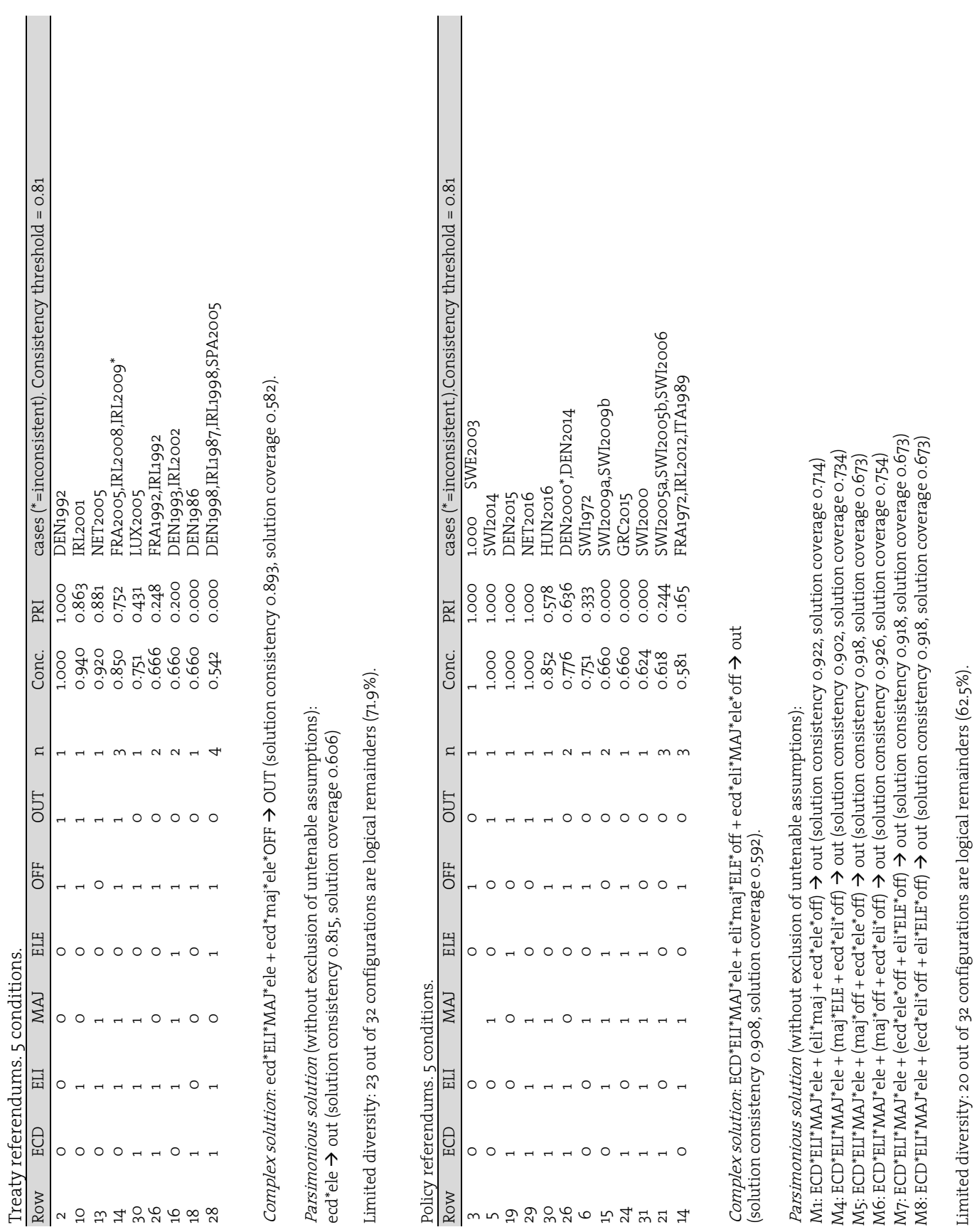
Table A4.6. Simplifying assumptions for analysis of successful referendum outcomes 'OUT'.

Membership referendums. 6 conditions

\begin{tabular}{|c|c|c|c|c|c|c|c|}
\hline & ECD & ELI & MAJ & ELE & OFF & REC & $\begin{array}{l}\text { Easy counterfactual } \\
\text { (used for intermediate solution)? }\end{array}$ \\
\hline 2 & 0 & 0 & 0 & 0 & 0 & 1 & - \\
\hline 4 & 0 & 0 & 0 & 0 & 1 & 1 & - \\
\hline 5 & 0 & 0 & 0 & 1 & 0 & 0 & - \\
\hline 6 & 0 & 0 & 0 & 1 & 0 & 1 & - \\
\hline 7 & 0 & 0 & 0 & 1 & 1 & 0 & - \\
\hline 8 & 0 & 0 & 0 & 1 & 1 & 1 & - \\
\hline 10 & 0 & 0 & 1 & o & 0 & 1 & $X$ \\
\hline 13 & 0 & 0 & 1 & 1 & 0 & 0 & $X$ \\
\hline 15 & 0 & 0 & 1 & 1 & 1 & 0 & - \\
\hline 16 & 0 & 0 & 1 & 1 & 1 & 1 & - \\
\hline 17 & 0 & 1 & 0 & 0 & 0 & 0 & - \\
\hline 18 & 0 & 1 & o & 0 & 0 & 1 & - \\
\hline 19 & 0 & 1 & o & o & 1 & 0 & - \\
\hline 20 & 0 & 1 & o & o & 1 & 1 & - \\
\hline 21 & 0 & 1 & o & 1 & 0 & 0 & - \\
\hline 22 & 0 & 1 & o & 1 & 0 & 1 & - \\
\hline 23 & 0 & 1 & o & 1 & 1 & 0 & - \\
\hline 24 & 0 & 1 & 0 & 1 & 1 & 1 & - \\
\hline 25 & 0 & 1 & 1 & 0 & 0 & 0 & $X$ \\
\hline 26 & 0 & 1 & 1 & o & 0 & 1 & $X$ \\
\hline 27 & 0 & 1 & 1 & o & 1 & 0 & - \\
\hline 29 & 0 & 1 & 1 & 1 & 0 & 0 & $X$ \\
\hline 30 & 0 & 1 & 1 & 1 & 0 & 1 & $\mathrm{X}$ \\
\hline 31 & 0 & 1 & 1 & 1 & 1 & 0 & - \\
\hline 34 & 1 & 0 & 0 & o & 0 & 1 & - \\
\hline 38 & 1 & 0 & 0 & 1 & 0 & 1 & $\mathrm{X}$ \\
\hline 39 & 1 & 0 & o & 1 & 1 & 0 & $X$ \\
\hline 40 & 1 & 0 & o & 1 & 1 & 1 & $X$ \\
\hline 41 & 1 & $\mathrm{O}$ & 1 & 0 & 0 & $\mathrm{O}$ & $X$ \\
\hline 42 & 1 & 0 & 1 & 0 & 0 & 1 & $\mathrm{X}$ \\
\hline 44 & 1 & 0 & 1 & o & 1 & 1 & $\mathrm{X}$ \\
\hline 46 & 1 & 0 & 1 & 1 & 0 & 1 & $\mathrm{X}$ \\
\hline 47 & 1 & 0 & 1 & 1 & 1 & 0 & $X$ \\
\hline 49 & 1 & 1 & o & o & 0 & 0 & - \\
\hline 50 & 1 & 1 & o & 0 & 0 & 1 & - \\
\hline 51 & 1 & 1 & o & 0 & 1 & 0 & - \\
\hline 53 & 1 & 1 & o & 1 & 0 & 0 & $\mathrm{X}$ \\
\hline 54 & 1 & 1 & o & 1 & 0 & 1 & $X$ \\
\hline 55 & 1 & 1 & 0 & 1 & 1 & 0 & - \\
\hline 56 & 1 & 1 & o & 1 & 1 & 1 & $X$ \\
\hline 61 & 1 & 1 & 1 & 1 & 0 & 0 & $X$ \\
\hline 63 & 1 & 1 & 1 & 1 & 1 & 0 & $X$ \\
\hline
\end{tabular}


Treaty referendums. 5 conditions

\begin{tabular}{lllllll}
\hline & ECD & ELI & MAJ & ELE & OFF Easy counterfactual (used for intermediate solution)? \\
\hline 3 & 0 & 0 & 0 & 1 & 0 & - \\
4 & 0 & 0 & 0 & 1 & 1 & - \\
7 & 0 & 0 & 1 & 1 & 0 & - \\
8 & 0 & 0 & 1 & 1 & 1 & - \\
11 & 0 & 1 & 0 & 1 & 0 & - \\
12 & 0 & 1 & 0 & 1 & 1 & - \\
15 & 0 & 1 & 1 & 1 & 0 & - \\
17 & 1 & 0 & 0 & 0 & 0 & - \\
19 & 1 & 0 & 0 & 1 & 0 & - \\
20 & 1 & 0 & 0 & 1 & 1 & X \\
21 & 1 & 0 & 1 & 0 & 0 & - \\
22 & 1 & 0 & 1 & 0 & 1 & X \\
23 & 1 & 0 & 1 & 1 & 0 & - \\
24 & 1 & 0 & 1 & 1 & 1 & X \\
25 & 1 & 1 & 0 & 0 & 0 & - \\
27 & 1 & 1 & 0 & 1 & 0 & - \\
29 & 1 & 1 & 1 & 0 & 0 & - \\
31 & 1 & 1 & 1 & 1 & 0 & - \\
32 & 1 & 1 & 1 & 1 & 1 & $X$ \\
\hline
\end{tabular}

Policy referendums. 5 conditions

\begin{tabular}{lllllll}
\hline & ECD & ELI & MAJ & ELE & OFF & Easy counterfactual (used for intermediate solution)? \\
\hline 2 & 0 & 0 & 0 & 0 & 1 & - \\
4 & 0 & 0 & 0 & 1 & 1 & - \\
8 & 0 & 0 & 1 & 1 & 1 & X \\
10 & 0 & 1 & 0 & 0 & 1 & - \\
11 & 0 & 1 & 0 & 1 & 0 & - \\
12 & 0 & 1 & 0 & 1 & 1 & - \\
16 & 0 & 1 & 1 & 1 & 1 & $\mathrm{X}$ \\
22 & 1 & 0 & 1 & 0 & 1 & $\mathrm{X}$ \\
23 & 1 & 0 & 1 & 1 & 0 & $\mathrm{X}$ \\
27 & 1 & 1 & 0 & 1 & 0 & - \\
28 & 1 & 1 & 0 & 1 & 1 & - \\
32 & 1 & 1 & 1 & 1 & 1 & $\mathrm{X}$ \\
\hline
\end{tabular}

Table A4.7. Simplifying assumptions for analysis of unsuccessful referendum outcomes 'out'.

Membership referendums. 6 conditions

\begin{tabular}{llllllll}
\hline & ECD & ELI & MAJ & ELE & OFF & REC & $\begin{array}{l}\text { Easy counterfactual } \\
\text { (used for intermediate solution)? }\end{array}$ \\
\hline 2 & 0 & 0 & 0 & 0 & 0 & 1 & - \\
3 & 0 & 0 & 0 & 0 & 1 & 0 & $\mathrm{X}$ \\
7 & 0 & 0 & 0 & 1 & 1 & 0 & - \\
15 & 0 & 0 & 1 & 1 & 1 & 0 & - \\
17 & 0 & 1 & 0 & 0 & 0 & 0 & - \\
18 & 0 & 1 & 0 & 0 & 0 & 1 & - \\
19 & 0 & 1 & 0 & 0 & 1 & 0 & - \\
23 & 0 & 1 & 0 & 1 & 1 & 0 & - \\
27 & 0 & 1 & 1 & 0 & 1 & 0 & - \\
31 & 0 & 1 & 1 & 1 & 1 & 0 & - \\
34 & 1 & 0 & 0 & 0 & 0 & 1 & - \\
49 & 1 & 1 & 0 & 0 & 0 & 0 & - \\
50 & 1 & 1 & 0 & 0 & 0 & 1 & - \\
\hline
\end{tabular}


Treaty referendums. 5 conditions

\begin{tabular}{|c|c|c|c|c|c|c|}
\hline & $\mathrm{ECD}$ & ELI & MAJ & ELE & OFF & Easy counterfactual (used for intermediate solution)? \\
\hline 1 & $\mathrm{O}$ & $\mathrm{O}$ & $\mathrm{O}$ & o & $\mathrm{O}$ & $\mathrm{X}$ \\
\hline 5 & 0 & 0 & 1 & o & 0 & $\mathrm{X}$ \\
\hline 6 & 0 & o & 1 & o & 1 & $\mathrm{X}$ \\
\hline 9 & $\mathrm{O}$ & 1 & $\mathrm{O}$ & o & $\mathrm{O}$ & $\mathrm{X}$ \\
\hline
\end{tabular}

Policy referendums. 5 conditions

\begin{tabular}{llllllc}
\hline & ECD & ELI & MAJ & ELE & OFF & Easy counterfactual (used for intermediate solution)? \\
\hline 1 & 0 & 0 & 0 & 0 & 0 & X \\
2 & 0 & 0 & 0 & 0 & 1 & - \\
4 & 0 & 0 & 0 & 1 & 1 & - \\
9 & 0 & 1 & 0 & 0 & 0 & - \\
13 & 0 & 1 & 1 & 0 & 0 & X \\
17 & 1 & 0 & 0 & 0 & 0 & - \\
18 & 1 & 0 & 0 & 0 & 1 & - \\
20 & 1 & 0 & 0 & 1 & 1 & - \\
\hline
\end{tabular}

Table A4.8. Analysis of necessity for successful outcome 'OUT' and unsuccessful outcome 'out'.

Membership referendums

\begin{tabular}{|l|lll|lll|}
\hline Condition & \multicolumn{2}{l|}{ Successful Outcome (OUT) } & \multicolumn{4}{l|}{ Failed Outcome (out) } \\
(PRESENCE/absence) & Consistency & Coverage & RoN & Consistency & Coverage & RoN \\
\hline MAJ & 0.759 & 0.882 & 0.832 & 0.719 & 0.303 & 0.456 \\
ELI & 0.715 & 0.904 & 0.883 & 0.510 & 0.234 & 0.486 \\
ELE & 0.520 & 0.911 & 0.939 & 0.510 & 0.324 & 0.672 \\
OFF & 0.707 & 0.893 & 0.872 & 0.811 & 0.372 & 0.535 \\
ECD & 0.757 & 0.789 & 0.666 & 0.743 & 0.281 & 0.369 \\
REC & 0.590 & 0.972 & 0.978 & 0.371 & 0.222 & 0.615 \\
& & & & & & 0.781 \\
maj & 0.401 & 0.797 & 0.894 & 0.720 & 0.520 & 0.735 \\
eli & 0.395 & 0.690 & 0.816 & 0.791 & 0.502 & 0.544 \\
ele & 0.503 & 0.776 & 0.763 & 0.860 & 0.394 & 0.730 \\
off & 0.503 & 0.880 & 0.920 & 0.768 & 0.487 & 0.798 \\
ecd & 0.310 & 0.769 & 0.911 & 0.442 & 0.397 & 0.597 \\
rec & 0.344 & 0.584 & 0.760 & 0.953 & 0.458 & \\
\hline
\end{tabular}

Treaty referendums

\begin{tabular}{|l|lll|lll|}
\hline Condition & \multicolumn{4}{l|}{ Successful Outcome (OUT) } & \multicolumn{3}{l|}{ Failed Outcome (out) } \\
(PRESENCE/absence) & Consistency & Coverage & RoN & Consistency & Coverage & RoN \\
\hline MAJ & 0.545 & 0.687 & 0.804 & 0.674 & 0.691 & 0.806 \\
ELI & 0.924 & 0.582 & 0.255 & 0.907 & 0.465 & 0.211 \\
ELE & 0.567 & 0.790 & 0.879 & 0.369 & 0.419 & 0.724 \\
OFF & 0.946 & 0.734 & 0.604 & 0.836 & 0.528 & 0.468 \\
ECD & 0.755 & 0.800 & 0.821 & 0.485 & 0.418 & 0.613 \\
REC & 0.811 & 0.714 & 0.677 & 0.720 & 0.516 & 0.553 \\
& & & & & & 0.636 \\
maj & 0.755 & 0.740 & 0.749 & 0.695 & 0.554 & 0.954 \\
eli & 0.151 & 0.665 & 0.954 & 0.185 & 0.665 & 0.624 \\
ele & 0.583 & 0.532 & 0.583 & 0.815 & 0.605 & 0.959 \\
off & 0.391 & 0.745 & 0.906 & 0.578 & 0.896 & 0.794 \\
ecd & 0.450 & 0.518 & 0.692 & 0.767 & 0.718 & 0.857 \\
rec & 0.451 & 0.664 & 0.833 & 0.602 & 0.721 & \\
\hline
\end{tabular}


Policy referendums

\begin{tabular}{|l|lll|lll|}
\hline Condition & \multicolumn{4}{|l|}{ Successful Outcome (OUT) } & \multicolumn{3}{l|}{ Failed Outcome (out) } \\
(PRESENCE/absence) & Consistency & Coverage & RoN & Consistency & Coverage & RoN \\
\hline MAJ & 0.866 & 0.689 & 0.595 & 0.591 & 0.391 & 0.429 \\
ELI & 0.795 & 0.756 & 0.753 & 0.753 & 0.595 & 0.647 \\
OFF & 0.406 & 0.599 & 0.809 & 0.428 & 0.526 & 0.782 \\
ECD & 0.776 & 0.740 & 0.742 & 0.711 & 0.564 & 0.631 \\
REC & 0.626 & 0.615 & 0.675 & 0.714 & 0.583 & 0.657 \\
& 0.288 & 0.625 & 0.900 & 0.266 & 0.500 & 0.863 \\
maj & & & & & & 0.903 \\
eli & 0.235 & 0.409 & 0.787 & 0.530 & 0.766 & 0.836 \\
ele & 0.575 & 0.737 & 0.836 & 0.692 & 0.737 & 0.533 \\
off & 0.679 & 0.588 & 0.588 & 0.673 & 0.485 & 0.824 \\
ecd & 0.542 & 0.693 & 0.814 & 0.672 & 0.714 & 0.731 \\
rec & 0.576 & 0.708 & 0.810 & 0.529 & 0.540 & 0.383 \\
\hline
\end{tabular}

Bold: Condition passes consistency threshold of 0.9. A consistent necessary condition is deemed trivial if coverage is below 0.6 and the RoN value is below 0.5 . 


\section{Appendix Ch. 5: Uniquely typical cases}

For membership referendums, the OCA provided five solution terms. The first term (ECD*ELE) provides no uniquely typical cases. Two jointly typical cases in the upper-right corner are the membership referendums in Lithuania and Slovakia. The second term (MAJ*off) provides the Swiss 2001 referendum as most uniquely typical case with a distance score of 0.24 to the diagonal, while the third term (MAJ*REC) provides both referendums of Greenland 1982 and Malta 2003 with a distance of o (the other two uniquely typical cases have a larger distance score: $\left.\mathrm{CRO}_{2012}=0.24, \mathrm{SLO}_{2003}=0.49\right)$. The fourth term $\left(\mathrm{ECD}^{*} \mathrm{ELI}^{*} \mathrm{MAJ}\right)$ reveals Austria's 1994 referendum (distance $=0$ ) and the fifth path $\left(E C D^{*} R E C^{*} O F F\right)$ discloses the Danish 1972 referendum (distance $=0$ ).

Table A5.1. Membership referendums

\begin{tabular}{|c|c|c|c|c|}
\hline case & term & mem & OUT & distance to diagonal \\
\hline 7 SWI2001 & MAJ*off (2) & 0.67 & 0.83 & 0.2388060 \\
\hline 52 GRE1982 & $M A J^{*} \operatorname{REC}(3)$ & 0.67 & 0.67 & 0.0000000 \\
\hline 10 MAL2OO3 & MAJ*REC (3) & 0.67 & 0.67 & 0.0000000 \\
\hline $111 \mathrm{CRO}_{2012}$ & MAJ*REC (3) & 0.67 & 0.83 & 0.2388060 \\
\hline $13 \mathrm{SLO}_{2003}$ & MAJ*REC (3) & 0.67 & 1.00 & 0.4925373 \\
\hline 112 AUS1994 & ECD*ELI*MAJ (4) & 0.67 & 0.83 & 0.2388060 \\
\hline 24 DEN1972 & ECD*REC*OFF (5) & 0.67 & 0.67 & 0.0000000 \\
\hline $82 \mathrm{ROM}_{2003}$ & ECD*REC*OFF (5) & 0.67 & 1.00 & 0.4925373 \\
\hline
\end{tabular}

For Treaty referendums, the cases that are on the main diagonal, are the most 'uniquely' typical cases, all with a distance score of o. These are 5 cases for the first term (ECD*OFF) and both two cases of the second term (ELI*MAJ*ELE*OFF).

Table A5.2. Treaty referendums

\begin{tabular}{|c|c|c|c|c|}
\hline case & term & mem & OUT & distance to diagonal \\
\hline 7 SWI2001 & MAJ*off (2) & 0.67 & 0.83 & 0.2388060 \\
\hline 52 GRE1982 & $M A{ }^{*} \mathrm{REC}(3)$ & 0.67 & 0.67 & 0.0000000 \\
\hline 10 MAL2OO3 & $M A J^{*} R E C(3)$ & 0.67 & 0.67 & 0.0000000 \\
\hline $111 \mathrm{CRO}_{2012}$ & $M A{ }^{*} R E C(3)$ & 0.67 & 0.83 & 0.2388060 \\
\hline $13 \mathrm{SLO}_{2003}$ & $\mathrm{MAJ}^{*} \mathrm{REC}(3)$ & 0.67 & 1.00 & 0.4925373 \\
\hline 112 AUS1994 & ECD*ELI*MAJ (4) & 0.67 & 0.83 & 0.2388060 \\
\hline 24 DEN1972 & ECD*REC ${ }^{*} \mathrm{OFF}(5)$ & 0.67 & 0.67 & 0.0000000 \\
\hline $82 \mathrm{ROM}_{20 O 3}$ & $\mathrm{ECD}^{*} \mathrm{REC}^{*} \mathrm{OFF}(5)$ & 0.67 & 1.00 & 0.4925373 \\
\hline
\end{tabular}

The most typical unique cases for Policy referendums are evenly easily able to identify, since all three solution terms have some cases placed on the main diagonal. For term 1 (ECD*eli*MAJ), the Greek 2015, and Swiss 2005a+b and 2006 referendums are most typical, for term 2 (ecd*MAJ*OFF) the Irish 2012 referendum, and for term 3 (ELI*MAJ*ELE) the Swiss $2009 a+b$ referendums. 
Table A5.3. Policy referendums

\begin{tabular}{lllll}
\hline case & term & mem & OUT & distance to diagonal \\
\hline 1 GRC2015 & ECD*eli*MAJ (1) & 0.67 & 0.67 & 0.000000 \\
2 SWI2005a & ECD*eli*MAJ (1) & 0.67 & 0.67 & 0.000000 \\
3 SWI2005b & ECD*eli*MAJ (1) & 0.67 & 0.67 & 0.000000 \\
4 SWI2006 & ECD*eli*MAJ (1) & 0.67 & 0.67 & 0.000000 \\
21 IRL2012 & ecd*MAJ*OFF (2) & 0.67 & 0.67 & 0.000000 \\
11 FRA1972 & ecd*MAJ*OFF (2) & 0.67 & 0.83 & 0.000000 \\
31 ITA1989 & ecd*MAJ*OFF (2) & 0.67 & 1.00 & 0.000000 \\
12 SWI2009a & ELI*MAJ*EL (3) & 0.67 & 0.67 & 0.000000 \\
22 SWI2009b & ELI*MAJ*LE (3) & 0.67 & 0.67 & 0.000000 \\
\hline
\end{tabular}




\section{Biography}

Joost van den Akker (1984) holds a master's degree (MA) in Analysing Europe/Europastudien from Maastricht University/RWTH Aachen University (2008) and a master's degree in European Law School (LLM) from Maastricht University (2010). In 2012 he started his PhD research at the Public Administration department of the faculty of Behavioural, Management and Social sciences at the University of Twente, supervised by Prof. Dr. Kees Aarts, Dr. Henk van der Kolk and Dr. Eric van de Luijtgaarden. In 2015 he received a grant from the Netherlands Organization for Scientific Research (NWO) to support his research.

Joost van den Akker worked as a lecturer in European Studies at Zuyd University of Applied Sciences in Maastricht and as a member the research group Law in Europe from 2009 until 2018. In 2008 he worked as a trainee account officer at the European Parliament's Information Office in The Hague.

In 2017, Joost van den Akker contributed to the study "Referendums on EU matters", commissioned by the European Parliament at request of the Committee on Constitutional Affairs: "The Netherlands: The Dutch EU referendums on the Constitutional Treaty (2005) and the EU-Ukraine Association Agreement (2016)." Commissioned by the City of Maastricht, in 2006-2007 he wrote the jubilee book "Maastricht the treaty" on the occasion of the 15th anniversary of the Maastricht Treaty. 




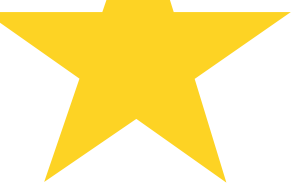

Referendums on European integration play a prominent role in the decisionmaking processes in current European democracies. Between 1972 and 2016, 61 EU-related referendums took place across 28 countries. In his dissertation, Joost van den Akker (1984) investigates under which conditions governments win such EU-related

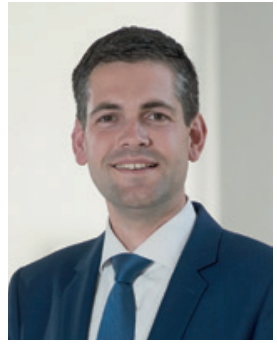
referendums. The fact that the government won in 46 cases demonstrates that overall governments have been quite successful in securing popular support for their EU policies.

The study locates the EU-related referendum in the historical perspective of referendums in Europe after the French revolution. It develops a model to explain the current potential and practice of EUrelated referendums in European democracies. The most prominent contribution lies in explaining the referendum result by politicalinstitutional and socio-economic conditions at the aggregate level. It is argued that a unified majority government and economic development are the main drivers for winning referendums. If the economy is deteriorating, however, the government only wins if it is only recently in office and backed by a wide consensus among elites. The dissertation explains why EU-related referendums are held, under which conditions governments win or lose them, and how governments cope with inconvenient outcomes. In this way, it contributes to the strategies which governments can deploy to win a referendum, or to deal best with a referendum defeat.
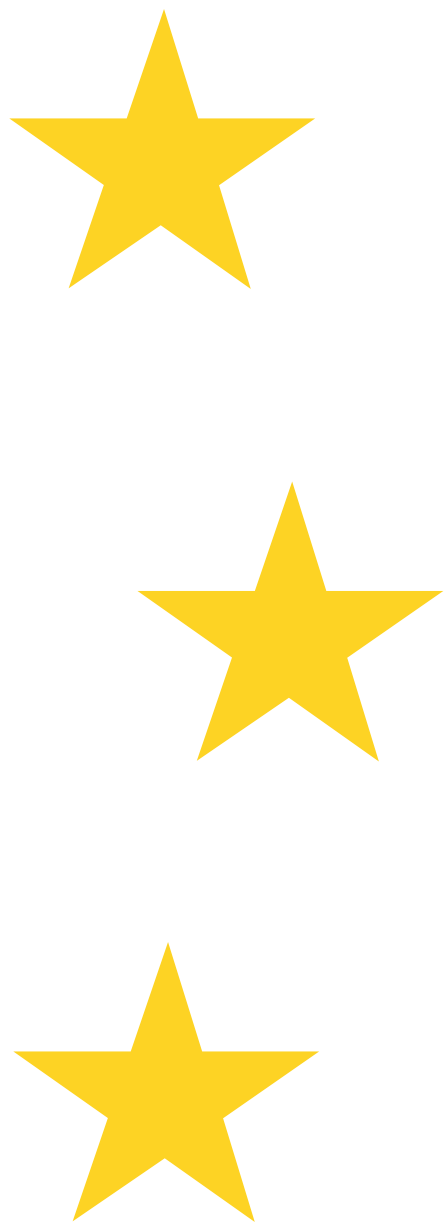

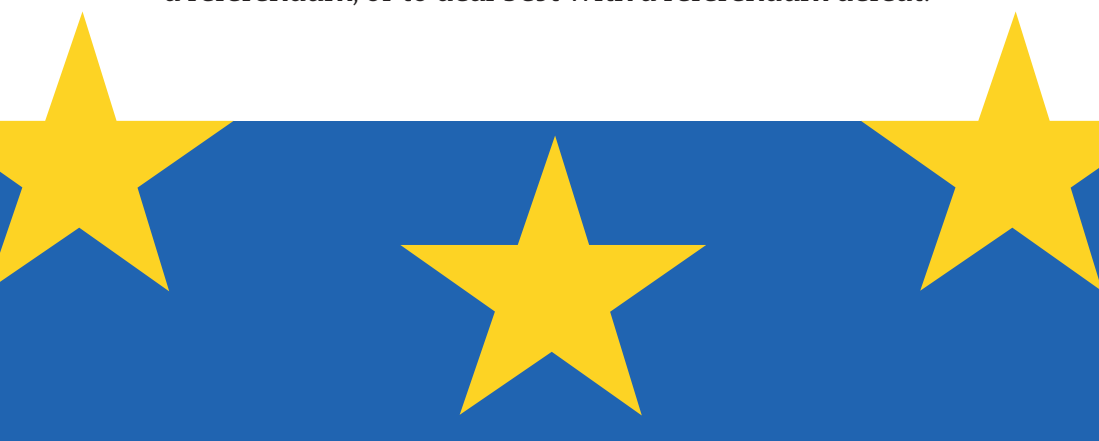

